Supporting Information for

\title{
Photocatalytic Oxidation of Lignin Model Systems by Merging Visible-Light Photoredox and Palladium Catalysis
}

Markus D. Kärkäs, † Irene Bosque, † Bryan S. Matsuura, + and Corey R. J. Stephenson +*

† Department of Chemistry, University of Michigan, Ann Arbor, Michigan 48109, United States

*Email: crjsteph@umich.edu 


\section{Table of Contents}

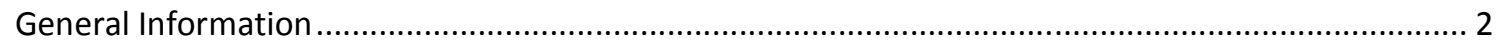

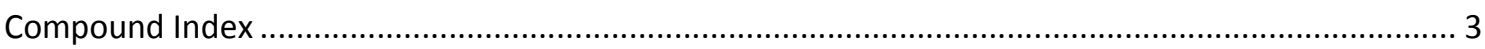

Representative Procedure for Oxidation of Lignin Model Systems ..................................................... 5

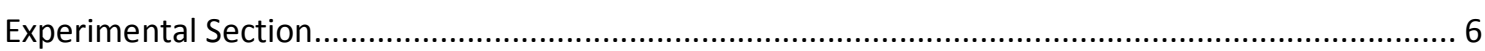

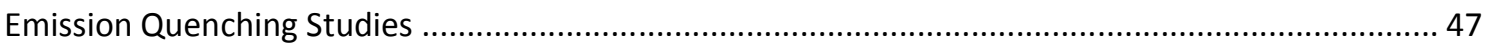

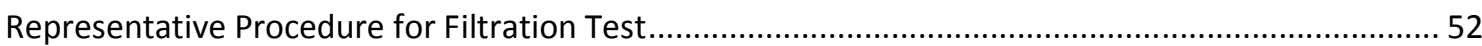

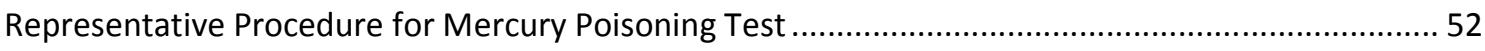

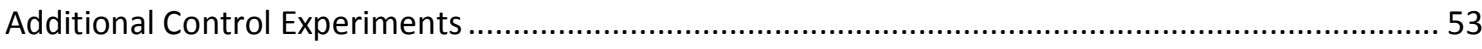

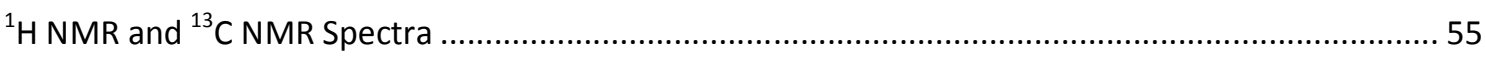

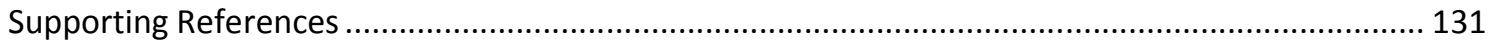




\section{General Information}

Chemicals were either used as received or purified according to the procedures outlined in Purification of Common Laboratory Chemicals. Thin-layer chromatography (TLC) analysis of reaction mixtures was performed using Merck silica gel 60 F254 TLC plates and visualized by a dual short wave/long wave UV lamp. Column flash chromatography was performed using 230-400 mesh silica gel.

Nuclear magnetic resonance (NMR) spectra were recorded using an internal deuterium lock on Varian MR400, Varian Inova 500 and Varian Vnmrs 700 spectrometers. ${ }^{1} \mathrm{H}$ - and ${ }^{13} \mathrm{C}$ NMR chemical shifts are reported in ppm and referenced to the residual protic solvent signal $\left(\mathrm{CHCl}_{3}: \delta \mathrm{H}=7.26 \mathrm{ppm}\right.$ and $\delta C=77.16$ ppm; acetone: $\delta H=2.05$ and $\delta C=29.84 ;$ DMSO: $\delta H=2.50$ and $\delta C=39.52 \mathrm{ppm}$ ). Multiplicities are reported using the following abbreviations: $s=\operatorname{singlet}, d=$ doublet, $t=$ triplet, $q=$ quartet, quint $=$ quintet, $\mathrm{m}=$ multiplet, $\mathrm{br}=$ broad resonance, $\mathrm{dd}=$ doublet of doublet, $\mathrm{dt}=$ doublet of triplet, etc. High-resolution mass spectra (ESI) were recorded at the Mass Spectrometry Facility at the Department of Chemistry of the University of Michigan in Ann Arbor, MI, on a Micromass AutoSpec Ultima Magnetic Sector mass spectrometer using electrospray ionization (ESI), positive ion mode. 


\section{Compound Index}

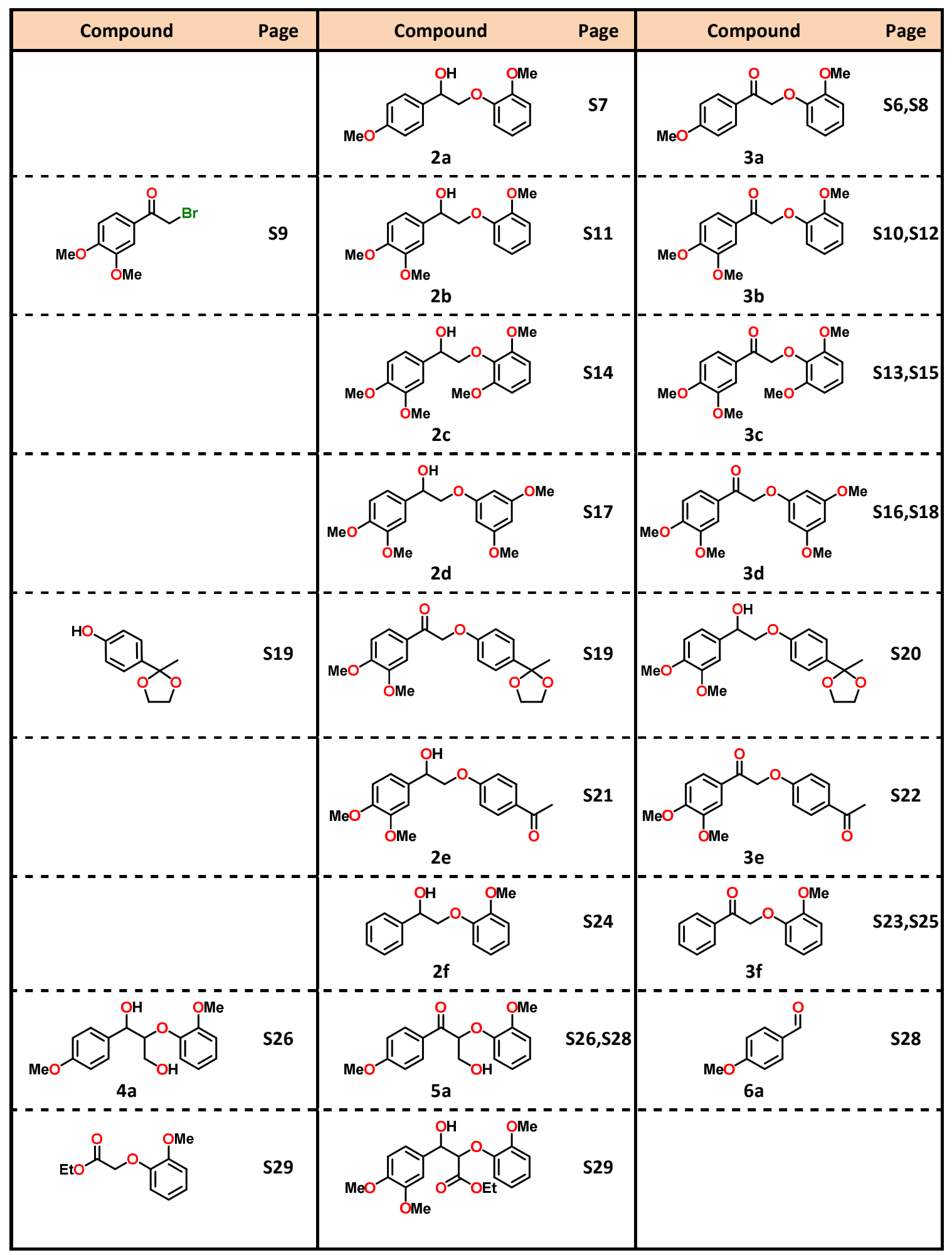




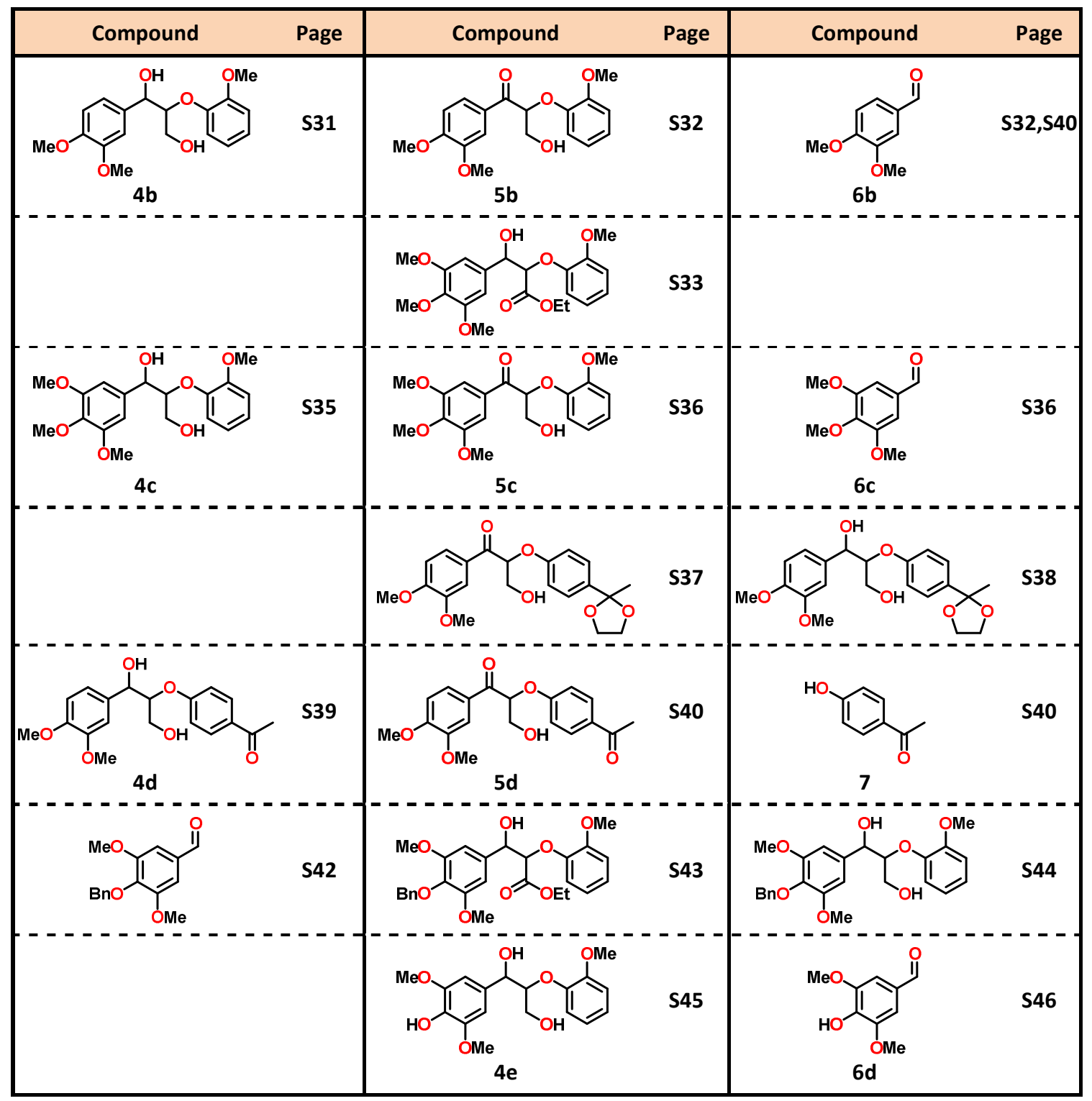




\section{Representative Procedure for Oxidation of Lignin Model Systems}

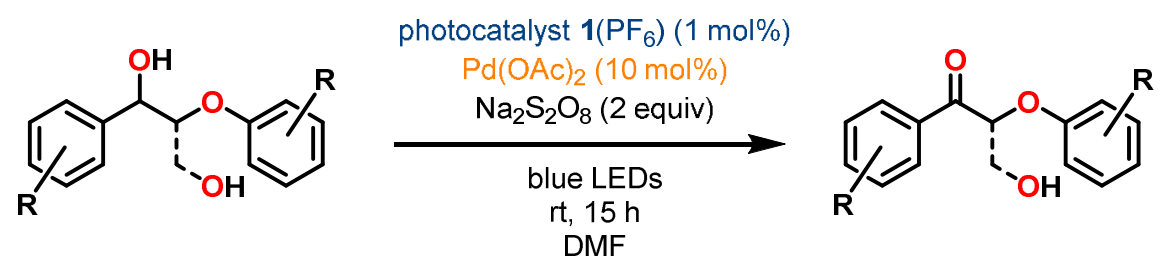

Lignin model substrate $(0.30 \mathrm{mmol})$ was dissolved in DMF $(4.5 \mathrm{~mL})$ in a round bottom flask. This flask was charged with $\left[\operatorname{Ir}\left\{\mathrm{dF}\left(\mathrm{CF}_{3}\right) \text { ppy }\right\}_{2}(\mathrm{dtbbpy})\right] \mathrm{PF}_{6}\left\{\mathbf{1}\left(\mathrm{PF}_{6}\right)\right\}(3.0 \mu \mathrm{mol}, 3.3 \mathrm{mg}, 1 \mathrm{~mol} \%), \mathrm{Pd}(\mathrm{OAc})_{2}(0.030$ mmol, $6.7 \mathrm{mg}, 10 \mathrm{~mol} \%)$, and $\mathrm{Na}_{2} \mathrm{~S}_{2} \mathrm{O}_{8}(0.60 \mathrm{mmol}, 143 \mathrm{mg}, 2$ equiv). The resulting solution was degassed by repeated freeze-pump-thaw cycles ( 3 cycles) and the flask was back-filled with nitrogen. The reaction was then irradiated with a $4.4 \mathrm{~W}$ blue LED strip in a circle around the reaction flask (approximately $5 \mathrm{~cm}$ from the flask) and stirred at room temperature for $15 \mathrm{~h}$. After completion of the reaction, $\mathrm{CH}_{2} \mathrm{Cl}_{2}$ and water were added and the layers were separated. The aqueous layer was extracted with $\mathrm{CH}_{2} \mathrm{Cl}_{2}(3 \mathrm{x})$ and the combined organic layers were washed with $5 \%$ aq. $\mathrm{LiCl}(3 \mathrm{x})$, brine (2x), dried over $\mathrm{Na}_{2} \mathrm{SO}_{4}$ and filtered before concentrating the solution in vacuo. The crude residue can then be purified by column chromatography to afford the desired oxidized product. 


\section{Experimental Section}<smiles>COc1ccc(C(=O)CBr)cc1</smiles>
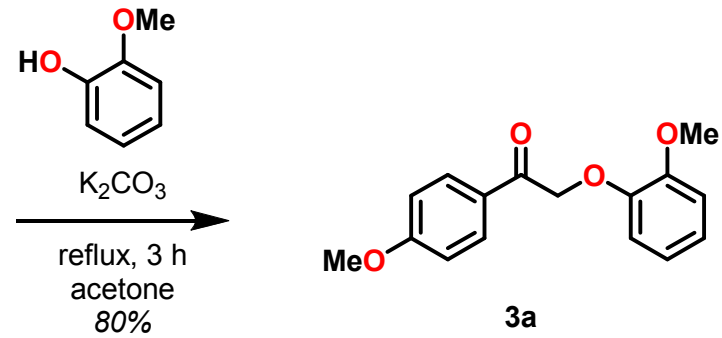

Synthesis of 2-(2-methoxyphenoxy)-1-(4-methoxyphenyl)ethan-1-one (3a). A round bottom flask equipped with a reflux condenser was charged with 2-bromo-1-(4-methoxyphenyl)ethan-1-one (2.50 $\mathrm{g}, 10.9 \mathrm{mmol}), \mathrm{K}_{2} \mathrm{CO}_{3}(2.27 \mathrm{~g}, 16.4 \mathrm{mmol})$, guaiacol $(1.49 \mathrm{~g}, 1.32 \mathrm{~mL}, 12.0 \mathrm{mmol})$, and acetone (75 $\mathrm{mL}$ ). The resulting suspension was stirred at reflux for $3 \mathrm{~h}$, after which it was cooled down to room temperature, filtered and concentrated in vacuo. The resulting solid was purified by recrystallization from EtOH to afford $3 a$ as white needles $(2.37 \mathrm{~g}, 80 \%)$. Spectral data are consistent with those reported in the literature. ${ }^{\mathrm{S} 1}$

${ }^{1} \mathrm{H}$ NMR (400 MHz, CDCl 3 ): $\delta 8.02(\mathrm{~d}, J=9.0 \mathrm{~Hz}, 2 \mathrm{H}), 6.99-6.89(\mathrm{~m}, 2 \mathrm{H}), 6.96(\mathrm{~d}, J=9.0 \mathrm{~Hz}, 2 \mathrm{H}), 6.88-$ $6.82(\mathrm{~m}, 2 \mathrm{H}), 5.28(\mathrm{~s}, 2 \mathrm{H}), 3.89(\mathrm{~s}, 3 \mathrm{H}), 3.88(\mathrm{~s}, 3 \mathrm{H})$.

${ }^{13}$ C NMR (126 MHz, CDCl 3 ): $\delta$ 193.2, 164.0, 149.8, 147.7, 130.6 (2C), 127.8, 122.4, 120.9, 114.8, 114.0 (2C), 112.2, 72.1, 56.0, 55.6.

HRMS (ESI): Calculated for $\mathrm{C}_{16} \mathrm{H}_{17} \mathrm{O}_{4}[\mathrm{M}+\mathrm{H}]^{+}: 273.1121$, found: 273.1120 .

$\mathbf{R}_{\mathbf{f}}$ (hexanes/EtOAc 3:1) $=0.21$. 


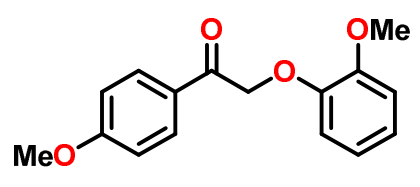

$3 a$

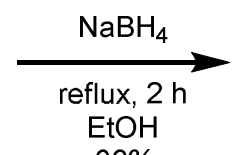

$92 \%$

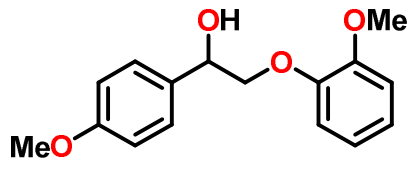

2a

Synthesis of 2-(2-methoxyphenoxy)-1-(4-methoxyphenyl)ethan-1-ol (2a). A round bottom flask was charged with 2-(2-methoxyphenoxy)-1-(4-methoxyphenyl)ethan-1-one (3a, $0.878 \mathrm{~g}, 3.22 \mathrm{mmol}$ ) and EtOH (45 mL). $\mathrm{NaBH}_{4}(0.146 \mathrm{~g}, 3.88 \mathrm{mmol})$ was added in one portion at room temperature. The resulting mixture was refluxed for $2 \mathrm{~h}$, after which it was cooled to room temperature. The solution was diluted with $\mathrm{H}_{2} \mathrm{O}(40 \mathrm{~mL})$ and the $\mathrm{pH}$ was adjusted to $\mathrm{pH}$ 5-6 with $1 \mathrm{M} \mathrm{HCl}$. The resulting solution was stirred at room temperature for $1 \mathrm{~h}$ after which the aqueous phase was extracted with $\mathrm{Et}_{2} \mathrm{O}(3 \mathrm{x}$ $50 \mathrm{~mL}$ ). The combined organic extracts were washed with brine, dried over anhydrous $\mathrm{Na}_{2} \mathrm{SO}_{4}$, filtered and concentrated in vacuo. The residue was purified by column chromatography (hexanes/EtOAc 3:1) to give the title compound as a colorless oil $(0.810 \mathrm{~g}, 92 \%)$. Spectral data are consistent with those reported in the literature. ${ }^{\text {s1 }}$

${ }^{1} \mathrm{H}$ NMR $\left(500 \mathrm{MHz}, \mathrm{CDCl}_{3}\right): \delta 7.36(\mathrm{~d}, J=8.6 \mathrm{~Hz}, 2 \mathrm{H}), 7.02-6.88(\mathrm{~m}, 6 \mathrm{H}), 5.06(\mathrm{dd}, J=9.5,2.9 \mathrm{~Hz}, 1 \mathrm{H})$, $4.15(\mathrm{dd}, J=10.1,2.9 \mathrm{~Hz}, 1 \mathrm{H}), 3.96(\mathrm{t}, J=9.8 \mathrm{~Hz}, 1 \mathrm{H}), 3.89(\mathrm{~s}, 3 \mathrm{H}), 3.81(\mathrm{~s}, 3 \mathrm{H}), 3.38(\mathrm{br} \mathrm{s}, 1 \mathrm{H})$.

${ }^{13} \mathrm{C}$ NMR (126 MHz, CDCl $)$ : $\delta$ 159.6, 150.3, 148.1, 131.7, 127.7 (2C), 122.7, 121.2, 116.1, 114.0 (2C), $112.1,76.5,72.1,56.0,55.5$.

HRMS (ESI): Calculated for $\mathrm{C}_{16} \mathrm{H}_{18} \mathrm{NaO}_{4}[\mathrm{M}+\mathrm{Na}]^{+}:$297.1097, found: 297.1096.

$\mathbf{R}_{\mathrm{f}}($ hexanes $/$ EtOAc 1:1) $=0.41$. 
<smiles>COc1ccc(C(O)COc2ccccc2OC)cc1</smiles>

$2 a$

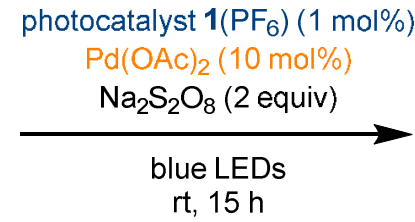

DMF

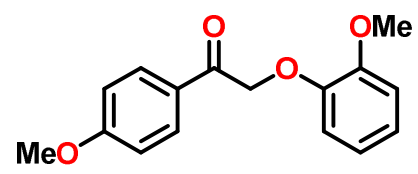

3a, $83 \%$

Oxidation of 2-(2-methoxyphenoxy)-1-(4-methoxyphenyl)ethan-1-ol (2a). Performed according to "Representative Procedure for Oxidation of Lignin Model Systems". A round bottom flask was

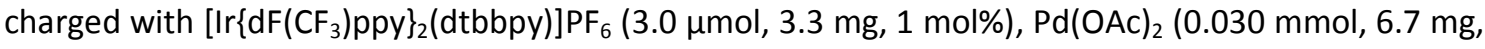
10 mol\%), 2-(2-methoxyphenoxy)-1-(4-methoxyphenyl)ethan-1-ol (2a, $0.30 \mathrm{mmol}, 82 \mathrm{mg}$ ), $\mathrm{Na}_{2} \mathrm{~S}_{2} \mathrm{O}_{8}$ (0.60 mmol, $143 \mathrm{mg}, 2$ equiv) and DMF ( $4.5 \mathrm{~mL})$. The resulting solution was degassed by repeated freeze-pump-thaw cycles ( 3 cycles) and the flask was back-filled with nitrogen. The reaction was then irradiated with a $4.4 \mathrm{~W}$ blue LED strip in a circle around the reaction flask (approximately $5 \mathrm{~cm}$ from the flask) and stirred at room temperature for $15 \mathrm{~h}$. After completion of the reaction, $\mathrm{CH}_{2} \mathrm{Cl}_{2}$ and $\mathrm{H}_{2} \mathrm{O}$ were added and the layers were separated. The aqueous layer was extracted with $\mathrm{CH}_{2} \mathrm{Cl}_{2}(3 \mathrm{x})$ and the combined organic layers were washed with $5 \%$ aq. $\mathrm{LiCl}(3 \mathrm{x})$, brine (2x), dried over $\mathrm{Na}_{2} \mathrm{SO}_{4}$ and filtered before concentrating the solution in vacuo. The crude residue was purified by column chromatography (hexanes/EtOAc 3:1) to afford 2-(2-methoxyphenoxy)-1-(4-methoxyphenyl)ethan-1one (3a) as a white solid (68 mg, 83\%). 
<smiles>COc1ccc(C(C)=O)cc1OC</smiles>
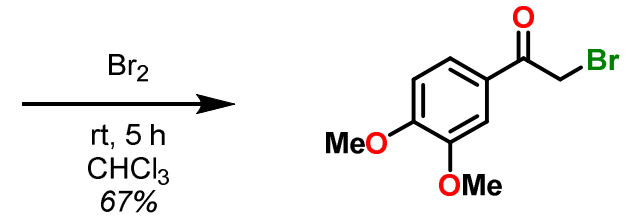

Synthesis of 2-bromo-1-(3,4-dimethoxyphenyl)ethan-1-one. A $\mathrm{CHCl}_{3}$ solution (100 mL) of $\mathrm{Br}_{2}$ (1.19 $\mathrm{mL}, 23.2 \mathrm{mmol})$ was dropwise added to a solution of 1-(3,4-dimethoxyphenyl)ethan-1-one (4.00 g, $22.2 \mathrm{mmol})$ in $\mathrm{CHCl}_{3}(80 \mathrm{~mL})$ at room temperature over $5 \mathrm{~h}$. To the resulting solution was subsequently added a saturated aqueous $\mathrm{Na}_{2} \mathrm{~S}_{2} \mathrm{O}_{3}$ solution. The phases were separated and the organic phase was additionally washed with brine, dried over $\mathrm{Na}_{2} \mathrm{SO}_{4}$, filtered and evaporated under reduced pressure to afford the crude product as a light yellow oil. To the crude residue was added $\mathrm{EtOH}$ and the resulting mixture was cooled to $0{ }^{\circ} \mathrm{C}$ upon which a solid precipitated. The solid was filtered, washed with cold EtOH and dried in vacuo to give the title compound as a white solid (3.85 g, 67\%). Spectral data are consistent with those reported in the literature. ${ }^{.2}$

${ }^{1} \mathrm{H}$ NMR $\left(500 \mathrm{MHz}, \mathrm{CDCl}_{3}\right): \delta 7.62(\mathrm{dd}, J=8.5,2.0 \mathrm{~Hz}, 1 \mathrm{H}), 7.54(\mathrm{~d}, J=2.0 \mathrm{~Hz}, 1 \mathrm{H}), 6.91(\mathrm{~d}, J=8.5 \mathrm{~Hz}$, 1H), $4.41(\mathrm{~s}, 2 \mathrm{H}), 3.97(\mathrm{~s}, 3 \mathrm{H}), 3.95(\mathrm{~s}, 3 \mathrm{H})$.

${ }^{13} \mathrm{C}$ NMR $\left(126 \mathrm{MHz}, \mathrm{CDCl}_{3}\right): \delta 190.2,154.1,149.4,127.2,124.0,111.0,110.2,56.3,56.2,30.5$.

HRMS (ESI): Calculated for $\mathrm{C}_{10} \mathrm{H}_{12} \mathrm{BrO}_{3}[\mathrm{M}+\mathrm{H}]^{+}: 258.9964$, found: 258.9961 .

$\mathbf{R}_{\mathrm{f}}($ hexanes $/$ EtOAc 2:1) $=0.38$. 

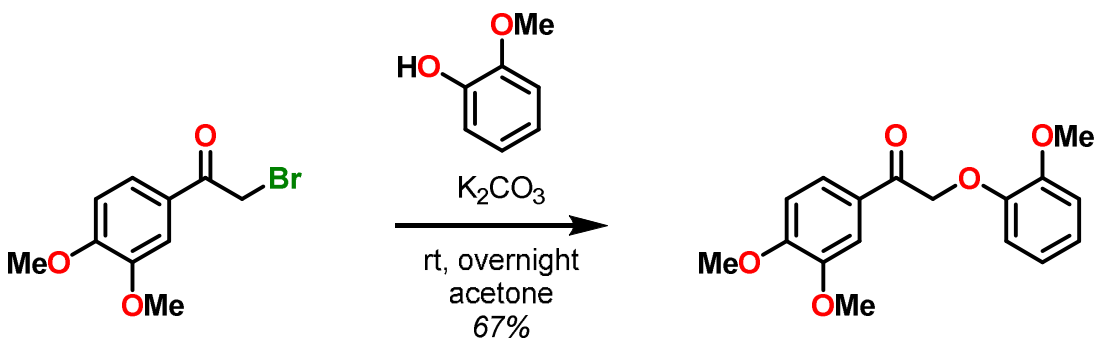

3b

Synthesis of 1-(3,4-dimethoxyphenyl)-2-(2-methoxyphenoxy)ethan-1-one (3b). 2-bromo-1-(3,4dimethoxyphenyl)ethan-1-one $(3.00 \mathrm{~g}, 11.6 \mathrm{mmol})$ was added to a solution of guaiacol $(1.58 \mathrm{~g}, 12.7$ $\mathrm{mmol}$ ) in acetone $(30 \mathrm{~mL})$ containing $\mathrm{K}_{2} \mathrm{CO}_{3}(2.40 \mathrm{~g}, 17.4 \mathrm{mmol})$. The resulting mixture was stirred at room temperature overnight. The solids were filtered off and the resulting solution was evaporated under reduced pressure to give a yellow oily residue, which was left in the fridge overnight. A lightyellow precipitate had formed that was filtered, washed with cold $\mathrm{EtOH}$ and dried in vacuo to give the product as an off-white solid $(1.98 \mathrm{~g}, 67 \%)$. Spectral data are consistent with those reported in the literature. ${ }^{\mathrm{S3}}$

${ }^{1} \mathrm{H}$ NMR (400 MHz, $\left.\mathrm{CDCl}_{3}\right): \delta 7.68(\mathrm{dd}, J=8.5,2.0 \mathrm{~Hz}, 1 \mathrm{H}), 7.60(\mathrm{~d}, J=2.0 \mathrm{~Hz}, 1 \mathrm{H}), 6.99-6.82(\mathrm{~m}, 5 \mathrm{H})$, $5.29(\mathrm{~s}, 2 \mathrm{H}), 3.95(\mathrm{~s}, 3 \mathrm{H}), 3.93(\mathrm{~s}, 3 \mathrm{H}), 3.88(\mathrm{~s}, 3 \mathrm{H})$.

${ }^{13}$ C NMR (126 MHz, $\left.\mathrm{CDCl}_{3}\right): \delta 193.4,153.9,149.8,149.3,147.7,128.0,122.9,122.5,120.9,114.8$, $112.3,110.6,110.3,72.2,56.3,56.2,56.0$.

HRMS (ESI): Calculated for $\mathrm{C}_{17} \mathrm{H}_{19} \mathrm{O}_{5}[\mathrm{M}+\mathrm{H}]^{+}:$303.1227, found: 303.1227.

$\mathbf{R}_{\mathbf{f}}($ hexanes/EtOAc 1:1) $=0.48$. 


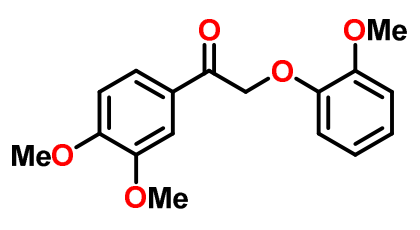

3b

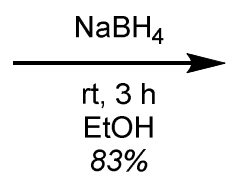

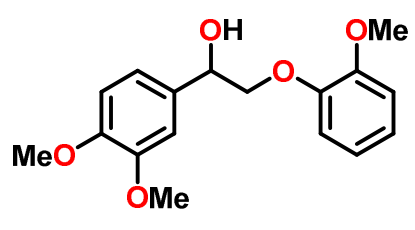

2b

Synthesis of 1-(3,4-dimethoxyphenyl)-2-(2-methoxyphenoxy)ethan-1-ol (2b). $\mathrm{NaBH}_{4}(37.5 \mathrm{mg}, 0.991$ mmol) was added to a suspension of 1-(3,4-dimethoxyphenyl)-2-(2-methoxyphenoxy)ethan-1-one (3b, $0.250 \mathrm{~g}, 0.827 \mathrm{mmol})$ in EtOH $(25 \mathrm{~mL})$. The resulting mixture was stirred at room temperature for $3 \mathrm{~h}$ upon which the reaction mixture gradually became homogeneous. To the solution was added $\mathrm{H}_{2} \mathrm{O}(20 \mathrm{~mL})$ and the $\mathrm{pH}$ was adjusted to $\mathrm{pH} \mathrm{5-6}$ with $1 \mathrm{M} \mathrm{HCl}$. The resulting solution was extracted with $\mathrm{Et}_{2} \mathrm{O}$ and the combined organic extracts were washed with brine, dried over $\mathrm{Na}_{2} \mathrm{SO}_{4}$, filtered and evaporated under reduced pressure to yield the product as a white solid $(0.210 \mathrm{~g}, 83 \%)$. Spectral data are consistent with those reported in the literature..$^{\mathrm{S3}}$

${ }^{1} \mathrm{H}$ NMR $\left(500 \mathrm{MHz}, \mathrm{CDCl}_{3}\right): \delta 7.03-6.98(\mathrm{~m}, 2 \mathrm{H}), 6.97-6.88(\mathrm{~m}, 4 \mathrm{H}), 6.86(\mathrm{~d}, J=8.2 \mathrm{~Hz}, 1 \mathrm{H}), 5.03(\mathrm{dd}, J$ $=9.3,2.8 \mathrm{~Hz}, 1 \mathrm{H}), 4.18(\mathrm{dd}, J=10.1,2.8 \mathrm{~Hz}, 1 \mathrm{H}), 3.99(\mathrm{t}, J=9.7 \mathrm{~Hz}, 1 \mathrm{H}), 3.89(\mathrm{~s}, 3 \mathrm{H}), 3.88(\mathrm{~s}, 3 \mathrm{H}), 3.87$ (s, 3H), $3.36($ br s, 1H).

${ }^{13}$ C NMR (126 MHz, $\left.\mathrm{CDCl}_{3}\right): \delta 150.6,149.6,149.2,148.5,132.7,122.8,121.4,118.9,116.7,112.6$, $111.7,110.1,76.7,72.4,56.2,56.2,56.2$.

HRMS (ESI): Calculated for $\mathrm{C}_{17} \mathrm{H}_{20} \mathrm{NaO}_{5}[\mathrm{M}+\mathrm{Na}]^{+}: 327.1203$, found: 327.1202 .

$\mathbf{R}_{\mathbf{f}}($ hexanes $/$ EtOAc 1:1) $=0.28$. 
<smiles>COc1ccc(C(O)COc2ccccc2OC)cc1OC</smiles>

$2 b$

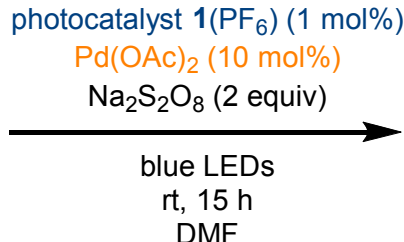

DMF

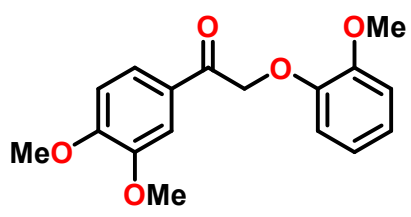

3b, $96 \%$

Oxidation of 1-(3,4-dimethoxyphenyl)-2-(2-methoxyphenoxy)ethan-1-ol (2b). Performed according to "Representative Procedure for Oxidation of Lignin Model Systems". A round bottom flask was charged with $\left[\operatorname{Ir}\left\{\mathrm{dF}\left(\mathrm{CF}_{3}\right) \mathrm{ppy}\right\}_{2}(\mathrm{dtbbpy})\right] \mathrm{PF}_{6}(3.0 \mu \mathrm{mol}, 3.3 \mathrm{mg}, 1 \mathrm{~mol} \%), \mathrm{Pd}(\mathrm{OAc})_{2}(0.030 \mathrm{mmol}, 6.7 \mathrm{mg}$, 10 mol\%), 1-(3,4-dimethoxyphenyl)-2-(2-methoxyphenoxy)ethan-1-ol (2b, $0.30 \mathrm{mmol}, 91 \mathrm{mg}$ ), $\mathrm{Na}_{2} \mathrm{~S}_{2} \mathrm{O}_{8}$ (0.60 mmol, $143 \mathrm{mg}$, 2 equiv) and DMF (4.5 mL). The resulting solution was degassed by repeated freeze-pump-thaw cycles ( 3 cycles) and the flask was back-filled with nitrogen. The reaction was then irradiated with a $4.4 \mathrm{~W}$ blue LED strip in a circle around the reaction flask (approximately 5 $\mathrm{cm}$ from the flask) and stirred at room temperature for $15 \mathrm{~h}$. After completion of the reaction, $\mathrm{CH}_{2} \mathrm{Cl}_{2}$ and $\mathrm{H}_{2} \mathrm{O}$ were added and the layers were separated. The aqueous layer was extracted with $\mathrm{CH}_{2} \mathrm{Cl}_{2}$ (3x) and the combined organic layers were washed with $5 \%$ aq. $\mathrm{LiCl}(3 \mathrm{x})$, brine (2x), dried over $\mathrm{Na}_{2} \mathrm{SO}_{4}$ and filtered before concentrating the solution in vacuo. The crude residue was purified by column chromatography (hexanes/EtOAc 3:1) to afford 1-(3,4-dimethoxyphenyl)-2-(2-methoxyphenoxy)ethan-1-one (3b) as an off-white solid (87 $\mathrm{mg}, 96 \%)$. 

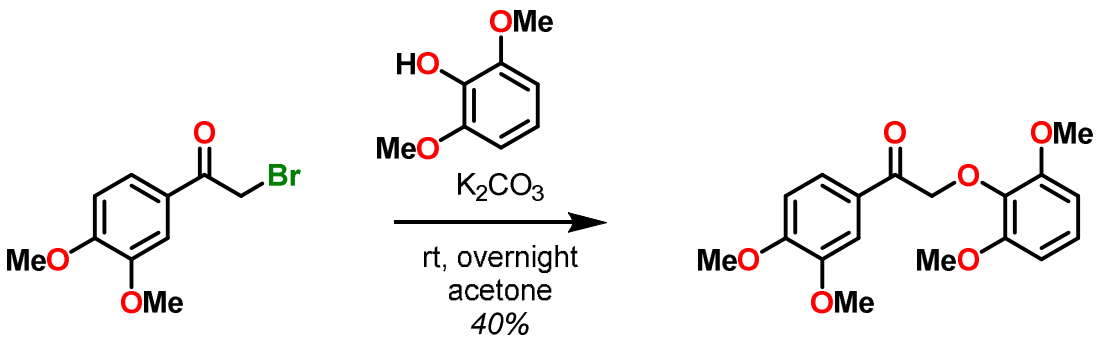

$3 c$

Synthesis of 2-(2,6-dimethoxyphenoxy)-1-(3,4-dimethoxyphenyl)ethan-1-one (3c). 2-Bromo-1-(3,4dimethoxyphenyl)ethan-1-one ( $2.00 \mathrm{~g}, 7.72 \mathrm{mmol})$ was added to a solution of 2,6-dimethoxyphenol $(1.31 \mathrm{~g}, 8.49 \mathrm{mmol})$ in acetone $(30 \mathrm{~mL})$ containing $\mathrm{K}_{2} \mathrm{CO}_{3}(1.60 \mathrm{~g}, 11.6 \mathrm{mmol})$. The resulting mixture was stirred at room temperature overnight. The solids were filtered off and washed with $\mathrm{CH}_{2} \mathrm{Cl}_{2}$, and the resulting solution was evaporated under reduced pressure. The residue was redissolved in $\mathrm{CH}_{2} \mathrm{Cl}_{2}$ and washed with $\mathrm{H}_{2} \mathrm{O}$ and brine. The organic phase was dried over $\mathrm{Na}_{2} \mathrm{SO}_{4}$, filtered and concentrated in vacuo. Purification by column chromatography (hexanes/EtOAc $3: 1$ to $2: 1$ ) afforded the desired product as an off-white solid (1.02 g, 40\%). Spectral data are consistent with those reported in the literature. $^{\mathrm{S4}}$

${ }^{1} \mathrm{H}$ NMR $\left(500 \mathrm{MHz}, \mathrm{CDCl}_{3}\right): \delta 7.76(\mathrm{dd}, J=8.4,1.8 \mathrm{~Hz}, 1 \mathrm{H}), 7.67(\mathrm{~d}, J=1.8 \mathrm{~Hz}, 1 \mathrm{H}), 6.99(\mathrm{t}, J=8.4 \mathrm{~Hz}$, $1 \mathrm{H}), 6.90(\mathrm{~d}, J=8.4 \mathrm{~Hz}, 1 \mathrm{H}), 6.58(\mathrm{~d}, J=8.4 \mathrm{~Hz}, 2 \mathrm{H}), 5.11(\mathrm{~s}, 2 \mathrm{H}), 3.94(\mathrm{~s}, 6 \mathrm{H}), 3.81(\mathrm{~s}, 6 \mathrm{H})$.

${ }^{13}$ C NMR (126 MHz, CDCl $)$ ): $\delta$ 194.0, 153.8, 153.6 (2C), 149.4, 137.4, 128.9, 124.1, 123.4, 111.5, 110.5, $106.0(2 \mathrm{C}), 75.7,56.4(2 \mathrm{C}), 56.3,56.2$.

HRMS (ESI): Calculated for $\mathrm{C}_{18} \mathrm{H}_{21} \mathrm{O}_{6}[\mathrm{M}+\mathrm{H}]^{+}: 333.1333$, found: 333.1332 .

$\mathbf{R}_{\mathbf{f}}($ hexanes $/$ EtOAc 1:1) $=0.40$. 


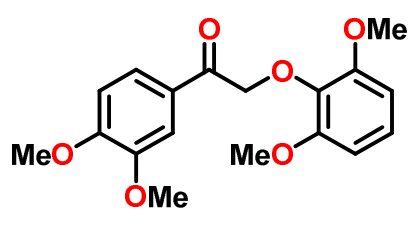

$3 c$

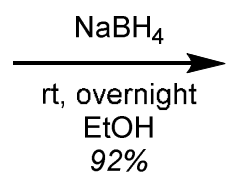

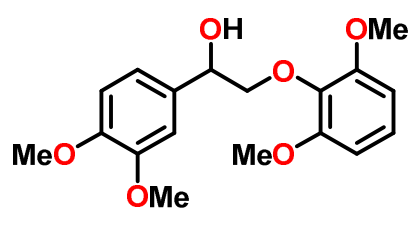

2c

Synthesis of 2-(2,6-dimethoxyphenoxy)-1-(3,4-dimethoxyphenyl)ethan-1-ol (2c). $\mathrm{NaBH}_{4}$ (13.7 mg, $0.361 \mathrm{mmol})$ was added to a suspension of 2-(2,6-dimethoxyphenoxy)-1-(3,4dimethoxyphenyl)ethan-1-one (3c, $0.100 \mathrm{~g}, 0.301 \mathrm{mmol})$ in EtOH $(12 \mathrm{~mL})$. The resulting mixture was stirred at room temperature overnight. To the resulting solution were added $\mathrm{H}_{2} \mathrm{O}$ and $\mathrm{CH}_{2} \mathrm{Cl}_{2}$. The phases were separated and the aqueous phase was additionally extracted with $\mathrm{CH}_{2} \mathrm{Cl}_{2}(3 \mathrm{x})$. The combined organic extracts were washed with brine, dried over $\mathrm{Na}_{2} \mathrm{SO}_{4}$, filtered and evaporated under reduced pressure to give the product as a white solid $(0.092 \mathrm{~g}, 92 \%)$. Spectral data are consistent with those reported in the literature. ${ }^{55}$

${ }^{1} \mathrm{H}$ NMR $\left(500 \mathrm{MHz}, \mathrm{CDCl}_{3}\right): \delta 7.04(\mathrm{t}, J=8.4 \mathrm{~Hz}, 1 \mathrm{H}), 6.97(\mathrm{~d}, J=1.8 \mathrm{~Hz}, 1 \mathrm{H}), 6.90(\mathrm{dd}, J=8.2,1.8 \mathrm{~Hz}$, $1 \mathrm{H}), 6.83(\mathrm{~d}, J=8.2 \mathrm{~Hz}, 1 \mathrm{H}), 6.62(\mathrm{~d}, J=8.4 \mathrm{~Hz}, 2 \mathrm{H}), 4.91(\mathrm{dd}, J=10.0,2.5 \mathrm{~Hz}, 1 \mathrm{H}), 4.52(\mathrm{~s}, 1 \mathrm{H}), 4.40$ (dd, $J=11.0,2.5 \mathrm{~Hz}, 1 \mathrm{H}), 3.88(\mathrm{~s}, 6 \mathrm{H}), 3.88(\mathrm{~s}, 3 \mathrm{H}), 3.86(\mathrm{~s}, 3 \mathrm{H}), 3.70(\mathrm{t}, J=10.5 \mathrm{~Hz}, 1 \mathrm{H})$.

${ }^{13} \mathrm{C}$ NMR (126 MHz, CDCl $)$ : $\delta 153.4$ (2C), 149.1, 148.7, 136.9, 132.1, 124.2, 118.8, 111.1, 109.5, 105.3 (2C), 80.3, 72.3, $56.2(2 \mathrm{C}), 56.1,56.0$.

HRMS (ESI): Calculated for $\mathrm{C}_{18} \mathrm{H}_{22} \mathrm{NaO}_{6}[\mathrm{M}+\mathrm{Na}]^{+}: 357.1309$, found: 357.1307 .

$\mathbf{R}_{\mathrm{f}}($ hexanes/EtOAc 1:1) $=0.38$. 
<smiles>COc1ccc(C(O)COc2c(OC)cccc2OC)cc1OC</smiles>

2c

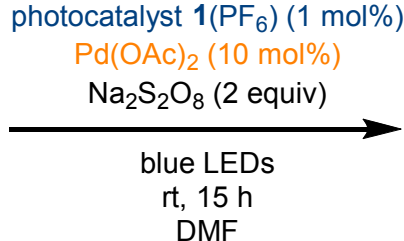

DMF

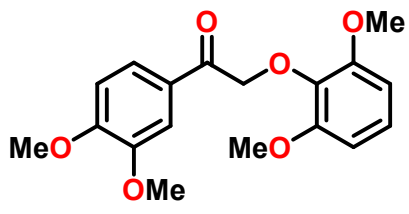

3c, $89 \%$

Oxidation of 2-(2,6-dimethoxyphenoxy)-1-(3,4-dimethoxyphenyl)ethan-1-ol (2c). Performed according to "Representative Procedure for Oxidation of Lignin Model Systems". A round bottom flask was charged with $\left[\operatorname{Ir}\left\{\mathrm{dF}\left(\mathrm{CF}_{3}\right) \mathrm{ppy}_{2}(\mathrm{dtbbpy})\right] \mathrm{PF}_{6}(3.0 \mu \mathrm{mol}, 3.3 \mathrm{mg}, 1 \mathrm{~mol} \%), \mathrm{Pd}(\mathrm{OAc})_{2}(0.030\right.$ mmol, $6.7 \mathrm{mg}, 10 \mathrm{~mol} \%), 2$-(2,6-dimethoxyphenoxy)-1-(3,4-dimethoxyphenyl)ethan-1-ol (2c, 0.30 mmol, $100 \mathrm{mg}), \mathrm{Na}_{2} \mathrm{~S}_{2} \mathrm{O}_{8}(0.60 \mathrm{mmol}, 143 \mathrm{mg}, 2$ equiv) and $\mathrm{DMF}(4.5 \mathrm{~mL})$. The resulting solution was degassed by repeated freeze-pump-thaw cycles ( 3 cycles) and the flask was back-filled with nitrogen. The reaction was then irradiated with a $4.4 \mathrm{~W}$ blue LED strip in a circle around the reaction flask (approximately $5 \mathrm{~cm}$ from the flask) and stirred at room temperature for $15 \mathrm{~h}$. After completion of the reaction, $\mathrm{CH}_{2} \mathrm{Cl}_{2}$ and $\mathrm{H}_{2} \mathrm{O}$ were added and the layers were separated. The aqueous layer was extracted with $\mathrm{CH}_{2} \mathrm{Cl}_{2}(3 \mathrm{x})$ and the combined organic layers were washed with $5 \%$ aq. $\mathrm{LiCl}(3 \mathrm{x})$, brine (2x), dried over $\mathrm{Na}_{2} \mathrm{SO}_{4}$ and filtered before concentrating the solution in vacuo. The crude residue was purified by column chromatography (hexanes/EtOAc 3:1) to afford 2-(2,6-dimethoxyphenoxy)-1(3,4-dimethoxyphenyl)ethan-1-one (3c) as a white solid (89 mg, 89\%). 

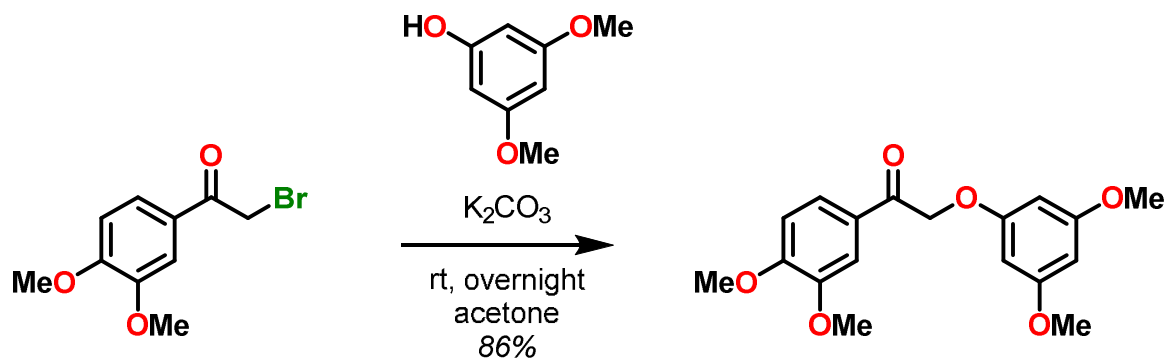

3d

Synthesis of 2-(3,5-dimethoxyphenoxy)-1-(3,4-dimethoxyphenyl)ethan-1-one (3d). 2-Bromo-1-(3,4dimethoxyphenyl)ethan-1-one $(2.00 \mathrm{~g}, 7.72 \mathrm{mmol})$ was added to a solution of 3,5-dimethoxyphenol $(1.31 \mathrm{~g}, 8.49 \mathrm{mmol})$ in acetone $(30 \mathrm{~mL})$ containing $\mathrm{K}_{2} \mathrm{CO}_{3}(1.60 \mathrm{~g}, 11.6 \mathrm{mmol})$. The resulting mixture was stirred at room temperature overnight. The solids were filtered off and washed with $\mathrm{CH}_{2} \mathrm{Cl}_{2}$, and the resulting solution was evaporated under reduced pressure. The residue was redissolved in $\mathrm{CH}_{2} \mathrm{Cl}_{2}$ and washed with $\mathrm{H}_{2} \mathrm{O}$ and brine. The organic phase was dried over $\mathrm{Na}_{2} \mathrm{SO}_{4}$, filtered and concentrated in vacuo. Purification by column chromatography (hexanes/EtOAc $3: 1$ to $2: 1$ ) afforded the desired product as an off-white solid $(2.20 \mathrm{~g}, 86 \%)$. Spectral data are consistent with those reported in the literature. $^{\mathrm{s2}}$

${ }^{1}{ }^{H}$ NMR $\left(500 \mathrm{MHz}, \mathrm{CDCl}_{3}\right): \delta 7.62(\mathrm{dd}, J=8.4,1.8 \mathrm{~Hz}, 1 \mathrm{H}), 7.55(\mathrm{~d}, J=1.8 \mathrm{~Hz}, 1 \mathrm{H}), 6.90(\mathrm{~d}, J=8.4 \mathrm{~Hz}$, $1 \mathrm{H}), 6.13(\mathrm{~d}, J=2.0 \mathrm{~Hz}, 2 \mathrm{H}), 6.10(\mathrm{t}, J=2.0 \mathrm{~Hz}, 1 \mathrm{H}), 5.18(\mathrm{~s}, 2 \mathrm{H}), 3.95(\mathrm{~s}, 3 \mathrm{H}), 3.93(\mathrm{~s}, 3 \mathrm{H}), 3.75(\mathrm{~s}, 6 \mathrm{H})$.

${ }^{13} \mathrm{C}$ NMR (126 MHz, CDCl $): \delta$ 193.0, 161.9 (2C), 160.3, 154.3, 149.7, 128.2, 123.1, 111.1, 110.6, 94.2 $(2 \mathrm{C}+1 \mathrm{C}), 71.1,56.3(2 \mathrm{C}), 55.5(2 \mathrm{C})$.

HRMS (ESI): Calculated for $\mathrm{C}_{18} \mathrm{H}_{21} \mathrm{O}_{6}[\mathrm{M}+\mathrm{H}]^{+}: 333.1333$, found: 333.1333 .

$\mathbf{R}_{\mathrm{f}}($ hexanes $/$ EtOAc 1:1) $=0.50$. 
<smiles>COc1cc(OC)cc(OCC(=O)c2ccc(OC)c(OC)c2)c1</smiles>

3d

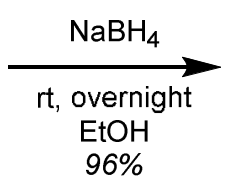

$96 \%$

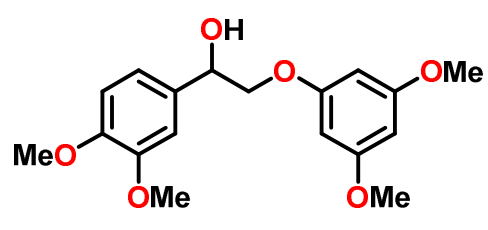

2d

Synthesis of 2-(3,5-dimethoxyphenoxy)-1-(3,4-dimethoxyphenyl)ethan-1-ol (2d). $\mathrm{NaBH}_{4}$ (34.2 mg, $0.903 \mathrm{mmol})$ was added to a suspension of 2-(3,5-dimethoxyphenoxy)-1-(3,4dimethoxyphenyl)ethan-1-one (3d, $0.250 \mathrm{~g}, 0.752 \mathrm{mmol})$ in EtOH $(20 \mathrm{~mL})$. The resulting mixture was stirred at room temperature overnight. $\mathrm{H}_{2} \mathrm{O}$ and $\mathrm{CH}_{2} \mathrm{Cl}_{2}$ were added to the resulting solution. The phases were separated and the aqueous phase was additionally extracted with $\mathrm{CH}_{2} \mathrm{Cl}_{2}(3 \mathrm{x})$. The combined organic extracts were washed with brine, dried over $\mathrm{Na}_{2} \mathrm{SO}_{4}$, filtered and evaporated under reduced pressure to give the product as a white solid $(0.240 \mathrm{~g}, 96 \%)$.

${ }^{1} \mathrm{H}$ NMR $\left(500 \mathrm{MHz}, \mathrm{CDCl}_{3}\right): \delta 7.01(\mathrm{~d}, J=1.9 \mathrm{~Hz}, 1 \mathrm{H}), 6.96(\mathrm{dd}, J=8.2,1.9 \mathrm{~Hz}, 1 \mathrm{H}), 6.88(\mathrm{~d}, J=8.2 \mathrm{~Hz}$, $1 \mathrm{H}), 6.12-6.09(\mathrm{~m}, 3 \mathrm{H}), 5.06(\mathrm{dd}, J=8.8,3.1 \mathrm{~Hz}, 1 \mathrm{H}), 4.04(\mathrm{dd}, J=9.6,3.1 \mathrm{~Hz}, 1 \mathrm{H}), 3.97(\mathrm{t}, J=9.2 \mathrm{~Hz}$, 1H), $3.91(\mathrm{~s}, 3 \mathrm{H}), 3.89(\mathrm{~s}, 3 \mathrm{H}), 3.76(\mathrm{~s}, 6 \mathrm{H}), 2.74(\mathrm{br} \mathrm{s}, 1 \mathrm{H})$.

${ }^{13}$ C NMR (126 MHz, CDCl $): \delta 161.7$ (2C), 160.4, 149.3, 149.1, 132.3, 118.8, 111.2, 109.5, 93.7 (1C + 2C), 73.6, 72.5, 56.1, 56.0, 55.5 (2C).

HRMS (ESI): Calculated for $\mathrm{C}_{18} \mathrm{H}_{22} \mathrm{NaO}_{6}[\mathrm{M}+\mathrm{Na}]^{+}: 357.1309$, found: 357.1309 .

$\mathbf{R}_{\mathrm{f}}($ hexanes/EtOAc 1:1) $=0.44$. 


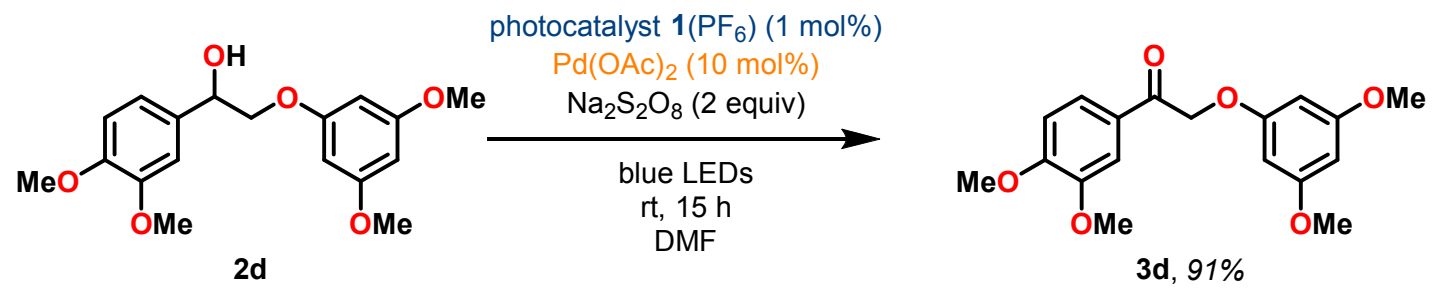

Oxidation of 2-(3,5-dimethoxyphenoxy)-1-(3,4-dimethoxyphenyl)ethan-1-ol (2d). Performed according to "Representative Procedure for Oxidation of Lignin Model Systems". A round bottom flask was charged with $\left[\operatorname{Ir}\left\{\mathrm{dF}\left(\mathrm{CF}_{3}\right) \mathrm{ppy}_{2}(\mathrm{dtbbpy})\right] \mathrm{PF}_{6}(3.0 \mu \mathrm{mol}, 3.3 \mathrm{mg}, 1 \mathrm{~mol} \%), \mathrm{Pd}(\mathrm{OAc})_{2}(0.030\right.$ mmol, $6.7 \mathrm{mg}, 10 \mathrm{~mol} \%), 2$-(3,5-dimethoxyphenoxy)-1-(3,4-dimethoxyphenyl)ethan-1-ol (2d, 0.30 mmol, $100 \mathrm{mg}), \mathrm{Na}_{2} \mathrm{~S}_{2} \mathrm{O}_{8}(0.60 \mathrm{mmol}, 143 \mathrm{mg}, 2$ equiv) and $\mathrm{DMF}(4.5 \mathrm{~mL})$. The resulting solution was degassed by repeated freeze-pump-thaw cycles ( 3 cycles) and the flask was back-filled with nitrogen. The reaction was then irradiated with a $4.4 \mathrm{~W}$ blue LED strip in a circle around the reaction flask (approximately $5 \mathrm{~cm}$ from the flask) and stirred at room temperature for $15 \mathrm{~h}$. After completion of the reaction, $\mathrm{CH}_{2} \mathrm{Cl}_{2}$ and $\mathrm{H}_{2} \mathrm{O}$ were added and the layers were separated. The aqueous layer was extracted with $\mathrm{CH}_{2} \mathrm{Cl}_{2}(3 \mathrm{x})$ and the combined organic layers were washed with $5 \%$ aq. $\mathrm{LiCl}(3 \mathrm{x})$, brine (2x), dried over $\mathrm{Na}_{2} \mathrm{SO}_{4}$ and filtered before concentrating the solution in vacuo. The crude residue was purified by column chromatography (hexanes/EtOAc 4:1) to afford 2-(3,5-dimethoxyphenoxy)-1(3,4-dimethoxyphenyl)ethan-1-one (3d) as a white solid (91 mg, 91\%). 

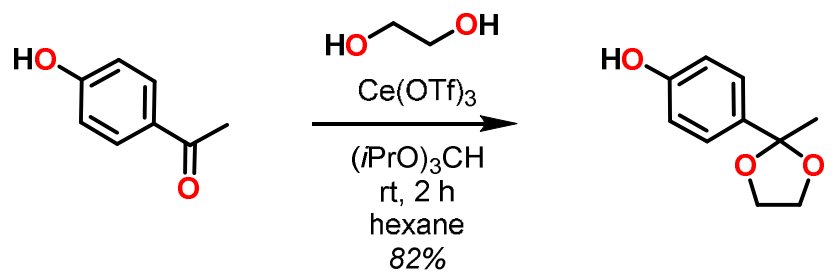

Synthesis of 4-(2-methyl-1,3-dioxolan-2-yl)phenol. This substrate was prepared following a previously described protocol. ${ }^{\mathrm{S} 6}$ To a mixture of 4-hydroxyacetophenone $(1.36 \mathrm{~g}, 10.0 \mathrm{mmol})$, ethane-1,2-diol $(0.850 \mathrm{~mL}, 15.0 \mathrm{mmol})$, and Ce(OTf $)_{3}(58.0 \mathrm{mg}, 0.10 \mathrm{mmol})$ in dry hexane $(20 \mathrm{~mL}) \mathrm{was}$ added $\mathrm{HC}(\mathrm{PrO})_{3}(3.34 \mathrm{~mL}, 15.0 \mathrm{mmol})$ at $25-30{ }^{\circ} \mathrm{C}$. The mixture was stirred for $2 \mathrm{~h}$ and quenched with $\mathrm{Et}_{3} \mathrm{~N}(0.505 \mathrm{~mL}, 5.0 \mathrm{mmol})$ and sat. $\mathrm{NaHCO}_{3}$. The organic materials were extracted with $\mathrm{Et}_{2} \mathrm{O}$ containing $0.1 \% \mathrm{Et}_{3} \mathrm{~N}$, washed with brine, dried over $\mathrm{Na}_{2} \mathrm{SO}_{4}$, filtered and evaporated. The residue was purified by column chromatography (hexanes/EtOAc/Et ${ }_{3} \mathrm{~N}$ 93:7:0.1) to afford the desired product as a white solid (1.48 g, 82\%).

${ }^{1}$ H NMR (500 MHz, acetone- $\left.d_{6}\right): \delta 8.27(s, 1 H), 7.27(\mathrm{~d}, J=8.5 \mathrm{~Hz}, 2 \mathrm{H}), 6.79(\mathrm{~d}, J=8.5 \mathrm{~Hz}, 2 \mathrm{H}), 4.00-$ $3.92(\mathrm{~m}, 2 \mathrm{H}), 3.75-3.67(\mathrm{~m}, 2 \mathrm{H}), 1.53(\mathrm{~s}, 3 \mathrm{H})$.

${ }^{13} \mathrm{C}$ NMR (126 MHz, acetone- $\left.d_{6}\right): \delta 157.8,135.6,127.4(2 \mathrm{C}), 115.6(2 \mathrm{C}), 109.3,65.0(2 \mathrm{C}), 28.0$.

HRMS (ESI): Calculated for $\mathrm{C}_{10} \mathrm{H}_{13} \mathrm{O}_{3}[\mathrm{M}+\mathrm{H}]^{+}: 181.0859$, found: 181.0857.

$\mathbf{R}_{\mathbf{f}}$ (hexanes/EtOAc 1:1) $=0.65$.
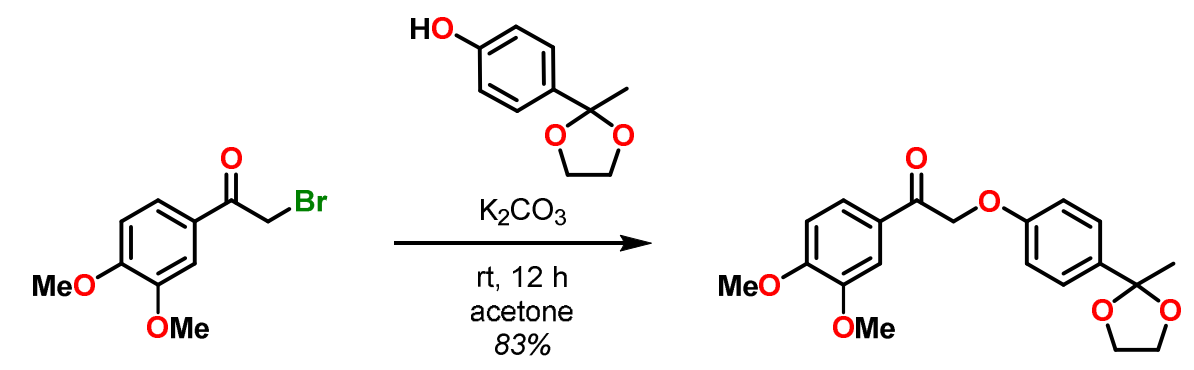

Synthesis of 1-(3,4-dimethoxyphenyl)-2-(4-(2-methyl-1,3-dioxolan-2-yl)phenoxy)ethan-1-one. 2Bromo-1-(3,4-dimethoxyphenyl)ethan-1-one (1.89 g, $7.33 \mathrm{mmol})$ was added to a solution of 4-(2- 
methyl-1,3-dioxolan-2-yl)phenol $(1.45 \mathrm{~g}, 8.10 \mathrm{mmol})$ in acetone $(20 \mathrm{~mL})$ containing $\mathrm{K}_{2} \mathrm{CO}_{3}(1.52 \mathrm{~g}$, $11.0 \mathrm{mmol})$. The resulting mixture was stirred at room temperature overnight. The solids were filtered off and the resulting solution was evaporated under reduced pressure to give a yellow oily residue, which was purified by column chromatography (hexanes/EtOAc/Et ${ }_{3} \mathrm{~N} 70: 30: 0.1$ ) to give the product as an off-white solid (2.15 g, 83\%).

${ }^{1} \mathrm{H}$ NMR $\left(500 \mathrm{MHz}, \mathrm{CDCl}_{3}\right): \delta 7.65(\mathrm{dd}, J=8.4,1.7 \mathrm{~Hz}, 1 \mathrm{H}), 7.56(\mathrm{~d}, J=1.7 \mathrm{~Hz}, 1 \mathrm{H}), 7.38(\mathrm{~d}, J=8.6 \mathrm{~Hz}$, $2 \mathrm{H}), 6.92-6.86(\mathrm{~m}, 3 \mathrm{H}), 5.22(\mathrm{~s}, 2 \mathrm{H}), 4.03-3.98(\mathrm{~m}, 2 \mathrm{H}), 3.95(\mathrm{~s}, 3 \mathrm{H}), 3.93(\mathrm{~s}, 3 \mathrm{H}), 3.78-3.73(\mathrm{~m}, 2 \mathrm{H})$, $1.62(\mathrm{~s}, 3 \mathrm{H})$.

${ }^{13} \mathrm{C}$ NMR (126 MHz, CDCl 3 ): $\delta$ 193.2, 157.9, 154.1, 149.4, 136.6, 127.9, 126.8 (2C), 123.0, 114.5 (2C), $110.5,110.3,108.8,70.8,64.5(2 C), 56.3,56.2,27.8$.

HRMS (ESI): Calculated for $\mathrm{C}_{20} \mathrm{H}_{22} \mathrm{NaO}_{6}[\mathrm{M}+\mathrm{Na}]^{+}: 381.1309$, found: 381.1311.

$\mathbf{R}_{\mathbf{f}}($ hexanes/EtOAc 1:1) $=0.46$.
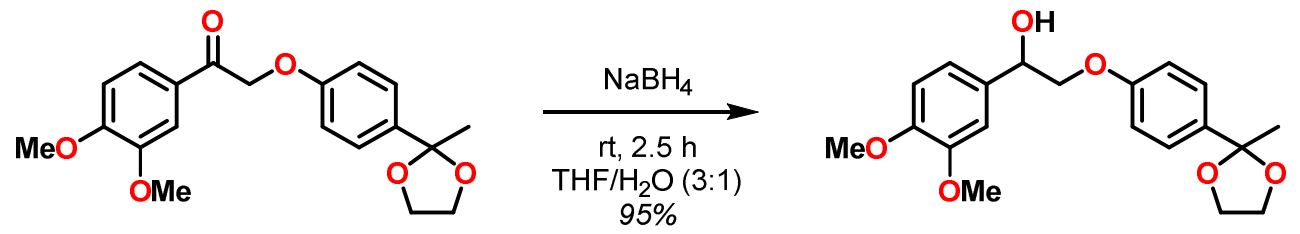

Synthesis of 1-(3,4-dimethoxyphenyl)-2-(4-(2-methyl-1,3-dioxolan-2-yl)phenoxy)ethan-1-ol. To a solution of 1-(3,4-dimethoxyphenyl)-2-(4-(2-methyl-1,3-dioxolan-2-yl)phenoxy)ethan-1-one (820 mg, $2.28 \mathrm{mmol})$ in $\mathrm{THF} / \mathrm{H}_{2} \mathrm{O}(3: 1,2.0 \mathrm{~mL})$ was added $\mathrm{NaBH}_{4}$ in three portions (434 mg, $\left.11.4 \mathrm{mmol}\right)$. The reaction was stirred at room temperature for $2.5 \mathrm{~h}$ and then diluted with $\mathrm{H}_{2} \mathrm{O}$ and $\mathrm{CH}_{2} \mathrm{Cl}_{2}$. The phases were separated and the aqueous phase was extracted with $\mathrm{CH}_{2} \mathrm{Cl}_{2}(3 \mathrm{x})$. The organic phases were collected, dried over $\mathrm{Na}_{2} \mathrm{SO}_{4}$, filtered and concentrated under reduced pressure. The crude reaction mixture was purified by column chromatography (hexanes/EtOAc/Et ${ }_{3} \mathrm{~N} 70: 30: 0.1$ ) to give the desired product as a viscous colorless oil ( $808 \mathrm{mg}, 95 \%)$. 
${ }^{1} \mathrm{H}$ NMR $\left(400 \mathrm{MHz}\right.$, acetone- $\left.d_{6}\right): \delta 7.35(\mathrm{~d}, J=8.7 \mathrm{~Hz}, 2 \mathrm{H}), 7.13(\mathrm{~d}, J=1.8 \mathrm{~Hz}, 1 \mathrm{H}), 7.01(\mathrm{dd}, J=8.2,1.8$ $\mathrm{Hz}, 1 \mathrm{H}), 6.92(\mathrm{~d}, J=8.2 \mathrm{~Hz}, 1 \mathrm{H}), 6.90(\mathrm{~d}, J=8.7 \mathrm{~Hz}, 2 \mathrm{H}), 5.00(\mathrm{dt}, J=7.7,4.0 \mathrm{~Hz}, 1 \mathrm{H}), 4.59(\mathrm{~d}, J=3.8 \mathrm{~Hz}$, $1 \mathrm{H}), 4.07(\mathrm{dd}, J=9.7,4.2 \mathrm{~Hz}, 1 \mathrm{H}), 4.03(\mathrm{dd}, J=9.7,7.7 \mathrm{~Hz}, 1 \mathrm{H}), 3.99-3.94(\mathrm{~m}, 2 \mathrm{H}), 3.82(\mathrm{~s}, 3 \mathrm{H}), 3.80(\mathrm{~s}$, $3 \mathrm{H}), 3.73-3.68(\mathrm{~m}, 2 \mathrm{H}), 1.53(\mathrm{~s}, 3 \mathrm{H})$.

${ }^{13}$ C NMR (126 MHz, acetone- $\left.d_{6}\right): \delta$ 159.5, 150.2, 149.8, 136.9, 135.5, 127.3 (2C), 119.4, 114.9 (2C), $112.5,111.3,109.2,74.5,72.5,65.0(2 \mathrm{C}), 56.1,56.0,28.0$.

HRMS (ESI): Calculated for $\mathrm{C}_{20} \mathrm{H}_{25} \mathrm{O}_{6}[\mathrm{M}+\mathrm{H}]^{+}: 361.1646$, found: 361.1648 .

$\mathbf{R}_{\mathbf{f}}($ hexanes/EtOAc 1:1) $=0.35$.
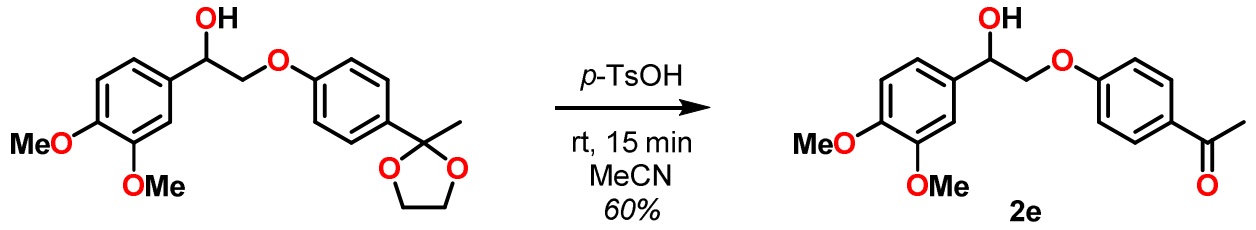

Synthesis of 1-(4-(2-(3,4-dimethoxyphenyl)-2-hydroxyethoxy)phenyl)ethan-1-one (2e). $p$ - $\mathrm{TsOH} \cdot \mathrm{H}_{2} \mathrm{O}$ (390 mg, $2.05 \mathrm{mmol})$ was added to a solution of 1-(3,4-dimethoxyphenyl)-2-(4-(2-methyl-1,3dioxolan-2-yl)phenoxy)ethan-1-ol (740 mg, $2.05 \mathrm{mmol})$ in MeCN (20 mL). The resulting solution was stirred for $15 \mathrm{~min}$ at room temperature and then concentrated under reduced pressure. The crude residue was purified by column chromatography (hexanes/EtOAc $7: 3$ ) to give the title product as a white semisolid (410 mg, 60\%).

${ }^{1} \mathrm{H}$ NMR $\left(500 \mathrm{MHz}, \mathrm{CDCl}_{3}\right): \delta 7.94(\mathrm{~d}, J=8.8 \mathrm{~Hz}, 2 \mathrm{H}), 7.02(\mathrm{~d}, J=1.7 \mathrm{~Hz}, 1 \mathrm{H}), 6.98(\mathrm{dd}, J=8.3,1.7 \mathrm{~Hz}$, $1 \mathrm{H}), 6.96(\mathrm{~d}, J=8.8 \mathrm{~Hz}, 2 \mathrm{H}), 6.89(\mathrm{~d}, J=8.3 \mathrm{~Hz}, 1 \mathrm{H}), 5.11(\mathrm{dd}, J=8.5,3.3 \mathrm{~Hz}, 1 \mathrm{H}), 4.14(\mathrm{dd}, J=9.5,3.3$ $\mathrm{Hz}, 1 \mathrm{H}), 4.11-4.06(\mathrm{~m}, 1 \mathrm{H}), 3.92(\mathrm{~s}, 3 \mathrm{H}), 3.90(\mathrm{~s}, 3 \mathrm{H}), 2.65(\mathrm{br} \mathrm{s}, 1 \mathrm{H}), 2.56(\mathrm{~s}, 3 \mathrm{H})$.

${ }^{13} \mathrm{C}$ NMR (101 MHz, CDCl $)$ ): $\delta$ 196.9, 162.4, 149.2, 149.0, 132.2, 130.8, 130.7 (2C), 118.7, 114.3 (2C), $111.2,109.4,73.5,72.3,56.0(2 C), 26.4$. 
HRMS (ESI): Calculated for $\mathrm{C}_{18} \mathrm{H}_{20} \mathrm{NaO}_{5}[\mathrm{M}+\mathrm{Na}]^{+}: 339.1203$, found: 339.1202.

$\mathbf{R}_{\mathbf{f}}$ (hexanes/EtOAc 1:1) $=0.24$.

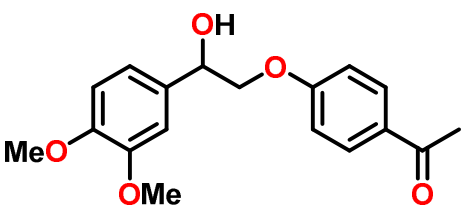

$2 e$

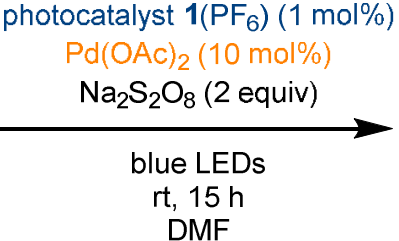

DMF

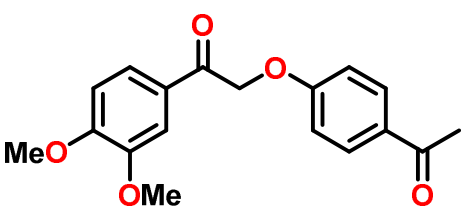

3e, $87 \%$

Oxidation of 1-(4-(2-(3,4-dimethoxyphenyl)-2-hydroxyethoxy)phenyl)ethan-1-one (2e). Performed according to "Representative Procedure for Oxidation of Lignin Model Systems". A round bottom flask was charged with $\left[\operatorname{Ir}\left\{\mathrm{dF}\left(\mathrm{CF}_{3}\right) \mathrm{ppy}\right\}_{2}(\mathrm{dtbbpy})\right] \mathrm{PF}_{6}(3.0 \mu \mathrm{mol}, 3.3 \mathrm{mg}, 1 \mathrm{~mol} \%), \mathrm{Pd}(\mathrm{OAc})_{2}(0.030$ mmol, 6.7 mg, 10 mol\%), 1-(4-(2-(3,4-dimethoxyphenyl)-2-hydroxyethoxy)phenyl)ethan-1-one (2e, $0.30 \mathrm{mmol}, 95 \mathrm{mg}), \mathrm{Na}_{2} \mathrm{~S}_{2} \mathrm{O}_{8}(0.60 \mathrm{mmol}, 143 \mathrm{mg}, 2$ equiv) and DMF $(4.5 \mathrm{~mL})$. The resulting solution was degassed by repeated freeze-pump-thaw cycles (3 cycles) and the flask was back-filled with nitrogen. The reaction was then irradiated with a $4.4 \mathrm{~W}$ blue LED strip in a circle around the reaction flask (approximately $5 \mathrm{~cm}$ from the flask) and stirred at room temperature for $15 \mathrm{~h}$. After completion of the reaction, $\mathrm{CH}_{2} \mathrm{Cl}_{2}$ and $\mathrm{H}_{2} \mathrm{O}$ were added and the layers were separated. The aqueous layer was extracted with $\mathrm{CH}_{2} \mathrm{Cl}_{2}(3 x)$ and the combined organic layers were washed with $5 \%$ aq. $\mathrm{LiCl}(3 \mathrm{x})$, brine (2x), dried over $\mathrm{Na}_{2} \mathrm{SO}_{4}$ and filtered before concentrating the solution in vacuo. The crude residue was purified by column chromatography (hexanes/EtOAc 4:1) to afford 2-(4-acetylphenoxy)-1-(3,4dimethoxyphenyl)ethan-1-one (3e) as a white solid (82 $\mathrm{mg}, 87 \%$ ).

\section{2-(4-acetylphenoxy)-1-(3,4-dimethoxyphenyl)ethan-1-one (3e)}

${ }^{1}$ H NMR (500 MHz, $\left.\mathrm{CDCl}_{3}\right): \delta 7.93(\mathrm{~d}, J=8.8 \mathrm{~Hz}, 2 \mathrm{H}), 7.64(\mathrm{dd}, J=8.4,1.7 \mathrm{~Hz}, 1 \mathrm{H}), 7.55(\mathrm{~d}, J=1.7 \mathrm{~Hz}$, 1H), $6.97(\mathrm{~d}, J=8.8 \mathrm{~Hz}, 2 \mathrm{H}), 6.92(\mathrm{~d}, J=8.4 \mathrm{~Hz}, 1 \mathrm{H}), 5.32(\mathrm{~s}, 2 \mathrm{H}), 3.97(\mathrm{~s}, 3 \mathrm{H}), 3.94(\mathrm{~s}, 3 \mathrm{H}), 2.55(\mathrm{~s}, 3 \mathrm{H})$.

${ }^{13} \mathrm{C}$ NMR (126 MHz, $\left.\mathrm{CDCl}_{3}\right): \delta 196.8,192.3,162.0,154.3,149.6,131.2,130.8(2 \mathrm{C}), 127.6,122.9,114.6$ (2C), $110.4,110.3,70.5,56.3,56.2,26.5$. 
HRMS (ESI): Calculated for $\mathrm{C}_{18} \mathrm{H}_{18} \mathrm{NaO}_{5}[\mathrm{M}+\mathrm{Na}]^{+}: 337.1046$, found: 337.1044 .

$\mathbf{R}_{\mathbf{f}}($ hexanes/EtOAc 1:2) $=0.47$.
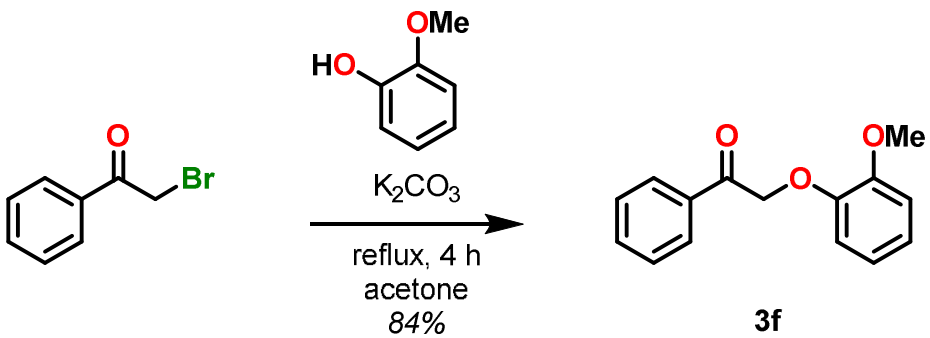

Synthesis of 2-(2-methoxyphenoxy)-1-phenylethan-1-one (3f). 2-Bromo-1-phenylethan-1-one (1.99 $\mathrm{g}, 10.0 \mathrm{mmol})$ was added to a solution of guaiacol $(1.37 \mathrm{~g}, 11.0 \mathrm{mmol})$ in acetone $(30 \mathrm{~mL})$ containing $\mathrm{K}_{2} \mathrm{CO}_{3}(2.07 \mathrm{~g}, 15.0 \mathrm{mmol})$. The resulting mixture was refluxed for $4 \mathrm{~h}$ after which it was cooled down to room temperature. The solids were then filtered off, washed with acetone, and the solvent was removed under reduced pressure. Recrystallization from hot EtOH gave the title compound as white needles (2.03 g, 84\%). Spectral data are consistent with those reported in the literature. ${ }^{\mathrm{S3}}$

${ }^{1}$ H NMR (400 MHz, $\left.\mathrm{CDCl}_{3}\right): \delta 8.01(\mathrm{~d}, J=7.6 \mathrm{~Hz}, 2 \mathrm{H}), 7.60(\mathrm{t}, J=7.6 \mathrm{~Hz}, 1 \mathrm{H}), 7.49(\mathrm{t}, J=7.6 \mathrm{~Hz}, 2 \mathrm{H})$, 7.00-6.90 (m, 2H), 6.87-6.83 (m, 2H), $5.35(\mathrm{~s}, 2 \mathrm{H}), 3.88(\mathrm{~s}, 3 \mathrm{H})$.

${ }^{13} \mathrm{C}$ NMR (126 MHz, CDCl $): \delta 194.7,149.9,147.6,134.7,133.9,128.9(2 \mathrm{C}), 128.2(2 \mathrm{C}), 122.6,120.9$, $115.0,112.3,72.2,56.0$.

HRMS (ESI): Calculated for $\mathrm{C}_{15} \mathrm{H}_{15} \mathrm{O}_{3}[\mathrm{M}+\mathrm{H}]^{+}:$:243.1016, found: 243.1015 .

$\mathbf{R}_{\mathbf{f}}($ hexanes/EtOAc 2:1) $=0.53$. 


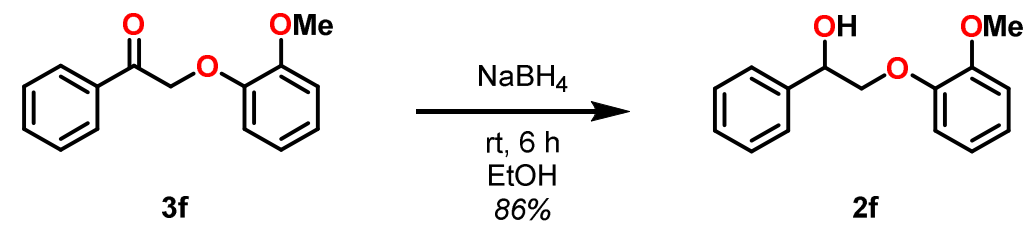

Synthesis of 2-(2-methoxyphenoxy)-1-phenylethan-1-ol (2f). A round bottom flask was charged with 2-(2-methoxyphenoxy)-1-phenylethan-1-one (3f, $0.750 \mathrm{~g}, 3.10 \mathrm{mmol})$ and $25 \mathrm{~mL}$ of EtOH was added. $\mathrm{NaBH}_{4}(0.141 \mathrm{~g}, 3.71 \mathrm{mmol})$ was added in one portion at room temperature. The resulting mixture was stirred at room temperature for $6 \mathrm{~h}$. The solution was then diluted with $\mathrm{H}_{2} \mathrm{O}(2 \mathrm{~mL})$ and the $\mathrm{pH}$ was adjusted to $\mathrm{pH} \mathrm{5-6}$ with $1 \mathrm{M} \mathrm{HCl}$. The resulting solution was stirred at room temperature for $1 \mathrm{~h}$ after which the aqueous phase was extracted with $\mathrm{Et}_{2} \mathrm{O}(3 \times 50 \mathrm{~mL})$. The combined organic extracts were washed with brine, dried over anhydrous $\mathrm{Na}_{2} \mathrm{SO}_{4}$, filtered and concentrated in vacuo. The residue was purified by column chromatography (hexanes/EtOAc $4: 1$ ) to give the product as a colorless oil $(0.650 \mathrm{~g}, 86 \%)$. Spectral data are consistent with those reported in the literature. ${ }^{\mathrm{S3}}$

${ }^{1} \mathrm{H}$ NMR $\left(500 \mathrm{MHz}, \mathrm{CDCl}_{3}\right): \delta 7.45(\mathrm{~d}, J=7.5 \mathrm{~Hz}, 2 \mathrm{H}), 7.38(\mathrm{t}, J=7.5 \mathrm{~Hz}, 2 \mathrm{H}), 7.32(\mathrm{t}, J=7.5 \mathrm{~Hz}, 1 \mathrm{H})$, 7.02-6.97 (m, 1H), 6.96-6.88 (m, 3H), $5.13(\mathrm{dd}, J=9.4,2.7 \mathrm{~Hz}, 1 \mathrm{H}), 4.18(\mathrm{dd}, J=10.0,2.7 \mathrm{~Hz}, 1 \mathrm{H})$, $3.99(\mathrm{t}, J=9.7 \mathrm{~Hz}, 1 \mathrm{H}), 3.88(\mathrm{~s}, 3 \mathrm{H}), 3.15(\mathrm{br} \mathrm{s}, 1 \mathrm{H})$.

${ }^{13} \mathrm{C}$ NMR (126 MHz, CDCl $): \delta$ 150.1, 148.1, 139.7, 128.6 (2C), 128.1, 126.4 (2C), 122.6, 121.2, 115.8, $112.1,76.3,72.4,55.9$.

HRMS (ESI): Calculated for $\mathrm{C}_{15} \mathrm{H}_{16} \mathrm{NaO}_{3}[\mathrm{M}+\mathrm{Na}]^{+}:$267.0992, found: 267.0991 .

$\mathbf{R}_{\mathrm{f}}($ hexanes/EtOAc 2:1) $=0.41$. 


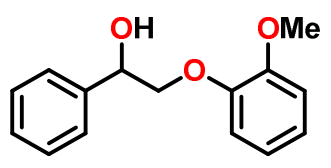

$2 f$

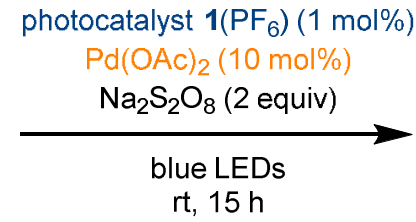

DMF

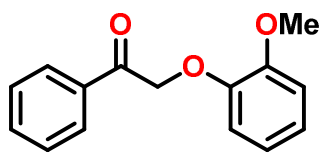

3f, $30 \%$

Oxidation of 2-(2-methoxyphenoxy)-1-phenylethan-1-ol (2f). Performed according to "Representative Procedure for Oxidation of Lignin Model Systems". A round bottom flask was charged with $\left[\operatorname{Ir}\left\{\mathrm{dF}\left(\mathrm{CF}_{3}\right) \mathrm{ppy}\right\}_{2}(\mathrm{dtbbpy})\right] \mathrm{PF}_{6}(3.0 \mu \mathrm{mol}, 3.3 \mathrm{mg}, 1 \mathrm{~mol} \%), \mathrm{Pd}(\mathrm{OAc})_{2}(0.030 \mathrm{mmol}, 6.7 \mathrm{mg}$, 10 mol\%), 2-(2-methoxyphenoxy)-1-phenylethan-1-ol (2f, $0.30 \mathrm{mmol}, 73 \mathrm{mg}), \mathrm{Na}_{2} \mathrm{~S}_{2} \mathrm{O}_{8}(0.60 \mathrm{mmol}$, $143 \mathrm{mg}, 2$ equiv) and DMF (4.5 mL). The resulting solution was degassed by repeated freeze-pumpthaw cycles ( 3 cycles) and the flask was back-filled with nitrogen. The reaction was then irradiated with a $4.4 \mathrm{~W}$ blue LED strip in a circle around the reaction flask (approximately $5 \mathrm{~cm}$ from the flask) and stirred at room temperature for $15 \mathrm{~h}$. After completion of the reaction, $\mathrm{CH}_{2} \mathrm{Cl}_{2}$ and $\mathrm{H}_{2} \mathrm{O}$ were added and the layers were separated. The aqueous layer was extracted with $\mathrm{CH}_{2} \mathrm{Cl}_{2}(3 \mathrm{x})$ and the combined organic layers were washed with $5 \%$ aq. LiCl (3x), brine (2x), dried over $\mathrm{Na}_{2} \mathrm{SO}_{4}$ and filtered before concentrating the solution in vacuo. The crude residue was purified by column chromatography (hexanes/EtOAc 4:1) to afford 2-(2-methoxyphenoxy)-1-phenylethan-1-one (3f) as a white solid (22 mg, 30\%). 
<smiles>COc1ccc(C(=O)COc2ccccc2OC)cc1</smiles>

3a

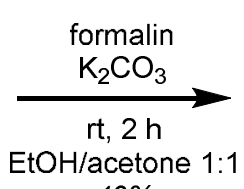
$49 \%$

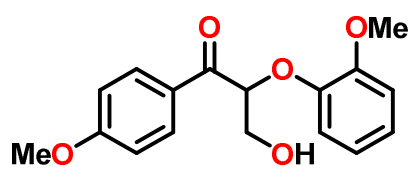

$5 a$

Synthesis of 3-hydroxy-2-(2-methoxyphenoxy)-1-(4-methoxyphenyl)propan-1-one (5a). To a solution of 2-(2-methoxyphenoxy)-1-(4-methoxyphenyl)ethan-1-one (3a, $0.700 \mathrm{~g}, 2.57 \mathrm{mmol}$ ) in EtOH/acetone (v:v 1:1, $25 \mathrm{~mL})$ containing $\mathrm{K}_{2} \mathrm{CO}_{3}(0.391 \mathrm{~g}, 2.83 \mathrm{mmol})$ was added formalin $(0.310 \mathrm{~mL}$, $4.16 \mathrm{mmol}$ ). The resulting mixture was stirred at room temperature for $2 \mathrm{~h}$ and then filtered, washed with acetone and concentrated in vacuo to give the crude product as an orange-pink oil. Purification by column chromatography (hexanes/EtOAc $1: 1)$ afforded the product as a colorless oil $(0.380 \mathrm{~g}$, 49\%). Spectral data are consistent with those reported in the literature. ${ }^{S 7}$

${ }^{1} \mathrm{H}$ NMR $\left(500 \mathrm{MHz}, \mathrm{CDCl}_{3}\right): \delta 8.07(\mathrm{~d}, J=8.8 \mathrm{~Hz}, 2 \mathrm{H}), 7.00(\mathrm{t}, J=7.8 \mathrm{~Hz}, 1 \mathrm{H}), 6.94(\mathrm{~d}, J=8.8 \mathrm{~Hz}, 2 \mathrm{H})$, 6.92-6.88 (m, 2H), $6.82(\mathrm{t}, J=7.8 \mathrm{~Hz}, 1 \mathrm{H}), 5.37(\mathrm{t}, J=5.3 \mathrm{~Hz}, 1 \mathrm{H}), 4.05(\mathrm{~d}, J=5.3 \mathrm{~Hz}, 2 \mathrm{H}), 3.87(\mathrm{~s}, 3 \mathrm{H})$, $3.86(\mathrm{~s}, 3 \mathrm{H}), 3.08$ (br s, 1H).

${ }^{13} \mathrm{C}$ NMR (126 MHz, CDCl $): \delta$ 195.1, 164.2, 150.7, 147.1, 131.4 (2C), 128.1, 123.8, 121.3, 118.9, 114.1 (2C), 112.4, 84.9, 63.7, 56.0, 55.7.

HRMS (ESI): Calculated for $\mathrm{C}_{17} \mathrm{H}_{19} \mathrm{O}_{5}[\mathrm{M}+\mathrm{H}]^{+}: 303.1227$, found: 303.1227 .

$\mathbf{R}_{\mathrm{f}}$ (hexanes/EtOAc 1:1) $=0.24$.<smiles>COc1ccc(C(=O)C(CO)Oc2ccccc2OC)cc1</smiles>

$5 a$

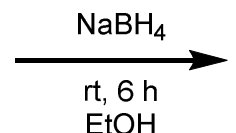

$79 \%$<smiles>COc1ccc(C(O)C(CO)Oc2ccccc2OC)cc1</smiles>

$4 a$

Synthesis of 2-(2-methoxyphenoxy)-1-(4-methoxyphenyl)propane-1,3-diol (4a). A round bottom flask was charged with 3-hydroxy-2-(2-methoxyphenoxy)-1-(4-methoxyphenyl)propan-1-one (5a, $0.210 \mathrm{~g}, 0.695 \mathrm{mmol})$ and EtOH $(25 \mathrm{~mL})$ was added. $\mathrm{NaBH}_{4}(0.032 \mathrm{~g}, 0.854 \mathrm{mmol})$ was subsequently 
added in one portion at room temperature and the resulting mixture was stirred at room temperature for $6 \mathrm{~h}$. The solution was diluted with $\mathrm{H}_{2} \mathrm{O}(20 \mathrm{~mL})$ and the $\mathrm{pH}$ was adjusted to $\mathrm{pH}$ 5-6 with $1 \mathrm{M} \mathrm{HCl}$. The resulting solution was stirred at room temperature for $1 \mathrm{~h}$ after which the aqueous phase was extracted with $\mathrm{Et}_{2} \mathrm{O}(3 \times 30 \mathrm{~mL})$. The combined organic extracts were washed with brine, dried over anhydrous $\mathrm{Na}_{2} \mathrm{SO}_{4}$, filtered and concentrated in vacuo. The residue was purified by column chromatography (hexanes/EtOAc 2:1) to give the product as a mixture of diastereomers (erythro:threo 2:1) as a colorless oil (0.170 g, 79\%).

Major diastereomer (erythro) ${ }^{\mathrm{s7}, \mathrm{s8}}$

${ }^{1} \mathrm{H}$ NMR (500 MHz, $\left.\mathrm{CDCl}_{3}\right): \delta 7.31(\mathrm{~d}, J=7.4 \mathrm{~Hz}, 2 \mathrm{H}), 7.08-7.03(\mathrm{~m}, 1 \mathrm{H}), 6.96-6.86(\mathrm{~m}, 5 \mathrm{H}), 4.99(\mathrm{~d}, J=$ $5.0 \mathrm{~Hz}, 1 \mathrm{H}), 4.15(\mathrm{ddd}, J=5.9,5.0,3.3 \mathrm{~Hz}, 1 \mathrm{H}), 3.90(\mathrm{dd}, J=12.2,5.9 \mathrm{~Hz}, 1 \mathrm{H}), 3.87(\mathrm{~s}, 3 \mathrm{H}), 3.79(\mathrm{~s}, 3 \mathrm{H})$, $3.65(\mathrm{dd}, J=12.2,3.3 \mathrm{~Hz}, 1 \mathrm{H}), 2.84(\mathrm{br} \mathrm{s}, 1 \mathrm{H})$.

${ }^{13} \mathrm{C}$ NMR (126 MHz, $\left.\mathrm{CDCl}_{3}\right): \delta 159.4,151.6,147.4,132.4,127.5$ (2C), 124.3, 121.8, 121.2, $114.1(2 \mathrm{C})$, $112.7,87.4,73.0,61.0,56.2,55.5$.

\section{Minor diastereomer $(\text { threo })^{\mathrm{S7}}$}

${ }^{1}$ H NMR (500 MHz, CDCl $): \delta 7.36(\mathrm{~d}, J=7.8 \mathrm{~Hz}, 2 \mathrm{H}), 7.13(\mathrm{~d}, J=7.8 \mathrm{~Hz}, 1 \mathrm{H}), 7.08-7.03(\mathrm{~m}, 1 \mathrm{H}), 6.96-$ $6.86(\mathrm{~m}, 4 \mathrm{H}), 4.99(\mathrm{~d}, J=3.3 \mathrm{~Hz}, 1 \mathrm{H}), 4.05-4.01(\mathrm{~m}, 1 \mathrm{H}), 3.90(\mathrm{~s}, 3 \mathrm{H}), 3.80(\mathrm{~s}, 3 \mathrm{H}), 3.60(\mathrm{dd}, J=12.5$, $3.2 \mathrm{~Hz}, 1 \mathrm{H}), 3.45(\mathrm{dd}, J=12.5,3.9 \mathrm{~Hz}, 1 \mathrm{H}), 2.84(\mathrm{br} \mathrm{s}, 1 \mathrm{H})$.

${ }^{13} \mathrm{C}$ NMR (126 MHz, $\left.\mathrm{CDCl}_{3}\right): \delta 159.8,151.9,148.1,132.1,128.5(2 \mathrm{C}), 124.3,121.9,121.2,114.2(2 \mathrm{C})$, $112.6,89.5,73.9,61.3,56.2,55.5$.

HRMS (ESI): Calculated for $\mathrm{C}_{17} \mathrm{H}_{20} \mathrm{NaO}_{5}[\mathrm{M}+\mathrm{Na}]^{+}: 327.1203$, found: 327.1191.

$\mathbf{R}_{\mathbf{f}}($ hexanes/EtOAc 1:1) $=0.19$. 


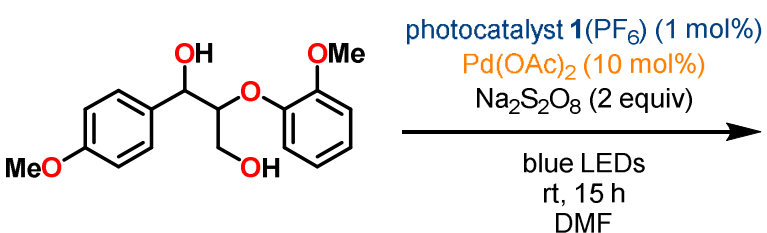

$4 a$

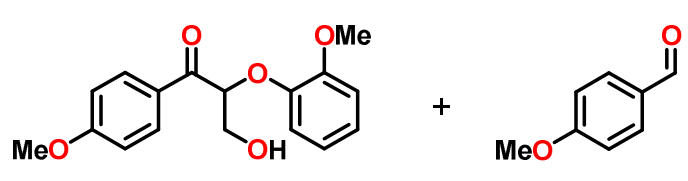

5 a, $43 \%$

6a, $19 \%$

Oxidative cleavage of 2-(2-methoxyphenoxy)-1-(4-methoxyphenyl)propane-1,3-diol (4a). Performed according to "Representative Procedure for Oxidation of Lignin Model Systems". A round bottom flask was charged with $\left[\operatorname{Ir}\left\{\mathrm{dF}\left(\mathrm{CF}_{3}\right) \mathrm{ppy}\right\}_{2}(\mathrm{dtbbpy})\right] \mathrm{PF}_{6}(3.0 \mu \mathrm{mol}, 3.3 \mathrm{mg}, 1 \mathrm{~mol} \%), \mathrm{Pd}(\mathrm{OAc})_{2}$ (0.030 mmol, $6.7 \mathrm{mg}, 10 \mathrm{~mol} \%), 2$-(2-methoxyphenoxy)-1-(4-methoxyphenyl)propane-1,3-diol (4a, $0.30 \mathrm{mmol}, 91 \mathrm{mg}), \mathrm{Na}_{2} \mathrm{~S}_{2} \mathrm{O}_{8}(0.60 \mathrm{mmol}, 143 \mathrm{mg}, 2$ equiv) and $\mathrm{DMF}(4.5 \mathrm{~mL})$. The resulting solution was degassed by repeated freeze-pump-thaw cycles ( 3 cycles) and the flask was back-filled with nitrogen. The reaction was then irradiated with a $4.4 \mathrm{~W}$ blue LED strip in a circle around the reaction flask (approximately $5 \mathrm{~cm}$ from the flask) and stirred at room temperature for $15 \mathrm{~h}$. After completion of the reaction, $\mathrm{CH}_{2} \mathrm{Cl}_{2}$ and $\mathrm{H}_{2} \mathrm{O}$ were added and the layers were separated. The aqueous layer was extracted with $\mathrm{CH}_{2} \mathrm{Cl}_{2}(3 \mathrm{x})$ and the combined organic layers were washed with $5 \%$ aq. $\mathrm{LiCl}(3 \mathrm{x})$, brine (2x), dried over $\mathrm{Na}_{2} \mathrm{SO}_{4}$ and filtered before concentrating the solution in vacuo. The crude residue was purified by column chromatography (hexanes/EtOAc 2:1) to afford 3-hydroxy-2-(2methoxyphenoxy)-1-(4-methoxyphenyl)propan-1-one (5a, $39 \mathrm{mg}, 43 \%$ ) and 4-methoxybenzaldehyde (6a, $7.8 \mathrm{mg}, 19 \%)$.

\section{4-Methoxybenzaldehyde $(6 a)^{59}$}

${ }^{1} \mathrm{H}$ NMR $\left(500 \mathrm{MHz}, \mathrm{CDCl}_{3}\right): \delta 9.88(\mathrm{~s}, 1 \mathrm{H}), 7.84(\mathrm{~d}, J=8.7,2 \mathrm{H}), 7.00(\mathrm{~d}, J=8.7,2 \mathrm{H}), 3.89(\mathrm{~s}, 3 \mathrm{H})$.

${ }^{13}$ C NMR (126 MHz, CDCl $)$ ): $\delta$ 191.0, 164.7, 132.1 (2C), 130.1, 114.4 (2C), 55.7.

HRMS (ESI): Calculated for $\mathrm{C}_{8} \mathrm{H}_{9} \mathrm{O}_{2}[\mathrm{M}+\mathrm{H}]^{+}:$: 137.0597, found: 137.0596 .

$\mathbf{R}_{\mathbf{f}}($ hexanes/EtOAc 1:1) $=0.92$. 

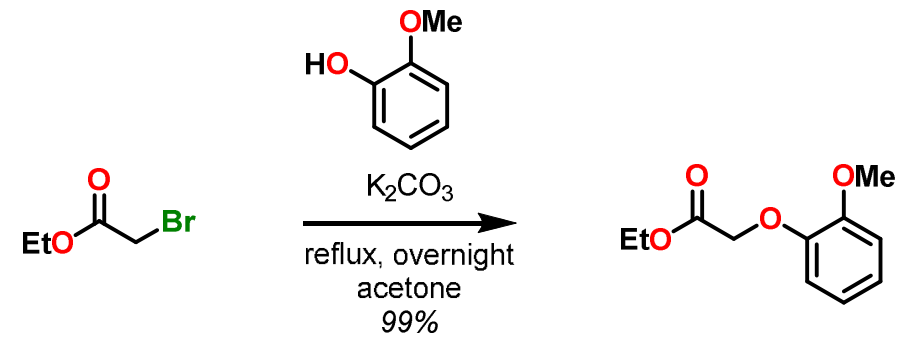

Synthesis of ethyl 2-(2-methoxyphenoxy)acetate. A flame-dried round bottom flask equipped with a reflux condenser was charged with ethyl 2-bromoacetate (4.75 g, 28.4 mmol), guaiacol (3.53 g, 28.4 $\mathrm{mmol}), \mathrm{K}_{2} \mathrm{CO}_{3}(3.93 \mathrm{~g}, 28.4 \mathrm{mmol})$ and acetone $(140 \mathrm{~mL})$. The resulting mixture was heated to reflux overnight. After cooling to room temperature, the reaction mixture was filtered, washed with acetone and evaporated under reduced pressure to provide the title compound as a colorless oil (5.90 g, 99\%). Spectral data are consistent with those reported in the literature. ${ }^{\text {s10 }}$

${ }^{1}$ H NMR (400 MHz, $\left.\mathrm{CDCl}_{3}\right): \delta 6.97(\mathrm{ddd}, J=7.8,7.2,1.8 \mathrm{~Hz}, 1 \mathrm{H}), 6.92-6.81(\mathrm{~m}, 3 \mathrm{H}), 4.68(\mathrm{~s}, 2 \mathrm{H}), 4.25$ (q, J= $7.3 \mathrm{~Hz}, 2 \mathrm{H}), 3.88(\mathrm{~s}, 3 \mathrm{H}), 1.28(\mathrm{t}, J=7.3 \mathrm{~Hz}, 3 \mathrm{H})$.

${ }^{13} \mathrm{C}$ NMR (126 MHz, CDCl $): \delta$ 169.2, 150.2, 147.8, 122.8, 121.0, 115.4, 112.8, 67.1, 61.2, 56.2, 14.3.

HRMS (ESI): Calculated for $\mathrm{C}_{11} \mathrm{H}_{14} \mathrm{NaO}_{4}[\mathrm{M}+\mathrm{Na}]^{+}: 233.0784$, found: 233.0784 .

$\mathbf{R}_{\mathbf{f}}($ hexanes/EtOAc 2:1) $=0.58$.<smiles>CCOC(=O)COc1ccccc1OC</smiles>

1) LiHMDS

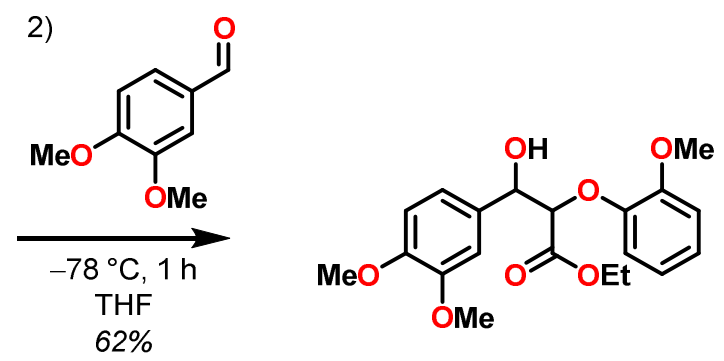

Synthesis of ethyl 3-(3,4-dimethoxyphenyl)-3-hydroxy-2-(2-methoxyphenoxy)propanoate. To a flame-dried and argon flushed round bottom flask containing LiHMDS (14.6 mmol, $14.6 \mathrm{~mL}, 1.0 \mathrm{M}$ in THF) in THF (10 mL) was slowly added a solution of ethyl 2-(2-methoxyphenoxy)acetate (2.78 g, 13.2 
$\mathrm{mmol})$ in THF $(5 \mathrm{~mL})$ at $-78{ }^{\circ} \mathrm{C}$. This was followed by addition of 3,4-dimethoxybenzaldehyde $(2.20 \mathrm{~g}$, $13.2 \mathrm{mmol})$ in THF $(5 \mathrm{~mL})$ while maintaining the temperature at $-78{ }^{\circ} \mathrm{C}$. The resulting mixture was stirred at this temperature for $1 \mathrm{~h}$ after which a saturated aqueous $\mathrm{NH}_{4} \mathrm{Cl}$ solution was added to quench the reaction. EtOAc was subsequently added and the phases were separated. The aqueous phase was further extracted with EtOAc and the combined organic extracts were dried over $\mathrm{Na}_{2} \mathrm{SO}_{4}$, filtered and concentrated under reduced pressure. The crude product was purified by column chromatography (hexanes/EtOAc 2:1) to afford the product as a mixture of diastereomers (erythro:threo 10:1) as a white solid (3.07 g, 62\%).

\section{Major diastereomer (erythro) $)^{\mathrm{s11,s12}}$}

${ }^{1} \mathrm{H}$ NMR $\left(500 \mathrm{MHz}, \mathrm{CDCl}_{3}\right): \delta 7.06(\mathrm{~d}, J=1.8 \mathrm{~Hz}, 1 \mathrm{H}), 7.04-6.96(\mathrm{~m}, 2 \mathrm{H}), 6.93-6.88(\mathrm{~m}, 2 \mathrm{H}), 6.86-6.81$ $(\mathrm{m}, 2 \mathrm{H}), 5.14(\mathrm{~d}, J=4.9 \mathrm{~Hz}, 1 \mathrm{H}), 4.73(\mathrm{~d}, J=4.9 \mathrm{~Hz}, 1 \mathrm{H}), 4.14(\mathrm{q}, J=7.1 \mathrm{~Hz}, 2 \mathrm{H}), 3.88(\mathrm{~s}, 3 \mathrm{H}), 3.86(\mathrm{~s}$, $3 \mathrm{H}), 3.86(\mathrm{~s}, 3 \mathrm{H}), 3.73(\mathrm{br} \mathrm{s}, 1 \mathrm{H}), 1.15(\mathrm{t}, J=7.1 \mathrm{~Hz}, 3 \mathrm{H})$.

${ }^{13}$ C NMR (126 MHz, $\left.\mathrm{CDCl}_{3}\right): \delta 169.5,151.0,149.3,149.2,147.7,132.2,124.0,121.4,119.7,119.2$, $112.9,111.4,110.9,84.1,74.1,61.3,56.2,56.15,56.1,14.2$.

\section{Minor diastereomer (threo $)^{\mathrm{s11}}$}

${ }^{1} \mathrm{H}$ NMR (500 MHz, CDCl $)$ : $\delta$ 7.04-6.96 (m, 2H), 6.93-6.88 (m, 3H), 6.86-6.81 (m, 2H), $5.06(\mathrm{~d}, J=7.2$ $\mathrm{Hz}, 1 \mathrm{H}), 4.48(\mathrm{~d}, J=7.2 \mathrm{~Hz}, 1 \mathrm{H}), 4.05(\mathrm{t}, J=7.3 \mathrm{~Hz}, 2 \mathrm{H}), 3.87(\mathrm{~s}, 3 \mathrm{H}), 3.86(\mathrm{~s}, 3 \mathrm{H}), 3.86(\mathrm{~s}, 3 \mathrm{H}), 3.73(\mathrm{br}$ $s, 1 \mathrm{H}), 1.06(\mathrm{t}, J=7.3 \mathrm{~Hz}, 3 \mathrm{H})$.

${ }^{13}$ C NMR (126 MHz, CDCl $): \delta 169.5,150.8,149.6,149.4,147.7,131.7,124.1,121.3,119.9,118.7$, $112.8,111.5,110.8,85.7,75.1,61.3,56.2,56.15,56.1,14.1$.

HRMS (ESI): Calculated for $\mathrm{C}_{20} \mathrm{H}_{24} \mathrm{NaO}_{7}[\mathrm{M}+\mathrm{Na}]^{+}: 399.1414$, found: 399.1413 .

$\mathbf{R}_{\mathbf{f}}($ hexanes/EtOAc 1:2) $=0.58$. 

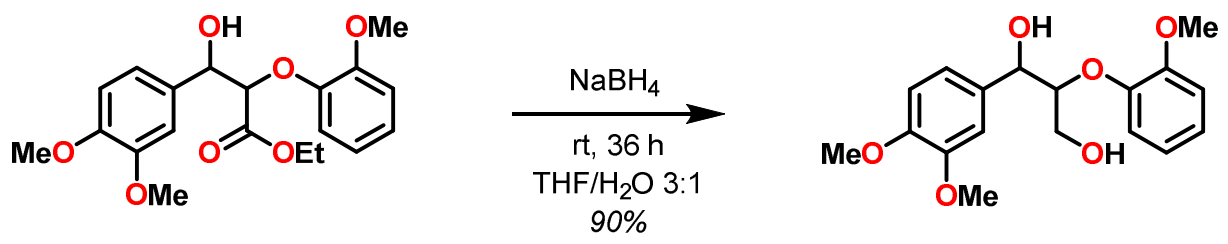

$4 \mathbf{b}$

Synthesis of 1-(3,4-dimethoxyphenyl)-2-(2-methoxyphenoxy)propane-1,3-diol (4b). $\mathrm{NaBH}_{4}(120.6$ $\mathrm{mg}, 3.18 \mathrm{mmol}$ ) was added to a solution of ethyl 3-(3,4-dimethoxyphenyl)-3-hydroxy-2-(2methoxyphenoxy)propanoate $(200 \mathrm{mg}, 0.532 \mathrm{mmol})$ in $\mathrm{THF} / \mathrm{H}_{2} \mathrm{O}(3: 1,5.6 \mathrm{~mL})$. The resulting mixture was stirred at room temperature for $36 \mathrm{~h}$. The reaction was diluted with $\mathrm{H}_{2} \mathrm{O}$ and $\mathrm{CH}_{2} \mathrm{Cl}_{2}$. The phases were separated and the aqueous phase was additionally extracted with $\mathrm{CH}_{2} \mathrm{Cl}_{2}$ (3x). The combined organic extracts were washed with brine, dried over $\mathrm{Na}_{2} \mathrm{SO}_{4}$, filtered and evaporated under reduced pressure to give the product as mixture of diastereomers (erythro:threo 10:1) as a viscous colorless oil (160 mg, 90\%).

Major diastereomer (erythro) $)^{\mathrm{s11,s12}}$

${ }^{1} \mathrm{H}$ NMR $\left(500 \mathrm{MHz}, \mathrm{CDCl}_{3}\right): \delta$ 7.08-7.02 (m, 1H), 6.99-6.87 (m, 5H), 6.84-6.80 (m, 1H), $4.97(\mathrm{~d}, J=4.7$ $\mathrm{Hz}, 1 \mathrm{H}), 4.15(\mathrm{ddd}, J=5.9,4.7,3.4 \mathrm{~Hz}, 1 \mathrm{H}), 3.91(\mathrm{dd}, J=12.2,5.9 \mathrm{~Hz}, 1 \mathrm{H}), 3.86(\mathrm{~s}, 6 \mathrm{H}), 3.86(\mathrm{~s}, 3 \mathrm{H})$, $3.65(\mathrm{dd}, J=12.2,3.4 \mathrm{~Hz}, 1 \mathrm{H}), 2.88(\mathrm{br} \mathrm{s}, 1 \mathrm{H})$.

${ }^{13} \mathrm{C}$ NMR (126 MHz, CDCl $): \delta 151.6,149.0,148.5,147.0,132.7,124.2,121.7,120.8,118.5,112.2$, $111.1,109.3,87.3,72.8,60.8,56.0(2 C), 55.9$.

\section{Minor diastereomer (threo $)^{\mathrm{s11,512}}$}

${ }^{1} \mathrm{H}$ NMR (500 MHz, $\left.\mathrm{CDCl}_{3}\right): \delta 7.12(\mathrm{dd}, J=7.9,1.5 \mathrm{~Hz}, 1 \mathrm{H}), 7.08-7.02(\mathrm{~m}, 1 \mathrm{H}), 6.99-6.87(\mathrm{~m}, 4 \mathrm{H})$, $6.84-6.80(\mathrm{~m}, 1 \mathrm{H}), 4.98(\mathrm{~d}, J=7.6 \mathrm{~Hz}, 1 \mathrm{H}), 4.02(\mathrm{ddd}, J=7.6,3.8,3.3 \mathrm{~Hz}, 1 \mathrm{H}), 3.89(\mathrm{~s}, 3 \mathrm{H}), 3.87(\mathrm{~s}, 6 \mathrm{H})$, $3.62(\mathrm{dd}, J=12.6,3.3 \mathrm{~Hz}, 1 \mathrm{H}), 3.47(\mathrm{dd}, J=12.6,3.8 \mathrm{~Hz}, 1 \mathrm{H}), 2.88(\mathrm{br} \mathrm{s}, 1 \mathrm{H})$.

${ }^{13} \mathrm{C}$ NMR (126 MHz, CDCl $): \delta 151.3,149.1,148.9,147.7,132.2,124.3,121.8,121.0,119.7,112.2$, $111.1,110.0,89.4,73.9,61.1,56.0(2 \mathrm{C}), 55.9$. 
HRMS (ESI): Calculated for $\mathrm{C}_{18} \mathrm{H}_{22} \mathrm{NaO}_{6}[\mathrm{M}+\mathrm{Na}]^{+}: 357.1309$, found: 357.1306 .

$\mathbf{R}_{\mathbf{f}}($ hexanes/EtOAc 1:3) $=0.35$.

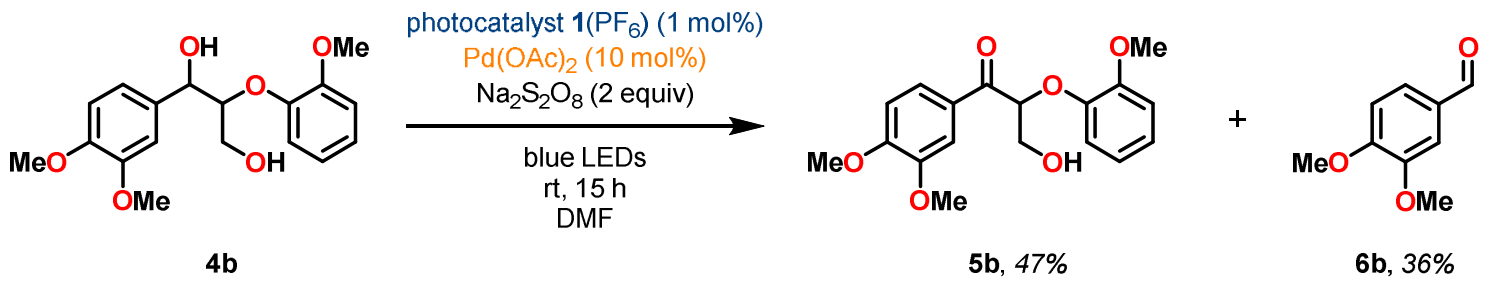

Oxidation of 1-(3,4-dimethoxyphenyl)-2-(2-methoxyphenoxy)propane-1,3-diol (4b). Performed according to "Representative Procedure for Oxidation of Lignin Model Systems". A round bottom flask was charged with $\left[\operatorname{Ir}\left\{\mathrm{dF}\left(\mathrm{CF}_{3}\right) \mathrm{ppy}\right\}_{2}(\mathrm{dtbbpy})\right] P F_{6}(3.0$ ?mol, $3.3 \mathrm{mg}, 1 \mathrm{~mol} \%), \mathrm{Pd}(\mathrm{OAc})_{2}(0.030$ mmol, 6.7 mg, 10 mol\%), 1-(3,4-dimethoxyphenyl)-2-(2-methoxyphenoxy)propane-1,3-diol (4b, 0.30 mmol, $100 \mathrm{mg}), \mathrm{Na}_{2} \mathrm{~S}_{2} \mathrm{O}_{8}(0.60 \mathrm{mmol}, 143 \mathrm{mg}, 2$ equiv) and DMF (4.5 mL). The resulting solution was degassed by repeated freeze-pump-thaw cycles (3 cycles) and the flask was back-filled with nitrogen. The reaction was then irradiated with a $4.4 \mathrm{~W}$ blue LED strip in a circle around the reaction flask (approximately $5 \mathrm{~cm}$ from the flask) and stirred at room temperature for $15 \mathrm{~h}$. After completion of the reaction, $\mathrm{CH}_{2} \mathrm{Cl}_{2}$ and $\mathrm{H}_{2} \mathrm{O}$ were added and the layers were separated. The aqueous layer was extracted with $\mathrm{CH}_{2} \mathrm{Cl}_{2}(3 x)$ and the combined organic layers were washed with $5 \%$ aq. $\mathrm{LiCl}(3 \mathrm{x})$, brine (2x), dried over $\mathrm{Na}_{2} \mathrm{SO}_{4}$ and filtered before concentrating the solution in vacuo. The crude residue was purified by column chromatography (hexanes/EtOAc 1:1) to afford 1-(3,4-dimethoxyphenyl)-3hydroxy-2-(2-methoxyphenoxy)propan-1-one (5b, 47 mg, 47\%) and 3,4-dimethoxybenzaldehyde (6b, $18 \mathrm{mg}, 36 \%)$ as white solids.

\section{1-(3,4-Dimethoxyphenyl)-3-hydroxy-2-(2-methoxyphenoxy)propan-1-one (5b) $)^{\mathrm{s13}}$}

${ }^{1}$ H NMR (500 MHz, $\left.\mathrm{CDCl}_{3}\right): \delta 7.75(\mathrm{dd}, J=8.5,1.9 \mathrm{~Hz}, 1 \mathrm{H}), 7.61(\mathrm{~d}, J=1.9 \mathrm{~Hz}, 1 \mathrm{H}), 6.99(\mathrm{td}, J=7.7,1.5$ $\mathrm{Hz}, 1 \mathrm{H}), 6.91-6.86(\mathrm{~m}, 3 \mathrm{H}), 6.81(\mathrm{td}, J=7.7,1.6 \mathrm{~Hz}, 1 \mathrm{H}), 5.40(\mathrm{t}, J=5.3 \mathrm{~Hz}, 1 \mathrm{H}), 4.07(\mathrm{~d}, J=5.3 \mathrm{~Hz}, 2 \mathrm{H})$, $3.94(\mathrm{~s}, 3 \mathrm{H}), 3.91(\mathrm{~s}, 3 \mathrm{H}), 3.84(\mathrm{~s}, 3 \mathrm{H}), 3.19$ (br s, 1H). 
${ }^{13}$ C NMR (126 MHz, CDCl 3$): \delta 195.3,154.3,150.9,149.5,147.4,128.6,123.9,123.8,121.4,119.0$, $112.8,111.7,110.6,84.9,63.9,56.3,56.2,56.1$.

HRMS (ESI): Calculated for $\mathrm{C}_{18} \mathrm{H}_{21} \mathrm{O}_{6}[\mathrm{M}+\mathrm{H}]^{+}: 333.1333$, found: 333.1333 .

$\mathbf{R}_{\mathrm{f}}($ hexanes/EtOAc 1:2) $=0.22$.

\section{3,4-Dimethoxybenzaldehyde $(6 b)^{514,515}$}

${ }^{1} \mathrm{H}$ NMR $\left(500 \mathrm{MHz}, \mathrm{CDCl}_{3}\right): \delta 9.80(\mathrm{~s}, 1 \mathrm{H}), 7.41(\mathrm{dd}, J=8.2,1.7 \mathrm{~Hz}, 1 \mathrm{H}), 7.36(\mathrm{~d}, J=1.7 \mathrm{~Hz}, 1 \mathrm{H}), 6.94(\mathrm{~d}$, $J=8.2 \mathrm{~Hz}, 1 \mathrm{H}), 3.92(\mathrm{~s}, 3 \mathrm{H}), 3.89(\mathrm{~s}, 3 \mathrm{H})$.

${ }^{13} \mathrm{C}$ NMR (126 MHz, $\left.\mathrm{CDCl}_{3}\right): \delta$ 190.9, 154.5, 149.6, 130.1, 126.9, 110.4, 108.9, 56.2, 56.0.

HRMS (ESI): Calculated for $\mathrm{C}_{9} \mathrm{H}_{11} \mathrm{O}_{3}[\mathrm{M}+\mathrm{H}]^{+}:$167.0703, found: 167.0700 .

$\mathbf{R}_{\mathbf{f}}($ hexanes/EtOAc 1:1) $=0.61$.
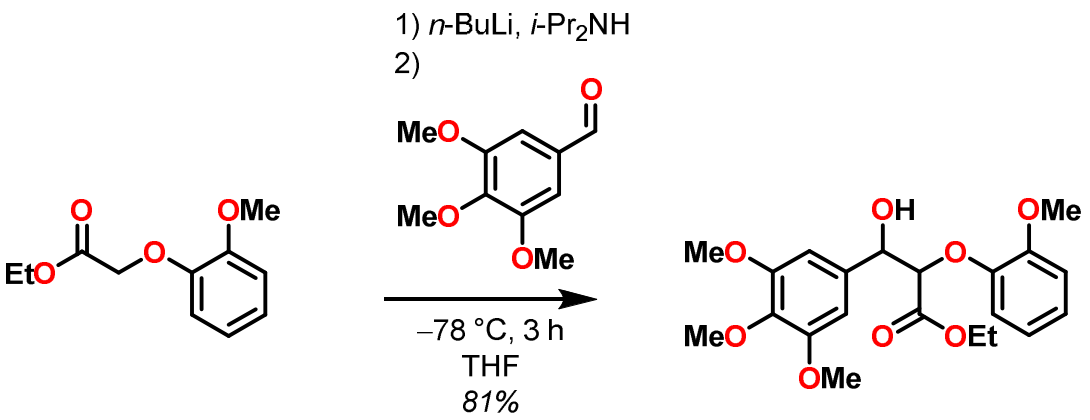

Synthesis of ethyl 3-hydroxy-2-(2-methoxyphenoxy)-3-(3,4,5-trimethoxyphenyl)propanoate. $n$-BuLi (2.92 $\mathrm{mL}, 7.29 \mathrm{mmol}, 2.5 \mathrm{M}$ in hexanes) was added to a flame-dried round bottom flask containing a solution of diisopropylamine $(1.02 \mathrm{~mL}, 7.29 \mathrm{mmol})$ in THF $(10 \mathrm{~mL})$ at $-78^{\circ} \mathrm{C}$. The resulting solution was stirred at this temperature for $30 \mathrm{~min}$. To this mixture was added a THF solution ( $5 \mathrm{~mL}$ ) of ethyl 2-(2-methoxyphenoxy)acetate $(1.39 \mathrm{~g}, 6.63 \mathrm{mmol})$ and the resulting solution was stirred for $1 \mathrm{~h}$. This was followed by the addition of 3,4,5-trimethoxybenzaldehyde $(1.30 \mathrm{~g}, 6.63 \mathrm{mmol})$ in THF $(5 \mathrm{~mL})$. The resulting mixture was stirred for $3 \mathrm{~h}$ while maintaining the temperature at $-78{ }^{\circ} \mathrm{C}$. Subsequently, the mixture was diluted with $\mathrm{H}_{2} \mathrm{O}$ and extracted with EtOAc. The combined organic extracts were dried 
over $\mathrm{Na}_{2} \mathrm{SO}_{4}$, filtered and evaporated in vacuo to give a yellow oily residue. This residue was subjected to column chromatography (hexanes/EtOAc 3:1 to 1:1) to yield the product as a mixture of diastereomers (erythro:threo 4:1) as a light yellow viscous oil (2.18 g, 81\%).

\section{Major diastereomer (erythro) ${ }^{58}$}

${ }^{1} \mathrm{H}$ NMR $\left(500 \mathrm{MHz}, \mathrm{CDCl}_{3}\right): \delta 7.03-6.99(\mathrm{~m}, 1 \mathrm{H}), 6.92-6.88(\mathrm{~m}, 2 \mathrm{H}), 6.88-6.81(\mathrm{~m}, 1 \mathrm{H}), 6.71(\mathrm{~s}, 2 \mathrm{H})$, $5.13(\mathrm{t}, J=5.4 \mathrm{~Hz}, 1 \mathrm{H}), 4.72(\mathrm{~d}, J=5.4 \mathrm{~Hz}, 1 \mathrm{H}), 4.15(\mathrm{q}, J=7.1 \mathrm{~Hz}, 2 \mathrm{H}), 3.85(\mathrm{~s}, 9 \mathrm{H}), 3.82(\mathrm{~s}, 3 \mathrm{H}), 1.16$ $(\mathrm{t}, J=7.1 \mathrm{~Hz}, 3 \mathrm{H})$.

${ }^{13} \mathrm{C}$ NMR (126 MHz, $\left.\mathrm{CDCl}_{3}\right): \delta$ 169.5, 153.1 (2C), 150.6, 147.3, 137.8, 134.9, 124.0, 121.2, 118.7, 112.4, $104.1(C), 83.7,74.2,61.4,60.9,56.2(2 C), 55.9,14.2$.

\section{Minor diastereomer (threo)}

${ }^{1} \mathrm{H}$ NMR $\left(500 \mathrm{MHz}, \mathrm{CDCl}_{3}\right): \delta$ 7.03-6.99 $(\mathrm{m}, 1 \mathrm{H}), 6.92-6.88(\mathrm{~m}, 1 \mathrm{H}), 6.88-6.81(\mathrm{~m}, 2 \mathrm{H}), 6.65(\mathrm{~s}, 2 \mathrm{H})$, $5.04(\mathrm{dd}, J=6.8,2.1 \mathrm{~Hz}, 1 \mathrm{H}), 4.48(\mathrm{~d}, J=6.8 \mathrm{~Hz}, 1 \mathrm{H}), 4.07(\mathrm{q}, J=7.1 \mathrm{~Hz}, 2 \mathrm{H}), 3.86(\mathrm{~s}, 3 \mathrm{H}), 3.84(\mathrm{~s}, 6 \mathrm{H})$, $3.82(\mathrm{~s}, 3 \mathrm{H}), 1.08(\mathrm{t}, J=7.1 \mathrm{~Hz}, 3 \mathrm{H})$.

${ }^{13} \mathrm{C}$ NMR (126 MHz, CDCl $)$ ): $\delta$ 169.6, 153.3 (2C), 150.5, 147.4, 138.1, 133.9, 124.1, 121.2, 118.3, 112.4, $104.2(2 \mathrm{C}), 85.4,75.3,61.4,60.9,56.2(2 \mathrm{C}), 55.9,14.1$.

HRMS (ESI): Calculated for $\mathrm{C}_{21} \mathrm{H}_{26} \mathrm{NaO}_{8}[\mathrm{M}+\mathrm{Na}]^{+}:$429.1520, found: 429.1517. $\mathbf{R}_{\mathbf{f}}($ hexanes/EtOAc 1:1) $=0.32$. 

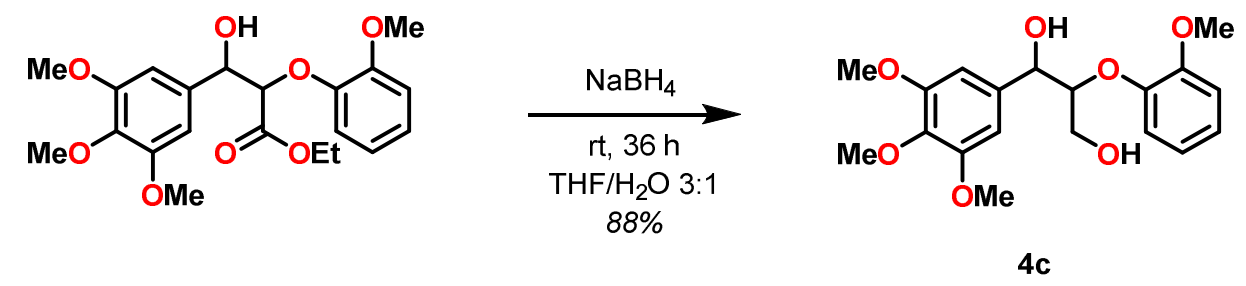

Synthesis of 2-(2-methoxyphenoxy)-1-(3,4,5-trimethoxyphenyl)propane-1,3-diol (4c). $\mathrm{NaBH}_{4}$ (142 $\mathrm{mg}, 3.74 \mathrm{mmol})$ was added to a solution of ethyl 3-hydroxy-2-(2-methoxyphenoxy)-3-(3,4,5trimethoxyphenyl)propanoate $(260 \mathrm{mg}, 0.640 \mathrm{mmol})$ in $\mathrm{THF} / \mathrm{H}_{2} \mathrm{O}(3: 1,8 \mathrm{~mL})$. The resulting mixture was stirred at room temperature for $36 \mathrm{~h}$. The reaction was diluted with $\mathrm{H}_{2} \mathrm{O}$ and $\mathrm{CH}_{2} \mathrm{Cl}_{2}$. The phases were separated and the aqueous phase was additionally extracted with $\mathrm{CH}_{2} \mathrm{Cl}_{2}$ (3x). The combined organic extracts were washed with brine, dried over $\mathrm{Na}_{2} \mathrm{SO}_{4}$, filtered and evaporated under reduced pressure to give the product as a mixture of diastereomers (erythro:threo 4:1) as a viscous colorless oil (200 mg, 88\%).

Major diastereomer (erythro) $)^{55,58,513}$

${ }^{1} \mathrm{H}$ NMR $\left(500 \mathrm{MHz}, \mathrm{CDCl}_{3}\right): \delta 7.09-7.04(\mathrm{~m}, 1 \mathrm{H}), 6.99-6.90(\mathrm{~m}, 3 \mathrm{H}), 6.61(\mathrm{~s}, 2 \mathrm{H}), 4.96(\mathrm{~d}, J=4.8 \mathrm{~Hz}$, 1H), 4.16 (ddd, $J=6.1,4.8,3.3 \mathrm{~Hz}, 1 \mathrm{H}), 3.92(\mathrm{dd}, J=12.3,6.1 \mathrm{~Hz}, 1 \mathrm{H}), 3.88(\mathrm{~s}, 3 \mathrm{H}), 3.84(\mathrm{~s}, 6 \mathrm{H}), 3.82$ (s, 3H), $3.66(\mathrm{dd}, J=12.3,3.3 \mathrm{~Hz}, 1 \mathrm{H}), 2.71(\mathrm{br} \mathrm{s}, 1 \mathrm{H})$.

${ }^{13} \mathrm{C}$ NMR (126 MHz, CDCl $)$ ): $\delta 153.4$ (2C), 151.7, 146.9, 137.5, 135.6, 124.4, 121.8, 121.1, 112.3, 103.1 (2C), 87.4, 73.0, 61.0, 60.9, $56.3(2 \mathrm{C}), 56.0$.

\section{Minor diastereomer (threo) $)^{55,513}$}

${ }^{1} \mathrm{H}$ NMR $\left(500 \mathrm{MHz}, \mathrm{CDCl}_{3}\right): \delta 7.11(\mathrm{dd}, J=7.8,1.3 \mathrm{~Hz}, 1 \mathrm{H}), 7.09-7.04(\mathrm{~m}, 1 \mathrm{H}), 6.99-6.90(\mathrm{~m}, 2 \mathrm{H}), 6.68$ (s, 2H), 4.97 (d, $J=7.2 \mathrm{~Hz}, 1 \mathrm{H}$ ), 4.02 (ddd, $J=7.2,3.7,3.3 \mathrm{~Hz}, 1 \mathrm{H}), 3.91(\mathrm{~s}, 3 \mathrm{H}), 3.86(\mathrm{~s}, 6 \mathrm{H}), 3.83(\mathrm{~s}$, $3 \mathrm{H}), 3.68-3.64(\mathrm{~m}, 1 \mathrm{H}), 3.51(\mathrm{dd}, J=12.5,3.7 \mathrm{~Hz}, 1 \mathrm{H}), 2.71(\mathrm{br} \mathrm{s}, 1 \mathrm{H})$.

${ }^{13} \mathrm{C}$ NMR (126 MHz, CDCl 3 ): $\delta 153.4$ (2C), 151.4, 147.6, 137.9, 135.3, 124.5, 121.8, 121.2, 110.1, 104.1 (2C), 89.4, 74.3, 61.2, 61.0, $56.3(2 \mathrm{C}), 56.0$. 
HRMS (ESI): Calculated for $\mathrm{C}_{19} \mathrm{H}_{24} \mathrm{NaO}_{7}[\mathrm{M}+\mathrm{Na}]^{+}: 387.1414$, found: 387.1413.

$\mathbf{R}_{\mathbf{f}}($ hexanes/EtOAc 1:3) $=0.37$.

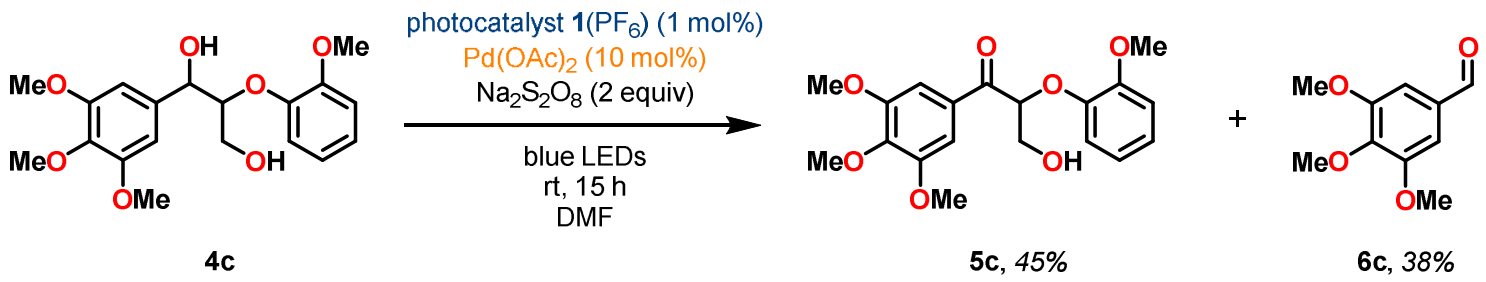

Oxidation of 2-(2-methoxyphenoxy)-1-(3,4,5-trimethoxyphenyl)propane-1,3-diol (4c). Performed according to "Representative Procedure for Oxidation of Lignin Model Systems". A round bottom flask was charged with $\left[\operatorname{Ir}\left\{\mathrm{dF}\left(\mathrm{CF}_{3}\right) \mathrm{ppy}\right\}_{2}(\mathrm{dtbbpy})\right] \mathrm{PF}_{6}(3.0 \mu \mathrm{mol}, 3.3 \mathrm{mg}, 1 \mathrm{~mol} \%), \mathrm{Pd}(\mathrm{OAc})_{2}(0.030$ mmol, $6.7 \mathrm{mg}, 10 \mathrm{~mol} \%), 2$-(2-methoxyphenoxy)-1-(3,4,5-trimethoxyphenyl)propane-1,3-diol (4c, $0.30 \mathrm{mmol}, 109 \mathrm{mg}), \mathrm{Na}_{2} \mathrm{~S}_{2} \mathrm{O}_{8}(0.60 \mathrm{mmol}, 143 \mathrm{mg}, 2$ equiv) and $\mathrm{DMF}(4.5 \mathrm{~mL})$. The resulting solution was degassed by repeated freeze-pump-thaw cycles ( 3 cycles) and the flask was back-filled with nitrogen. The reaction was then irradiated with a $4.4 \mathrm{~W}$ blue LED strip in a circle around the reaction flask (approximately $5 \mathrm{~cm}$ from the flask) and stirred at room temperature for $15 \mathrm{~h}$. After completion of the reaction, $\mathrm{CH}_{2} \mathrm{Cl}_{2}$ and $\mathrm{H}_{2} \mathrm{O}$ were added and the layers were separated. The aqueous layer was extracted with $\mathrm{CH}_{2} \mathrm{Cl}_{2}(3 \mathrm{x})$ and the combined organic layers were washed with $5 \%$ aq. $\mathrm{LiCl}(3 \mathrm{x})$, brine (2x), dried over $\mathrm{Na}_{2} \mathrm{SO}_{4}$ and filtered before concentrating the solution in vacuo. The crude residue was purified by column chromatography (hexanes/EtOAc 2:1) to afford 3-hydroxy-2-(2methoxyphenoxy)-1-(3,4,5-trimethoxyphenyl)propan-1-one (5c, $49 \mathrm{mg}, \quad 45 \%)$ and 3,4,5trimethoxybenzaldehyde (6c, $22 \mathrm{mg}, 38 \%$ ) as white solids.

\section{3-Hydroxy-2-(2-methoxyphenoxy)-1-(3,4,5-trimethoxyphenyl)propan-1-one (5c) ${ }^{55,513}$}

${ }^{1} \mathrm{H}$ NMR $\left(500 \mathrm{MHz}, \mathrm{CDCl}_{3}\right): \delta 7.36(\mathrm{~s}, 2 \mathrm{H}), 7.01(\mathrm{ddd}, J=8.2,7.5,1.6 \mathrm{~Hz}, 1 \mathrm{H}), 6.93-6.89(\mathrm{~m}, 2 \mathrm{H}), 6.84$ (ddd, $J=8.0,7.5,1.5 \mathrm{~Hz}, 1 \mathrm{H}), 5.35(\mathrm{dd}, J=5.8,4.8 \mathrm{~Hz}, 1 \mathrm{H}), 4.10-4.07(\mathrm{~m}, 2 \mathrm{H}), 3.92(\mathrm{~s}, 3 \mathrm{H}), 3.87(\mathrm{~s}$, $6 \mathrm{H}), 3.85(\mathrm{~s}, 3 \mathrm{H}), 2.02(\mathrm{br} \mathrm{s}, 1 \mathrm{H})$. 
${ }^{13} \mathrm{C}$ NMR (126 MHz, CDCl $)$ : $\delta$ 195.7, 153.2 (2C), 150.6, 146.9, 143.4, 130.1, 123.9, 121.4, 118.4, 112.4, $106.7(2 \mathrm{C}), 84.7,63.7,61.1,56.4(2 \mathrm{C}), 55.9$.

HRMS (ESI): Calculated for $\mathrm{C}_{19} \mathrm{H}_{22} \mathrm{NaO}_{7}[\mathrm{M}+\mathrm{Na}]^{+}: 385.1258$, found: 385.1260 .

$\mathbf{R}_{\mathrm{f}}$ (hexanes/EtOAc 1:2) $=0.41$.

\section{3,4,5-Trimethoxybenzaldehyde $(6 c)^{516}$}

${ }^{1} \mathrm{H}$ NMR $\left(500 \mathrm{MHz}, \mathrm{CDCl}_{3}\right)$ : $\delta 9.86(\mathrm{~s}, 1 \mathrm{H}), 7.13(\mathrm{~s}, 2 \mathrm{H}), 3.93(\mathrm{~s}, 3 \mathrm{H}), 3.93(\mathrm{~s}, 6 \mathrm{H})$.

${ }^{13} \mathrm{C}$ NMR (126 MHz, CDCl $): \delta$ 191.2, $153.8(2 \mathrm{C}), 143.7,131.8,106.8(2 \mathrm{C}), 61.1,56.4(2 \mathrm{C})$.

HRMS (ESI): Calculated for $\mathrm{C}_{10} \mathrm{H}_{13} \mathrm{O}_{4}[\mathrm{M}+\mathrm{H}]^{+}:$197.0808, found: 197.0806.

$\mathbf{R}_{\mathbf{f}}($ hexanes $/$ EtOAc 1:1) $=0.64$.
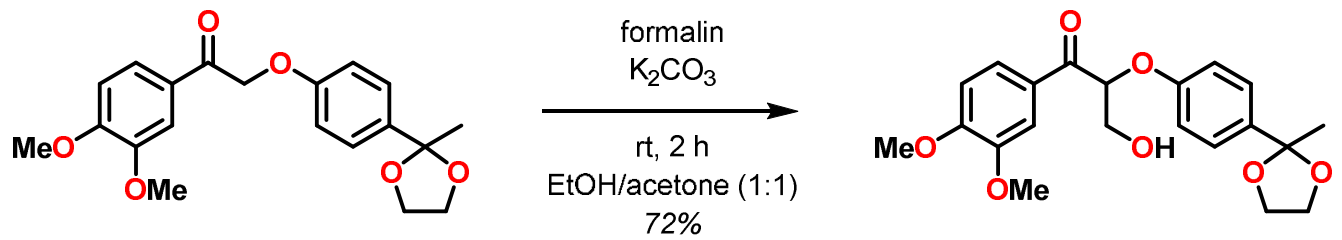

Synthesis of 1-(3,4-dimethoxyphenyl)-3-hydroxy-2-(4-(2-methyl-1,3-dioxolan-2-yl)phenoxy)propan-

1-one. To a stirred mixture of 1-(3,4-dimethoxyphenyl)-2-(4-(2-methyl-1,3-dioxolan-2yl)phenoxy)ethan-1-one $(1.00 \mathrm{~g}, 2.79 \mathrm{mmol})$ and $\mathrm{K}_{2} \mathrm{CO}_{3}(423 \mathrm{mg}, 3.07 \mathrm{mmol})$ in ethanol/acetone (1:1, $3 \mathrm{~mL}$ ) was added formalin (335 $\mu \mathrm{L}, 4.18 \mathrm{mmol})$. The reaction mixture was stirred for $2 \mathrm{~h}$ at room temperature and then filtered to remove the inorganics. The homogeneous filtrate was concentrated under reduced pressure and the resulting crude mixture was purified by column chromatography (hexanes/EtOAc/Et 3 N 50:50:0.1) to give the product as a colorless solid (790 mg, 72\%).

${ }^{1} \mathrm{H}$ NMR $\left(400 \mathrm{MHz}, \mathrm{CDCl}_{3}\right): \delta 7.76(\mathrm{dd}, J=8.5,2.0 \mathrm{~Hz}, 1 \mathrm{H}), 7.57(\mathrm{~d}, J=2.0 \mathrm{~Hz}, 1 \mathrm{H}), 7.36(\mathrm{~d}, J=8.7 \mathrm{~Hz}$, 2H), $6.91(\mathrm{~d}, J=8.5 \mathrm{~Hz}, 1 \mathrm{H}), 6.85(\mathrm{~d}, J=8.7 \mathrm{~Hz}, 2 \mathrm{H}), 5.53(\mathrm{dd}, J=6.3,4.1 \mathrm{~Hz}, 1 \mathrm{H}), 4.16(\mathrm{dd}, J=12.0,4.1$ 
$\mathrm{Hz}, 1 \mathrm{H}), 4.10(\mathrm{dd}, J=12.0,6.3 \mathrm{~Hz}, 1 \mathrm{H}), 4.03-3.98(\mathrm{~m}, 2 \mathrm{H}), 3.96(\mathrm{~s}, 3 \mathrm{H}), 3.90(\mathrm{~s}, 3 \mathrm{H}), 3.76-3.71(\mathrm{~m}, 2 \mathrm{H})$, $1.60(\mathrm{~s}, 3 \mathrm{H})$.

${ }^{13}$ C NMR (101 MHz, $\left.\mathrm{CDCl}_{3}\right): \delta 194.9,157.1,154.3,149.4,136.9,127.8,126.9(2 \mathrm{C}), 123.6,114.9$ (2C), $110.9,110.3,108.7,81.1,64.5(2 C), 63.7,56.2,56.0,27.7$.

HRMS (ESI): Calculated for $\mathrm{C}_{21} \mathrm{H}_{24} \mathrm{NaO}_{7}[\mathrm{M}+\mathrm{Na}]^{+}: 411.1414$, found: 411.1415 .

$\mathbf{R}_{\mathbf{f}}$ (hexanes/EtOAc 1:1) $=0.18$.
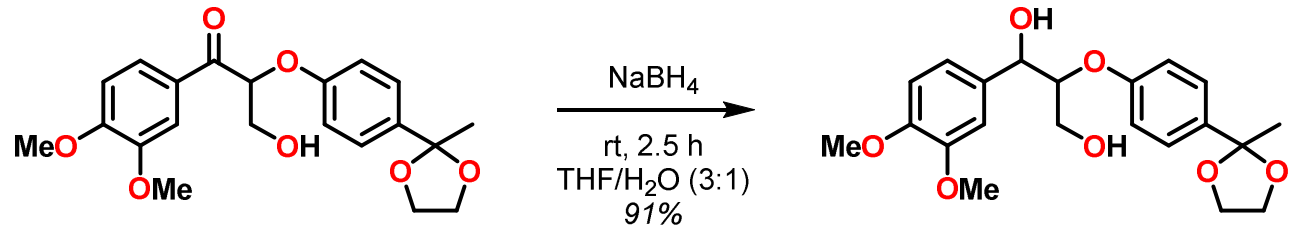

Synthesis of 1-(3,4-dimethoxyphenyl)-2-(4-(2-methyl-1,3-dioxolan-2-yl)phenoxy)propane-1,3-diol. To a solution of 1-(3,4-dimethoxyphenyl)-3-hydroxy-2-(4-(2-methyl-1,3-dioxolan-2yl)phenoxy)propan-1-one $\left(740 \mathrm{mg}, 2.0 \mathrm{mmol}\right.$ ) in $\mathrm{THF} / \mathrm{H}_{2} \mathrm{O}(3: 1,4.0 \mathrm{~mL})$ was added $\mathrm{NaBH}_{4}$ in three portions $(380 \mathrm{mg}, 10.0 \mathrm{mmol})$. The reaction was stirred at room temperature for $2.5 \mathrm{~h}$ and then diluted with $\mathrm{H}_{2} \mathrm{O}$ and $\mathrm{CH}_{2} \mathrm{Cl}_{2}$. The phases were separated and the aqueous phase was extracted with $\mathrm{CH}_{2} \mathrm{Cl}_{2}(3 \mathrm{x})$. The organic phases were collected, dried over $\mathrm{Na}_{2} \mathrm{SO}_{4}$, filtered and concentrated under reduced pressure. The product was obtained as a white solid $(710 \mathrm{mg}, 91 \%, 2: 1$ mixture of diastereomers) and was used in the next step without further purification.

\section{Major diastereomer}

${ }^{1} \mathrm{H}$ NMR (500 MHz, $\left.\mathrm{CDCl}_{3}\right): \delta 7.40(\mathrm{~d}, J=8.6 \mathrm{~Hz}, 2 \mathrm{H}), 7.01-6.94(\mathrm{~m}, 3 \mathrm{H}), 6.86(\mathrm{dd}, J=8.3,2.2 \mathrm{~Hz}, 2 \mathrm{H})$, $4.99(\mathrm{~d}, J=6.8 \mathrm{~Hz}, 1 \mathrm{H}), 4.42-4.38(\mathrm{~m}, 1 \mathrm{H}), 4.05-4.00(\mathrm{~m}, 2 \mathrm{H}), 3.88(\mathrm{~s}, 3 \mathrm{H}), 3.86(\mathrm{~s}, 3 \mathrm{H}), 3.82(\mathrm{dd}, J=$ $12.1,3.9 \mathrm{~Hz}, 1 \mathrm{H}), 3.79-3.75(\mathrm{~m}, 2 \mathrm{H}), 3.60(\mathrm{dd}, J=12.1,3.9 \mathrm{~Hz}, 1 \mathrm{H}), 1.63(\mathrm{~s}, 3 \mathrm{H})$.

${ }^{13} \mathrm{C}$ NMR (126 MHz, $\left.\mathrm{CDCl}_{3}\right): \delta 157.8,149.2,149.0,137.0,132.3,126.9(2 \mathrm{C}), 119.4,116.1(2 \mathrm{C}), 111.1$, $110.0,108.8,83.1,73.9,64.5(2 C), 61.3,56.0(2 C), 27.7$. 


\section{Minor diastereomer}

${ }^{1} \mathrm{H}$ NMR $\left(500 \mathrm{MHz}, \mathrm{CDCl}_{3}\right): \delta 7.35(\mathrm{~d}, J=8.6 \mathrm{~Hz}, 2 \mathrm{H}), 7.01-6.94(\mathrm{~m}, 4 \mathrm{H}), 6.86-6.83(\mathrm{~m}, 1 \mathrm{H}), 5.03(\mathrm{~d}, J=$ $5.6 \mathrm{~Hz}, 1 \mathrm{H}), 4.44-4.40(\mathrm{~m}, 1 \mathrm{H}), 4.05-4.00(\mathrm{~m}, 2 \mathrm{H}), 3.95(\mathrm{dd}, J=12.1,4.6 \mathrm{~Hz}, 1 \mathrm{H}), 3.88(\mathrm{~s}, 6 \mathrm{H}), 3.85-$ $3.80(\mathrm{~m}, 1 \mathrm{H}), 3.79-3.75(\mathrm{~m}, 2 \mathrm{H}), 1.62(\mathrm{~s}, 3 \mathrm{H})$.

${ }^{13} \mathrm{C}$ NMR (126 MHz, $\left.\mathrm{CDCl}_{3}\right): \delta$ 157.4, 149.1, 148.8, 136.8, 133.1, 126.8 (2C), 118.8, 116.1 (2C), 111.1, $109.6,108.8,81.9,74.1,64.5(2 \mathrm{C}), 61.6,56.0(2 \mathrm{C}), 27.7$.

HRMS (ESI): Calculated for $\mathrm{C}_{21} \mathrm{H}_{26} \mathrm{NaO}_{7}[\mathrm{M}+\mathrm{Na}]^{+}:$413.1571, found: 413.1574 .

$\mathbf{R}_{\mathrm{f}}$ (hexanes/EtOAc 1:1) $=0.10$.<smiles>COc1ccc(C(O)C(CO)Oc2ccc(C3(C)OCCO3)cc2)cc1OC</smiles>

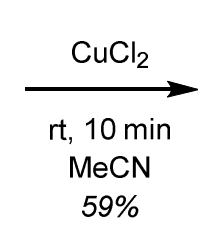

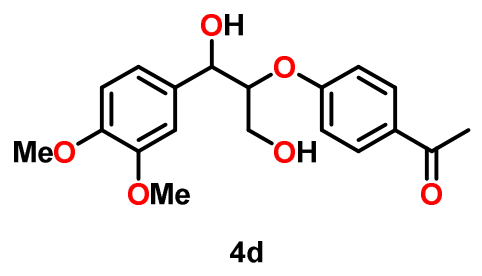

Synthesis of 1-(4-((1-(3,4-dimethoxyphenyl)-1,3-dihydroxypropan-2-yl)oxy)phenyl)ethan-1-one

(4d). To a stirred solution of 1-(3,4-dimethoxyphenyl)-2-(4-(2-methyl-1,3-dioxolan-2yl)phenoxy)propane-1,3-diol $(200 \mathrm{mg}, 0.51 \mathrm{mmol})$ in $\mathrm{MeCN}(5.0 \mathrm{~mL})$ was added $\mathrm{CuCl}_{2}(70 \mathrm{mg}, 0.53$ $\mathrm{mmol})$. The reaction was stirred at room temperature for $10 \mathrm{~min}$ after which the crude mixture was rapidly quenched with an aqueous saturated $\mathrm{NH}_{4} \mathrm{Cl}$ solution $(1 \mathrm{~mL})$ and stirred until the reaction turned blue (indicative of complexation). The resulting biphasic mixture was extracted with $\mathrm{CH}_{2} \mathrm{Cl}_{2}$ (3x) and washed with aqueous saturated $\mathrm{NH}_{4} \mathrm{Cl}$ solution. The organic layer was dried over $\mathrm{Na}_{2} \mathrm{SO}_{4}$, filtered, concentrated and purified by column chromatography (hexanes/EtOAc/Et ${ }_{3} \mathrm{~N}$ 50:50:0.1) to give the product as a white solid (104 mg, 59\%, 5:2 mixture of diastereomers). 


\section{Major diastereomer}

${ }^{1} \mathrm{H}$ NMR $\left(500 \mathrm{MHz}, \mathrm{CDCl}_{3}\right): \delta 7.92(\mathrm{~d}, J=8.8 \mathrm{~Hz}, 2 \mathrm{H}), 7.03(\mathrm{~d}, J=8.8 \mathrm{~Hz}, 2 \mathrm{H}), 7.00-6.94(\mathrm{~m}, 2 \mathrm{H}), 6.86$ (d, $J=8.0 \mathrm{~Hz}, 1 \mathrm{H}), 5.02(\mathrm{~d}, J=6.6 \mathrm{~Hz}, 1 \mathrm{H}), 4.57-4.52(\mathrm{~m}, 1 \mathrm{H}), 3.88(\mathrm{~s}, 3 \mathrm{H}), 3.87(\mathrm{~s}, 3 \mathrm{H}), 3.85(\mathrm{dd}, J=$ $12.1,4.0 \mathrm{~Hz}, 1 \mathrm{H}), 3.66(\mathrm{dd}, J=12.1,4.3 \mathrm{~Hz}, 1 \mathrm{H}), 2.55(\mathrm{~s}, 3 \mathrm{H})$.

${ }^{13} \mathrm{C}$ NMR (126 MHz, CDCl $)$ : $\delta$ 196.8, 162.2, 149.4, 149.3, 132.0, 131.3, 130.8 (2C), 119.4, 115.8 (2C), $111.2,109.9,82.8,74.0,61.6,56.1(2 \mathrm{C}), 26.5$.

\section{Minor diastereomer}

${ }^{1} \mathrm{H}$ NMR (500 MHz, CDCl 3 ): $\delta 7.87(\mathrm{~d}, J=8.8 \mathrm{~Hz}, 2 \mathrm{H}), 7.00-6.94(\mathrm{~m}, 2 \mathrm{H}), 6.92(\mathrm{~d}, J=8.8 \mathrm{~Hz}, 2 \mathrm{H}), 6.83$ (d, $J=8.0 \mathrm{~Hz}, 1 \mathrm{H}), 5.03(\mathrm{~d}, J=6.0 \mathrm{~Hz}, 1 \mathrm{H}), 4.57-4.52(\mathrm{~m}, 1 \mathrm{H}), 3.97(\mathrm{t}, J=4.3 \mathrm{~Hz}, 2 \mathrm{H}), 3.86(\mathrm{~s}, 3 \mathrm{H}), 3.86$ $(\mathrm{s}, 3 \mathrm{H}), 2.53(\mathrm{~s}, 3 \mathrm{H})$.

${ }^{13} \mathrm{C}$ NMR (126 MHz, CDCl $): \delta$ 196.8, 161.8, 149.2, 149.0, 132.8, 131.1, 130.8 (2C), 118.9, 115.7 (2C), $111.2,109.6,81.6,74.3,61.9,56.1(2 \mathrm{C}), 26.5$.

HRMS (ESI): Calculated for $\mathrm{C}_{19} \mathrm{H}_{22} \mathrm{NaO}_{6}[\mathrm{M}+\mathrm{Na}]^{+}: 369.1309$, found: 369.1308 .

$\mathbf{R}_{\mathbf{f}}$ (hexanes $/$ EtOAc 1:1) $=0.15$.

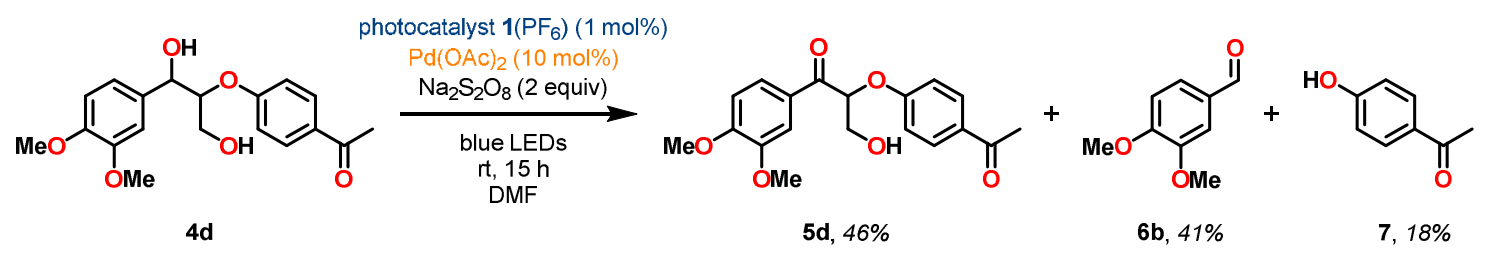

Oxidation of 1-(4-((1-(3,4-dimethoxyphenyl)-1,3-dihydroxypropan-2-yl)oxy)phenyl)ethan-1-one

(4d). Performed according to "Representative Procedure for Oxidation of Lignin Model Systems". A round bottom flask was charged with $\left[\operatorname{Ir}\left\{\mathrm{dF}\left(\mathrm{CF}_{3}\right) \mathrm{ppy}\right\}_{2}(\mathrm{dtbbpy})\right] \mathrm{PF}_{6}(3.0 \mu \mathrm{mol}, 3.3 \mathrm{mg}, 1 \mathrm{~mol} \%)$, $\mathrm{Pd}(\mathrm{OAc})_{2}$ (0.030 mmol, $\left.6.7 \mathrm{mg}, 10 \mathrm{~mol} \%\right)$, 1-(4-((1-(3,4-dimethoxyphenyl)-1,3-dihydroxypropan-2yl)oxy)phenyl)ethan-1-one (4d, $0.30 \mathrm{mmol}, 104 \mathrm{mg}), \mathrm{Na}_{2} \mathrm{~S}_{2} \mathrm{O}_{8}(0.60 \mathrm{mmol}, 143 \mathrm{mg}, 2$ equiv) and DMF 
$(4.5 \mathrm{~mL})$. The resulting solution was degassed by repeated freeze-pump-thaw cycles (3 cycles) and the flask was back-filled with nitrogen. The reaction was then irradiated with a $4.4 \mathrm{~W}$ blue LED strip in a circle around the reaction flask (approximately $5 \mathrm{~cm}$ from the flask) and stirred at room temperature for $15 \mathrm{~h}$. After completion of the reaction, $\mathrm{CH}_{2} \mathrm{Cl}_{2}$ and $\mathrm{H}_{2} \mathrm{O}$ were added and the layers were separated. The aqueous layer was extracted with $\mathrm{CH}_{2} \mathrm{Cl}_{2}(3 \mathrm{x})$ and the combined organic layers were washed with $5 \%$ aq. $\mathrm{LiCl}(3 \mathrm{x})$, brine $(2 \mathrm{x})$, dried over $\mathrm{Na}_{2} \mathrm{SO}_{4}$ and filtered before concentrating the solution in vacuo. The crude residue was purified by column chromatography (hexanes/EtOAc 6:1 to 1:1) to afford 2-(4-acetylphenoxy)-1-(3,4-dimethoxyphenyl)-3-hydroxypropan-1-one (5d, $47 \mathrm{mg}$, 46\%), 3,4-dimethoxybenzaldehyde (6b, $20.4 \mathrm{mg}, 41 \%)$ and 1-(4-hydroxyphenyl)ethan-1-one (7, 7.4 mg, $18 \%)$ as white solids.

\section{2-(4-Acetylphenoxy)-1-(3,4-dimethoxyphenyl)-3-hydroxypropan-1-one (5d)}

${ }^{1} \mathrm{H}$ NMR $\left(500 \mathrm{MHz}, \mathrm{CDCl}_{3}\right): \delta 7.88(\mathrm{~d}, J=8.8 \mathrm{~Hz}, 2 \mathrm{H}), 7.74(\mathrm{dd}, J=8.5,1.7 \mathrm{~Hz}, 1 \mathrm{H}), 7.55(\mathrm{~d}, J=1.7 \mathrm{~Hz}$, $1 \mathrm{H}), 6.91(\mathrm{~d}, J=8.8 \mathrm{~Hz}, 2 \mathrm{H}), 6.90(\mathrm{~d}, J=8.5 \mathrm{~Hz}, 1 \mathrm{H}), 5.63(\mathrm{dd}, J=6.3,3.7 \mathrm{~Hz}, 1 \mathrm{H}), 4.20(\mathrm{dd}, J=12.1,3.7$ $\mathrm{Hz}, 1 \mathrm{H}), 4.14(\mathrm{dd}, J=12.1,6.3 \mathrm{~Hz}, 1 \mathrm{H}), 3.96(\mathrm{~s}, 3 \mathrm{H}), 3.90(\mathrm{~s}, 3 \mathrm{H}), 2.51(\mathrm{~s}, 3 \mathrm{H}), 2.38(\mathrm{br} \mathrm{s}, 1 \mathrm{H})$.

${ }^{13} \mathrm{C}$ NMR (126 MHz, CDCl 3$): \delta$ 196.8, 194.0, 161.2, 154.5, 149.6, 131.4, 130.8 (2C), 127.6, 123.6, 114.9

(2C), 110.9, 110.4, 81.1, 63.7, 56.3, 56.1, 26.5.

HRMS (ESI): Calculated for $\mathrm{C}_{19} \mathrm{H}_{21} \mathrm{O}_{6}[\mathrm{M}+\mathrm{H}]^{+}: 345.1333$, found: 345.1330 .

$\mathbf{R}_{\mathbf{f}}($ hexanes/EtOAc 1:3) $=0.25$.

\section{1-(4-Hydroxyphenyl)ethan-1-one (7)}

${ }^{1}{ }^{\mathrm{H}} \mathrm{NMR}\left(500 \mathrm{MHz}, \mathrm{CDCl}_{3}\right): \delta 7.91(\mathrm{~d}, J=8.7 \mathrm{~Hz}, 2 \mathrm{H}), 6.90(\mathrm{~d}, J=8.7 \mathrm{~Hz}, 2 \mathrm{H}), 5.87(\mathrm{br} \mathrm{s}, 1 \mathrm{H}), 2.57(\mathrm{~s}$, $3 \mathrm{H})$.

${ }^{13}$ C NMR (126 MHz, CDCl 3$): \delta 197.4,160.4,131.2$ (2C), 130.5, 115.5 (2C), 26.5.

HRMS (ESI): Calculated for $\mathrm{C}_{8} \mathrm{H}_{9} \mathrm{O}_{2}[\mathrm{M}+\mathrm{H}]^{+}: 137.0597$, found: 137.0596 .

$\mathbf{R}_{\mathrm{f}}($ hexanes/EtOAc 2:1) $=0.26$. 

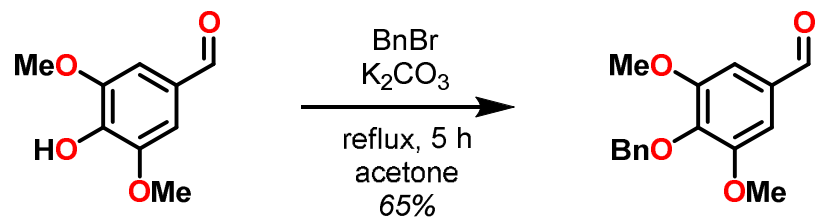

Synthesis of 4-(benzyloxy)-3,5-dimethoxybenzaldehyde. A flame-dried round bottom flask was charged with 4-hydroxy-3,5-dimethoxybenzaldehyde (3.64 g, $20.0 \mathrm{mmol})$, benzyl bromide $(3.59 \mathrm{~g}$, $21.0 \mathrm{mmol}), \mathrm{K}_{2} \mathrm{CO}_{3}(5.53 \mathrm{~g}, 40.0 \mathrm{mmol})$ and acetone $(50 \mathrm{~mL})$. The resulting mixture was refluxed for 5 $\mathrm{h}$ and then cooled down to room temperature. The mixture was filtered, washed with acetone and evaporated to give a light yellow residue, which was purified by column chromatography (hexanes/EtOAc 4:1) to afford the product as an off-white solid (3.56 g, 65\%). Spectral data are consistent with those reported in the literature. ${ }^{517}$

${ }^{1} \mathrm{H}$ NMR $\left(500 \mathrm{MHz}, \mathrm{CDCl}_{3}\right): \delta 9.86(\mathrm{~s}, 1 \mathrm{H}), 7.47(\mathrm{~d}, J=7.2 \mathrm{~Hz}, 2 \mathrm{H}), 7.34(\mathrm{t}, J=7.2 \mathrm{~Hz}, 2 \mathrm{H}), 7.30(\mathrm{~d}, J=$ $7.2 \mathrm{~Hz}, 1 \mathrm{H}), 7.11(\mathrm{~s}, 2 \mathrm{H}), 5.13(\mathrm{~s}, 2 \mathrm{H}), 3.90(\mathrm{~s}, 6 \mathrm{H})$.

${ }^{13}$ C NMR (126 MHz, CDCl $)$ ): $\delta$ 191.2, 154.1 (2C), 142.5, 137.3, 132.0, 128.5 (2C), 128.3 (2C), 128.2, $106.8(2 \mathrm{C}), 75.2,56.4(2 \mathrm{C})$.

HRMS (ESI): Calculated for $\mathrm{C}_{16} \mathrm{H}_{17} \mathrm{O}_{4}[\mathrm{M}+\mathrm{H}]^{+}: 273.1121$, found: 273.1119.

$\mathbf{R}_{\mathbf{f}}($ hexanes/EtOAc 2:1) $=0.54$. 

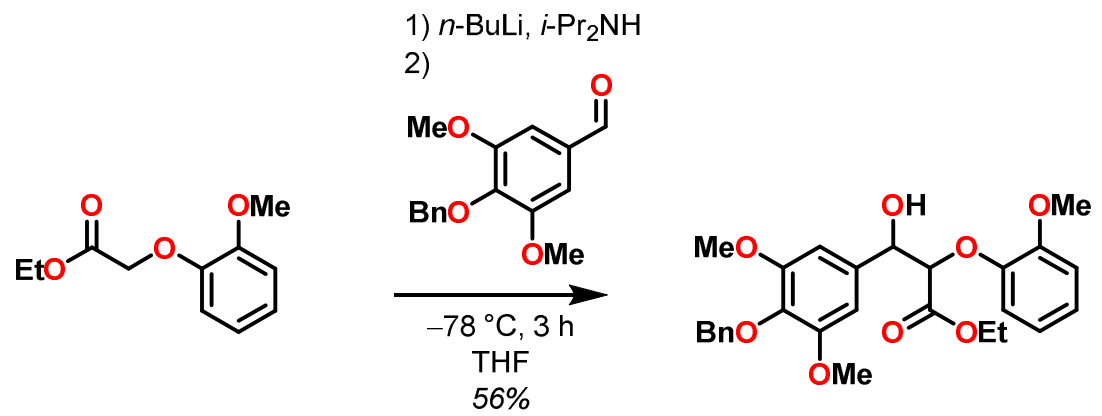

Synthesis of ethyl 3-(4-(benzyloxy)-3,5-dimethoxyphenyl)-3-hydroxy-2-(2-methoxyphenoxy)propanoate. $n$-BuLi (2.05 mL, $3.27 \mathrm{mmol}, 1.6 \mathrm{M}$ in hexanes) was added to a flame-dried round bottom flask containing a solution of diisopropylamine $(0.46 \mathrm{~mL}, 3.27 \mathrm{mmol})$ in THF $(10 \mathrm{~mL})$ at -78 ${ }^{\circ} \mathrm{C}$. The resulting solution was stirred at this temperature for $30 \mathrm{~min}$. To this mixture was added a THF solution $(5.00 \mathrm{~mL})$ of ethyl 2-(2-methoxyphenoxy)acetate $(0.63 \mathrm{~g}, 2.97 \mathrm{mmol})$ and the resulting solution was stirred at this temperature for $1 \mathrm{~h}$. To the resulting solution was added a THF solution (5.00 mL) of 4-(benzyloxy)-3,5-dimethoxybenzaldehyde $(0.81 \mathrm{~g}, 2.97 \mathrm{mmol})$. The resulting mixture was stirred for $3 \mathrm{~h}$ while maintaining the temperature at $-78{ }^{\circ} \mathrm{C}$ after which the mixture was diluted with $\mathrm{H}_{2} \mathrm{O}$ and extracted with EtOAc. The combined organic extracts were dried over $\mathrm{Na}_{2} \mathrm{SO}_{4}$, filtered and evaporated in vacuo to give a yellow oily residue. The oil was subjected to column chromatography (hexanes/EtOAc 3:1 to 1:1) to yield the product as a single diastereomer (erythro) as a white solid $(0.80 \mathrm{~g}, 56 \%)$. Spectral data are consistent with those reported in the literature. ${ }^{\mathrm{S} 18,519,520}$

${ }^{1} \mathrm{H}$ NMR $\left(500 \mathrm{MHz}, \mathrm{CDCl}_{3}\right): \delta 7.48(\mathrm{~d}, J=7.4 \mathrm{~Hz}, 2 \mathrm{H}), 7.35-7.27(\mathrm{~m}, 3 \mathrm{H}), 7.04-7.00(\mathrm{~m}, 1 \mathrm{H}), 6.92-6.82$ (m, 3H), $6.71(\mathrm{~s}, 2 \mathrm{H}), 5.13(\mathrm{~d}, J=5.2 \mathrm{~Hz}, 1 \mathrm{H}), 4.99(\mathrm{~s}, 2 \mathrm{H}), 4.72(\mathrm{~d}, J=5.2 \mathrm{~Hz}, 1 \mathrm{H}), 4.14(\mathrm{q}, J=7.2 \mathrm{~Hz}$, $2 \mathrm{H}), 3.85(\mathrm{~s}, 3 \mathrm{H}), 3.82(\mathrm{~s}, 6 \mathrm{H}), 1.14(\mathrm{t}, J=7.2 \mathrm{~Hz}, 3 \mathrm{H})$.

${ }^{13} \mathrm{C}$ NMR (126 MHz, CDCl $)$ ): $\delta$ 169.5, 153.4 (2C), 150.6, 147.3, 138.0, 136.8, 134.9, 128.6 (2C), 128.3 (2C), 127.9, 124.0, 121.2, 118.7, 112.4, 104.2 (2C), 83.7, 75.1, 74.2, 61.4, 56.2 (2C), 56.0, 14.2.

HRMS (ESI): Calculated for $\mathrm{C}_{27} \mathrm{H}_{30} \mathrm{NaO}_{8}[\mathrm{M}+\mathrm{Na}]^{+}: 505.1833$, found: 505.1830 .

$\mathbf{R}_{\mathrm{f}}($ hexanes $/$ EtOAc 1:1) $=0.50$. 

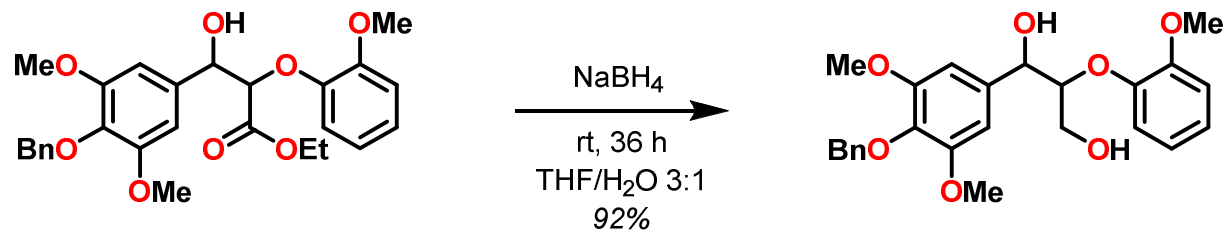

Synthesis of 1-(4-(benzyloxy)-3,5-dimethoxyphenyl)-2-(2-methoxyphenoxy)propane-1,3-diol. A round bottom flask was charged with ethyl 3-(4-(benzyloxy)-3,5-dimethoxyphenyl)-3-hydroxy-2-(2methoxyphenoxy)propanoate (300 mg, $0.622 \mathrm{mmol}), \mathrm{NaBH}_{4}(141 \mathrm{mg}, 3.73 \mathrm{mmol})$, and THF/ $\mathrm{H}_{2} \mathrm{O}(3: 1$, $4 \mathrm{~mL}$ ). The resulting mixture was stirred at room temperature for $36 \mathrm{~h}$. The reaction was diluted with $\mathrm{H}_{2} \mathrm{O}$ and $\mathrm{CH}_{2} \mathrm{Cl}_{2}$. The phases were separated and the aqueous phase was additionally extracted with $\mathrm{CH}_{2} \mathrm{Cl}_{2}(3 \mathrm{x})$. The combined organic extracts were washed with brine, dried over $\mathrm{Na}_{2} \mathrm{SO}_{4}$, filtered and evaporated under reduced pressure to give the product as a single diastereomer (erythro) as a viscous colorless oil (252 mg, 92\%). Spectral data are consistent with those reported in the literature..$^{57, \$ 20}$

${ }^{1} \mathrm{H}$ NMR $\left(500 \mathrm{MHz}, \mathrm{CDCl}_{3}\right): \delta 7.47(\mathrm{~d}, J=7.5 \mathrm{~Hz}, 2 \mathrm{H}), 7.35-7.27(\mathrm{~m}, 3 \mathrm{H}), 7.08$ (ddd, $J=8.2,7.9,1.7 \mathrm{~Hz}$, $1 \mathrm{H}), 6.98(\mathrm{dd}, J=7.9,1.7 \mathrm{~Hz}, 1 \mathrm{H}), 6.95(\mathrm{dd}, J=8.2,1.3 \mathrm{~Hz}, 1 \mathrm{H}), 6.92(\mathrm{td}, J=7.9,1.3 \mathrm{~Hz}, 1 \mathrm{H}), 6.59(\mathrm{~s}$, 2H), $4.99(\mathrm{~s}, 2 \mathrm{H}), 4.96(\mathrm{~d}, J=4.7 \mathrm{~Hz}, 1 \mathrm{H}), 4.15$ (ddd, J = 6.2, 4.7, $3.4 \mathrm{~Hz}, 1 \mathrm{H}$ ), 3.92 (dd, $J=12.2,6.2 \mathrm{~Hz}$, $1 \mathrm{H}), 3.90(\mathrm{~s}, 3 \mathrm{H}), 3.80(\mathrm{~s}, 6 \mathrm{H}), 3.65(\mathrm{dd}, J=12.2,3.4 \mathrm{~Hz}, 1 \mathrm{H}), 3.55(\mathrm{br} \mathrm{s}, 1 \mathrm{H}), 2.70(\mathrm{br} \mathrm{s}, 1 \mathrm{H})$.

${ }^{13} \mathrm{C}$ NMR (126 MHz, CDCl $): \delta 153.9$ (2C), 152.0, 147.3, 138.2, 137.0, 135.8, $128.6(2 \mathrm{C}), 128.3$ (2C), $127.9,124.4,121.9,121.2,112.7,103.9(2 \mathrm{C}), 87.5,75.2,73.3,61.1,56.5(2 \mathrm{C}), 56.2$.

HRMS (ESI): Calculated for $\mathrm{C}_{25} \mathrm{H}_{28} \mathrm{NaO}_{7}[\mathrm{M}+\mathrm{Na}]^{+}: 463.1727$, found: 463.1725 .

$\mathbf{R}_{\mathbf{f}}($ hexanes $/$ EtOAc 1:3) $=0.55$. 

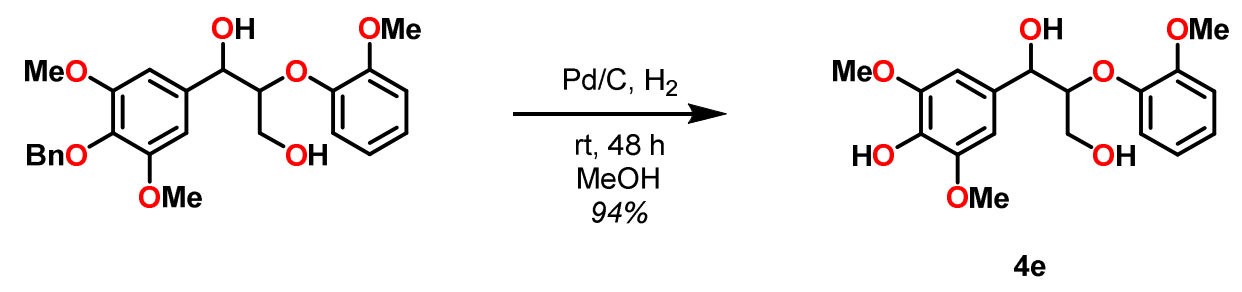

Synthesis of 1-(4-hydroxy-3,5-dimethoxyphenyl)-2-(2-methoxyphenoxy)propane-1,3-diol (4e). Pd/C

(10 wt\%, $18.0 \mathrm{mg}, 0.0169 \mathrm{mmol} \mathrm{Pd}$ ) was added to a MeOH solution ( $3 \mathrm{~mL}$ ) of 1-(4-(benzyloxy)-3,5dimethoxyphenyl)-2-(2-methoxyphenoxy)propane-1,3-diol (diastereomeric mixture, erythro:threo $6: 1,180 \mathrm{mg}, 0.409 \mathrm{mmol})$. The resulting mixture was subjected to one cycle of vacuum $/ \mathrm{H}_{2}$ to exclude air and then hydrogenated with a hydrogen balloon at room temperature for $48 \mathrm{~h}$. The reaction mixture was then filtered through Celite, washed with $\mathrm{MeOH}$ and concentrated under reduced pressure. Purification by column chromatography (hexanes/EtOAc 1:1) afforded the title compound as a mixture of diastereomers (erythro:threo 6:1) as a colorless oil, which solidified upon drying under reduced pressure (135 $\mathrm{mg}, 94 \%)$.

\section{Major diastereomer (erythro) $)^{55,520}$}

${ }^{1} \mathrm{H}$ NMR $\left(500 \mathrm{MHz}, \mathrm{CDCl}_{3}\right): \delta 7.09-7.03(\mathrm{~m}, 1 \mathrm{H}), 6.96-6.89(\mathrm{~m}, 3 \mathrm{H}), 6.61(\mathrm{~s}, 2 \mathrm{H}), 5.58(\mathrm{br} \mathrm{s}, 1 \mathrm{H}), 4.94$ (d, $J=4.7 \mathrm{~Hz}, 1 \mathrm{H}$ ), 4.14 (ddd, $J=6.0,4.7,3.2 \mathrm{~Hz}, 1 \mathrm{H}$ ), 3.91 (dd, $J=12.2,6.0 \mathrm{~Hz}, 1 \mathrm{H}$ ), $3.87(\mathrm{~s}, 3 \mathrm{H}), 3.85$ (s, 6H), 3.66 (dd, J=12.2, $3.2 \mathrm{~Hz}, 1 \mathrm{H}), 2.80$ (br s, 1H).

${ }^{13} \mathrm{C}$ NMR (126 MHz, $\left.\mathrm{CDCl}_{3}\right): \delta$ 151.6, 147.2 (2C), 147.0, 134.2, 131.2, 124.3, 121.7, 120.9, 112.3, 102.9 (2C), 87.4, 73.0, 60.9, $56.5(2 \mathrm{C}), 56.0$.

\section{Minor diastereomer (threo) $)^{55,520}$}

${ }^{1} \mathbf{H}$ NMR $\left(500 \mathrm{MHz}, \mathrm{CDCl}_{3}\right): \delta 7.12(\mathrm{dd}, J=7.8,1.1 \mathrm{~Hz}, 1 \mathrm{H}), 7.09-7.03(\mathrm{~m}, 1 \mathrm{H}), 6.96-6.89(\mathrm{~m}, 2 \mathrm{H}), 6.68$ (s, 2H), 5.61 (br s, 1H), $4.96(\mathrm{~d}, J=7.2 \mathrm{~Hz}, 1 \mathrm{H}), 4.01$ (ddd, J = 7.2, 3.6, 3.1 Hz, 1H), $3.90(\mathrm{~s}, 3 \mathrm{H}), 3.87(\mathrm{~s}$, $6 \mathrm{H}), 3.66-3.62(\mathrm{~m}, 1 \mathrm{H}), 3.48(\mathrm{dd}, J=12.5,3.6 \mathrm{~Hz}, 1 \mathrm{H}), 2.80$ (br s, $1 \mathrm{H}$ ). 
${ }^{13} \mathrm{C}$ NMR (126 MHz, CDCl $)$ : $\delta$ 151.4, 147.6, 147.2 (2C), 134.7, 130.8, 124.4, 121.8, 121.1, 112.3, 103.9

(2C), 89.5, 74.3, 61.1, 56.5 (2C), 56.0.

HRMS (ESI): Calculated for $\mathrm{C}_{18} \mathrm{H}_{22} \mathrm{NaO}_{7}[\mathrm{M}+\mathrm{Na}]^{+}: 373.1258$, found: 373.1255 .

$\mathbf{R}_{\mathbf{f}}($ hexanes/EtOAc 1:4) $=0.27$.

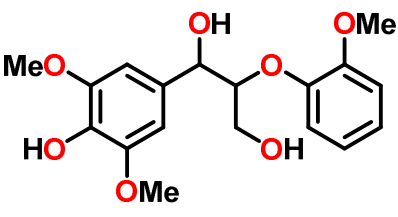

$4 e$ photocatalyst $\mathbf{1}\left(\mathrm{PF}_{6}\right)(1 \mathrm{~mol} \%)$

$\mathrm{Pd}(\mathrm{OAc})_{2}(10 \mathrm{~mol} \%)$

$\mathrm{Na}_{2} \mathrm{~S}_{2} \mathrm{O}_{8}$ (2 equiv)

blue LEDs

$\mathrm{rt}, 15 \mathrm{~h}$

DMF

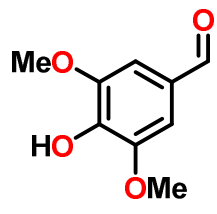

$6 \mathrm{~d}, 11 \%$

Oxidation of 1-(4-hydroxy-3,5-dimethoxyphenyl)-2-(2-methoxyphenoxy)propane-1,3-diol (4e).

Performed according to "Representative Procedure for Oxidation of Lignin Model Systems". A round bottom flask was charged with $\left[\operatorname{Ir}\left\{\mathrm{dF}\left(\mathrm{CF}_{3}\right) \text { ppy }\right\}_{2}(\mathrm{dtbbpy})\right] \mathrm{PF}_{6}(3.0 \mu \mathrm{mol}, 3.3 \mathrm{mg}, 1 \mathrm{~mol} \%), \mathrm{Pd}(\mathrm{OAc})_{2}$ (0.030 mmol, $6.7 \mathrm{mg}, 10 \mathrm{~mol} \%), 1$-(4-hydroxy-3,5-dimethoxyphenyl)-2-(2-methoxyphenoxy)propane1,3-diol (4e, $0.30 \mathrm{mmol}, 105 \mathrm{mg}), \mathrm{Na}_{2} \mathrm{~S}_{2} \mathrm{O}_{8}(0.60 \mathrm{mmol}, 143 \mathrm{mg}, 2$ equiv) and DMF (4.5 mL). The resulting solution was degassed by repeated freeze-pump-thaw cycles ( 3 cycles) and the flask was back-filled with nitrogen. The reaction was then irradiated with a $4.4 \mathrm{~W}$ blue LED strip in a circle around the reaction flask (approximately $5 \mathrm{~cm}$ from the flask) and stirred at room temperature for 15 h. After completion of the reaction, $\mathrm{CH}_{2} \mathrm{Cl}_{2}$ and $\mathrm{H}_{2} \mathrm{O}$ were added and the layers were separated. The aqueous layer was extracted with $\mathrm{CH}_{2} \mathrm{Cl}_{2}(3 \mathrm{x})$ and the combined organic layers were washed with $5 \%$ aq. $\mathrm{LiCl}(3 \mathrm{x})$, brine $(2 \mathrm{x})$, dried over $\mathrm{Na}_{2} \mathrm{SO}_{4}$ and filtered before concentrating the solution in vacuo. The crude residue was purified by column chromatography (hexanes/EtOAc 2:1) to afford 4-hydroxy3,5-dimethoxybenzaldehyde (6d) as a white solid (6.0 $\mathrm{mg}, 11 \%)$.

\section{4-Hydroxy-3,5-dimethoxybenzaldehyde $(6 \mathrm{~d})^{\mathrm{s21}}$}

${ }^{1} \mathrm{H}$ NMR (500 MHz, DMSO- $\left.d_{6}\right): \delta 9.78(\mathrm{~s}, 1 \mathrm{H}), 9.61(\mathrm{~s}, 1 \mathrm{H}), 7.21(\mathrm{~s}, 2 \mathrm{H}), 3.84(\mathrm{~s}, 6 \mathrm{H})$. 
${ }^{13}$ C NMR (126 MHz, DMSO- $\left.d_{6}\right): \delta$ 191.2, 148.1 (2C), 142.1, 127.1, 107.1 (2C), 56.1 (2C).

HRMS (ESI): Calculated for $\mathrm{C}_{9} \mathrm{H}_{10} \mathrm{NaO}_{4}[\mathrm{M}+\mathrm{Na}]^{+}:$: 205.0471, found: 205.0471.

$\mathbf{R}_{\mathrm{f}}($ hexanes $/$ EtOAc 1:1) $=0.39$.

\section{Emission Quenching Studies}

Emission intensities were recorded using a Fluoromax-2 Fluorimeter. All quenching data was recorded using a screw-top quartz cuvette with a stir bar at ambient temperature. Stock solutions of $\left[\operatorname{Ir}\left\{\mathrm{dF}\left(\mathrm{CF}_{3}\right) \mathrm{ppy}_{2}(\mathrm{dtbbpy})\right] \mathrm{PF}_{6}\left(\mathbf{1}\left(\mathrm{PF}_{6}\right), 1.34 \mathrm{mM}\right), \operatorname{Pd}(\mathrm{OAc})_{2}(13.0 \mathrm{mM}), \mathrm{Na}_{2} \mathrm{~S}_{2} \mathrm{O}_{8}(49.4 \mathrm{mM})\right.$ and substrate $\mathbf{2 b}(23.7 \mathrm{mM})$ in DMF were prepared. All solutions were degassed by repeated freezepump-thaw cycles ( 3 cycles) and the flask was back-filled with nitrogen.

In a typical procedure, the appropriate amount of quencher was added to $1.0 \mathrm{~mL}$ of the $\left[\operatorname{Ir}\left\{\mathrm{dF}\left(\mathrm{CF}_{3}\right) \mathrm{ppy}\right\}_{2}(\mathrm{dtbbpy})\right] \mathrm{PF}_{6}$ stock solution and the resulting solution was subsequently diluted to a total volume of $3.0 \mathrm{~mL}$. All solutions were excited at $427 \mathrm{~nm}$ and the emission was measured at 477 $\mathrm{nm}$ and is the average of three measurements.

The quenching was then plotted according to the Stern-Volmer relationship: ${ }^{522}$

$I_{0} / I=k_{\mathrm{q}} \cdot \tau_{0} \cdot[\mathrm{Q}]+1$

where $I_{0}=$ the emission intensity of the photocatalyst in the absence of a quencher, $I=$ the emission intensity of the photocatalyst in the presence of a quencher, $k_{\mathrm{q}}=$ the quenching rate constant, and $\tau_{0}=$ the lifetime of the emissive excited state of the photocatalyst in the absence of a quencher. The slope $k_{\mathrm{q}} \cdot \tau_{0}$ is also termed the Stern-Volmer constant $\left(K_{\mathrm{sv}}\right)$. 


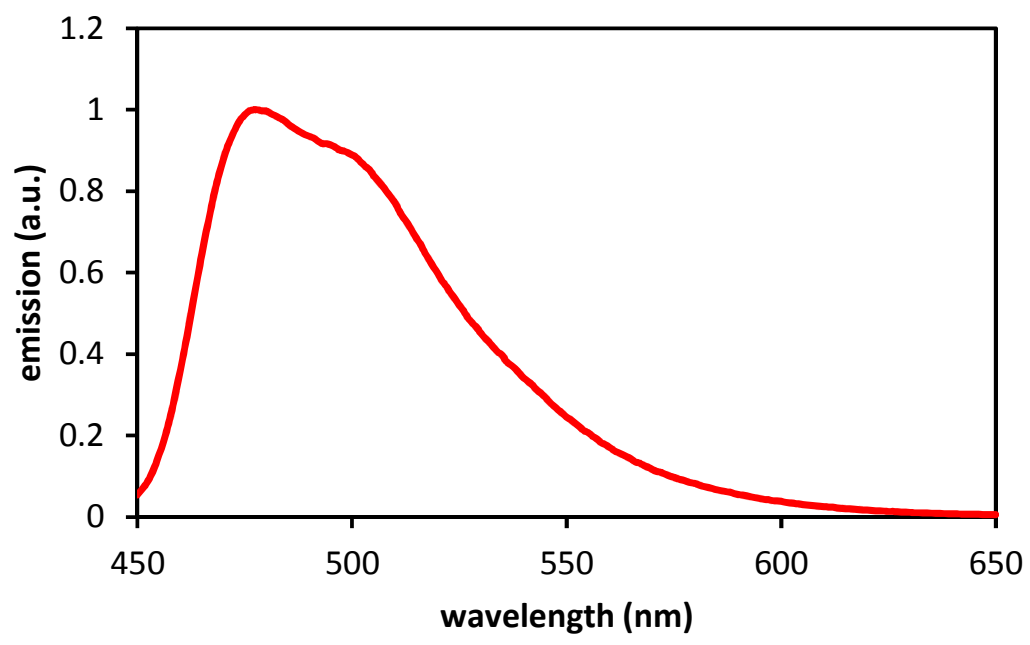

Figure S1. Emission spectra for $\left[\operatorname{Ir}\left\{\mathrm{dF}\left(\mathrm{CF}_{3}\right) \mathrm{ppy}\right\}_{2}(\mathrm{dtbbpy})\right] \mathrm{PF}_{6}\left(\mathbf{1}\left(\mathrm{PF}_{6}\right)\right)$ in DMF. Excitation wavelength $\left(\lambda_{\text {ex }}\right)$ is $427 \mathrm{~nm}$.

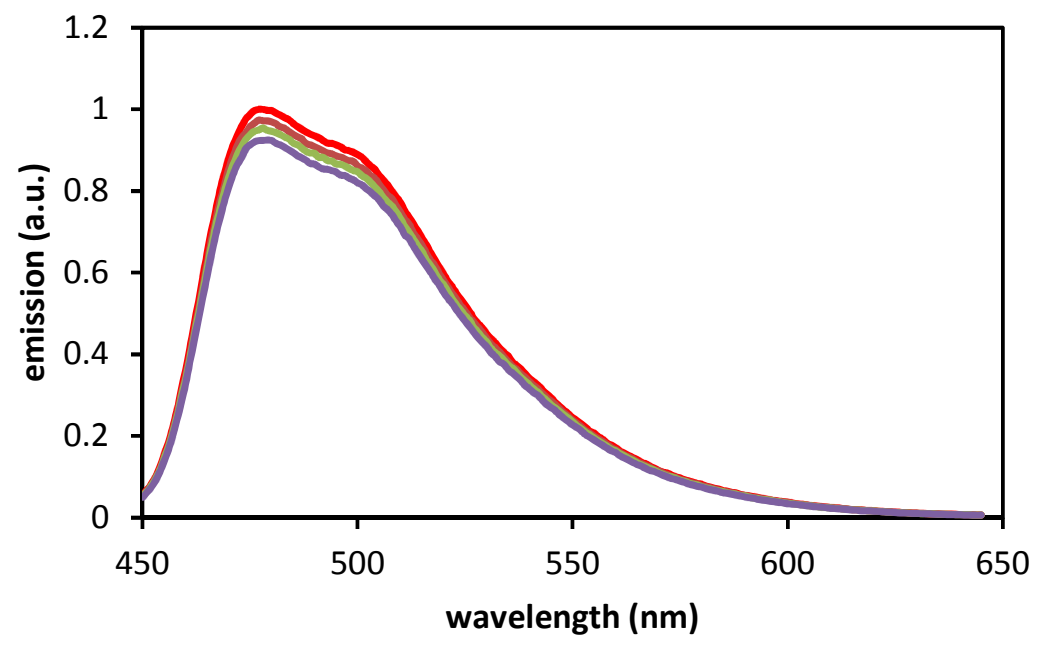

Figure S2. Emission spectra of $\left[\operatorname{Ir}\left\{\mathrm{dF}\left(\mathrm{CF}_{3}\right) \mathrm{ppy}\right\}_{2}(\mathrm{dtbbpy})\right] \mathrm{PF}_{6}\left(\mathbf{1}\left(\mathrm{PF}_{6}\right)\right)$ in $\mathrm{DMF}$ in the presence of substrate $\mathbf{2} \mathbf{b}$ as quencher. Excitation wavelength $\left(\lambda_{\mathrm{ex}}\right)$ is $427 \mathrm{~nm}$. $(=)$ Photocatalyst $\mathbf{1}\left(\mathrm{PF}_{6}\right) .(=) 0.91$ $\mathrm{mM}$ 2b. $(\Longrightarrow) 1.82 \mathrm{mM}$ 2b. $\Longrightarrow) 4.56 \mathrm{mM} 2$ b. 


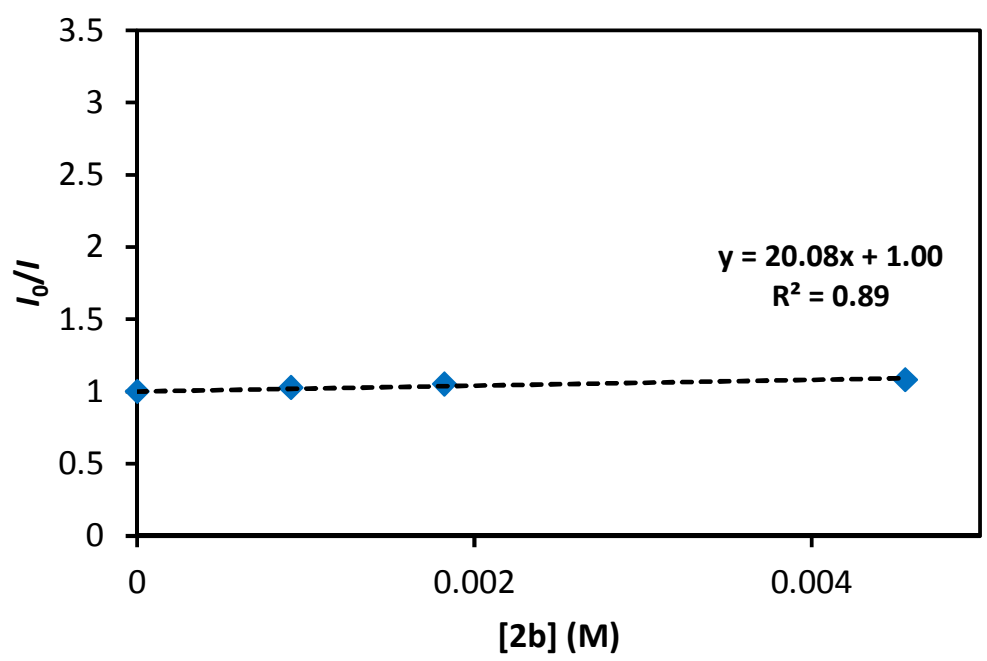

Figure S3. $\left[\operatorname{Ir}\left\{\mathrm{dF}\left(\mathrm{CF}_{3}\right) \mathrm{ppy}\right\}_{2}(\mathrm{dtbbpy})\right] \mathrm{PF}_{6}\left(\mathbf{1}\left(\mathrm{PF}_{6}\right)\right)$ emission quenching with substrate $\mathbf{2 b}$.

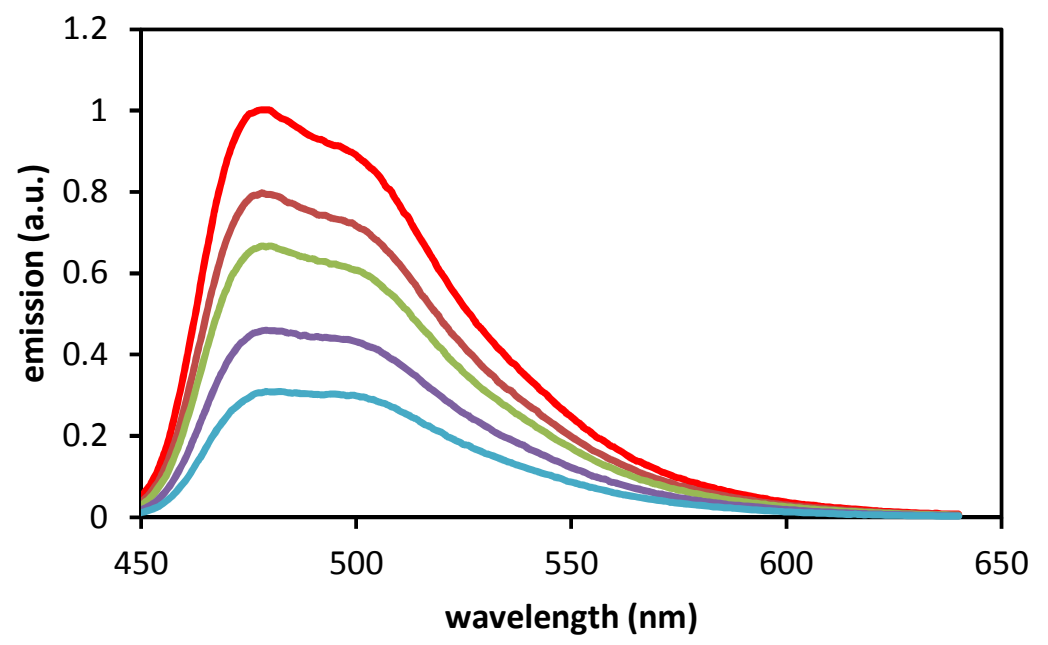

Figure S4. Emission spectra of $\left[\operatorname{Ir}\left\{\mathrm{dF}\left(\mathrm{CF}_{3}\right) \text { ppy }\right\}_{2}(\mathrm{dtbbpy})\right] \mathrm{PF}_{6}\left(\mathbf{1}\left(\mathrm{PF}_{6}\right)\right)$ in $\mathrm{DMF}$ in the presence of $\mathrm{Pd}(\mathrm{OAc})_{2}$ as quencher. Excitation wavelength $\left(\lambda_{\mathrm{ex}}\right)$ is $427 \mathrm{~nm} .(=)$ Photocatalyst $\mathbf{1}\left(\mathrm{PF}_{6}\right) .(=0.43 \mathrm{mM}$ $\mathrm{Pd}(\mathrm{OAc})_{2 .}\left(=0.86 \mathrm{mM} \mathrm{Pd}(\mathrm{OAc})_{2} .(=) 1.74 \mathrm{mM} \mathrm{Pd}(\mathrm{OAc})_{2} .(=) 2.60 \mathrm{mM} \mathrm{Pd}(\mathrm{OAc})_{2}\right.$ 


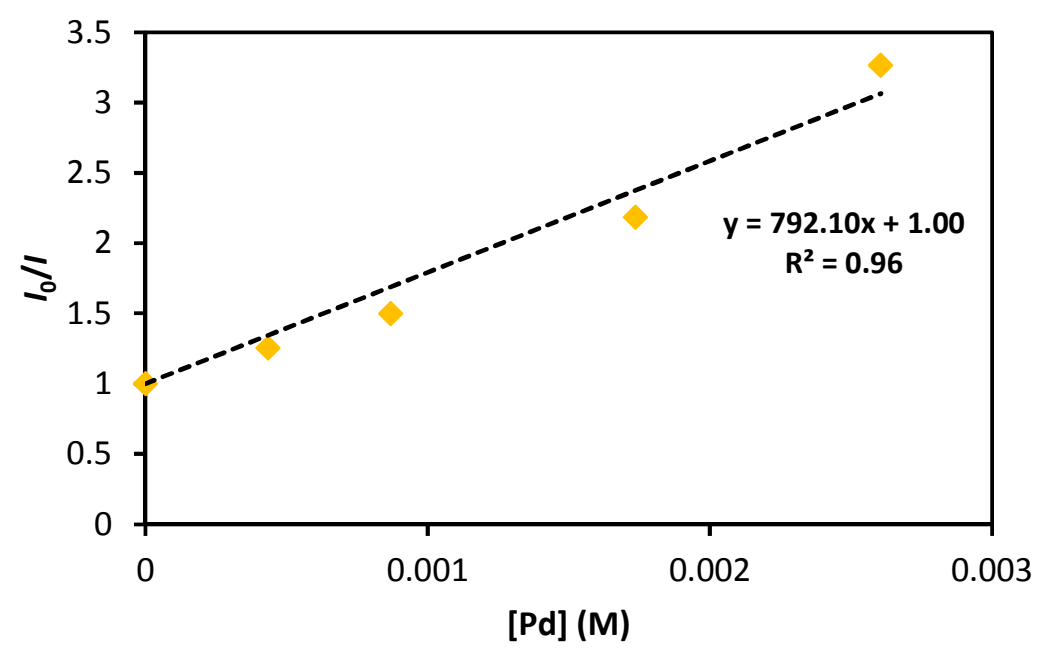

Figure S5. $\left[\operatorname{Ir}\left\{\mathrm{dF}\left(\mathrm{CF}_{3}\right) \mathrm{ppy}\right\}_{2}(\mathrm{dtbbpy})\right] \mathrm{PF}_{6}\left(\mathbf{1}\left(\mathrm{PF}_{6}\right)\right)$ emission quenching with $\mathrm{Pd}(\mathrm{OAc})_{2}$.

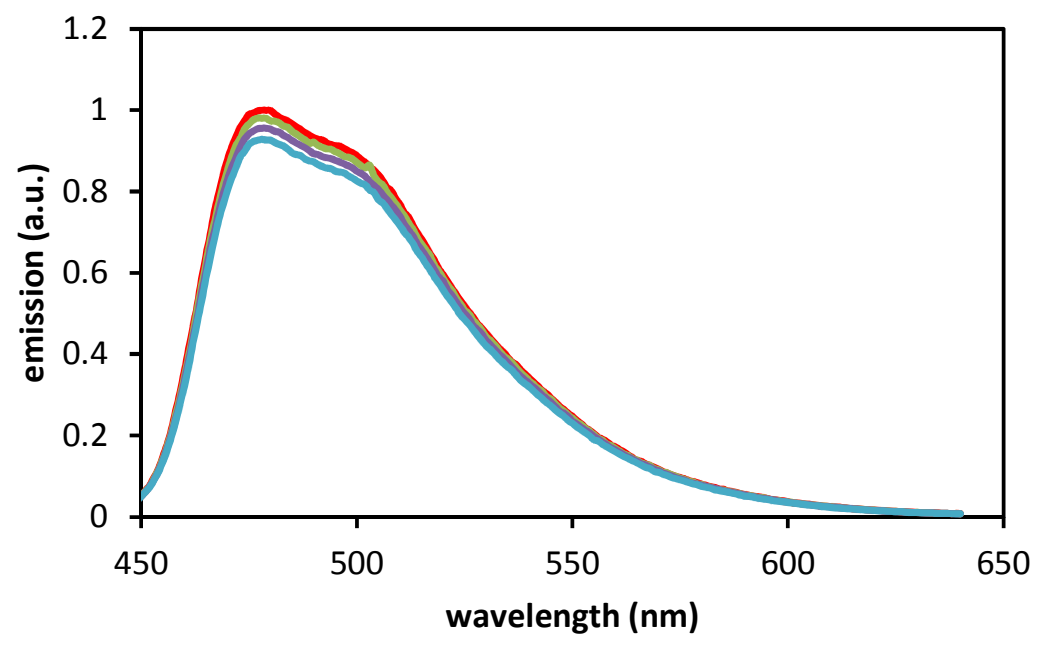

Figure S6. Emission spectra of $\left[\operatorname{Ir}\left\{\mathrm{dF}\left(\mathrm{CF}_{3}\right) \text { ppy }\right\}_{2}(\mathrm{dtbbpy})\right] \mathrm{PF}_{6}\left(\mathbf{1}\left(\mathrm{PF}_{6}\right)\right)$ in $\mathrm{DMF}$ in the presence of $\mathrm{Na}_{2} \mathrm{~S}_{2} \mathrm{O}_{8}$ as quencher. Excitation wavelength $\left(\lambda_{\text {ex }}\right)$ is $427 \mathrm{~nm}$. $(=)$ Photocatalyst $1\left(\mathrm{PF}_{6}\right) .(=) 3.3 \mathrm{mM} \mathrm{Na}_{2} \mathrm{~S}_{2} \mathrm{O}_{8} .(=$ $\Rightarrow 16.5 \mathrm{mM} \mathrm{Na}_{2} \mathrm{~S}_{2} \mathrm{O}_{8} .(=) 32.9 \mathrm{mM} \mathrm{Na}_{2} \mathrm{~S}_{2} \mathrm{O}_{8}$. 


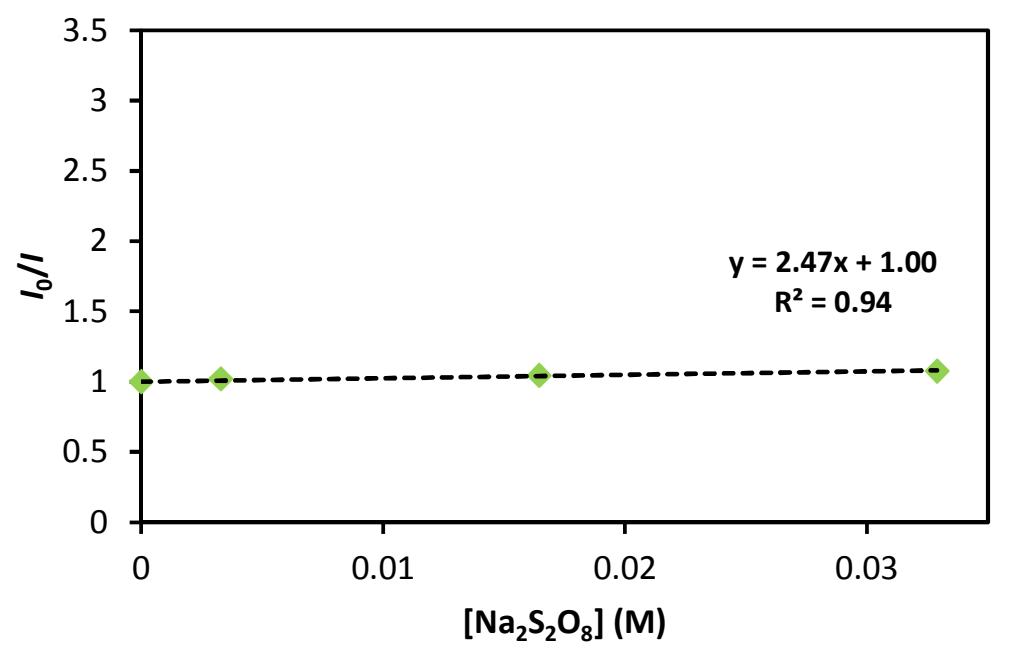

Figure S7. $\left[\operatorname{Ir}\left\{\mathrm{dF}\left(\mathrm{CF}_{3}\right) \text { ppy }\right\}_{2}(\mathrm{dtbbpy})\right] \mathrm{PF}_{6}\left(\mathbf{1}\left(\mathrm{PF}_{6}\right)\right)$ emission quenching with $\mathrm{Na}_{2} \mathrm{~S}_{2} \mathrm{O}_{8}$.

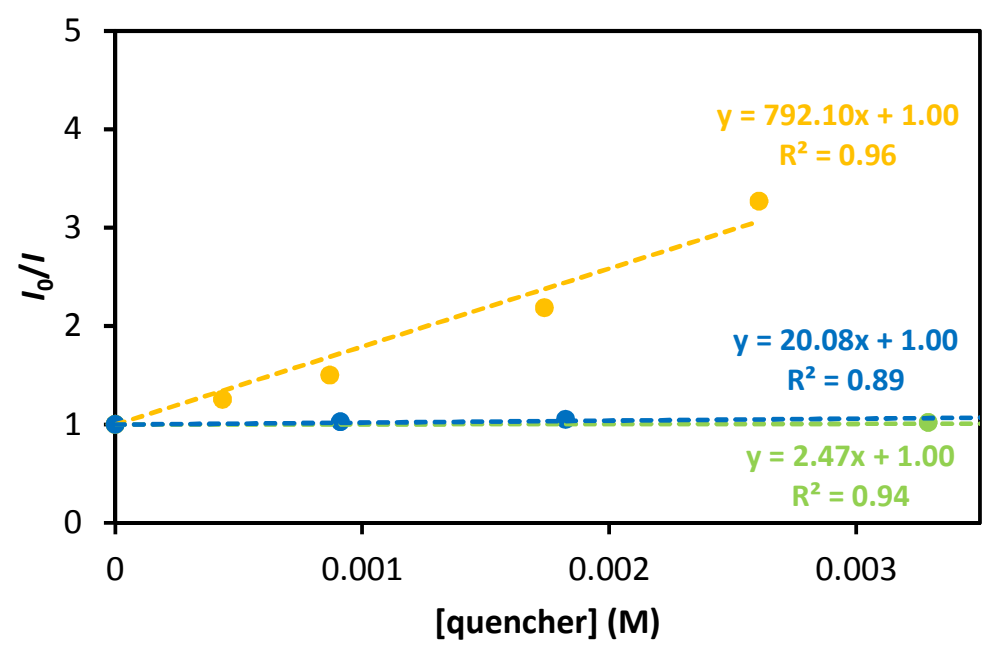

Figure S8. $\left[\operatorname{Ir}\left\{\mathrm{dF}\left(\mathrm{CF}_{3}\right) \mathrm{ppy}_{2}(\mathrm{dtbbpy})\right] \mathrm{PF}_{6}\left(\mathbf{1}\left(\mathrm{PF}_{6}\right)\right)\right.$ emission quenching with $\mathrm{Pd}(\mathrm{OAc})_{2}, \mathrm{Na}_{2} \mathrm{~S}_{2} \mathrm{O}_{8}$ and

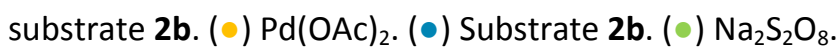

By using $\tau_{0}=2.3 \mu \mathrm{s},{ }^{\mathrm{S} 23}$ the quenching rate constants $\left(k_{\mathrm{q}}\right)$ can be calculated from the Stern-Volmer relationship, and are shown in Table S1. 
Table S1. Summary of the quenching data for the evaluated quenchers.

\begin{tabular}{ccc}
\hline Quencher & $\boldsymbol{k}_{\mathrm{q}} \cdot \boldsymbol{\tau}_{\mathbf{0}}\left(\boldsymbol{K}_{\mathrm{sv}} ; \mathbf{M}^{-\mathbf{1}}\right)$ & $\boldsymbol{k}_{\mathrm{q}}\left(\mathbf{M}^{-1} \mathbf{s}^{-1}\right)$ \\
\hline Substrate 2b & 20.08 & $8.73 \cdot 10^{6}$ \\
$\mathrm{Pd}(\mathrm{OAc})_{2}$ & 792.1 & $3.44 \cdot 10^{8}$ \\
$\mathrm{Na}_{2} \mathrm{~S}_{2} \mathrm{O}_{8}$ & 2.47 & $1.07 \cdot 10^{6}$ \\
\hline
\end{tabular}

\section{Representative Procedure for Filtration Test}

According to the general procedure, lignin model substrate $\mathbf{2 b}(0.30 \mathrm{mmol})$ was dissolved in DMF (4.5 $\mathrm{mL})$ in a round bottom flask. This flask was charged with $\left[\operatorname{Ir}\left\{\mathrm{dF}\left(\mathrm{CF}_{3}\right) \mathrm{ppy}\right\}_{2}(\mathrm{dtbbpy})\right] \mathrm{PF} \mathrm{F}_{6}(3.0 \mu \mathrm{mol}, 3.3$ mg, $1 \mathrm{~mol} \%), \mathrm{Pd}(\mathrm{OAc})_{2}(0.030 \mathrm{mmol}, 6.7 \mathrm{mg}, 10 \mathrm{~mol} \%)$, and $\mathrm{Na}_{2} \mathrm{~S}_{2} \mathrm{O}_{8}(0.60 \mathrm{mmol}, 143 \mathrm{mg}, 2$ equiv). The resulting solution was degassed by repeated freeze-pump-thaw cycles ( 3 cycles) and the flask was back-filled with nitrogen. The reaction was then irradiated with a $4.4 \mathrm{~W}$ blue LED strip in a circle around the reaction flask (approximately $5 \mathrm{~cm}$ from the flask) and stirred at room temperature until $\sim 30 \%$ conversion was obtained. The reaction mixture was then passed through a small plug of Celite to a new round bottom flask. This solution was then degassed by repeated freeze-pump-thaw cycles (3 cycles), back-filled with nitrogen and irradiated. The reaction was shown to result in full conversion of starting material to afford the desired oxidized product.

\section{Representative Procedure for Mercury Poisoning Test ${ }^{\mathrm{s24}}$}

According to the general procedure, lignin model substrate $\mathbf{2 b}(0.30 \mathrm{mmol})$ was dissolved in DMF (4.5 $\mathrm{mL})$ in a round bottom flask. This flask was charged with $\left[\operatorname{Ir}\left\{\mathrm{dF}\left(\mathrm{CF}_{3}\right) \text { ppy }\right\}_{2}(\mathrm{dtbbpy})\right] \mathrm{PF}_{6}(3.0 \mu \mathrm{mol}, 3.3$ mg, $1 \mathrm{~mol} \%), \mathrm{Pd}(\mathrm{OAc})_{2}(0.030 \mathrm{mmol}, 6.7 \mathrm{mg}, 10 \mathrm{~mol} \%)$, and $\mathrm{Na}_{2} \mathrm{~S}_{2} \mathrm{O}_{8}(0.60 \mathrm{mmol}, 143 \mathrm{mg}, 2$ equiv). The resulting solution was degassed by repeated freeze-pump-thaw cycles ( 3 cycles) and the flask was back-filled with nitrogen. The reaction was then irradiated with a $4.4 \mathrm{~W}$ blue LED strip in a circle around the reaction flask (approximately $5 \mathrm{~cm}$ from the flask) and stirred at room temperature until 30\% conversion was obtained. Excess $\mathrm{Hg}$ (>100 equiv) was then added to the reaction mixture, 
which was degassed by repeated freeze-pump-thaw cycles ( 3 cycles), back-filled with nitrogen and irradiated. The reaction was shown to result in full conversion of starting material to afford the desired oxidized product.

\section{Additional Control Experiments}

Table S2. Additional control experiments for substrates $\mathbf{2}$ and $\mathbf{4 .}^{a}$

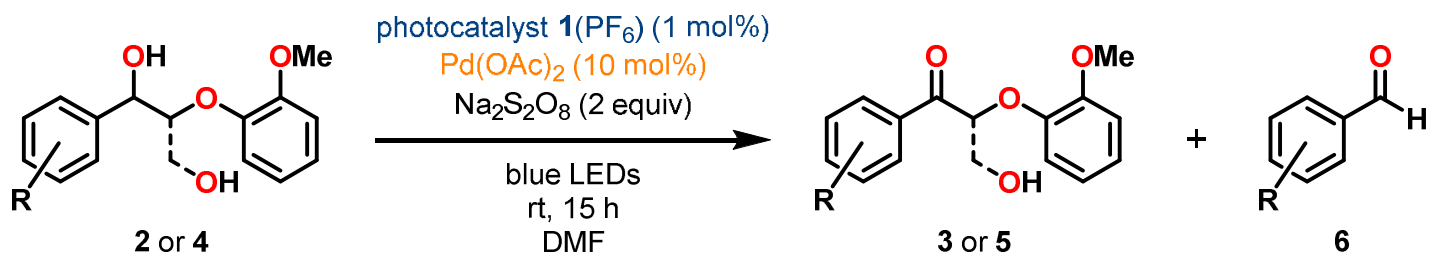

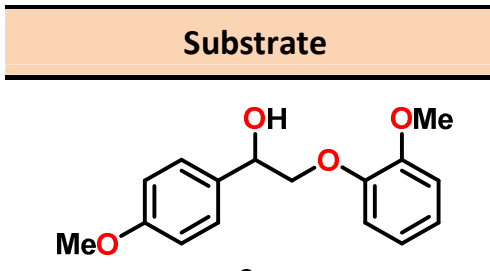

$\mathbf{2 a}$<smiles>COc1cc(OC)cc(OCC(O)c2ccc(OC)c(OC)c2)c1</smiles><smiles>COc1ccccc1OCC(O)c1ccccc1</smiles>

$2 f$<smiles>COc1ccc(C(O)C(CO)Oc2ccccc2OC)cc1</smiles>

$4 a$<smiles>COc1ccc(C(O)C(CO)Oc2ccccc2OC)cc1OC</smiles>

$\begin{array}{cc}\text { Conditions } & \text { Yield }^{b} \\ \text { as shown } & \text { 3a: } 90 \% \\ & \\ \text { no photocatalyst } & \\ & \text { 2a: } 15 \% \\ & 3 a: 20 \%\end{array}$

as shown

3d: $97 \%$

no photocatalyst ${ }^{c}$

2d: $21 \%$

as shown

2f: $60 \%$

3f: $33 \%$

no photocatalyst ${ }^{c}$

2f: $80 \%$

as shown

5a: $51 \%$

6a: $25 \%$

no photocatalyst ${ }^{c}$

6a: $14 \%$

as shown

5b: $55 \%$

6b: $38 \%$

no photocatalyst ${ }^{c}$

5b: $17 \%$

6b: $18 \%$ 


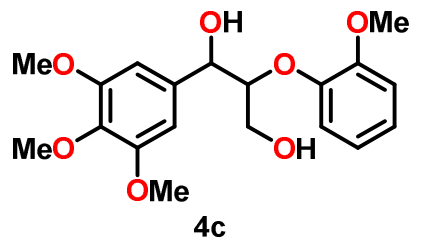

as shown

5c: $50 \%$

6c: $44 \%$

no photocatalyst ${ }^{c}$

5c: $16 \%$

6c: $5 \%$

${ }^{a}$ Reactions were run with photocatalyst $1\left(\mathrm{PF}_{6}\right)(1 \mathrm{~mol} \%), \mathrm{Pd}(\mathrm{OAc})_{2}(10 \mathrm{~mol} \%)$ and $\mathrm{Na}_{2} \mathrm{~S}_{2} \mathrm{O}_{8}$ (2 equiv) in DMF at room temperature under blue LED irradiation if not otherwise stated. ${ }^{b}$ Yields were obtained by ${ }^{1} \mathrm{H}$ NMR analyses of the crude reaction mixtures with $1,3,5$-trimethoxybenzene as an internal standard. ${ }^{c}$ Decomposition was observed. 


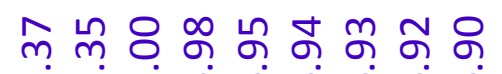
مَّ人

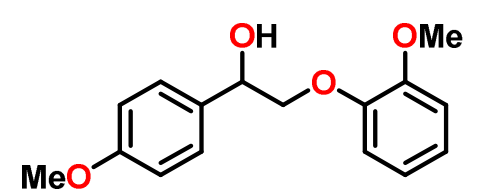

$2 a$

${ }^{1} \mathrm{H}$ NMR $\left(500 \mathrm{MHz}, \mathrm{CDCl}_{3}\right)$

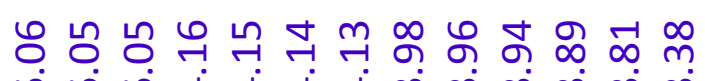

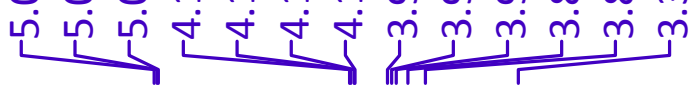

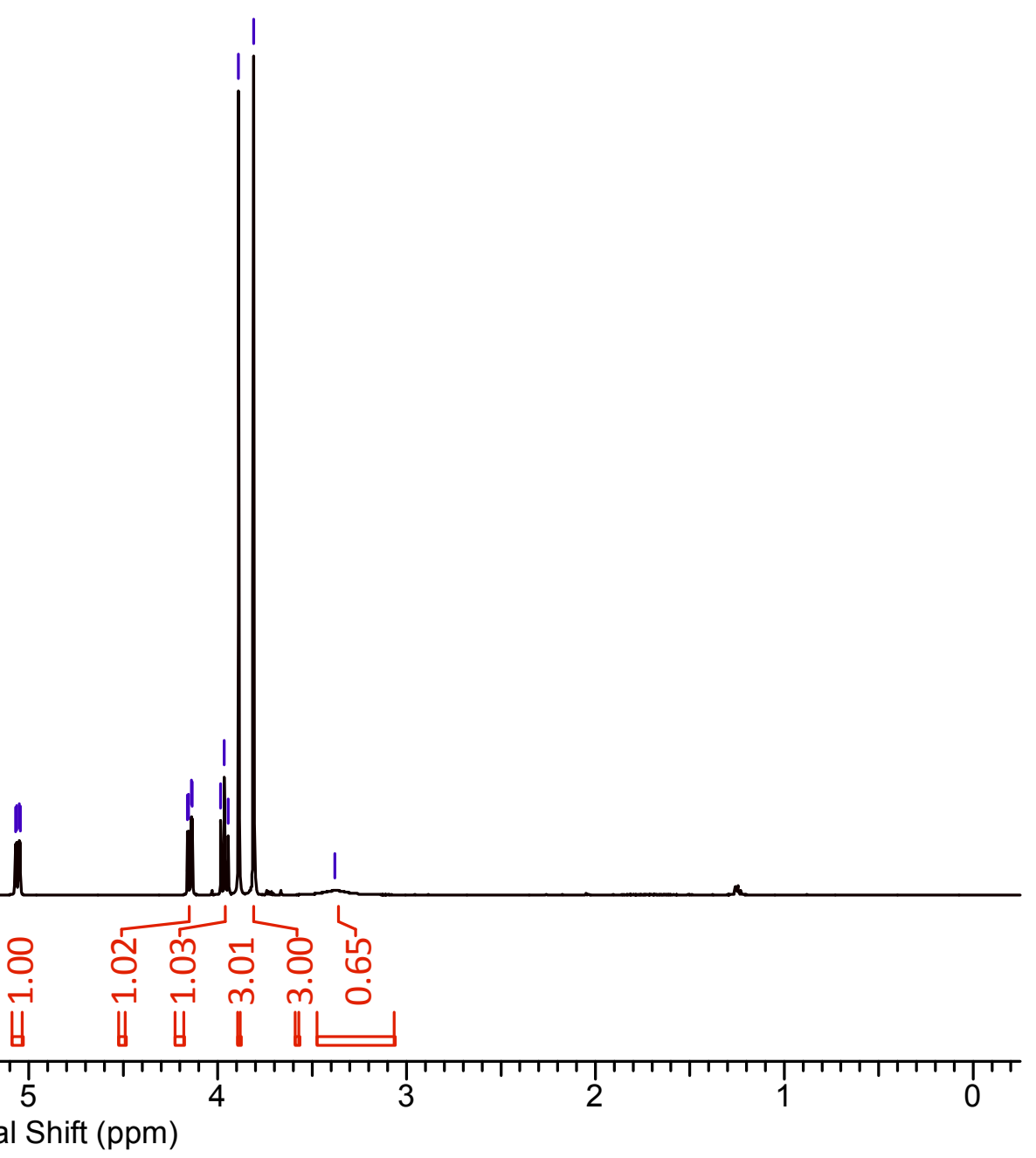



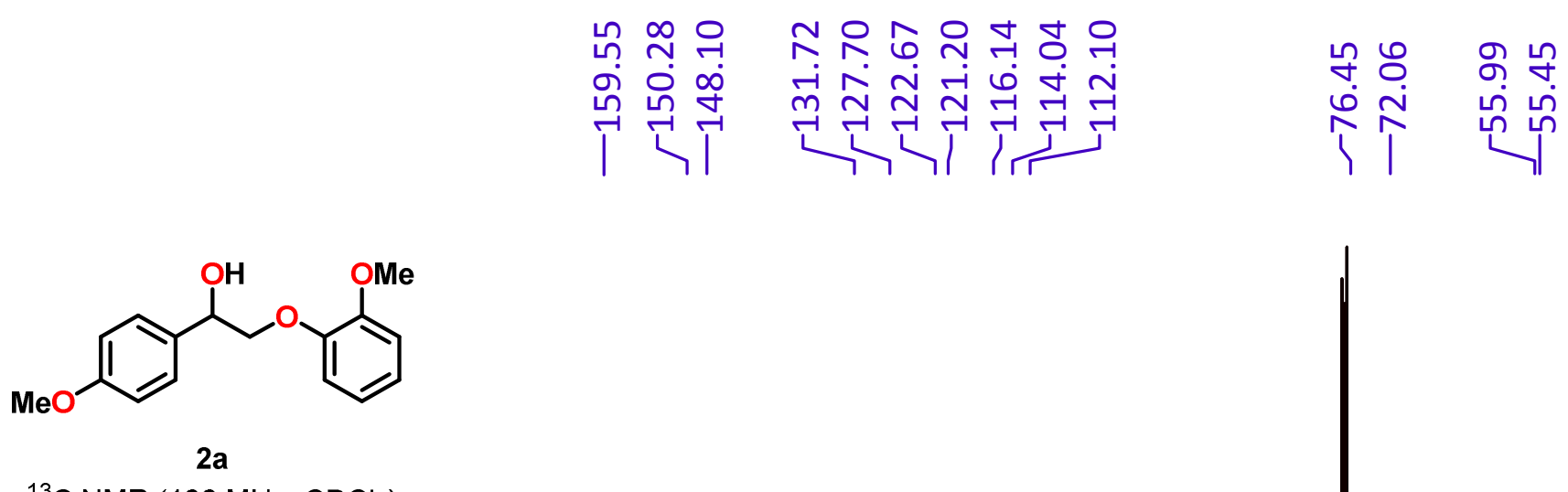

${ }^{13} \mathrm{C}$ NMR $\left(126 \mathrm{MHz}, \mathrm{CDCl}_{3}\right)$

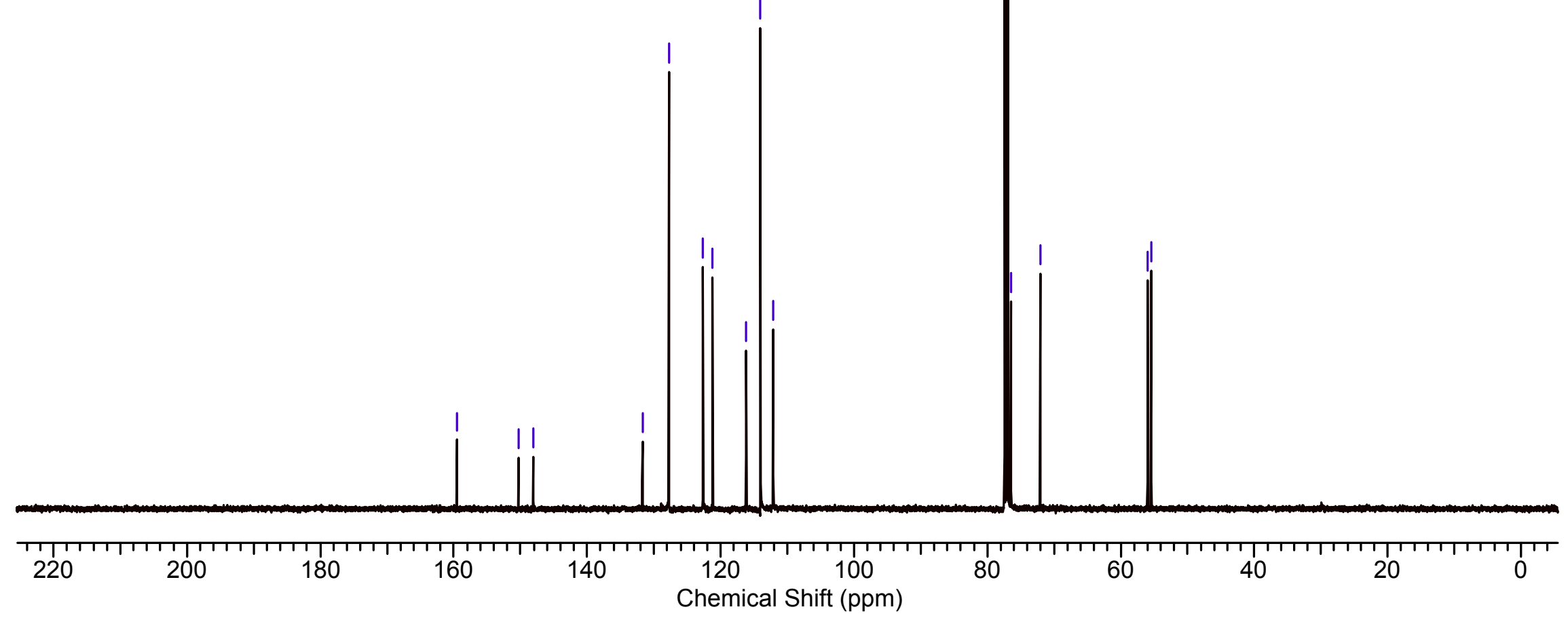




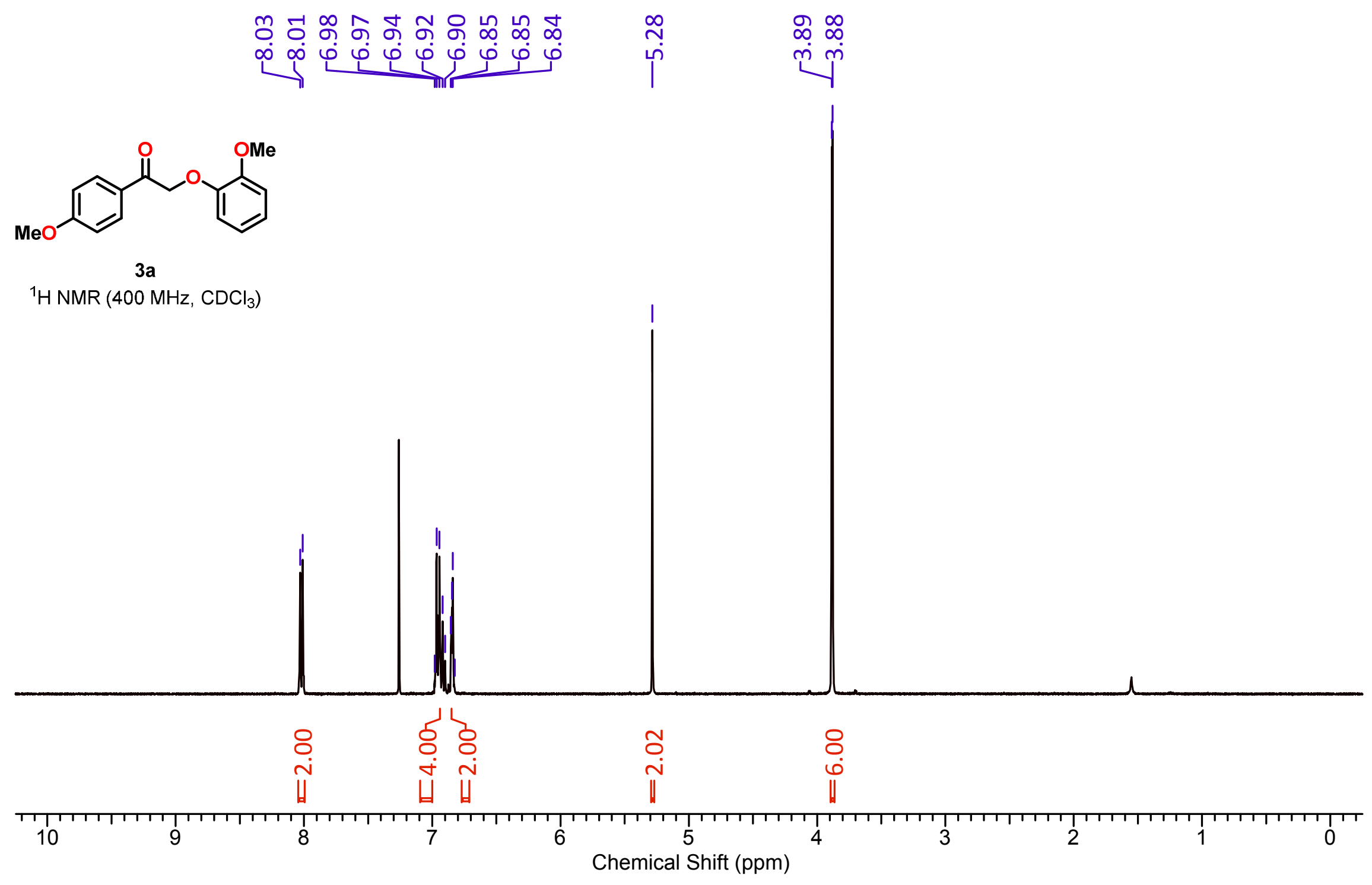




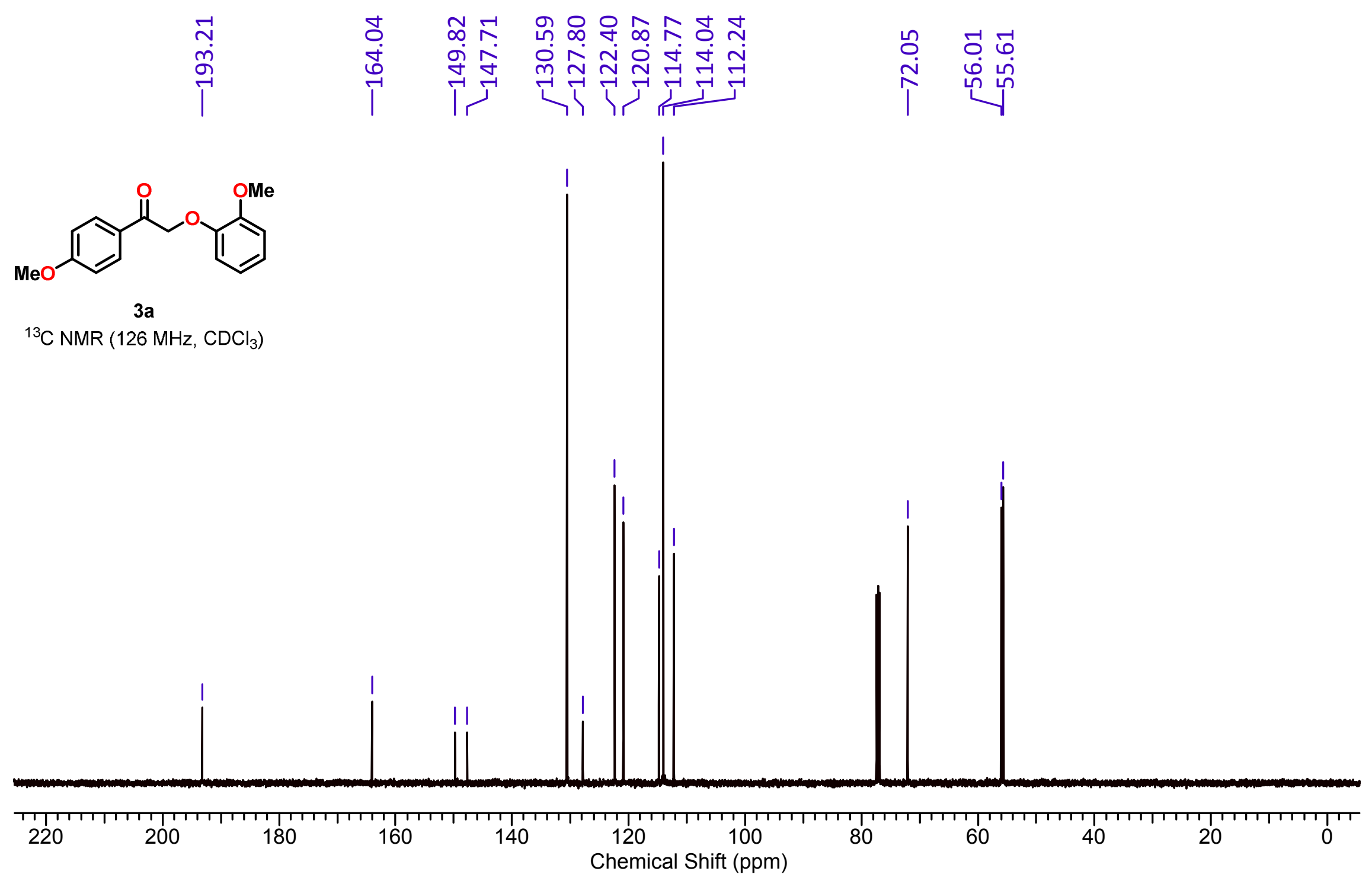




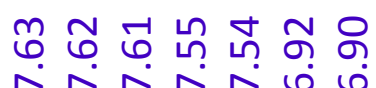

企亦苒

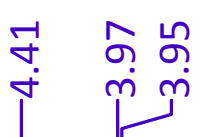

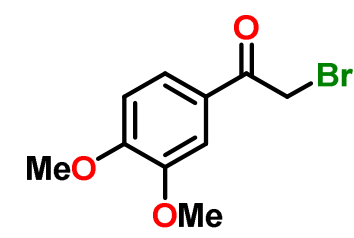

${ }^{1} \mathrm{H}$ NMR $\left(500 \mathrm{MHz}, \mathrm{CDCl}_{3}\right)$
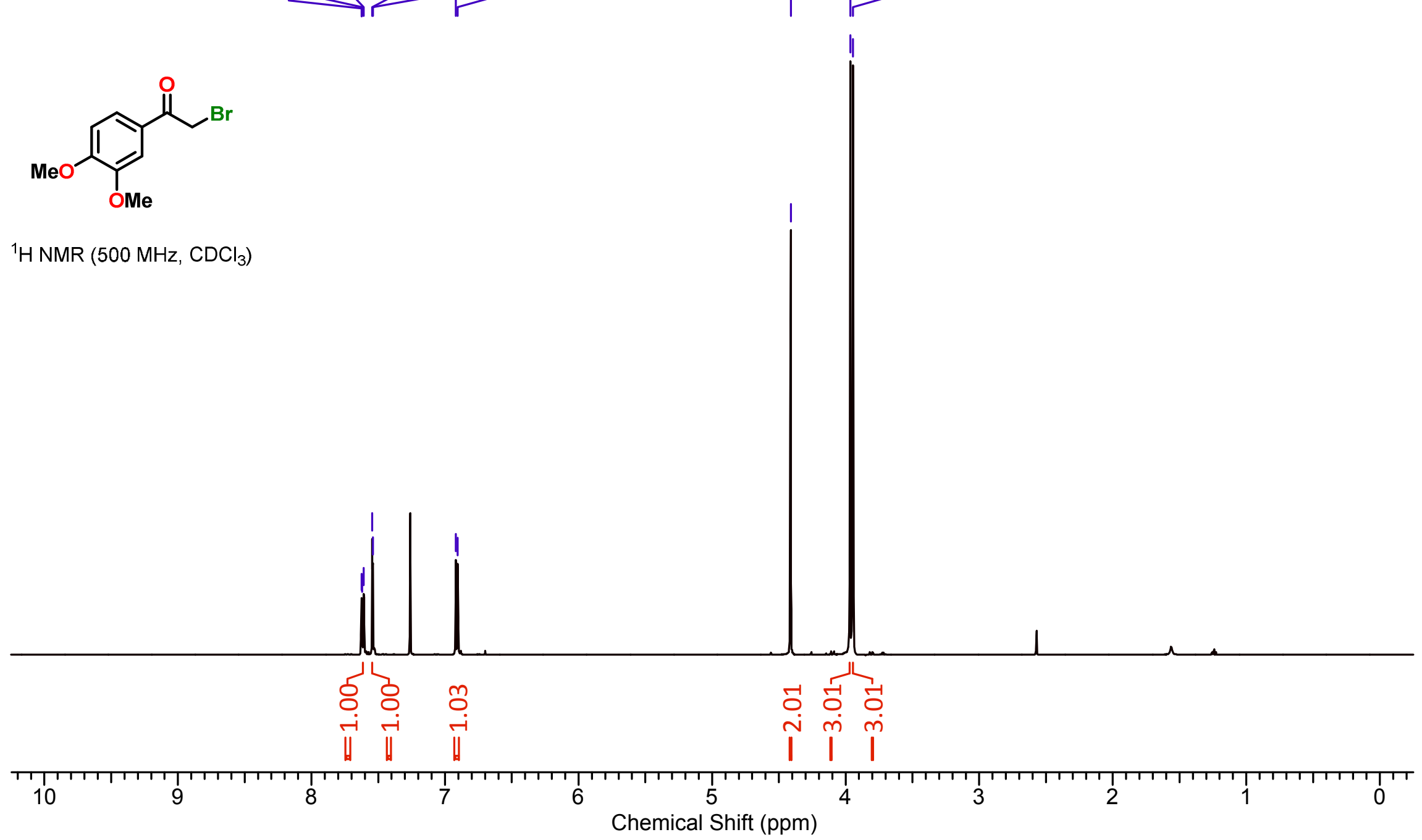


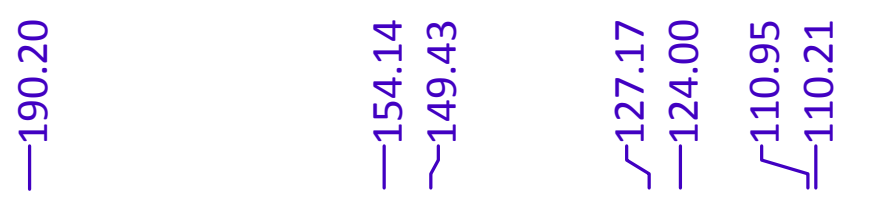

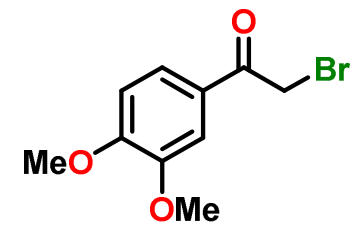

${ }^{13} \mathrm{C} \mathrm{NMR}\left(126 \mathrm{MHz}, \mathrm{CDCl}_{3}\right)$

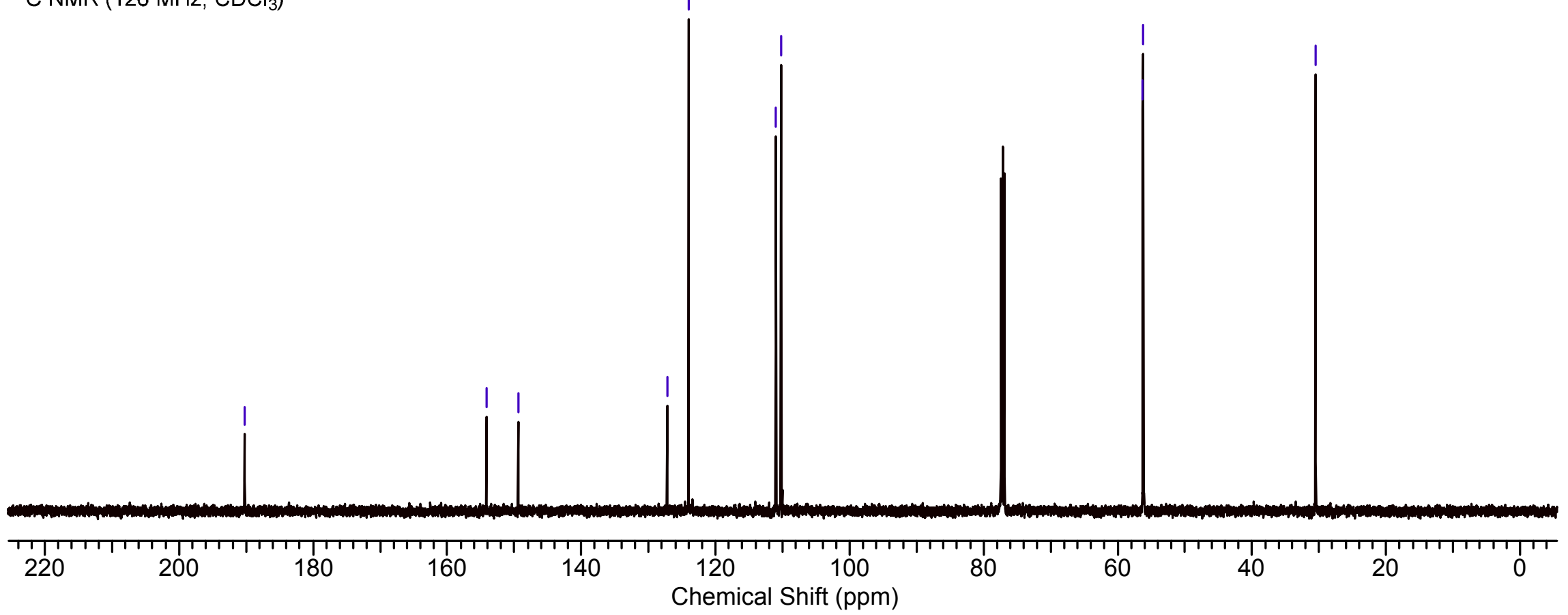




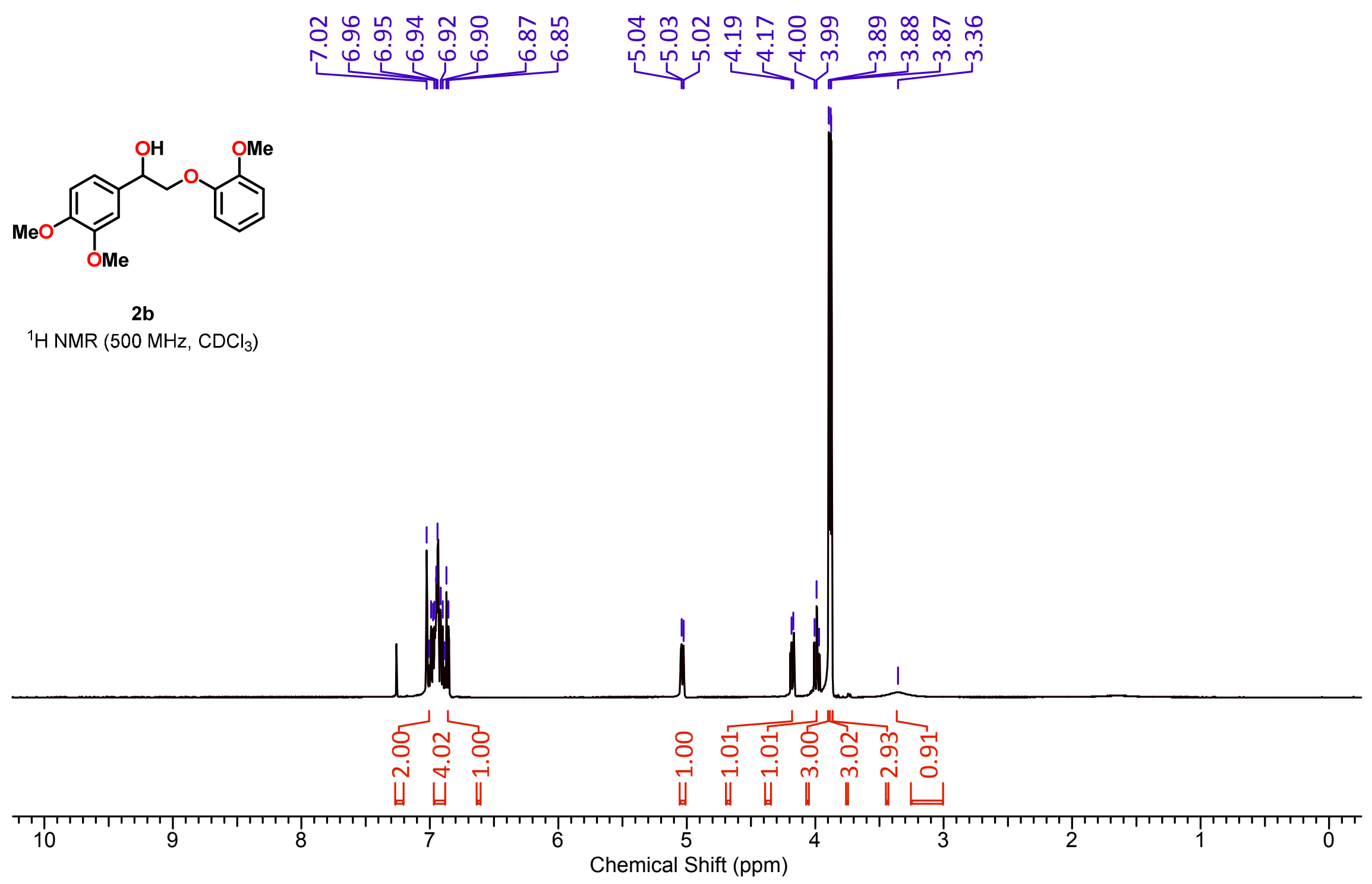


ปัน

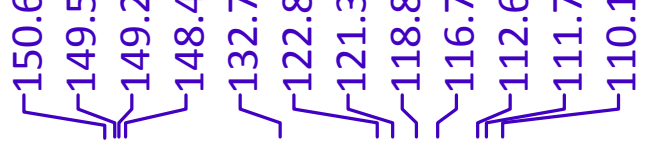

ำ $\stackrel{m}{\sim}$ 그ำ

ํํำ

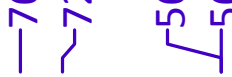

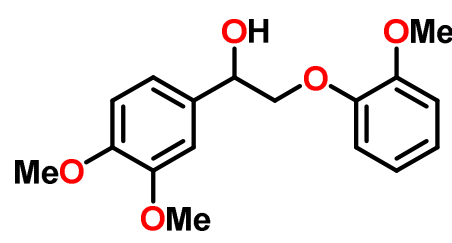

2b

$\left.{ }^{13} \mathrm{C} \mathrm{NMR} \mathrm{(126} \mathrm{MHz,} \mathrm{CDCl}_{3}\right)$

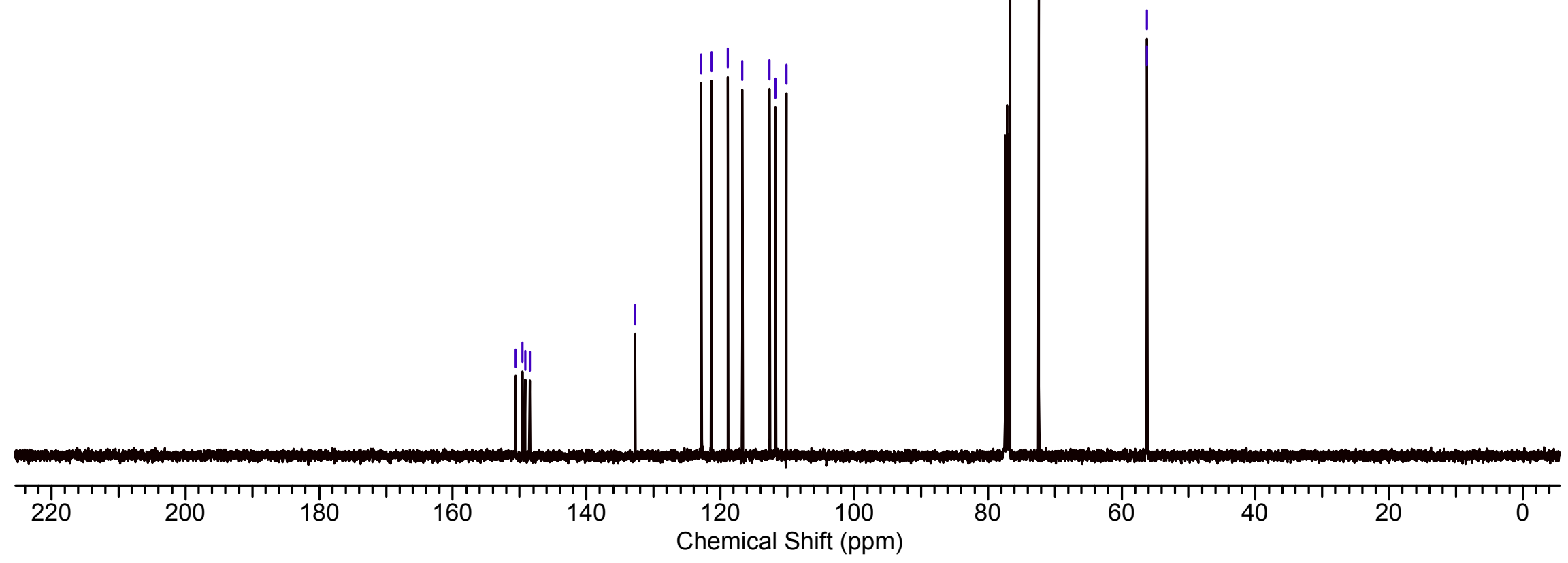




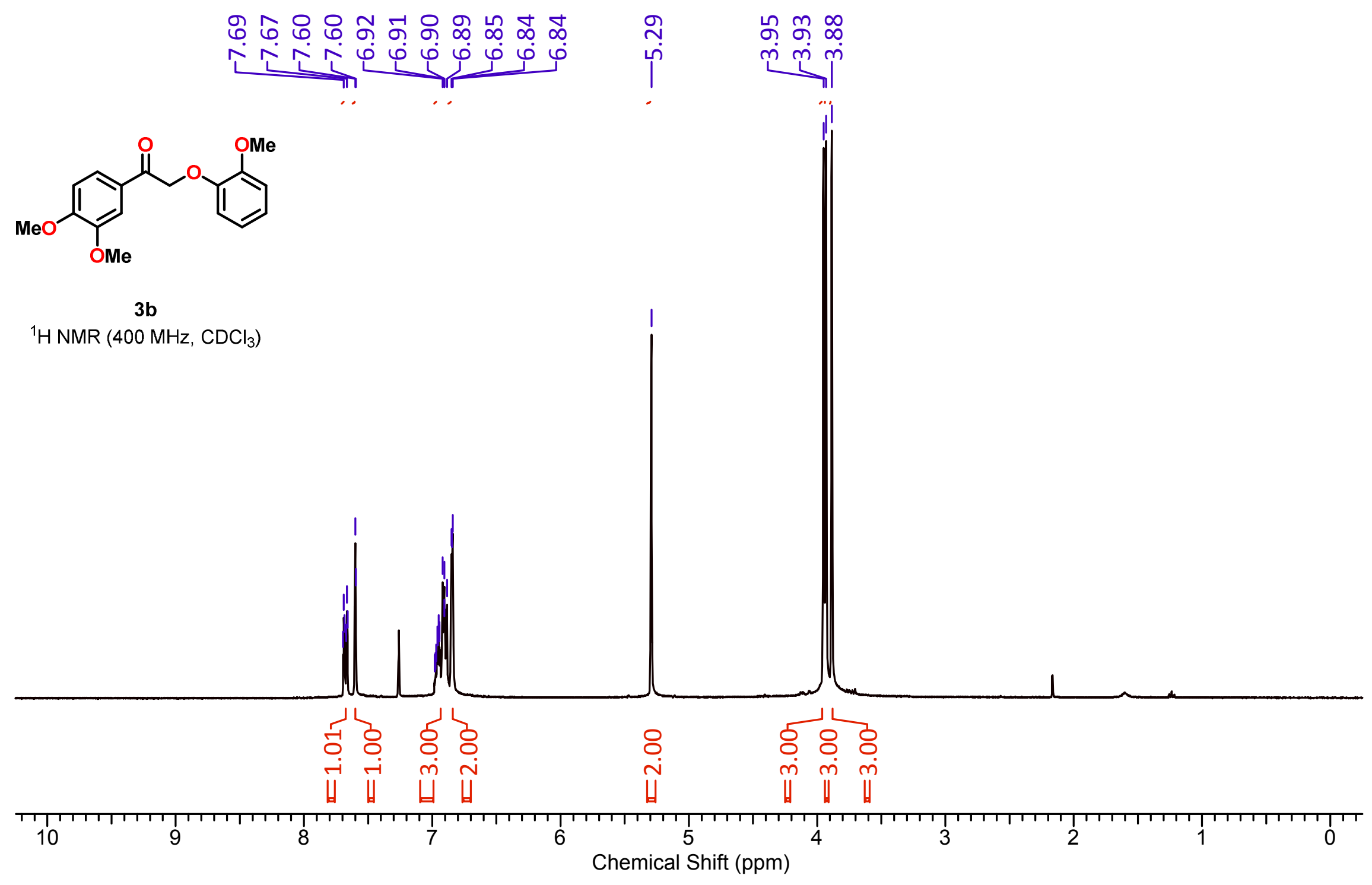




$$
\stackrel{\text { จุ }}{\text { ติ }}
$$
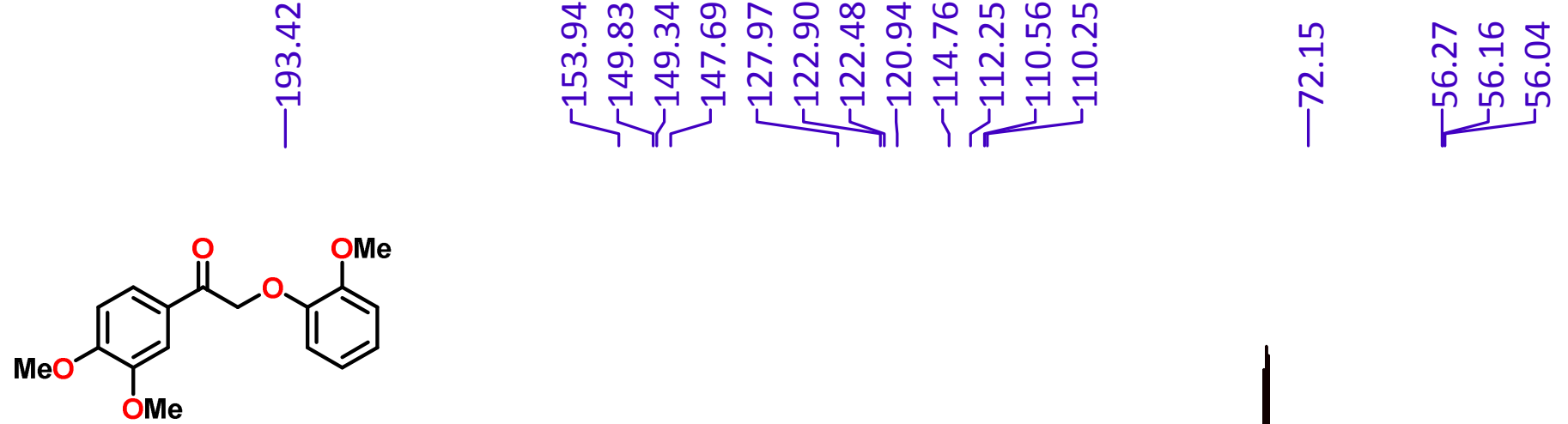

3b

$\left.{ }^{13} \mathrm{C} \mathrm{NMR} \mathrm{(126} \mathrm{MHz,} \mathrm{CDCl}_{3}\right)$

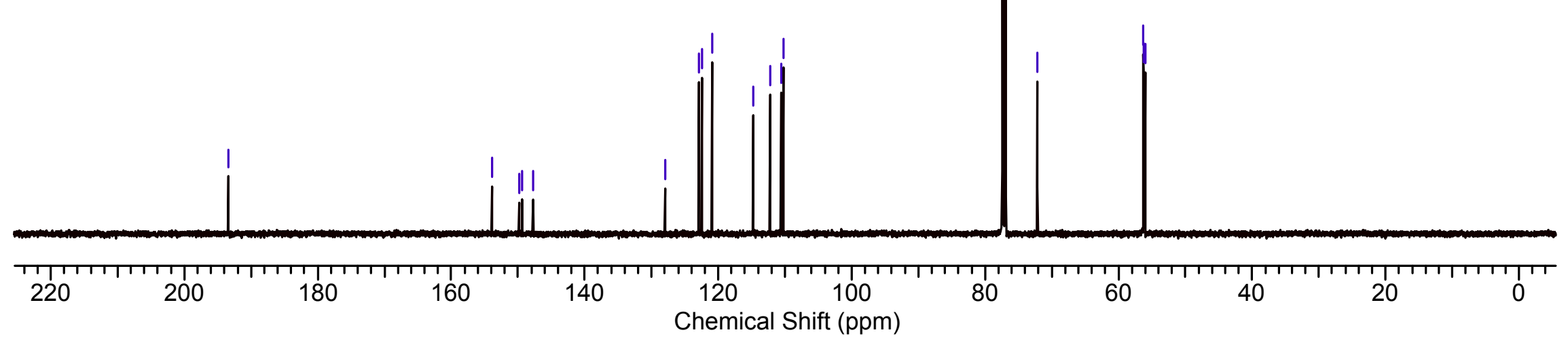




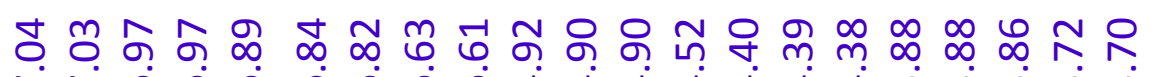

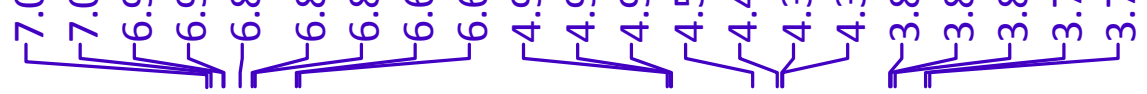

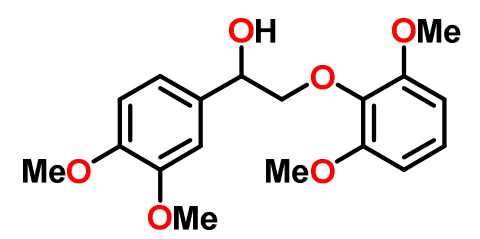

2c

${ }^{1} \mathrm{H} \mathrm{NMR}\left(500 \mathrm{MHz}, \mathrm{CDCl}_{3}\right)$

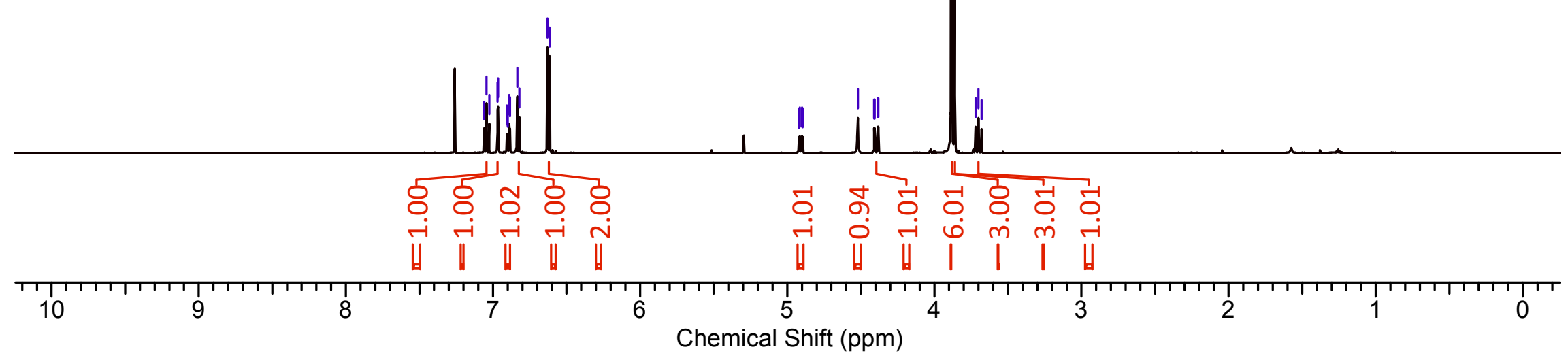


m 구 மำ

m $\infty$

ก

ґ

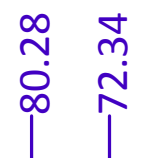

ฟ

ஸ்

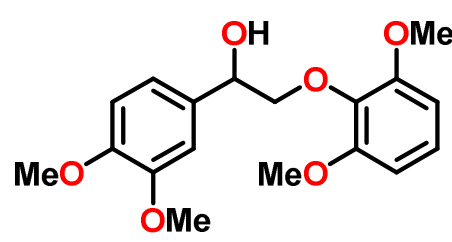

2c

${ }^{13} \mathrm{C}$ NMR (126 MHz, $\left.\mathrm{CDCl}_{3}\right)$

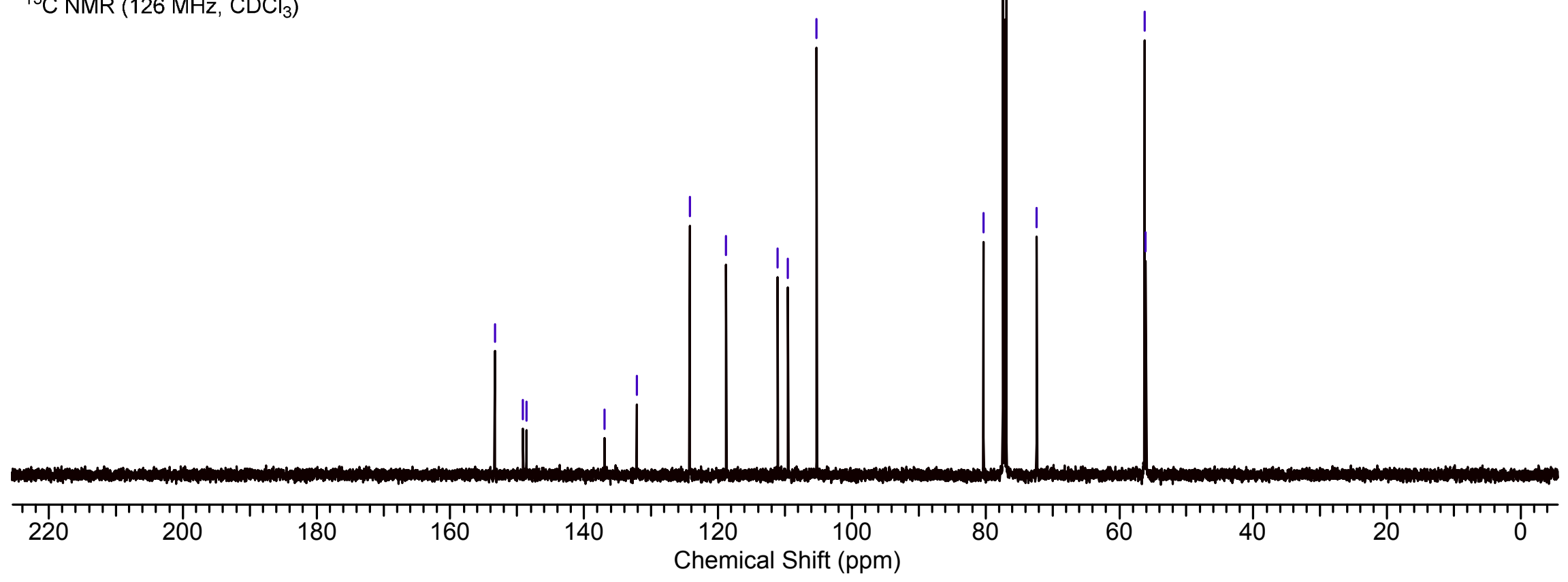




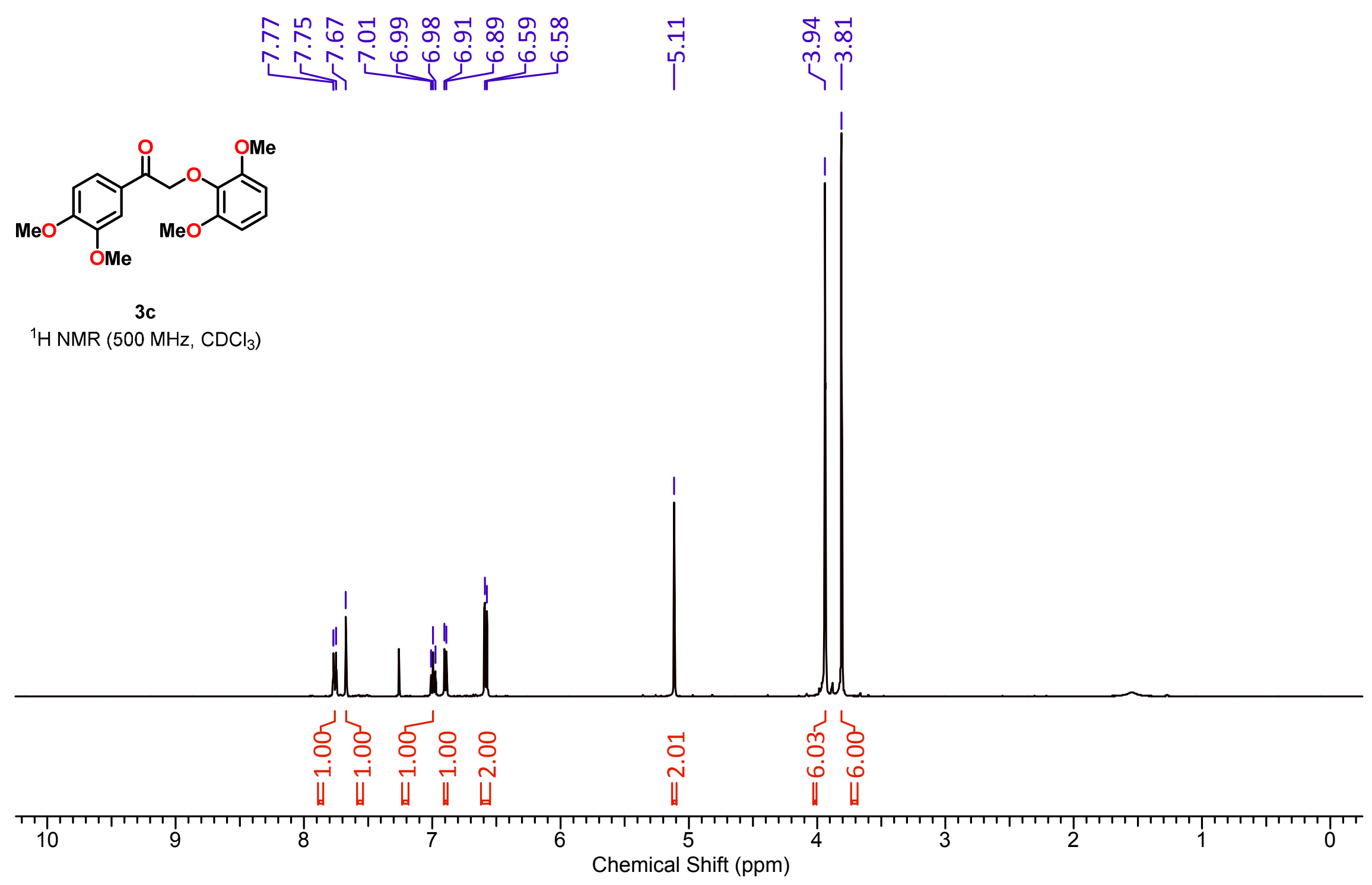




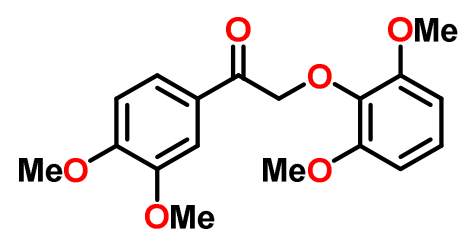

$3 c$

${ }^{13} \mathrm{C}$ NMR (126 MHz, $\left.\mathrm{CDCl}_{3}\right)$

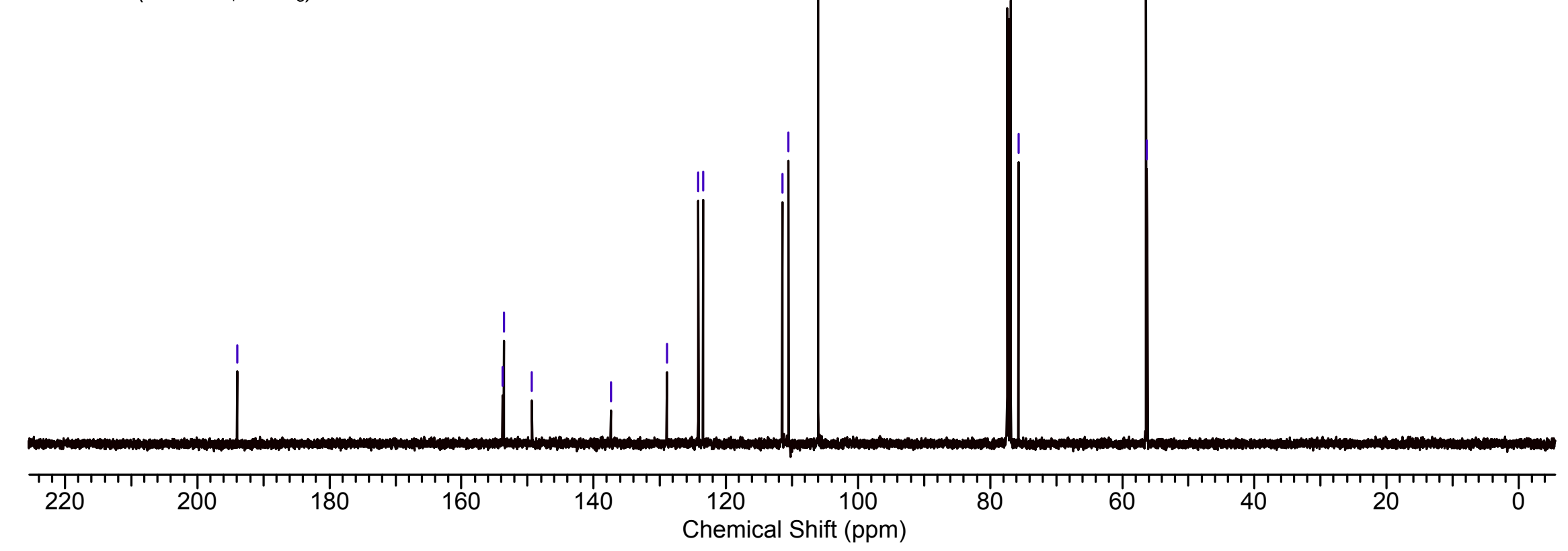




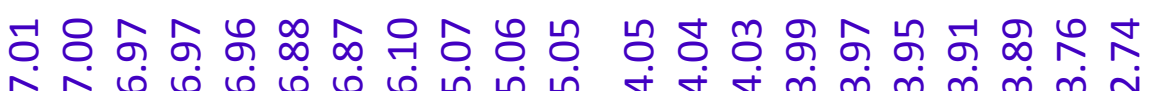

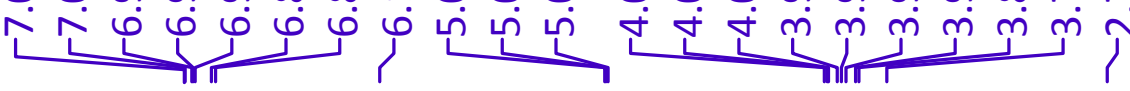

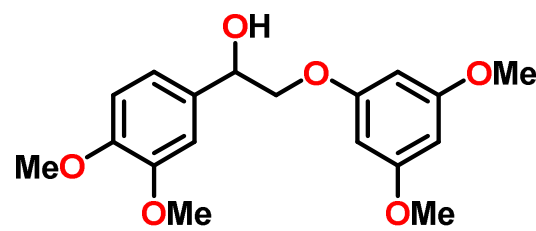

2d

${ }^{1} \mathrm{H} \mathrm{NMR}\left(500 \mathrm{MHz}, \mathrm{CDCl}_{3}\right)$

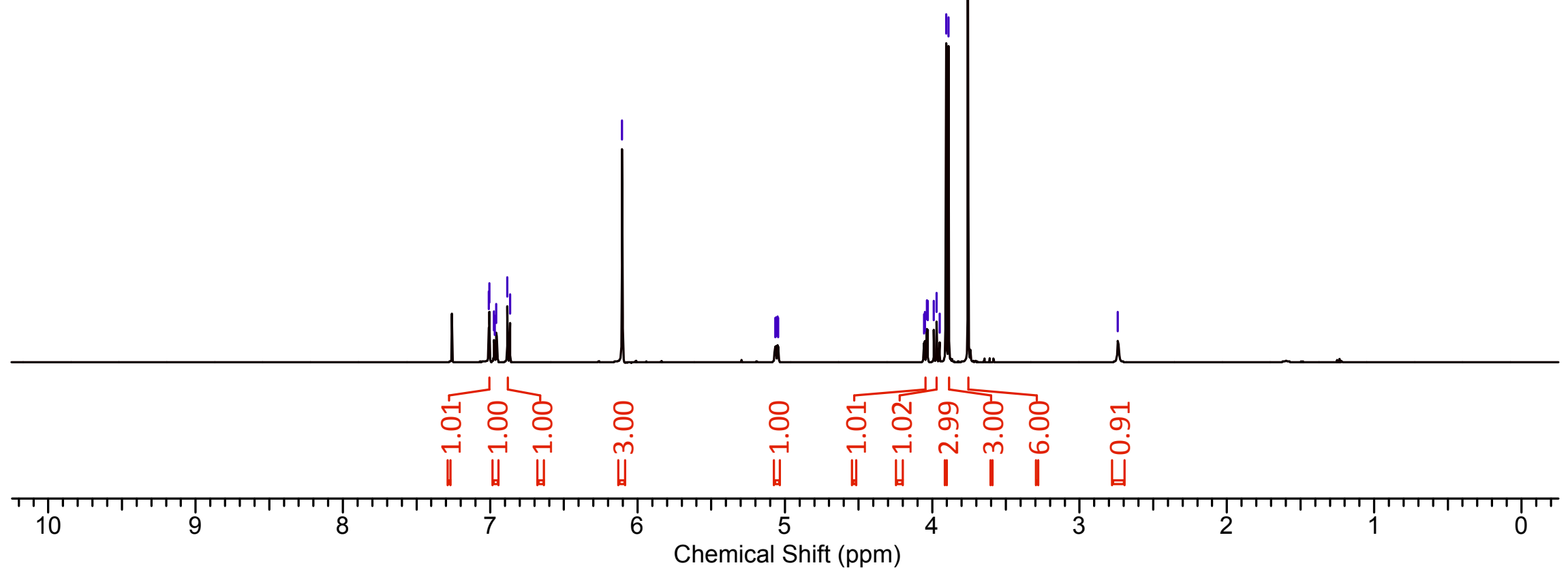




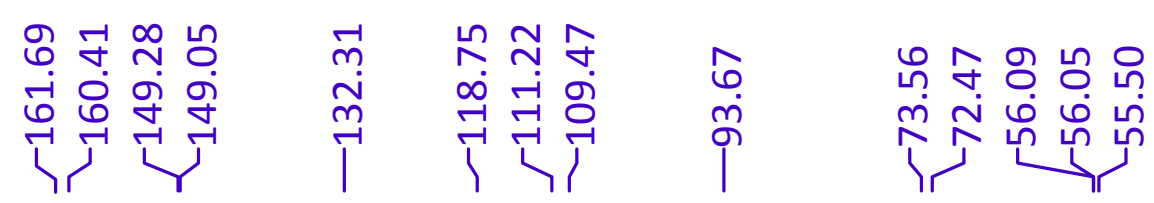

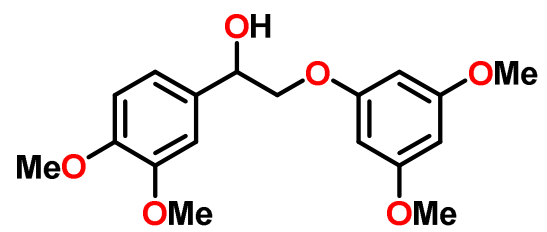

2d

${ }^{13} \mathrm{C}$ NMR (126 MHz, $\left.\mathrm{CDCl}_{3}\right)$

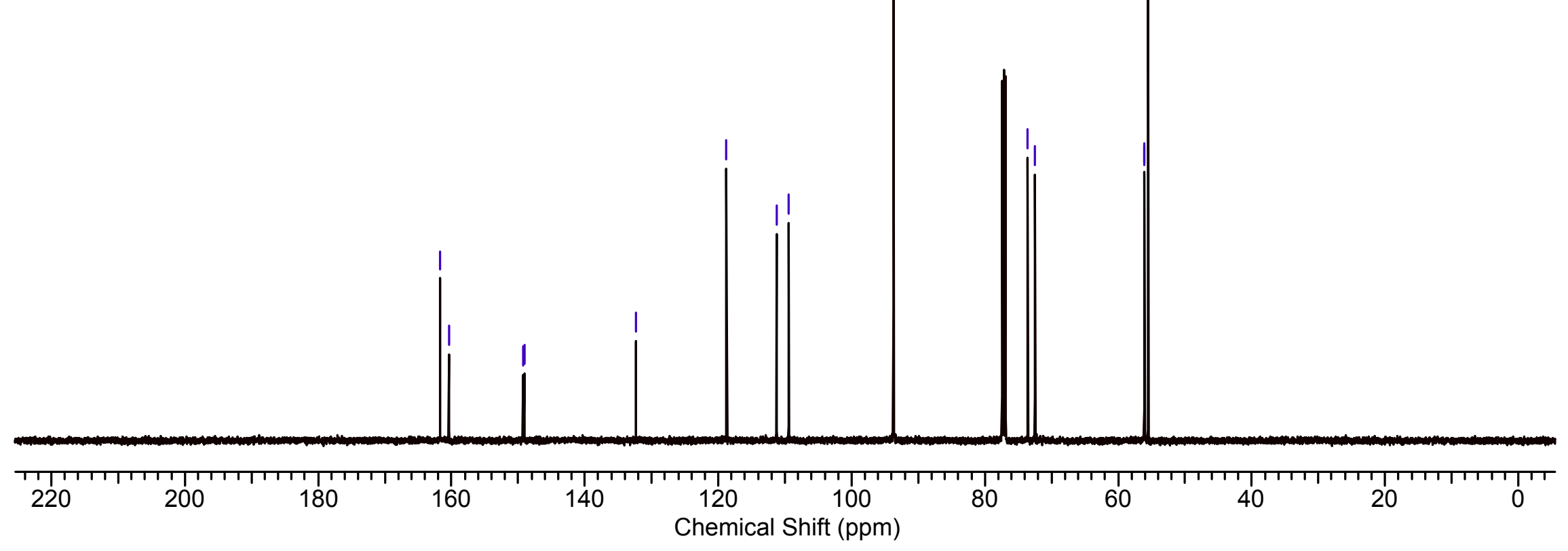




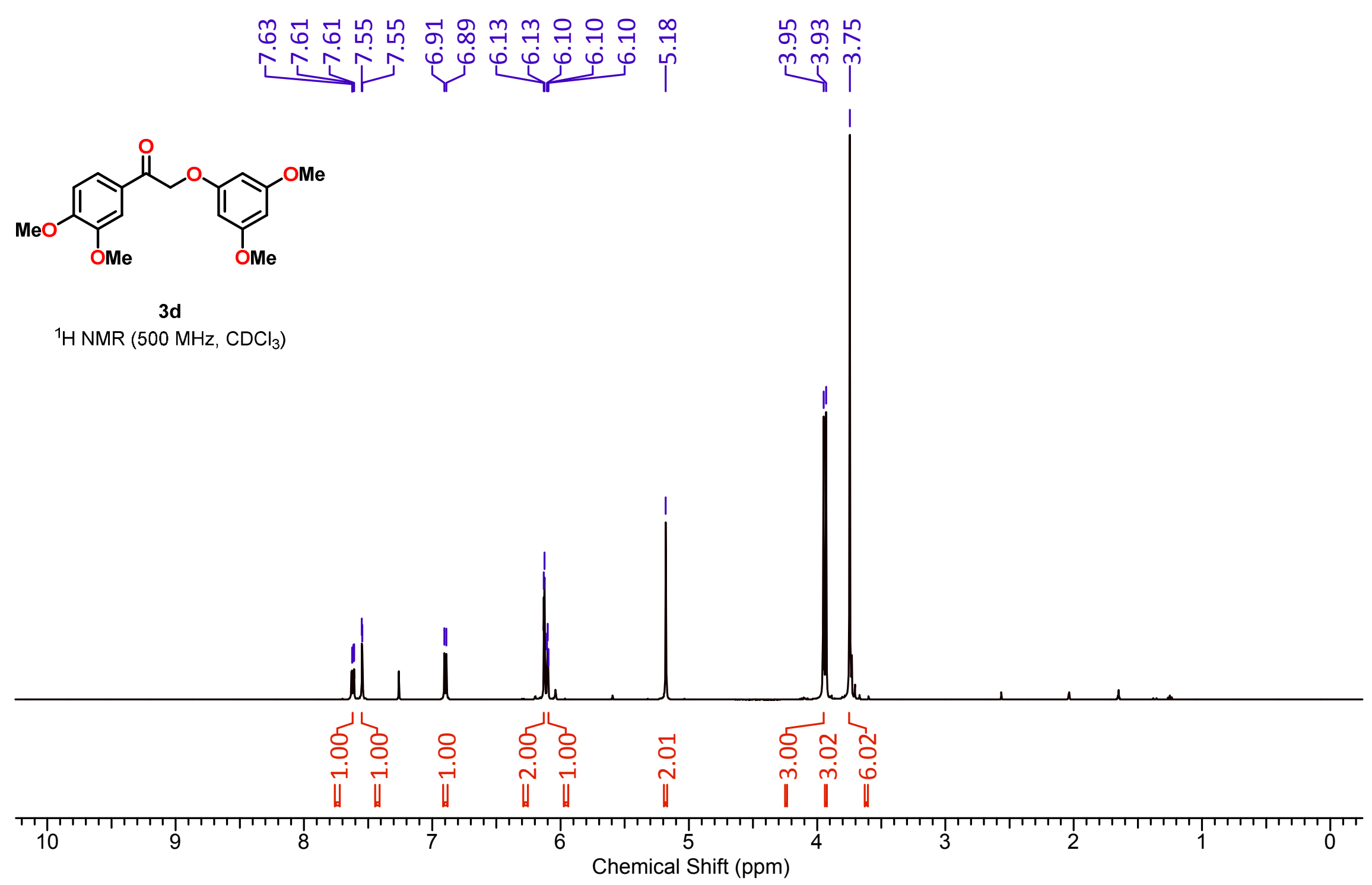



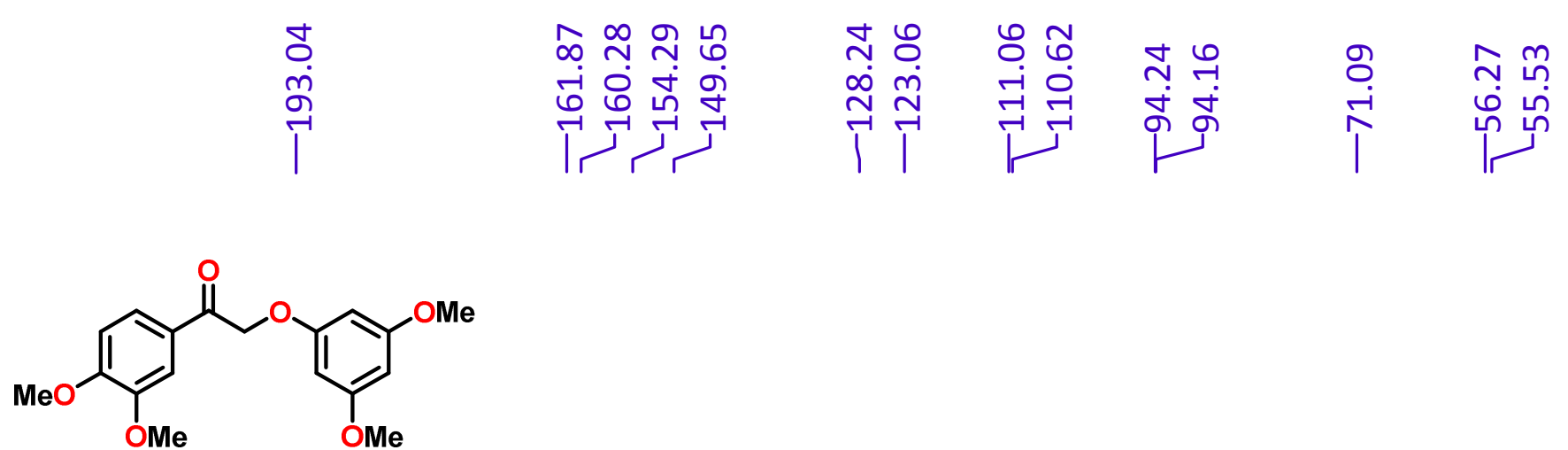

3d

${ }^{13} \mathrm{C} \mathrm{NMR}\left(126 \mathrm{MHz}, \mathrm{CDCl}_{3}\right)$

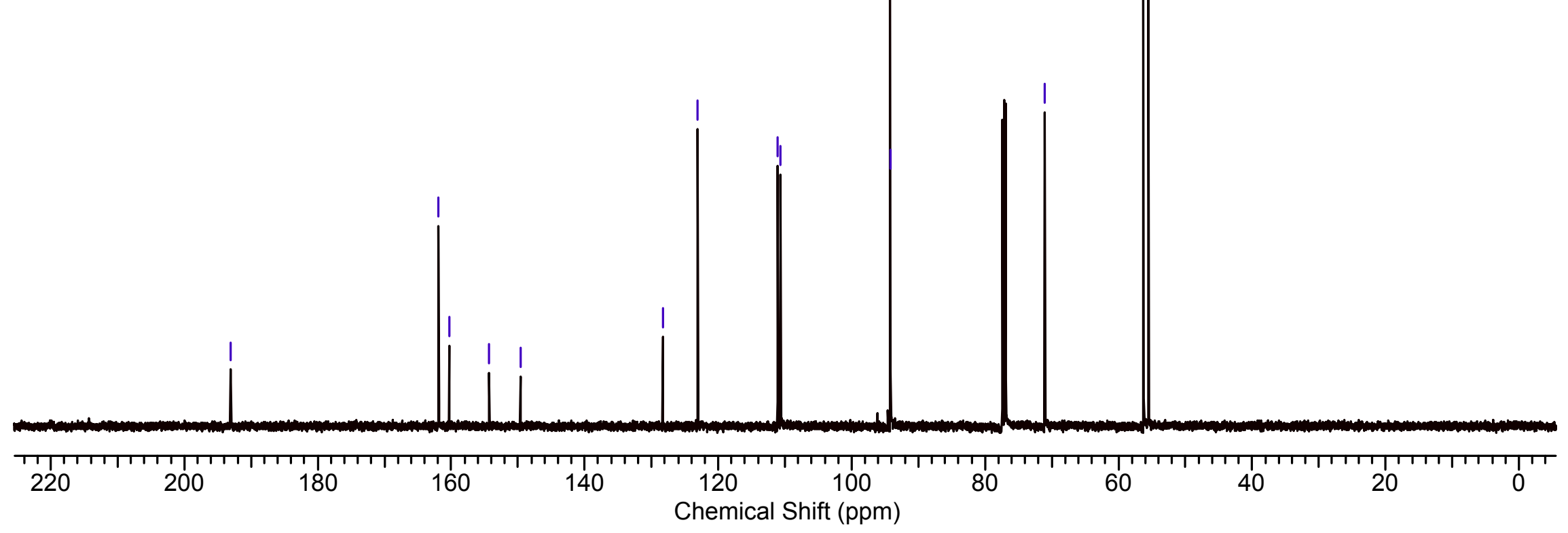




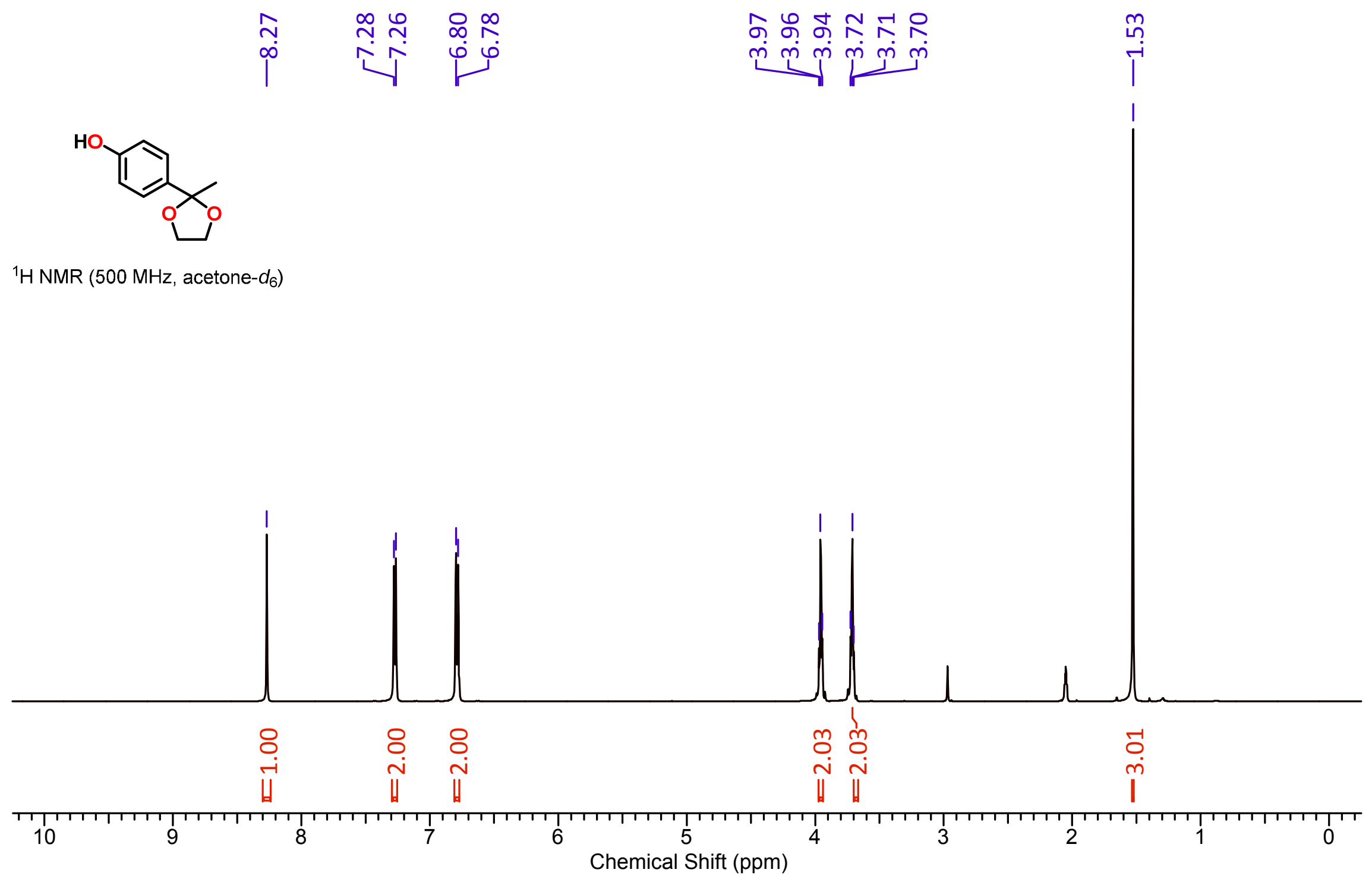



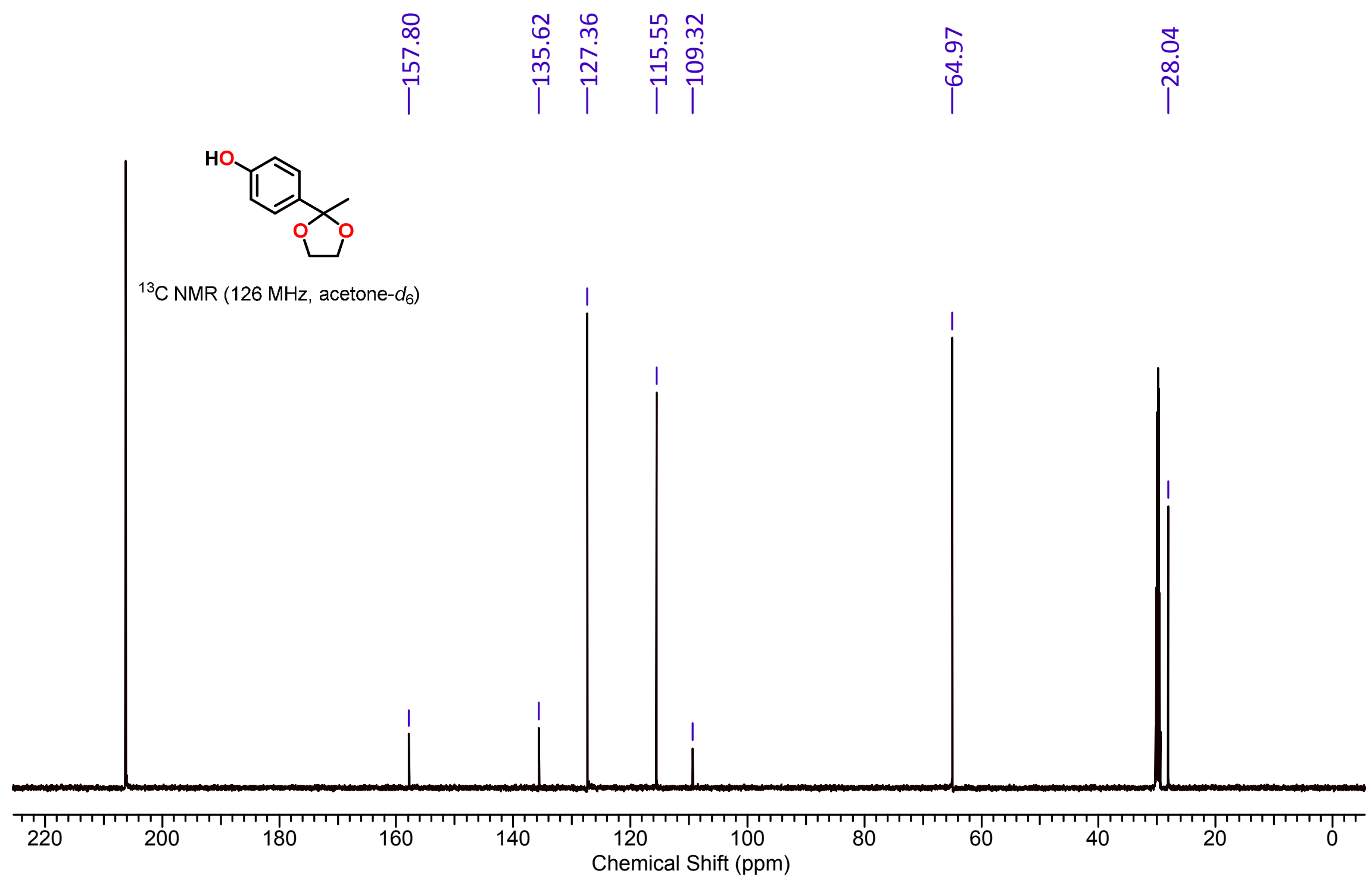


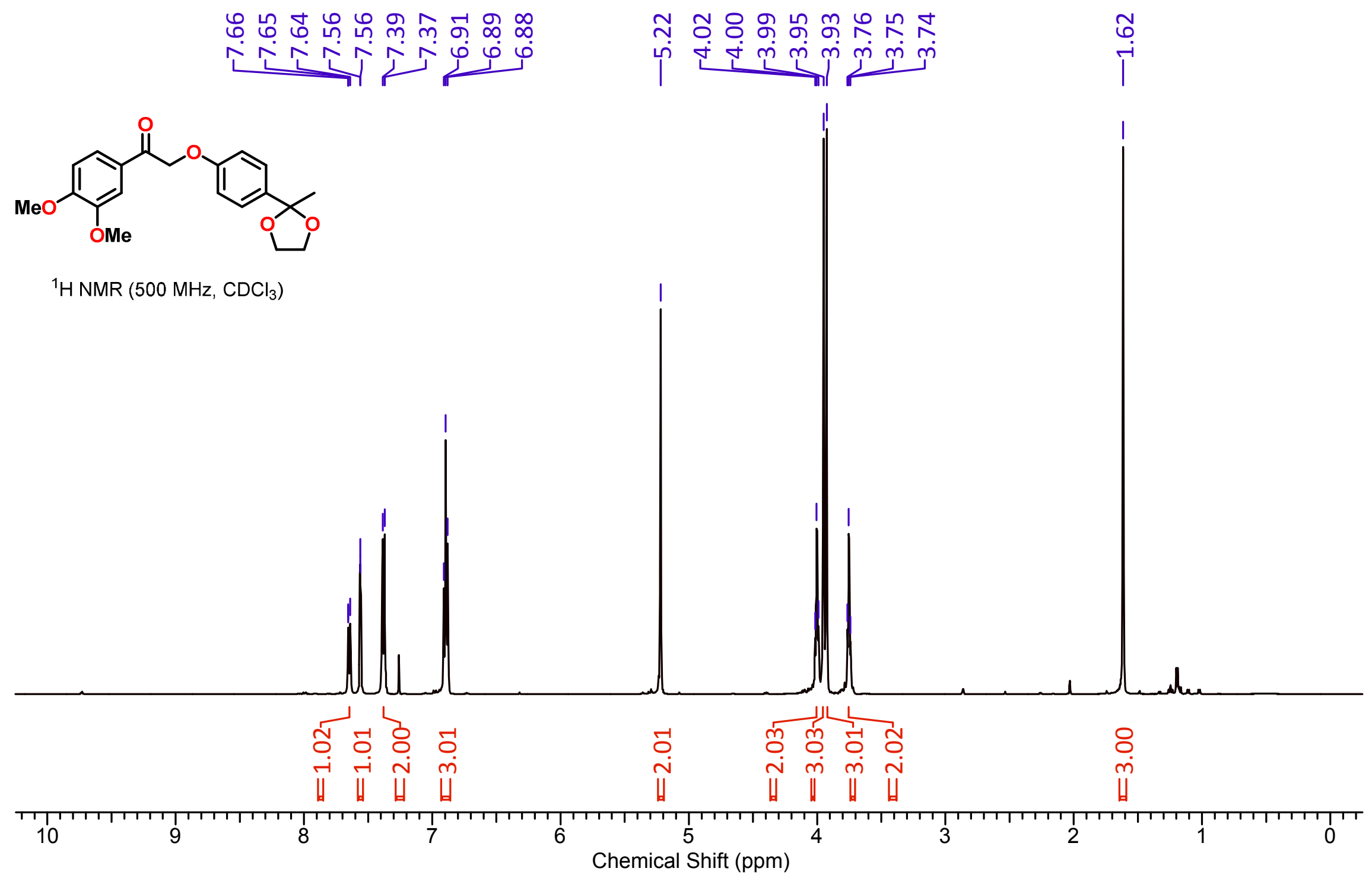




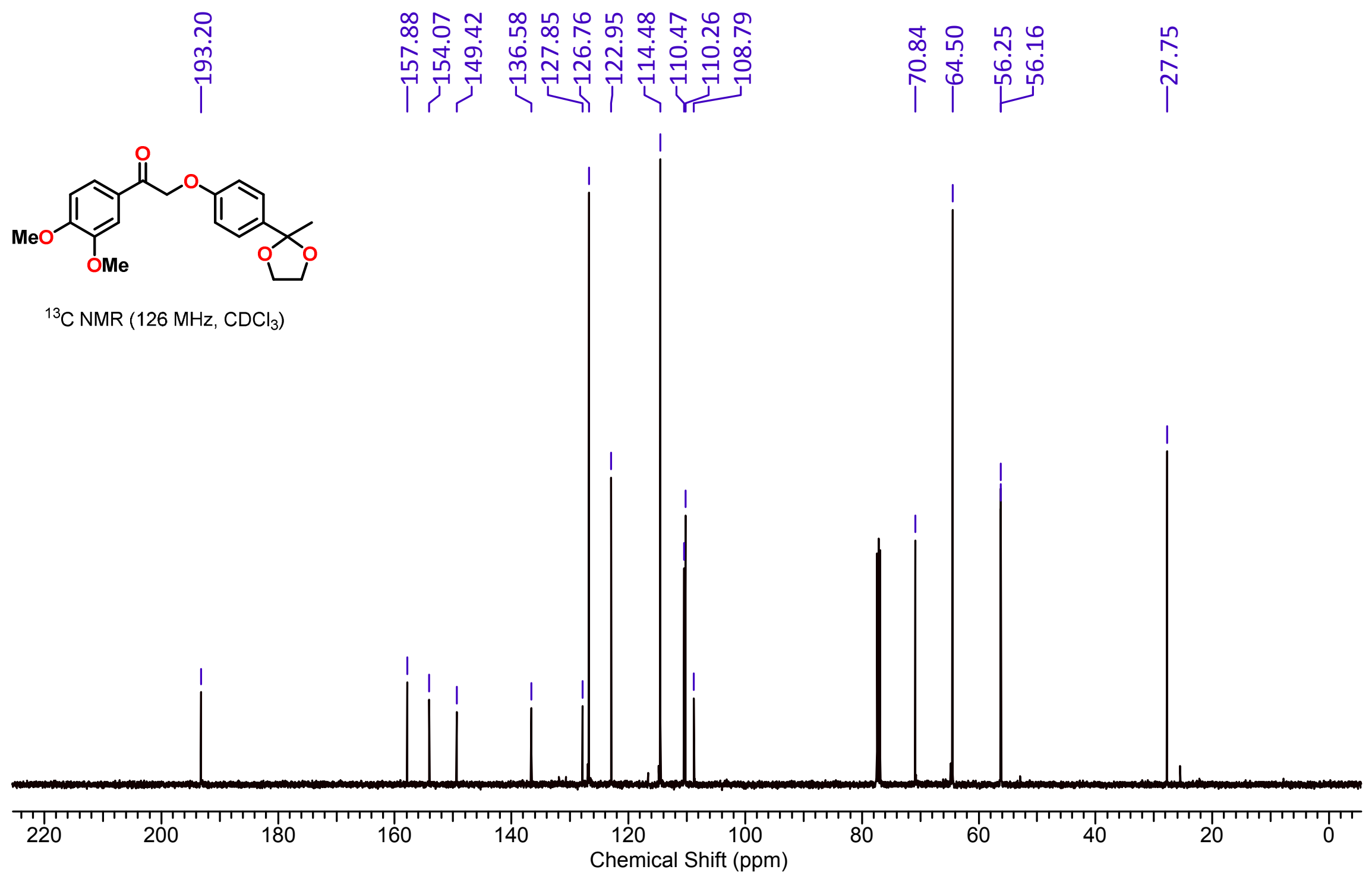




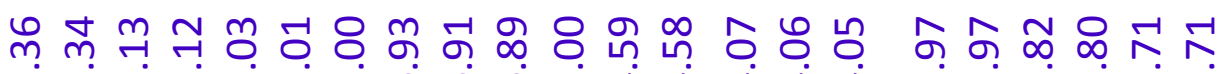

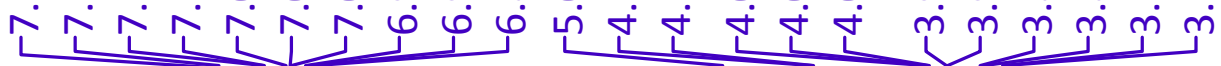

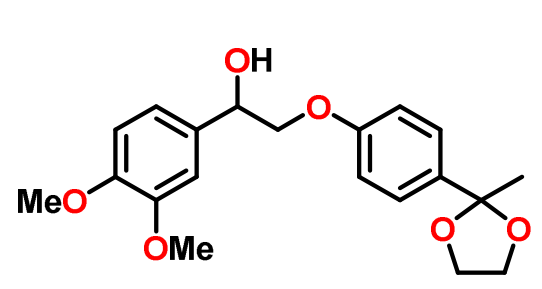

${ }^{1} \mathrm{H}$ NMR (400 MHz, acetone- $d_{6}$ )
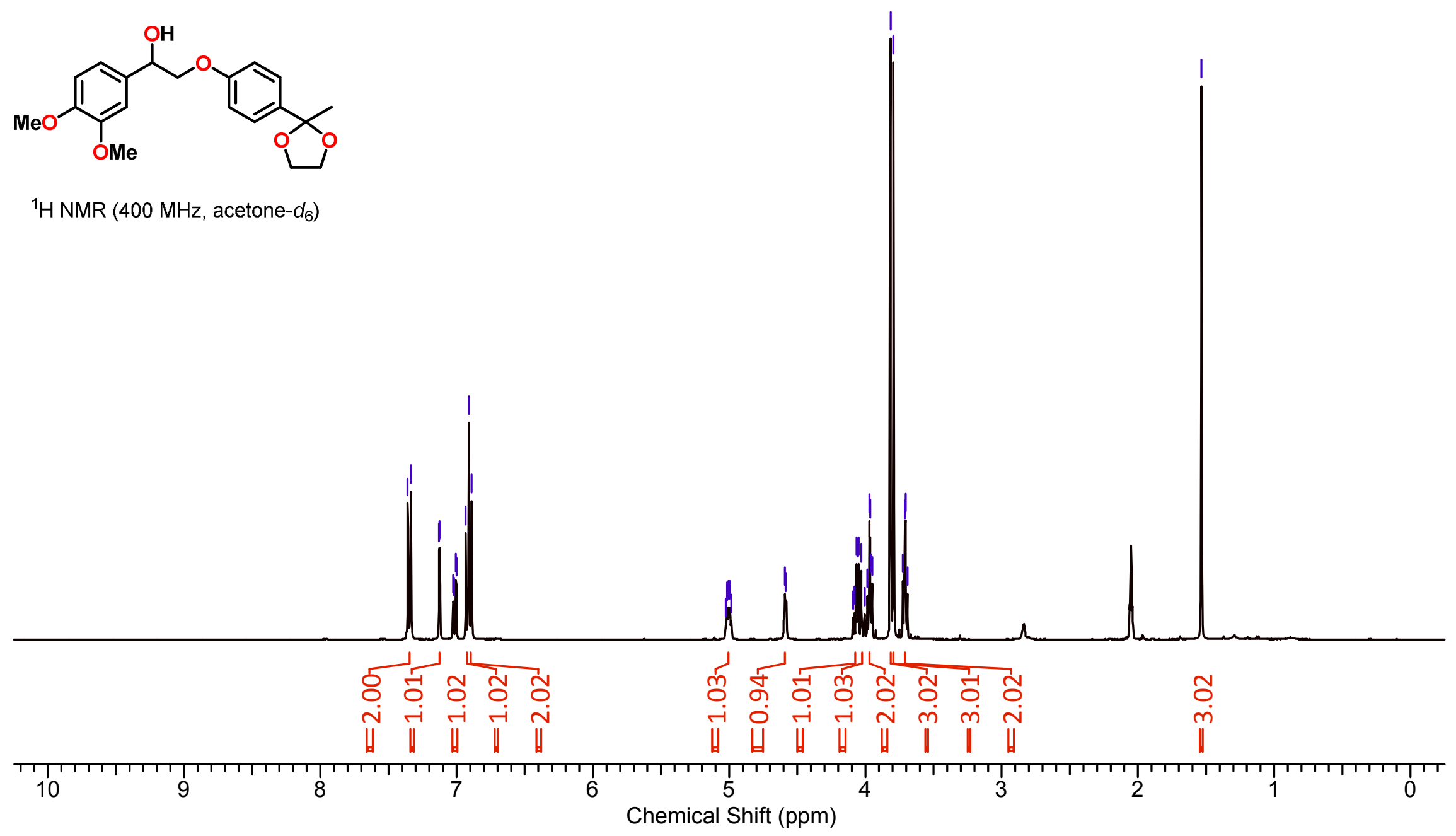

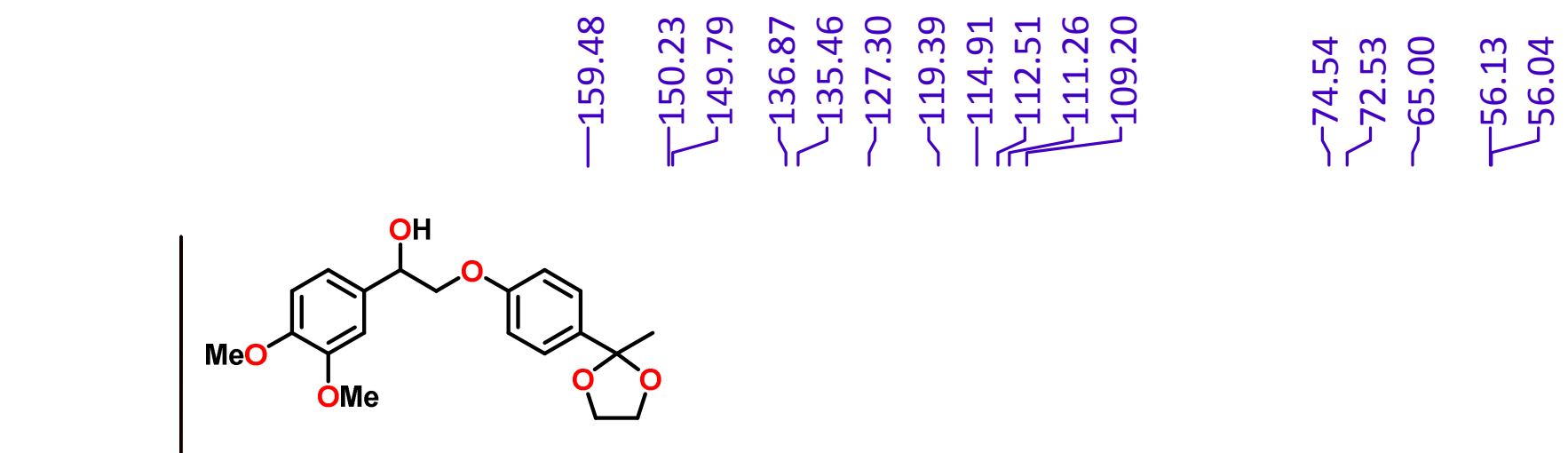

${ }^{13} \mathrm{C}$ NMR $\left(126 \mathrm{MHz}\right.$, acetone- $\left.d_{6}\right)$

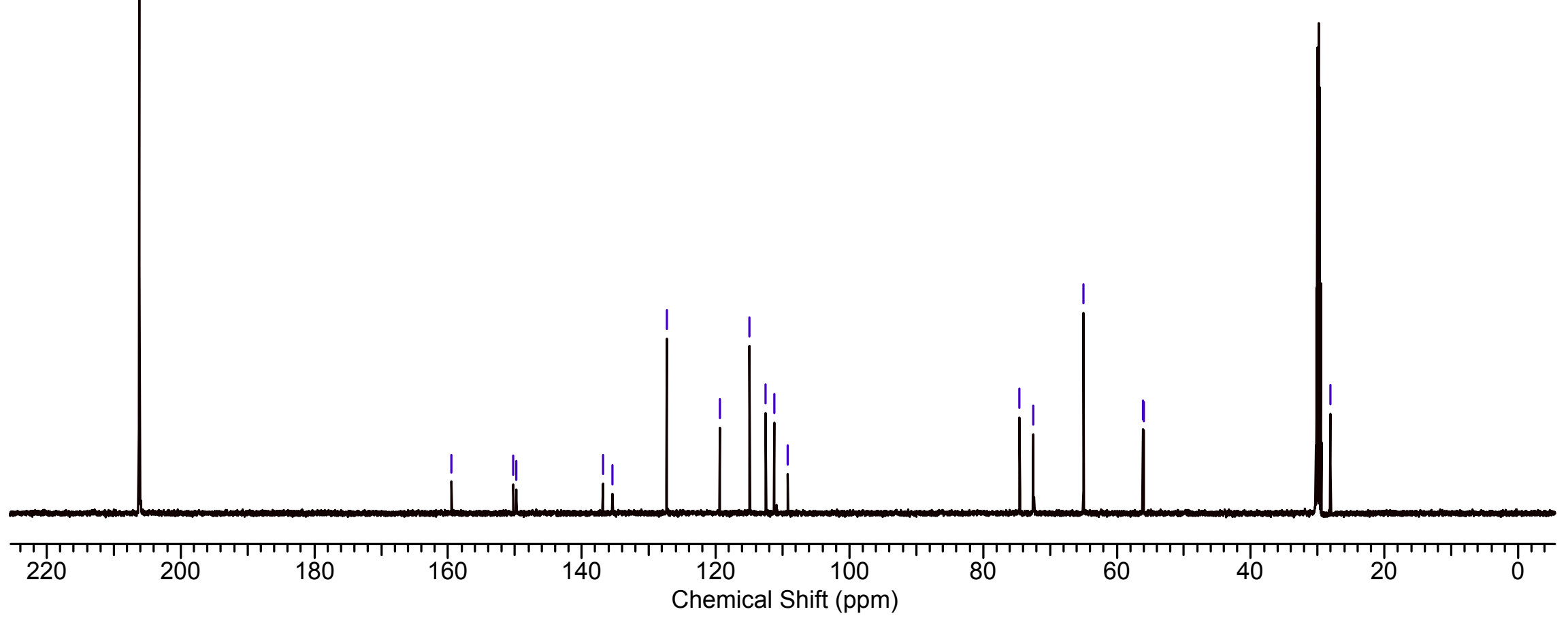




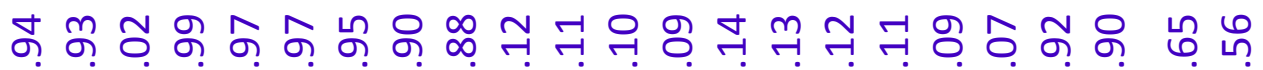

रิ $\hat{\imath}$

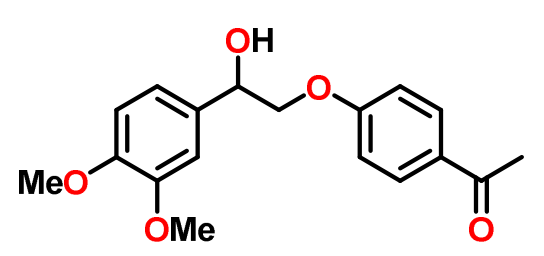

$2 \mathrm{e}$

${ }^{1} \mathrm{H}$ NMR $\left(500 \mathrm{MHz}, \mathrm{CDCl}_{3}\right)$

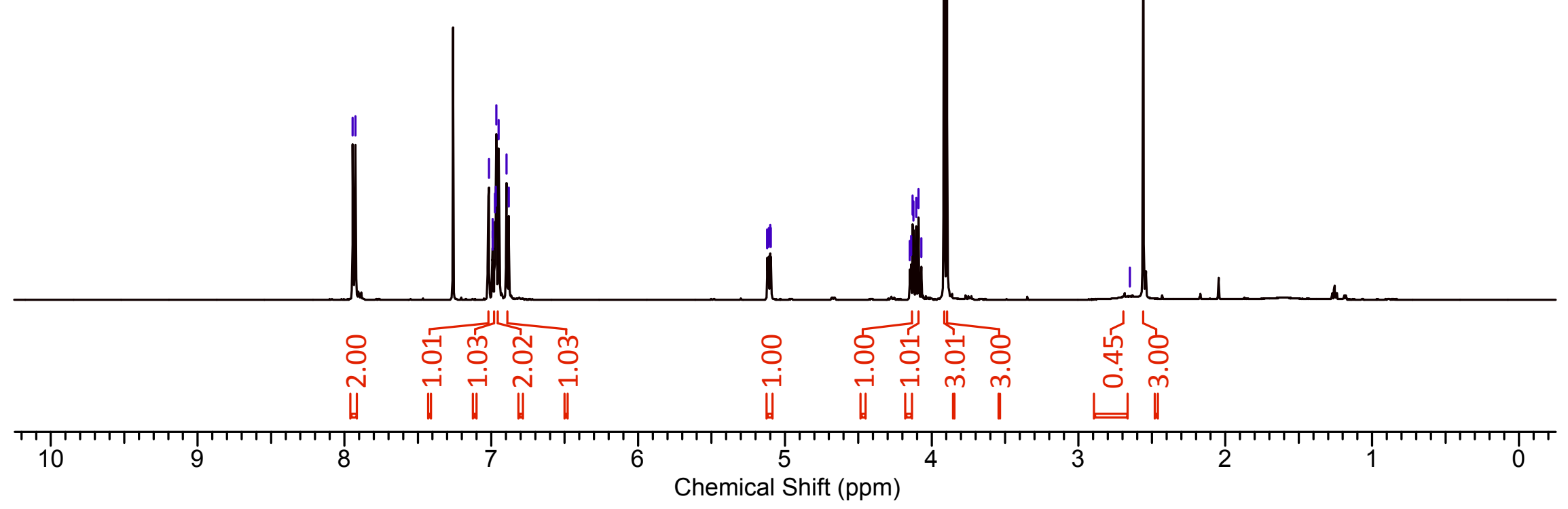




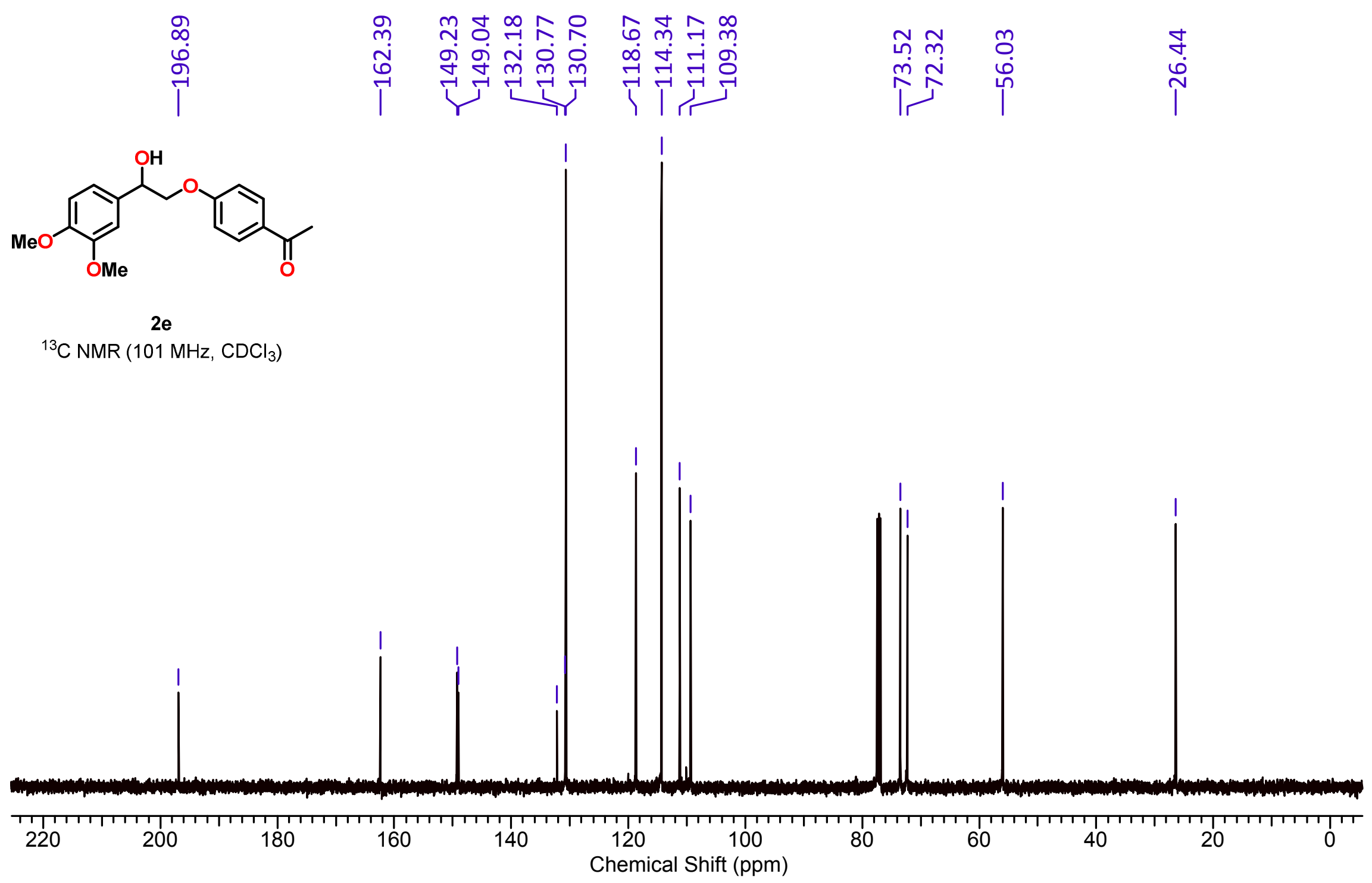




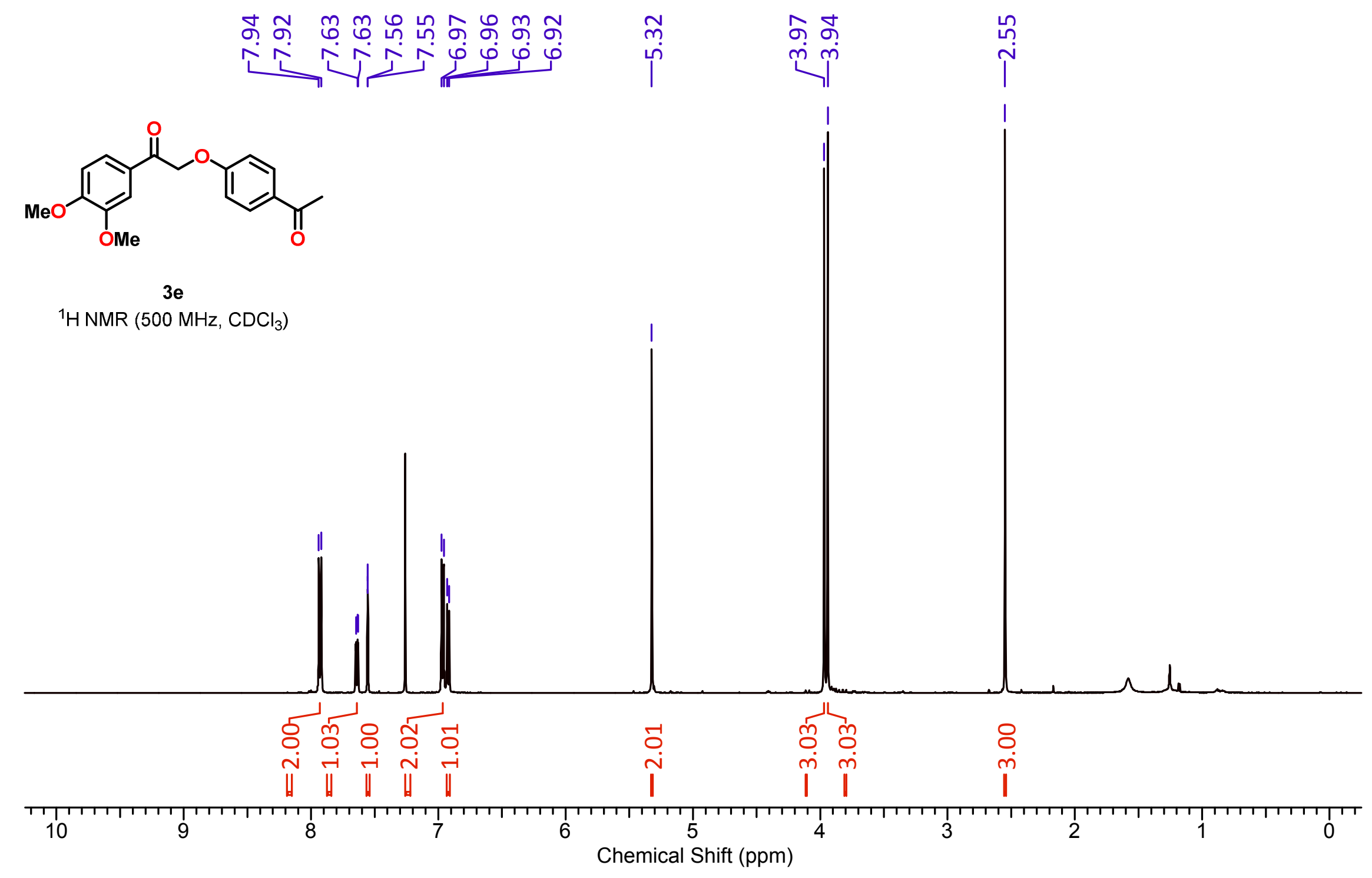




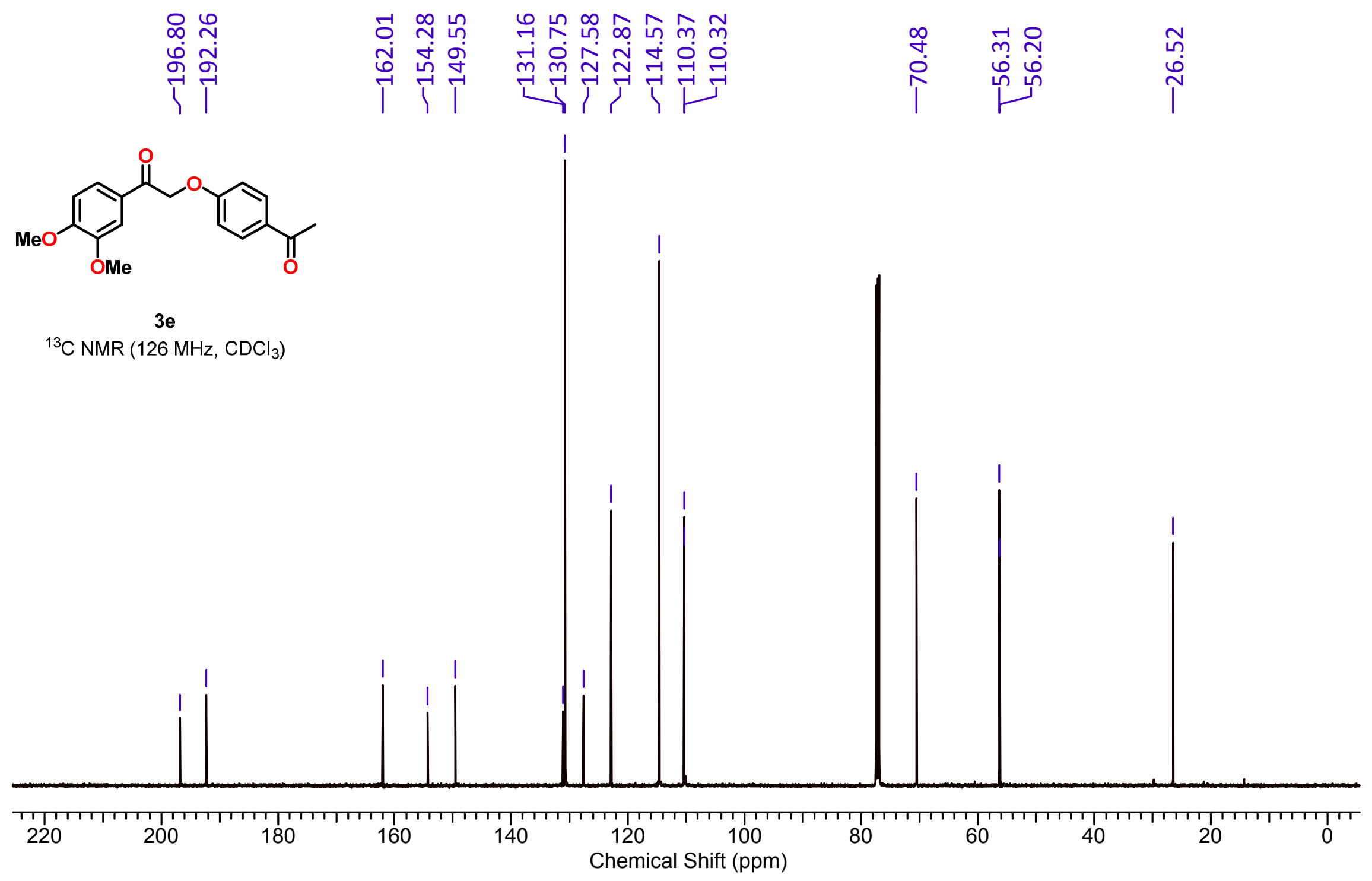


† 寸

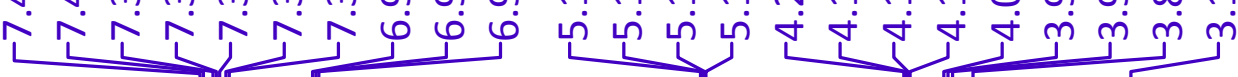
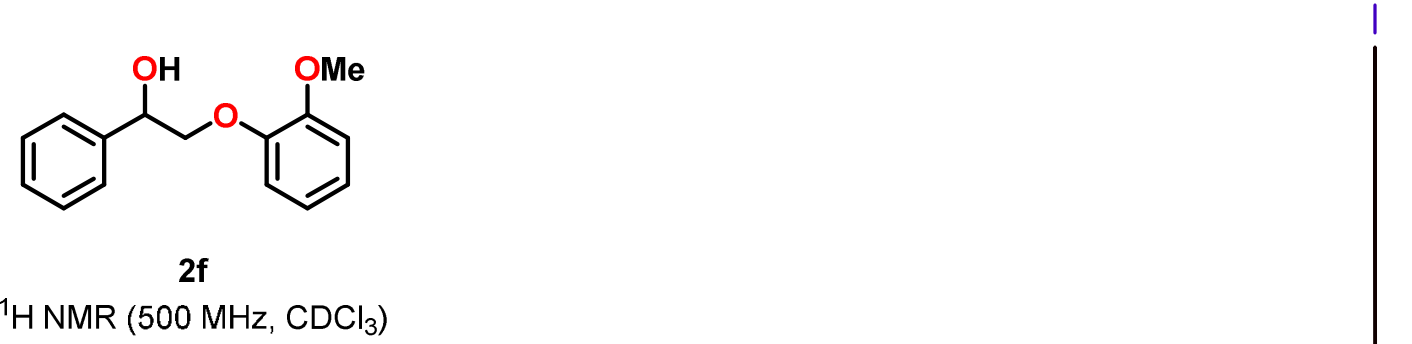

${ }^{1} \mathrm{HNMR}\left(500 \mathrm{MHz}, \mathrm{CDCl}_{3}\right)$

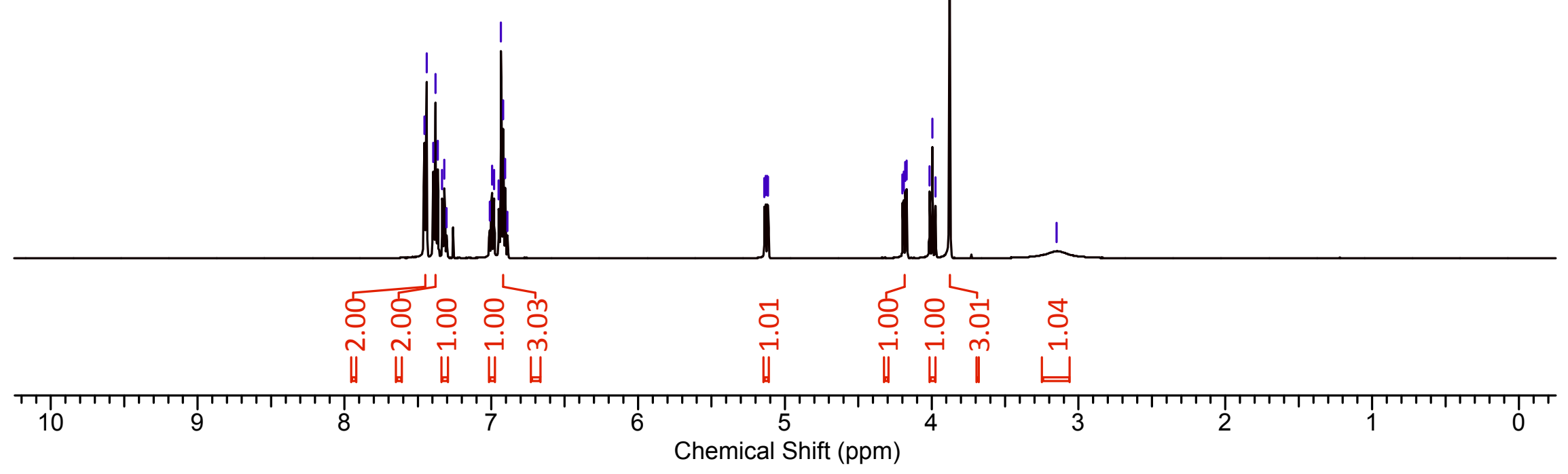



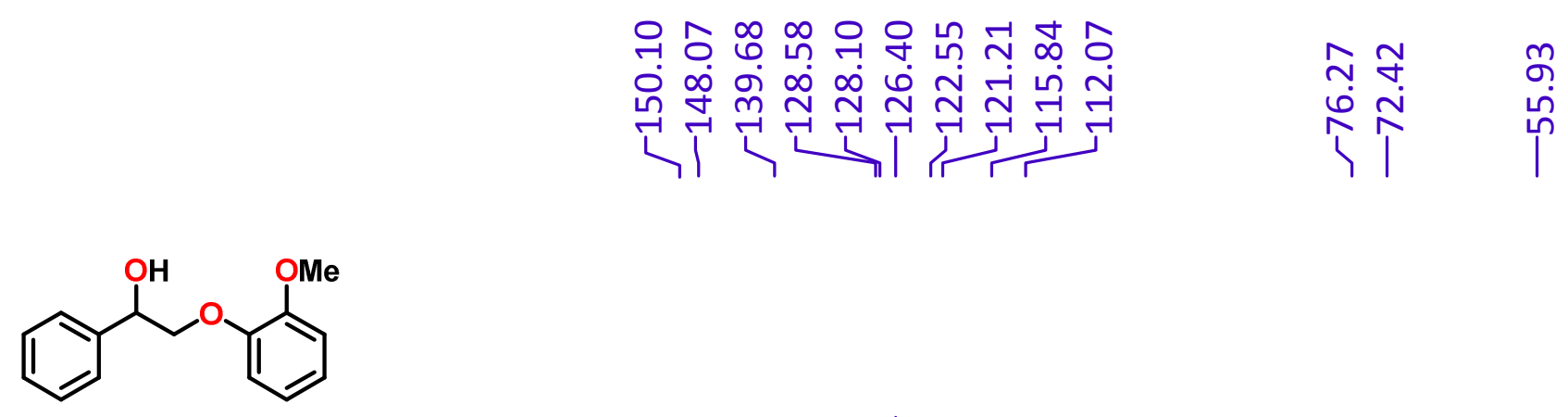

$2 f$

${ }^{13} \mathrm{C}$ NMR (126 MHz, $\mathrm{CDCl}_{3}$ )

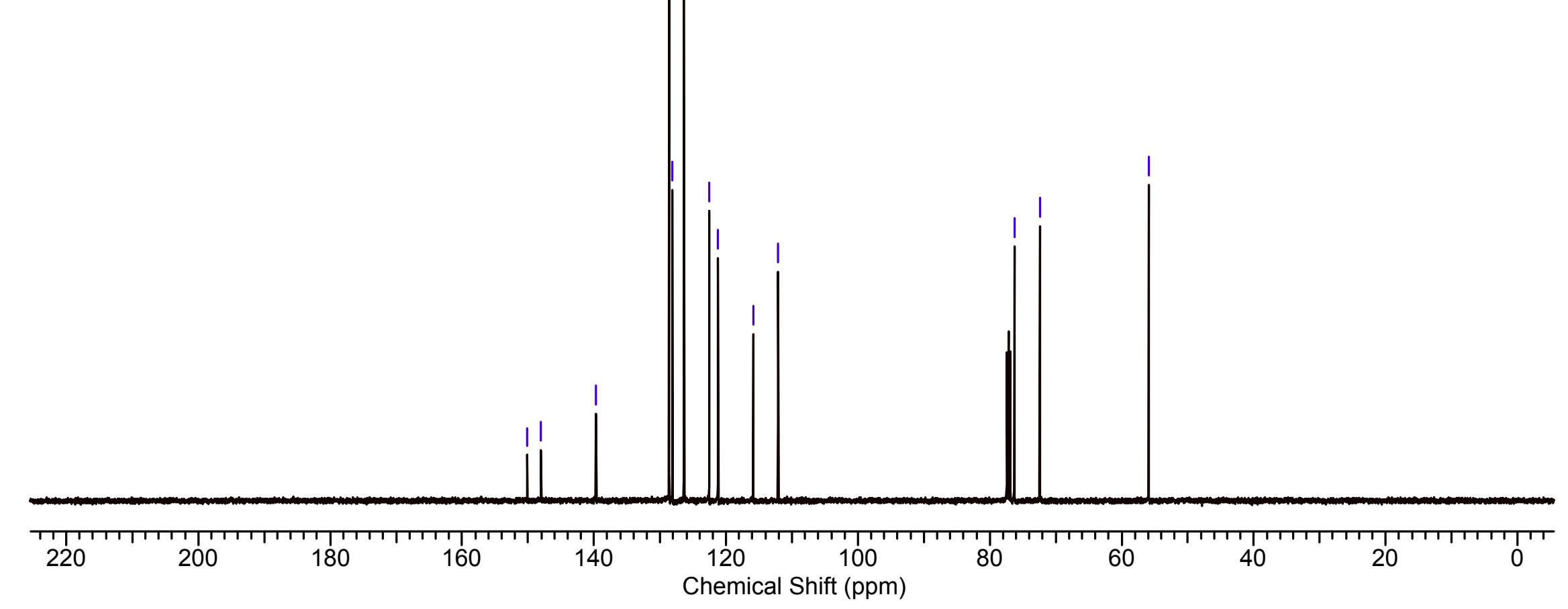




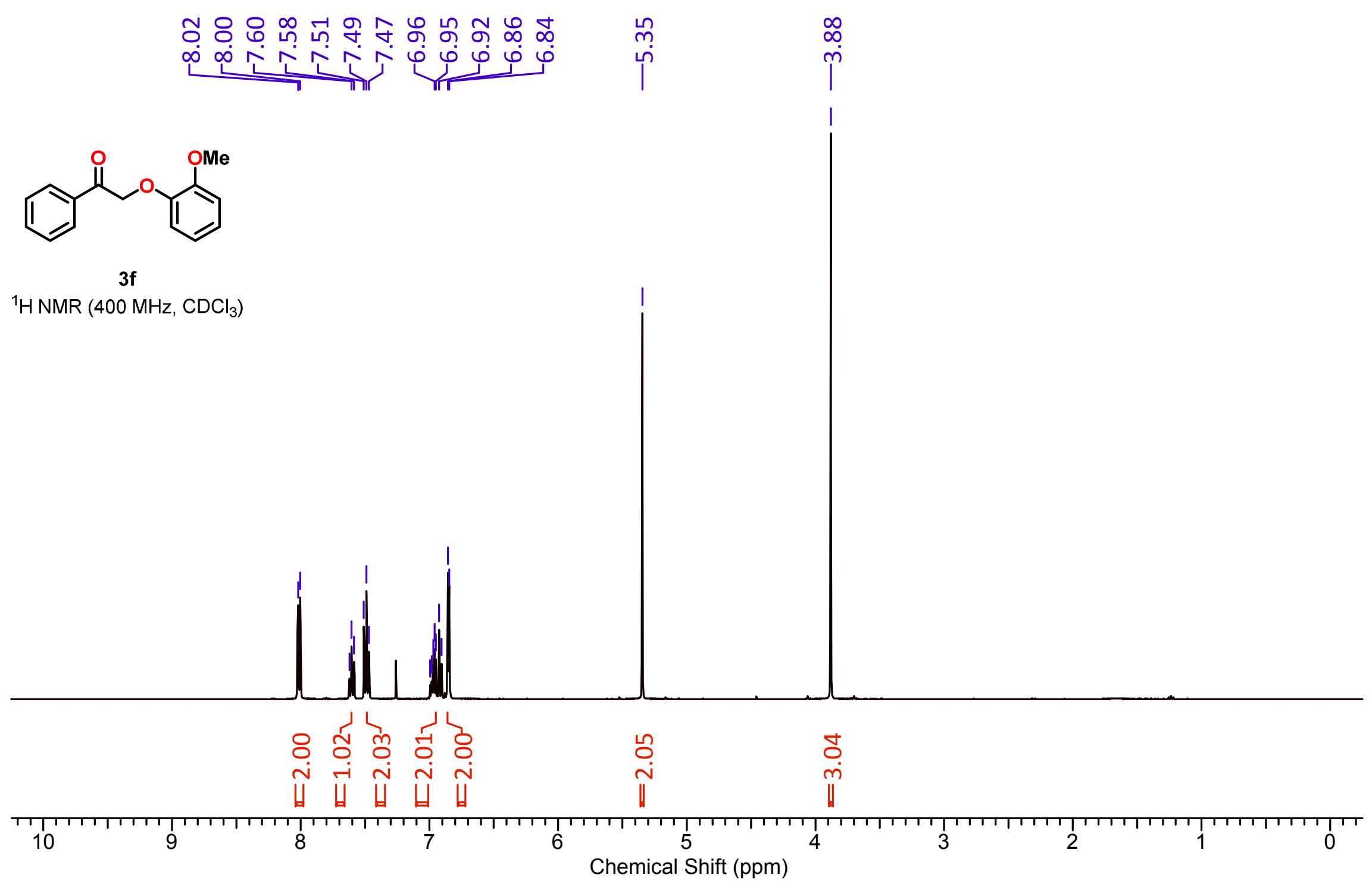




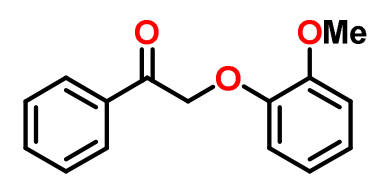

$3 f$

$\left.{ }^{13} \mathrm{C} \mathrm{NMR} \mathrm{(126} \mathrm{MHz,} \mathrm{CDCl}_{3}\right)$

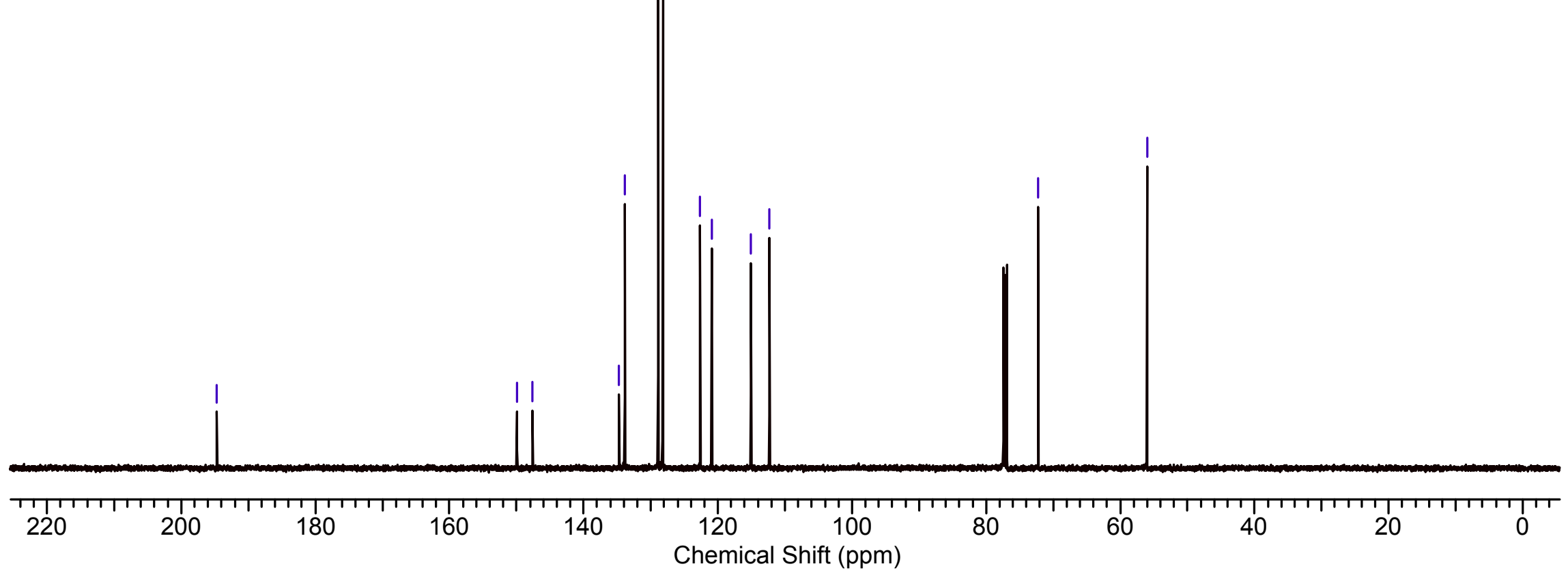




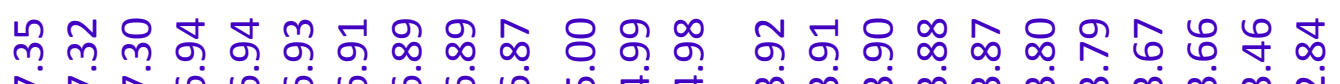

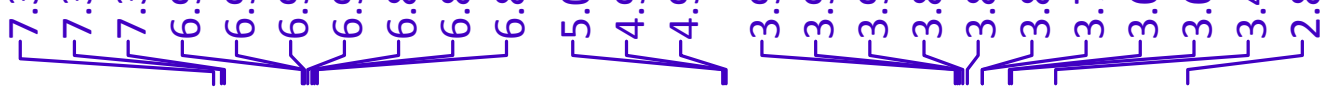

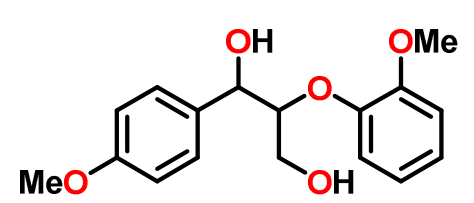

$4 a$

${ }^{1} \mathrm{H}$ NMR $\left(500 \mathrm{MHz}, \mathrm{CDCl}_{3}\right)$

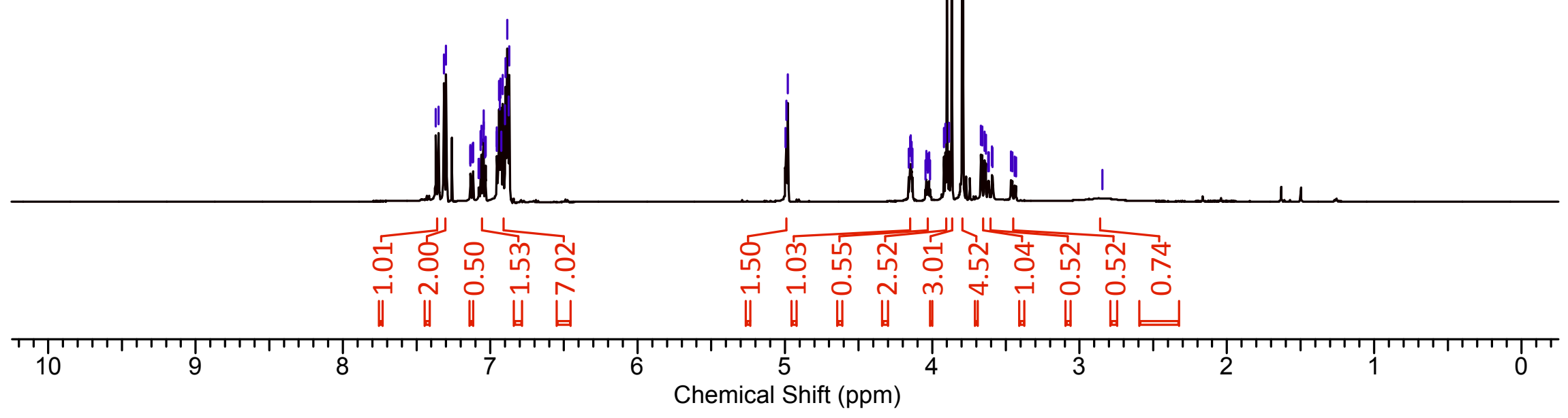




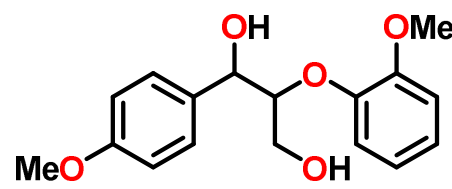

$4 a$

${ }^{13} \mathrm{C} \mathrm{NMR}\left(126 \mathrm{MHz}, \mathrm{CDCl}_{3}\right)$

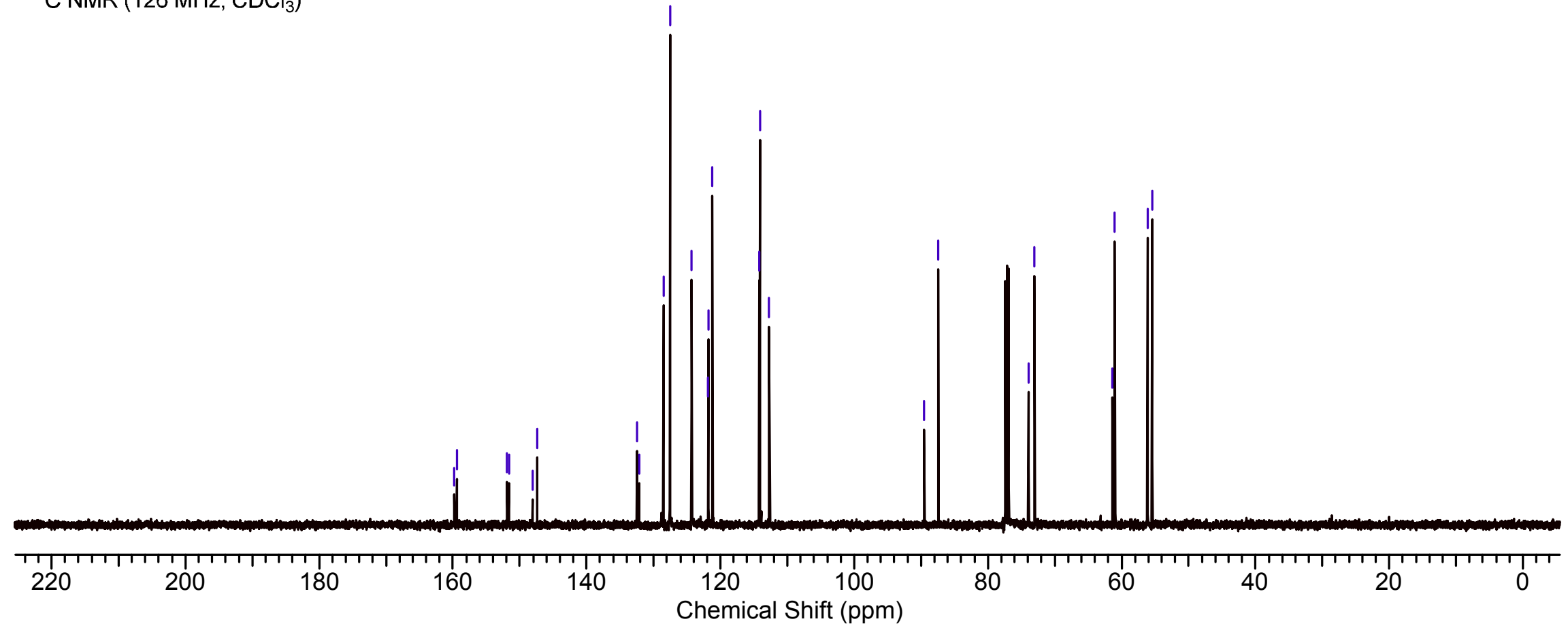




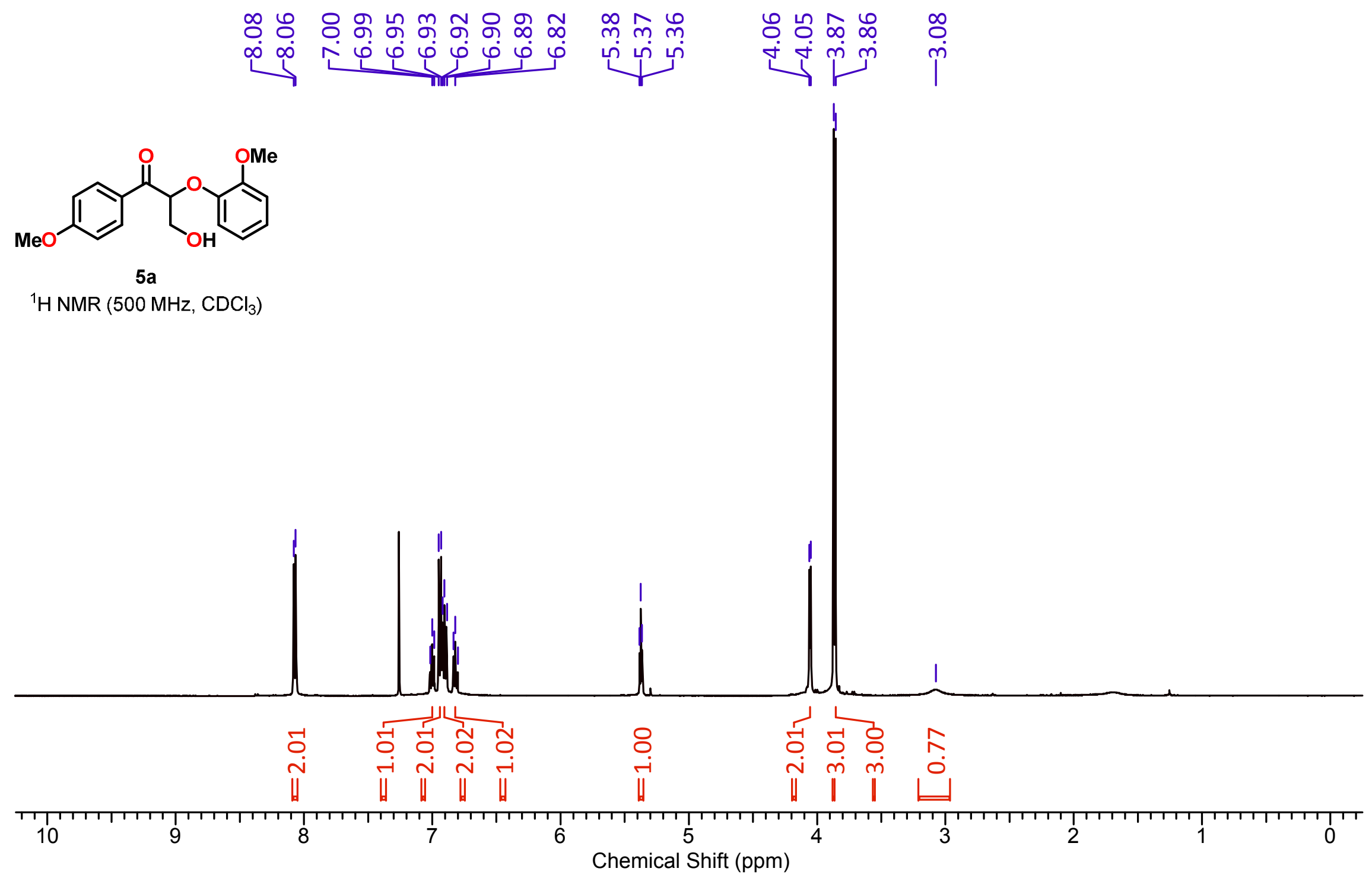



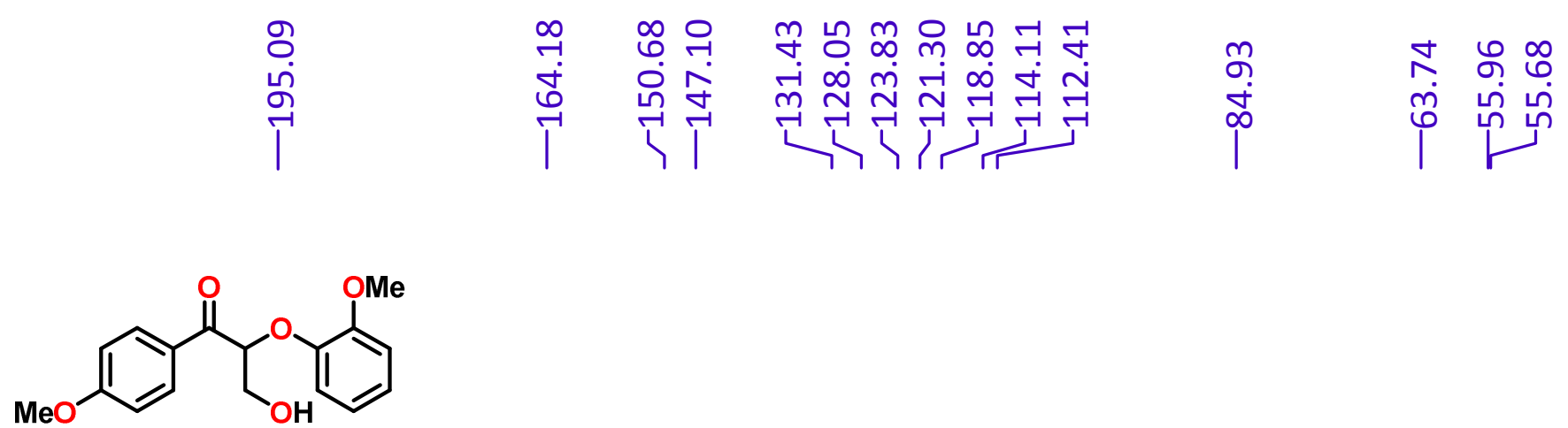

$5 a$

${ }^{13} \mathrm{C}$ NMR $\left(126 \mathrm{MHz}, \mathrm{CDCl}_{3}\right)$

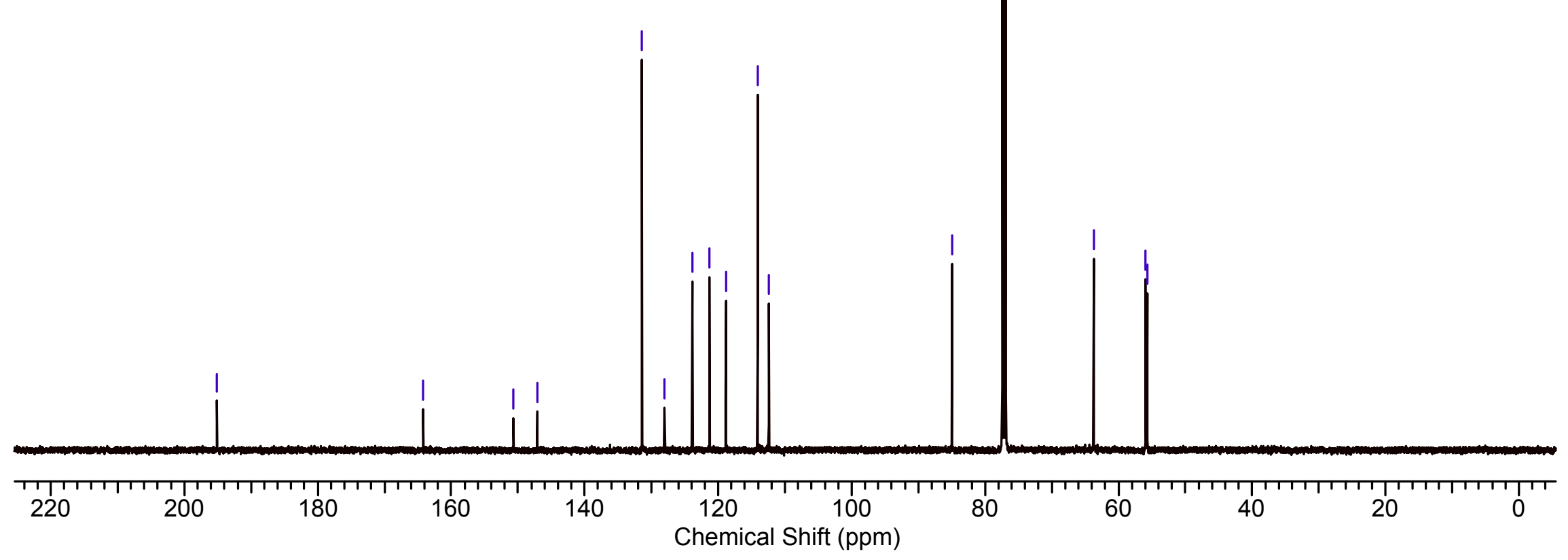




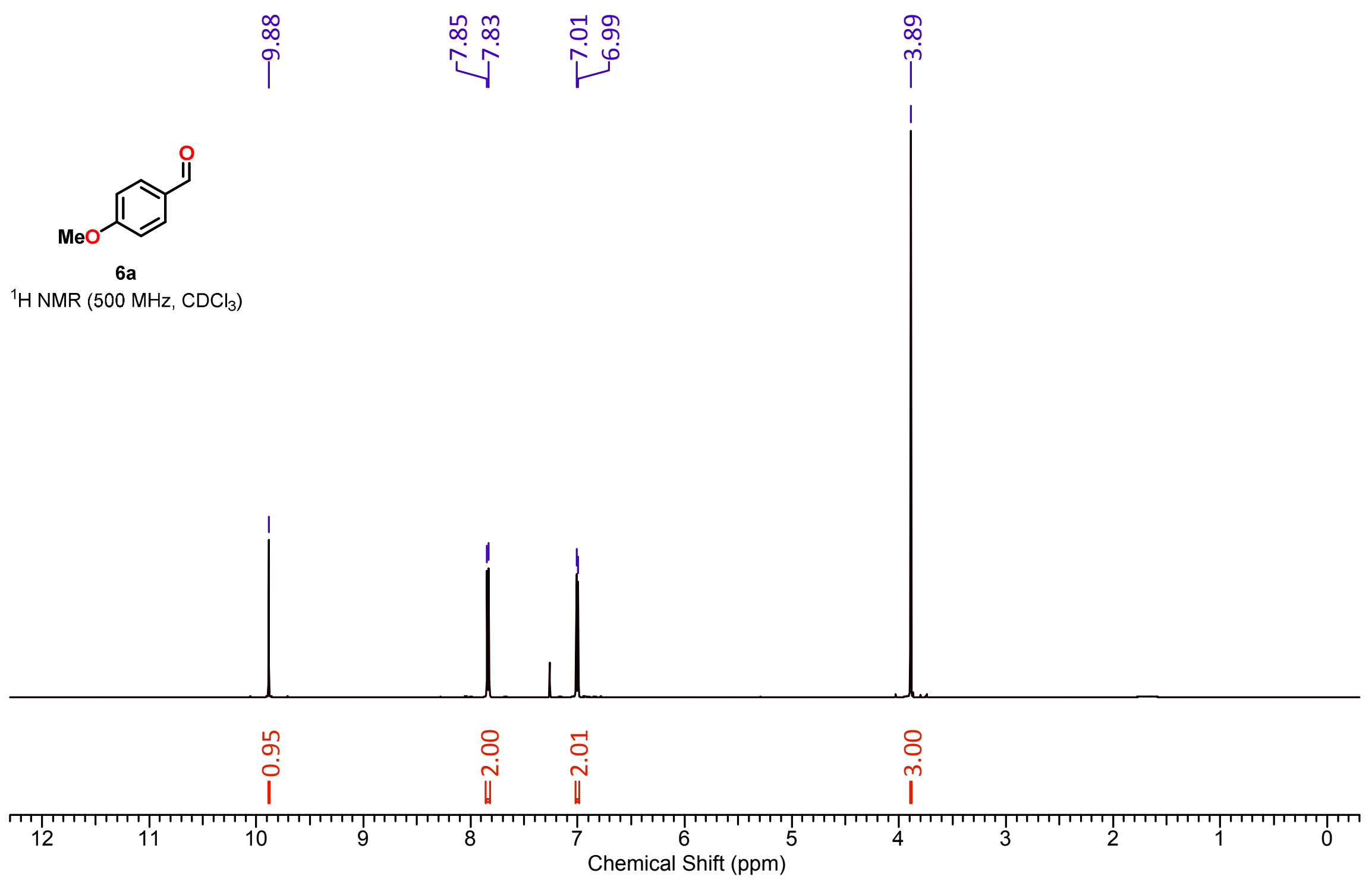



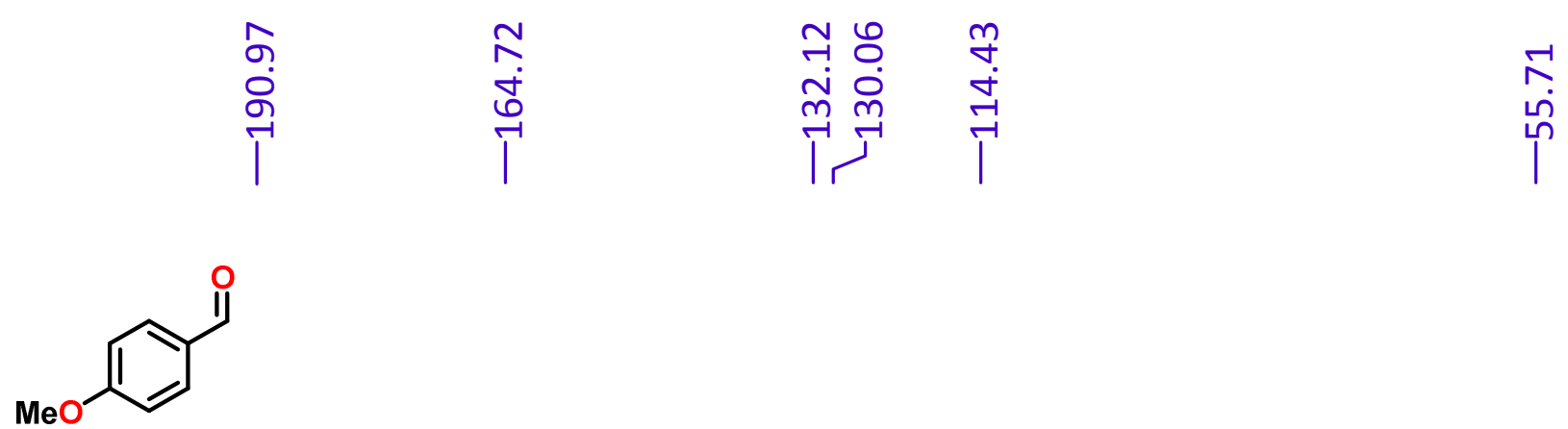

$6 a$

$\left.{ }^{13} \mathrm{C} \mathrm{NMR} \mathrm{(126} \mathrm{MHz,} \mathrm{CDCl}_{3}\right)$

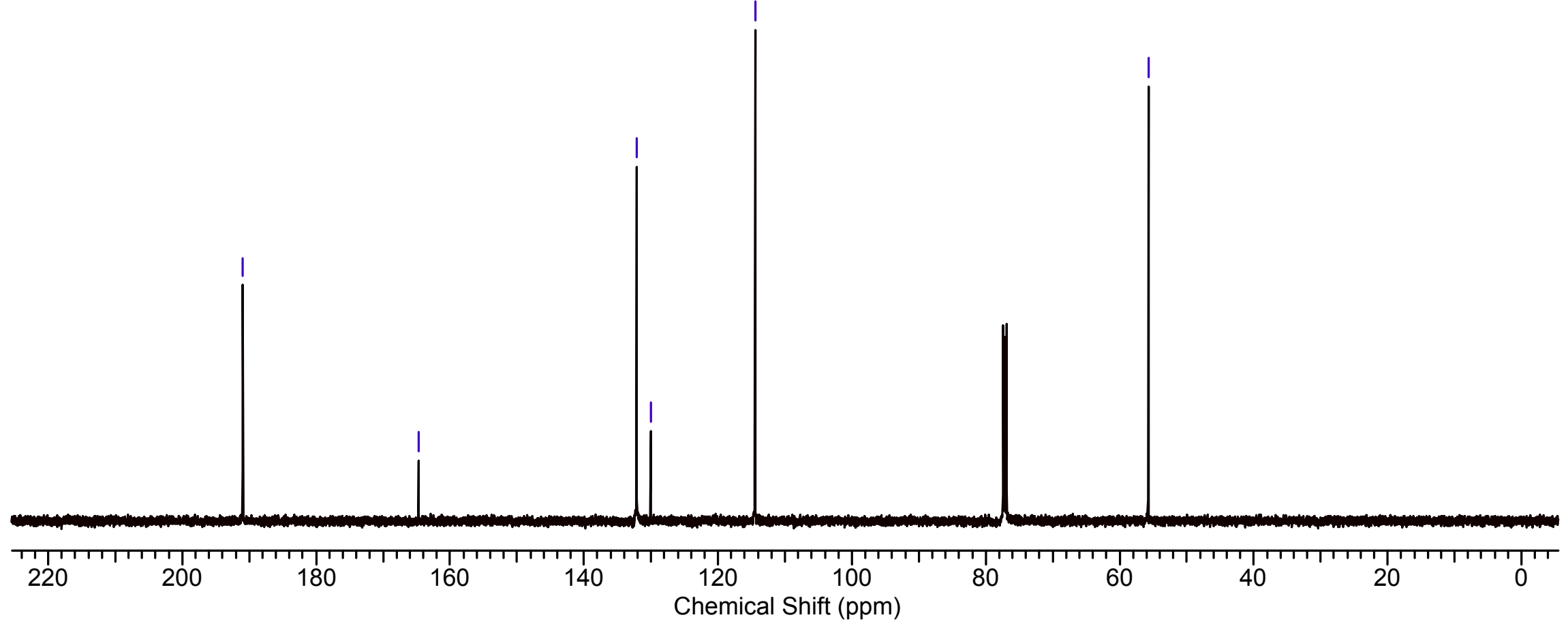




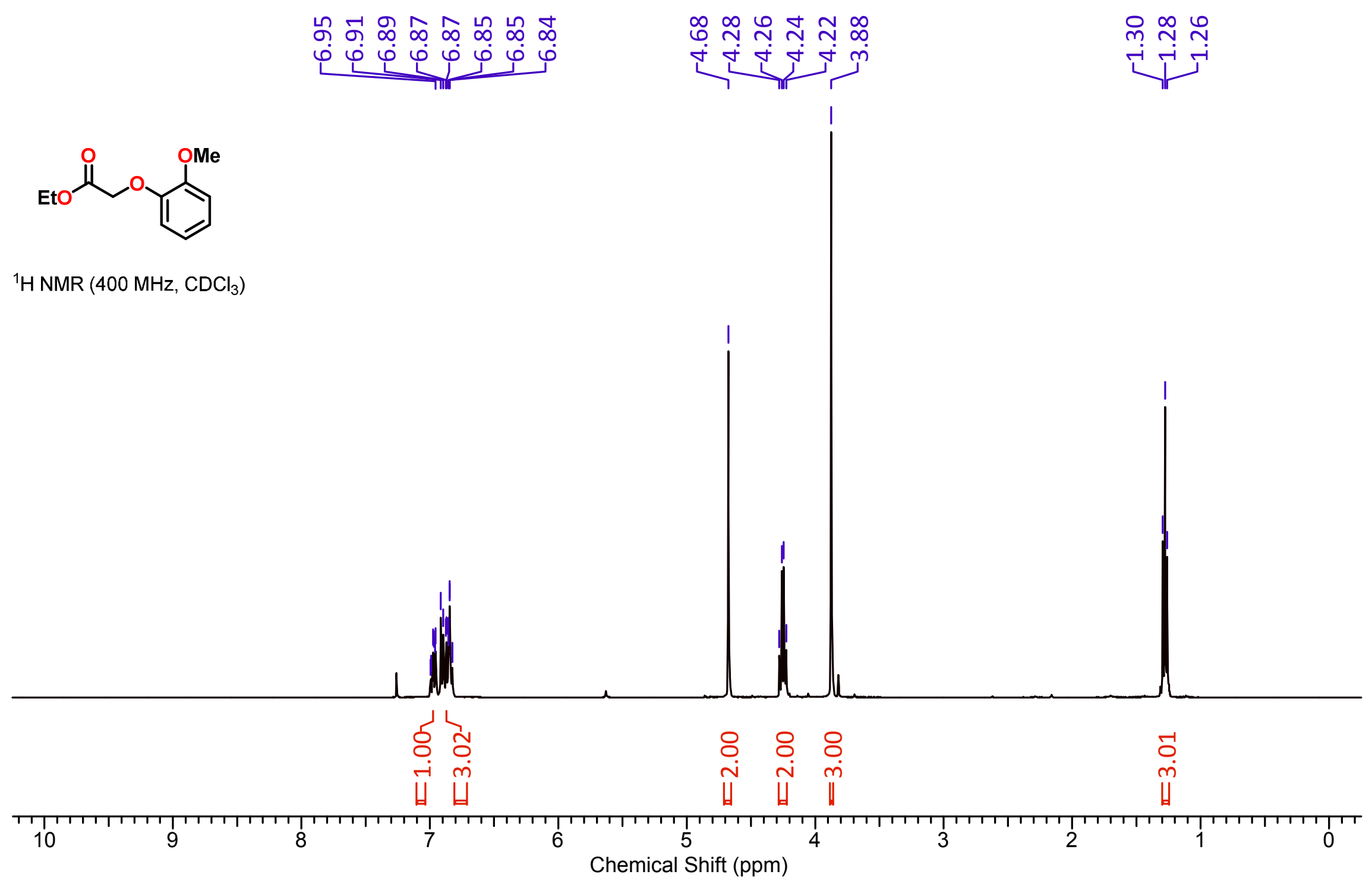




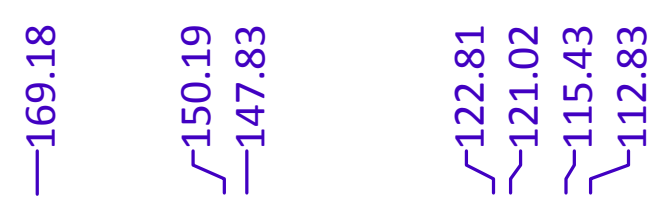

ำ

ธิ่

$\stackrel{\stackrel{n}{*}}{\stackrel{+}{i}}$

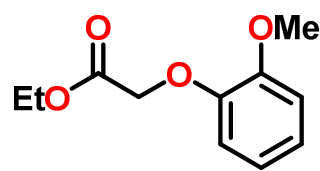

${ }^{13} \mathrm{C} \mathrm{NMR}\left(126 \mathrm{MHz}, \mathrm{CDCl}_{3}\right)$

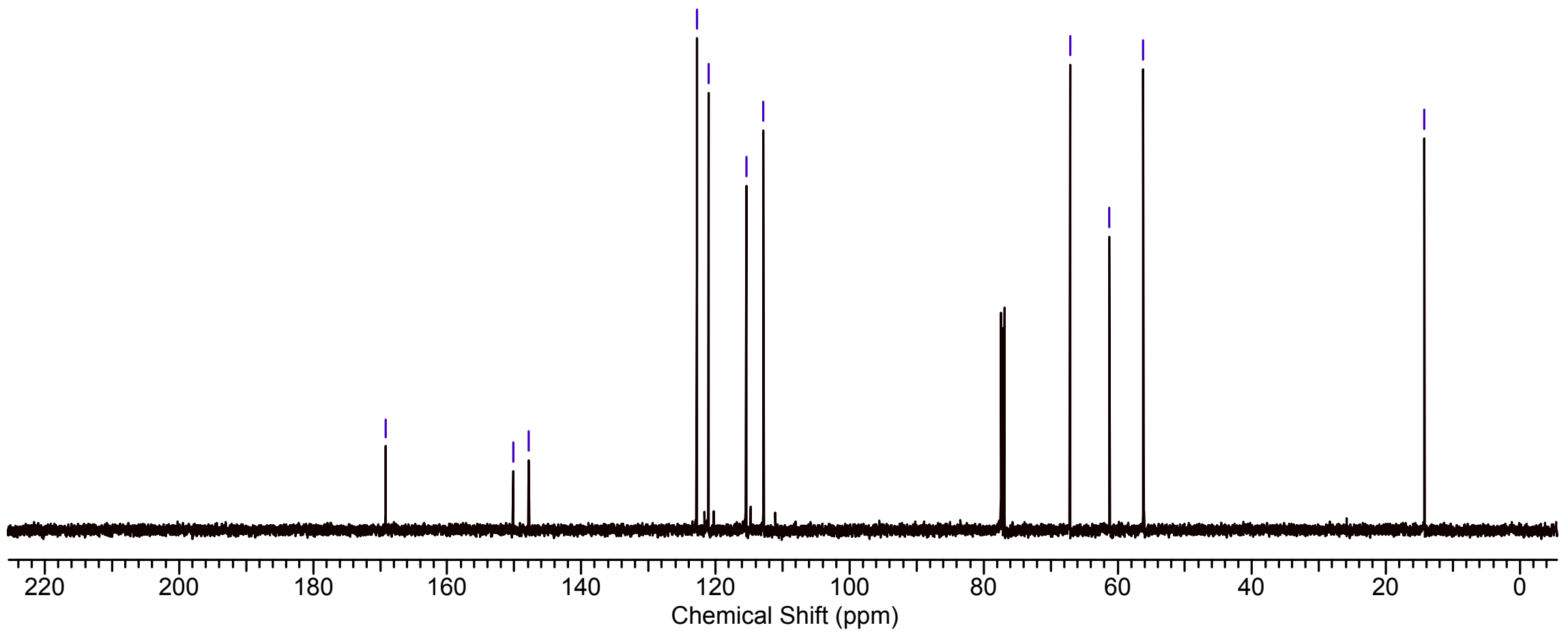




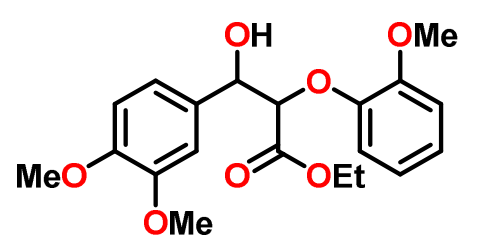

${ }^{1} \mathrm{H} \mathrm{NMR}\left(500 \mathrm{MHz}, \mathrm{CDCl}_{3}\right)$

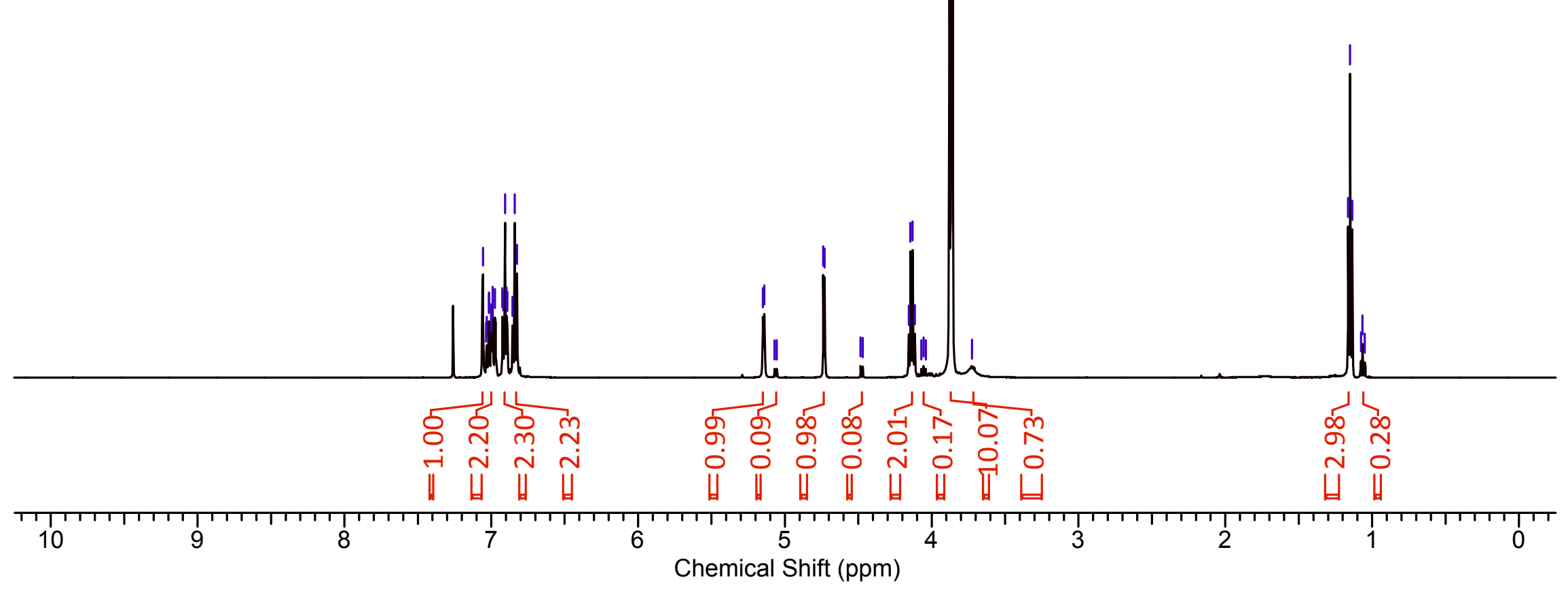




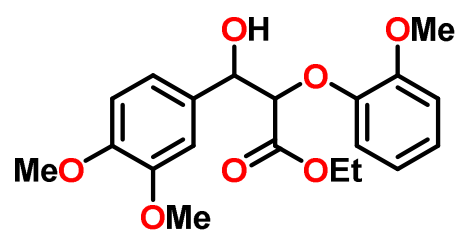

$\left.{ }^{13} \mathrm{C} \mathrm{NMR} \mathrm{(126} \mathrm{MHz,} \mathrm{CDCl}_{3}\right)$

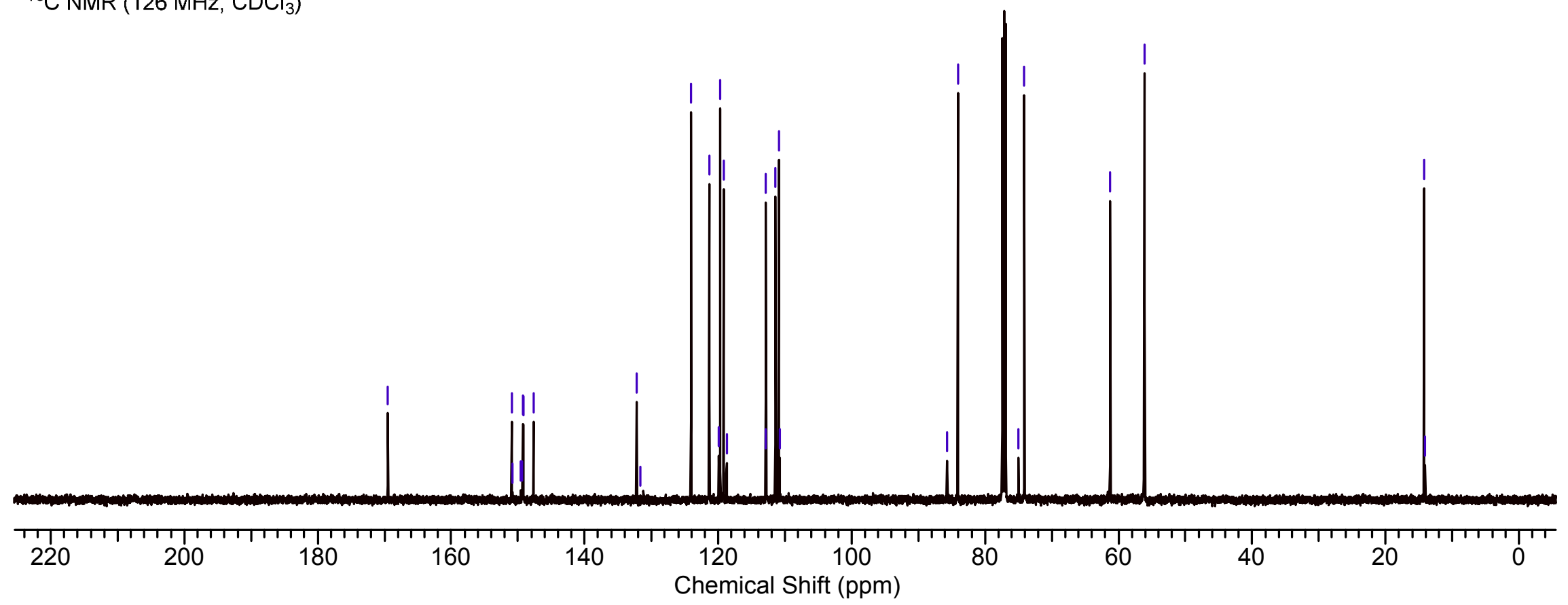


பு

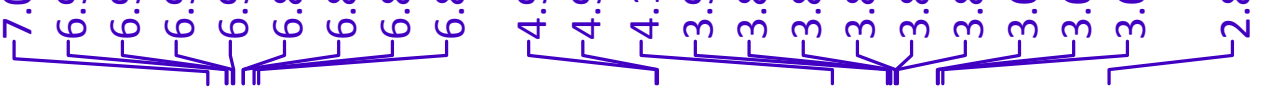

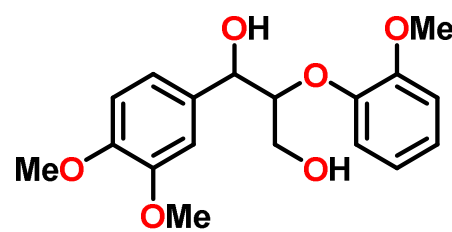

4b

${ }^{1} \mathrm{H} \mathrm{NMR}\left(500 \mathrm{MHz}, \mathrm{CDCl}_{3}\right)$
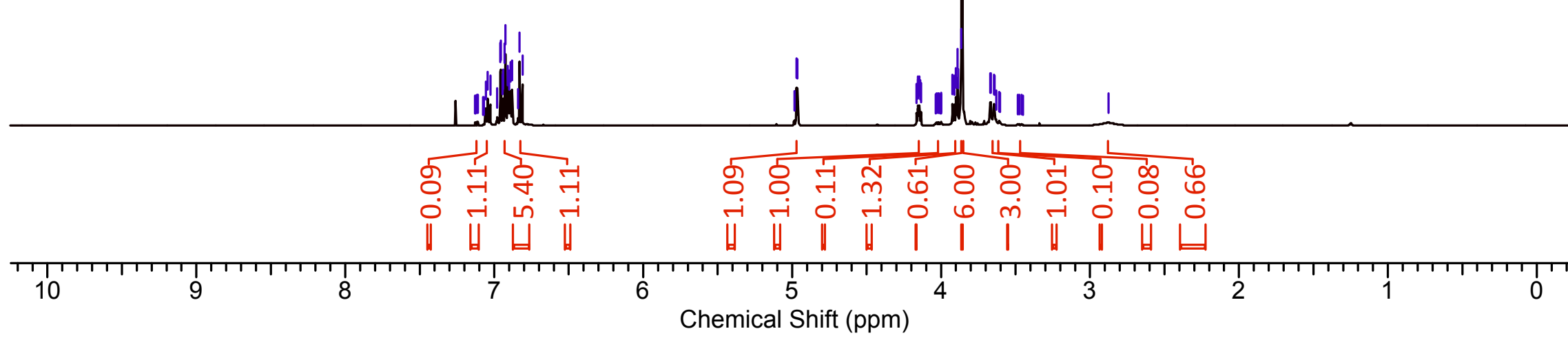


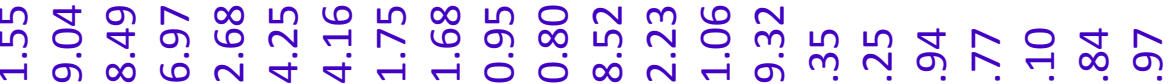

는 곤

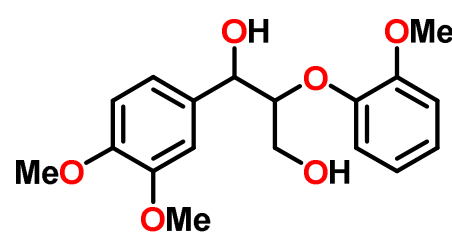

4b

${ }^{13} \mathrm{C} \mathrm{NMR}\left(126 \mathrm{MHz}, \mathrm{CDCl}_{3}\right)$

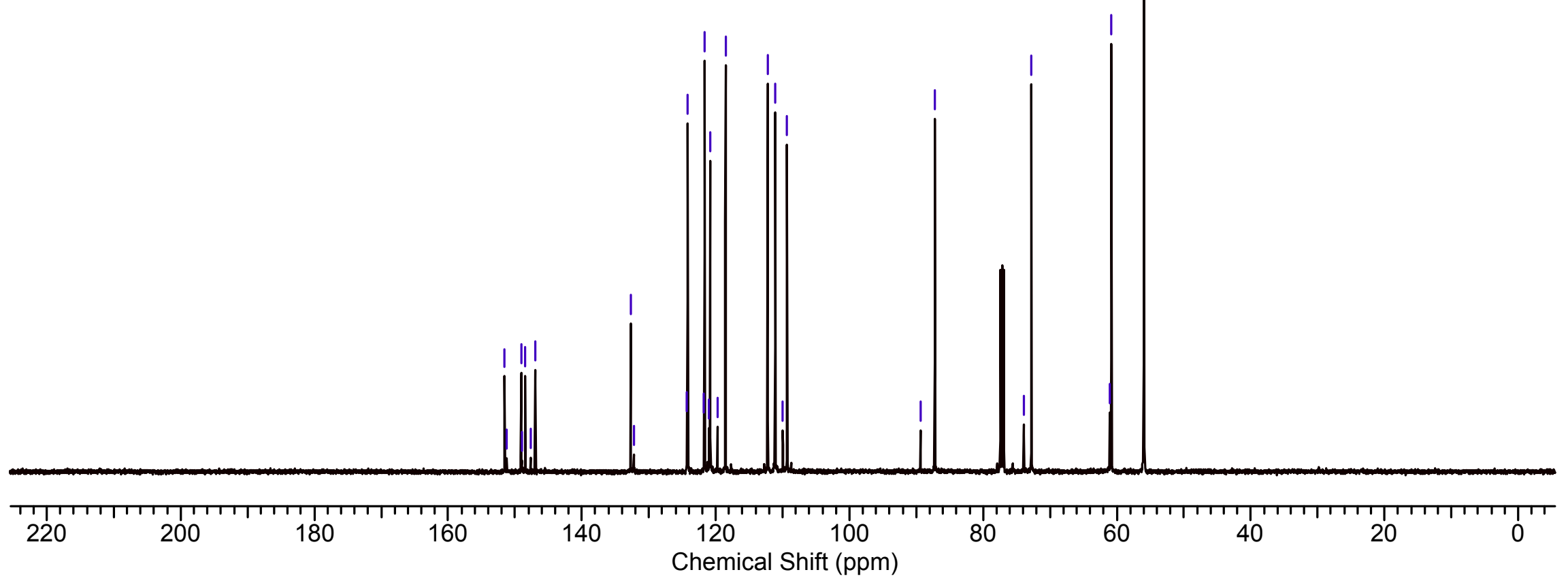




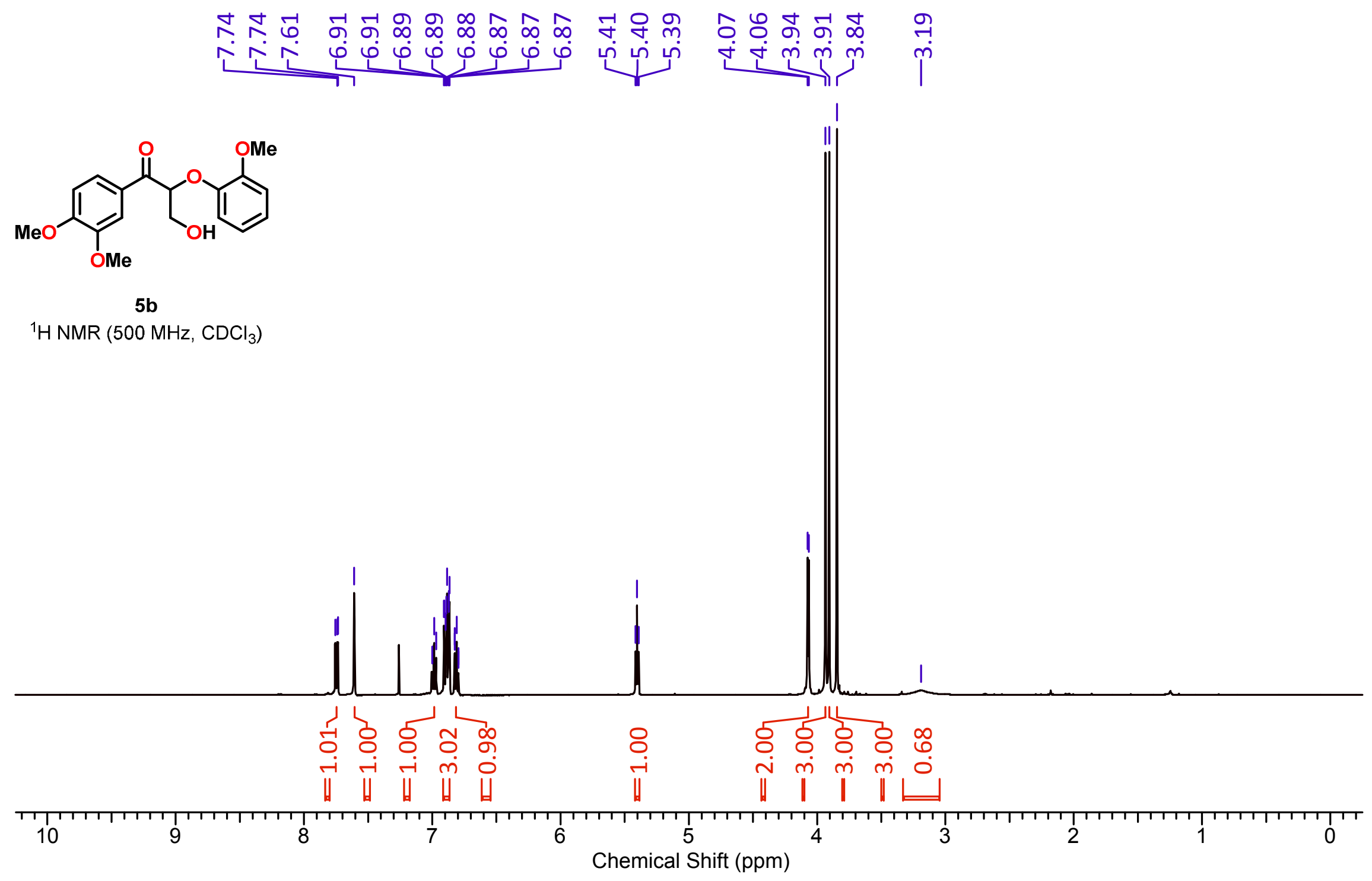


ำ ำ

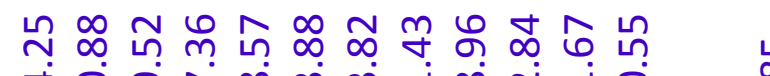

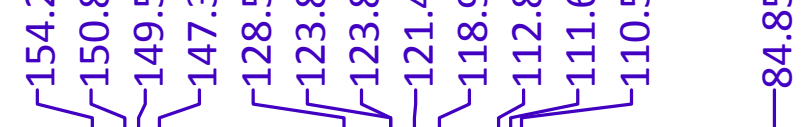

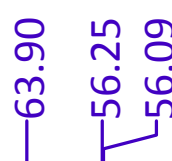

OMe

$5 b$

$\left.{ }^{13} \mathrm{C} \mathrm{NMR} \mathrm{(126} \mathrm{MHz,} \mathrm{CDCl}_{3}\right)$

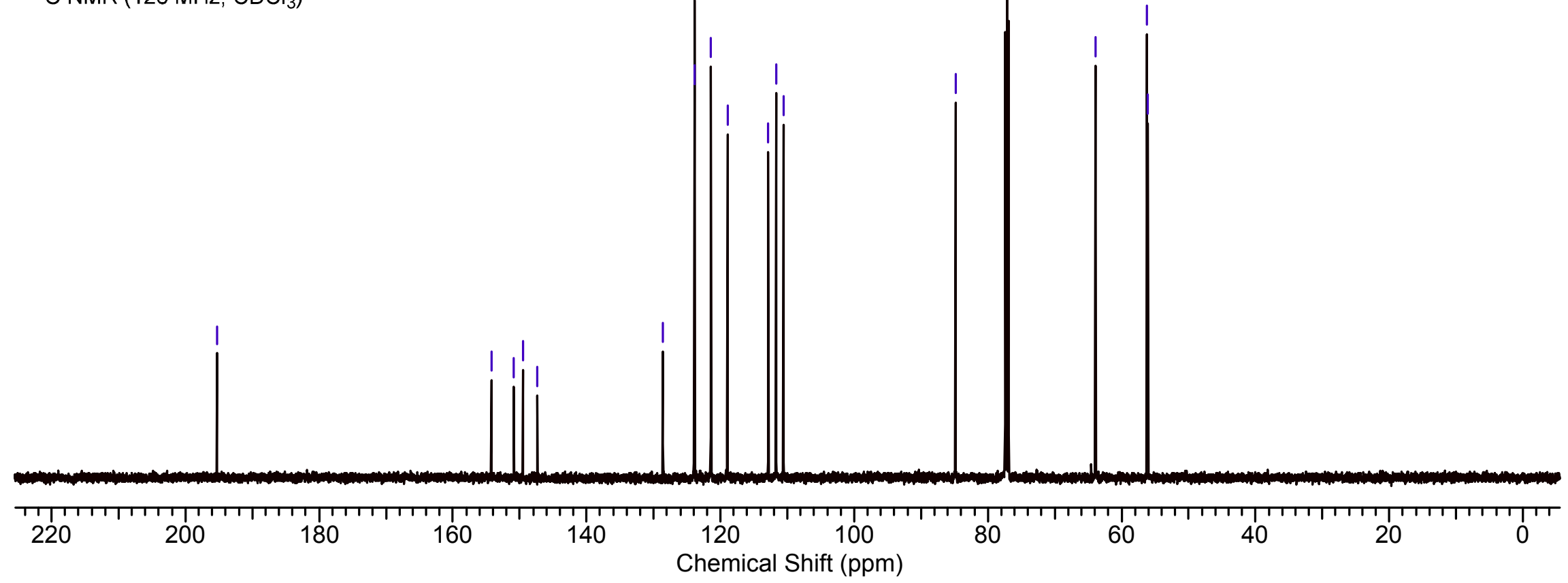




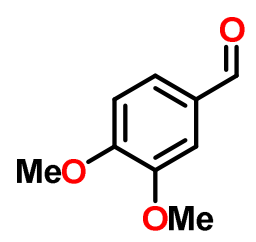

6b

${ }^{1} \mathrm{H} \mathrm{NMR}\left(500 \mathrm{MHz}, \mathrm{CDCl}_{3}\right)$

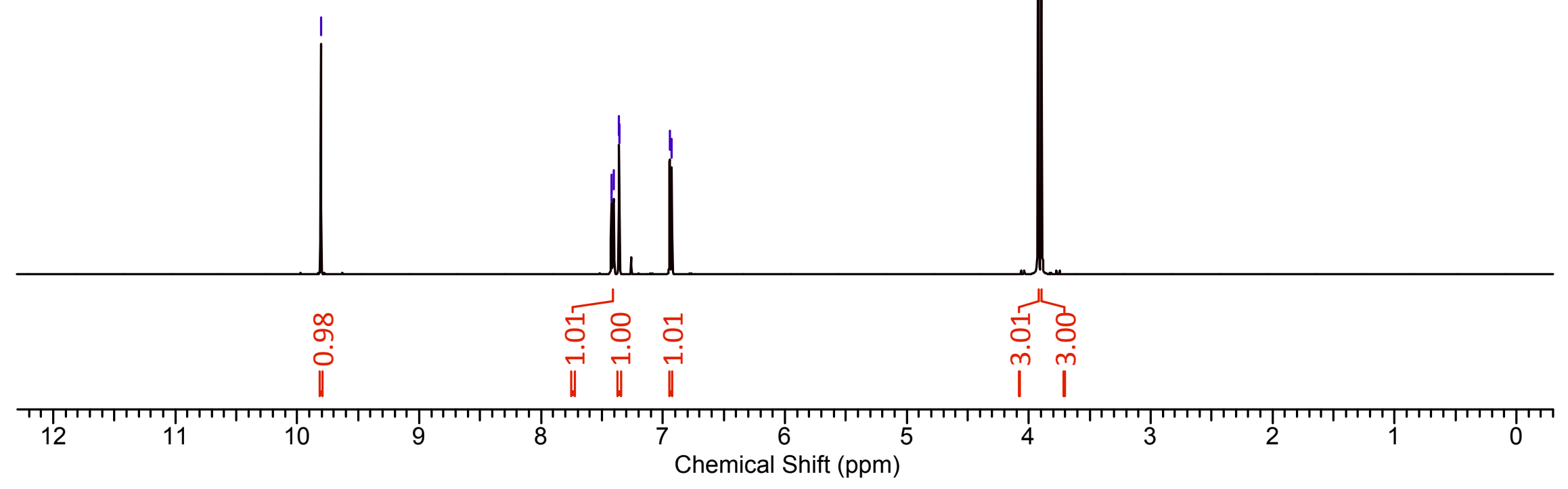




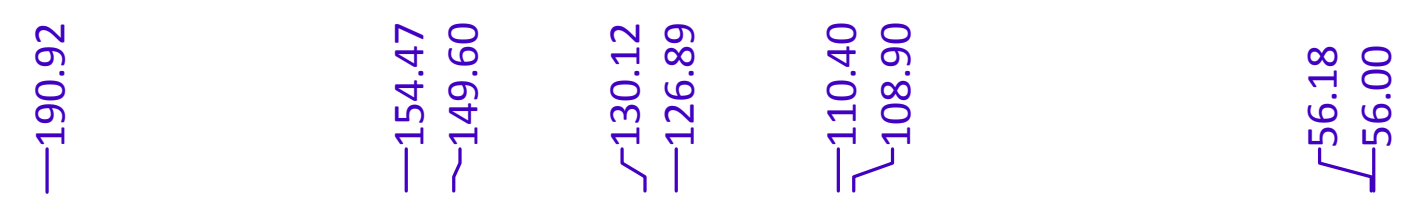

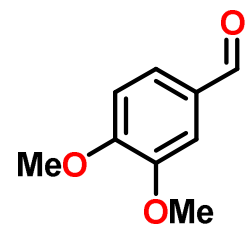

$6 \mathrm{~b}$

${ }^{13} \mathrm{C} \mathrm{NMR}\left(126 \mathrm{MHz}, \mathrm{CDCl}_{3}\right.$ )

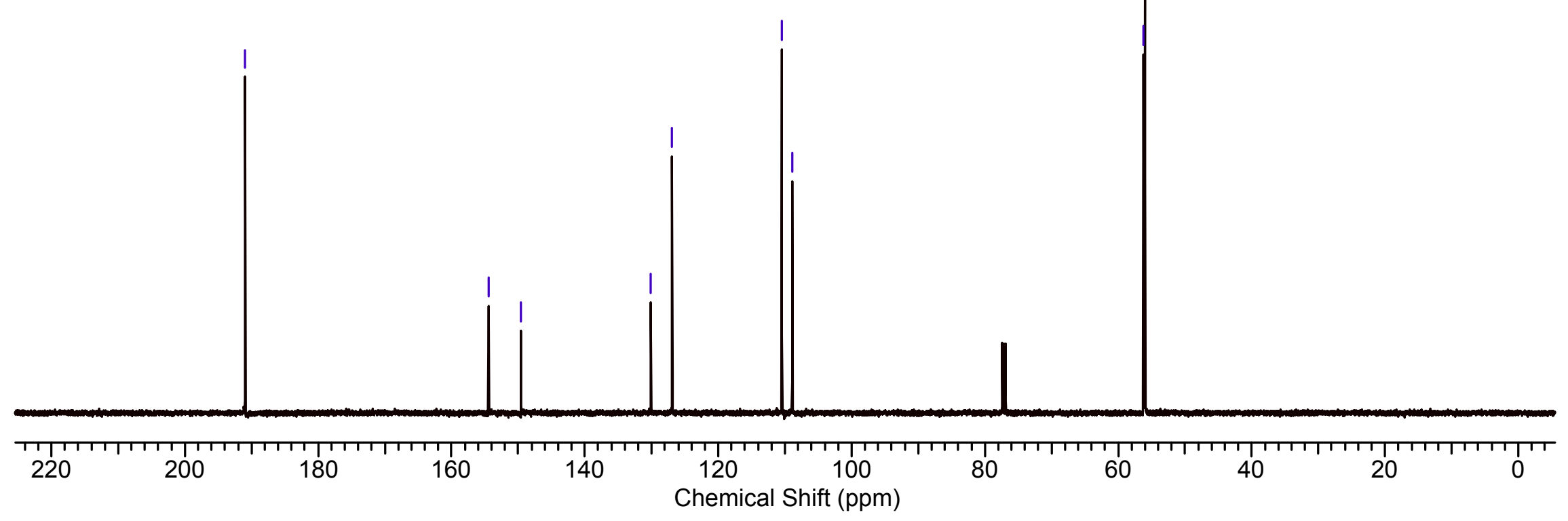




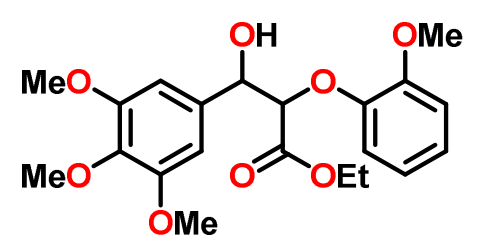

${ }^{1} \mathrm{H} \mathrm{NMR}\left(500 \mathrm{MHz}, \mathrm{CDCl}_{3}\right)$

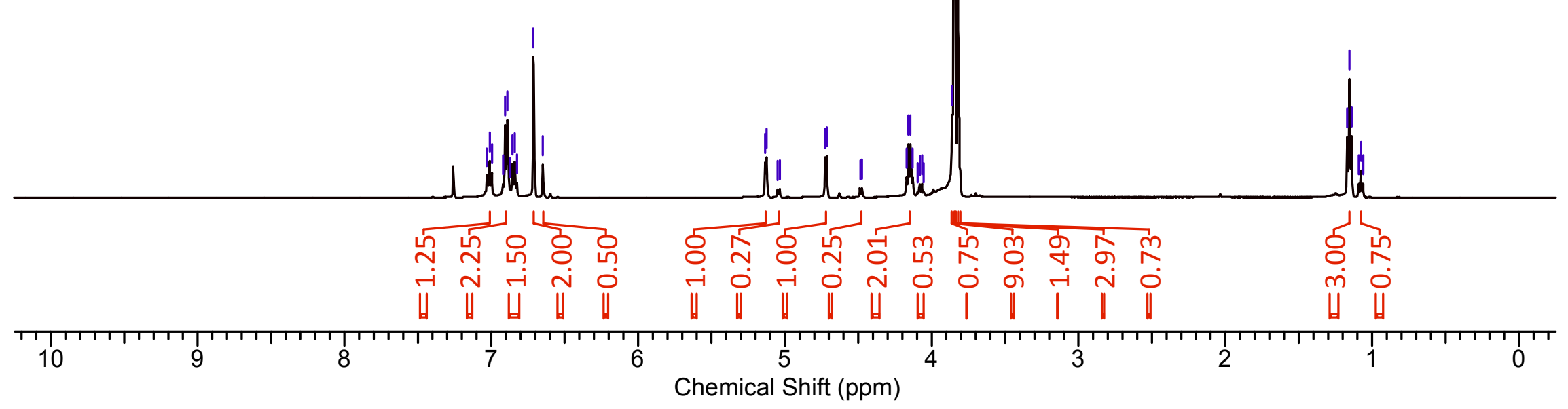




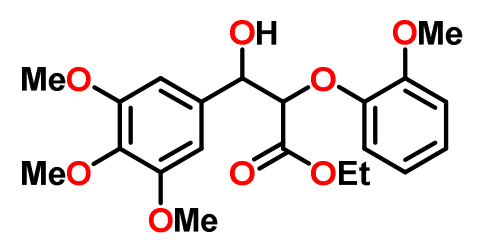

$\left.{ }^{13} \mathrm{C} \mathrm{NMR} \mathrm{(126} \mathrm{MHz,} \mathrm{CDCl}_{3}\right)$

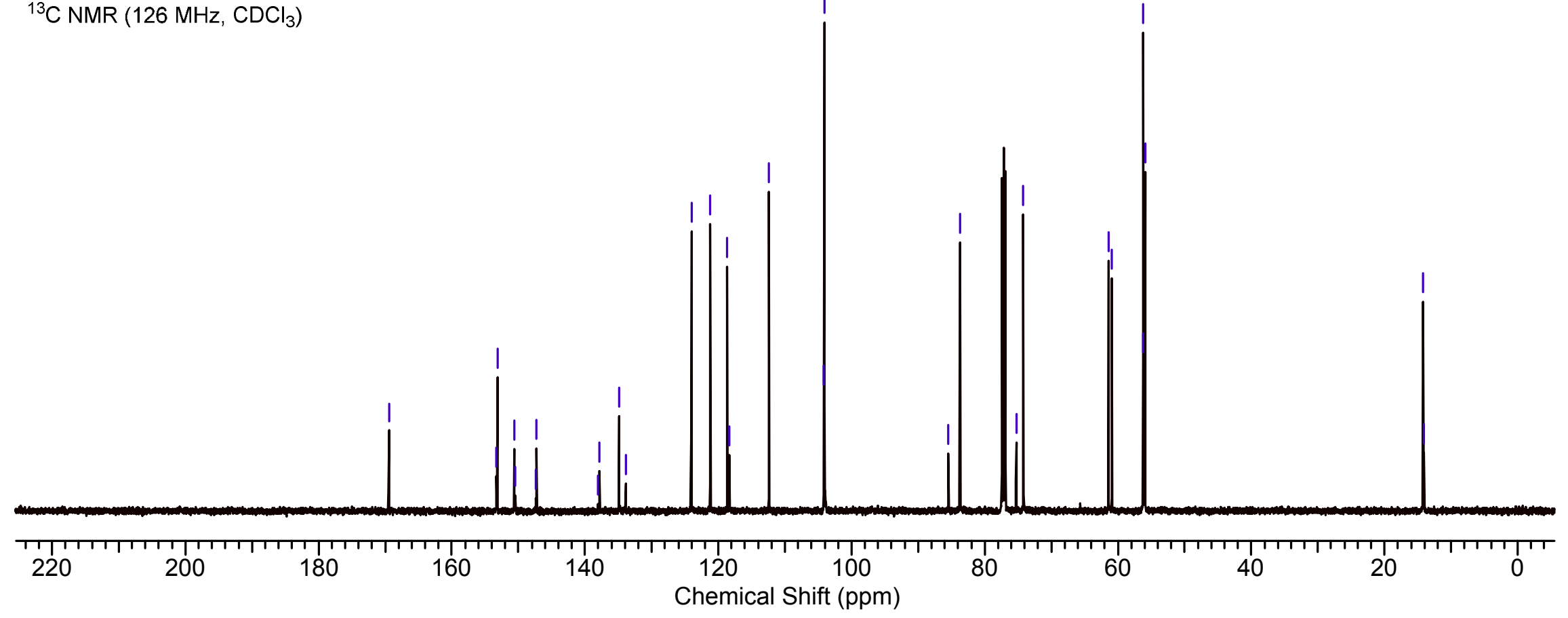




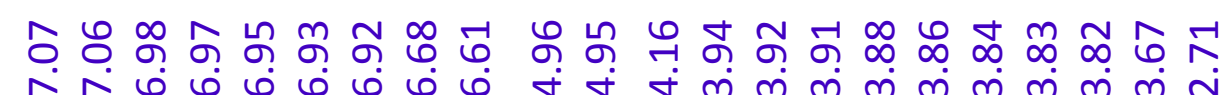

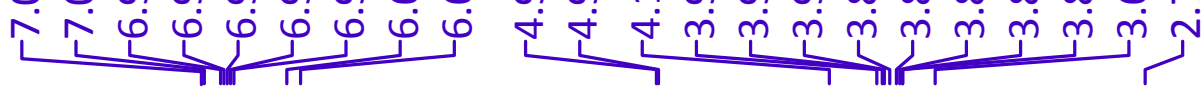

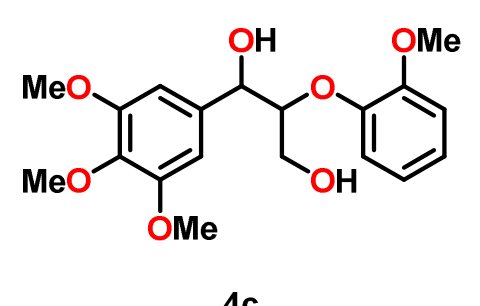

${ }^{1} \mathrm{H} \mathrm{NMR}\left(500 \mathrm{MHz}, \mathrm{CDCl}_{3}\right)$

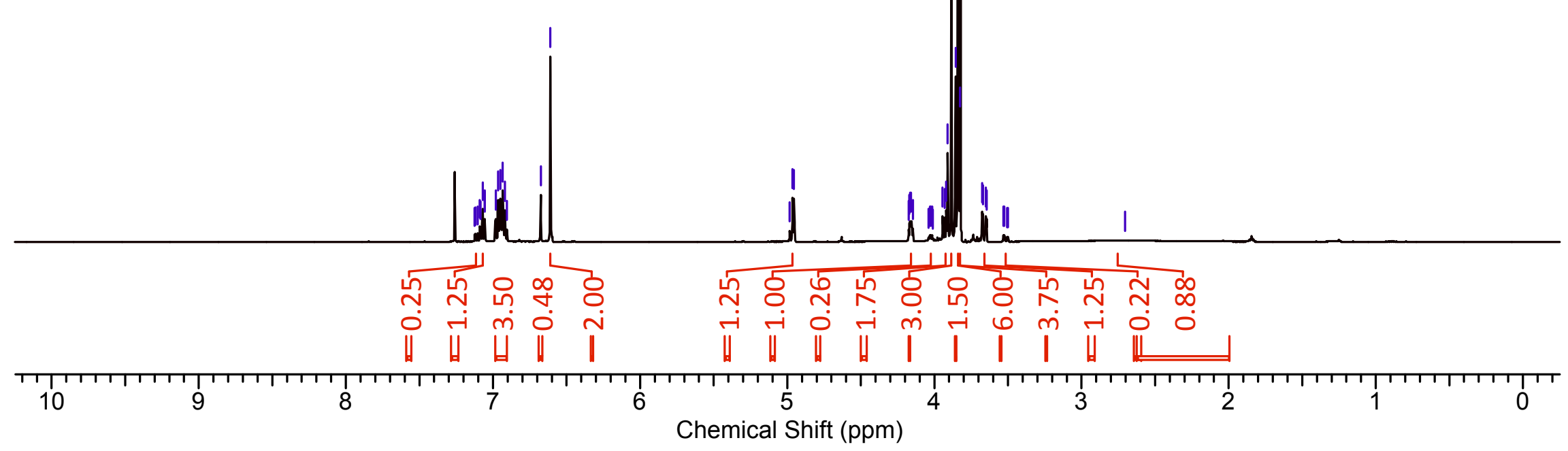



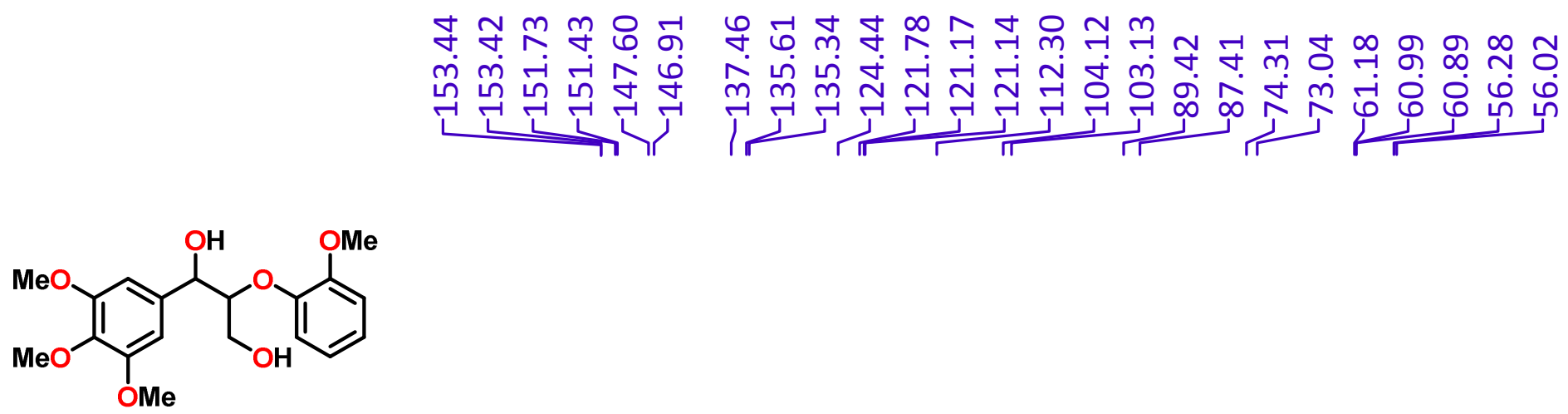

4c

${ }^{13} \mathrm{C}$ NMR (126 MHz, $\left.\mathrm{CDCl}_{3}\right)$

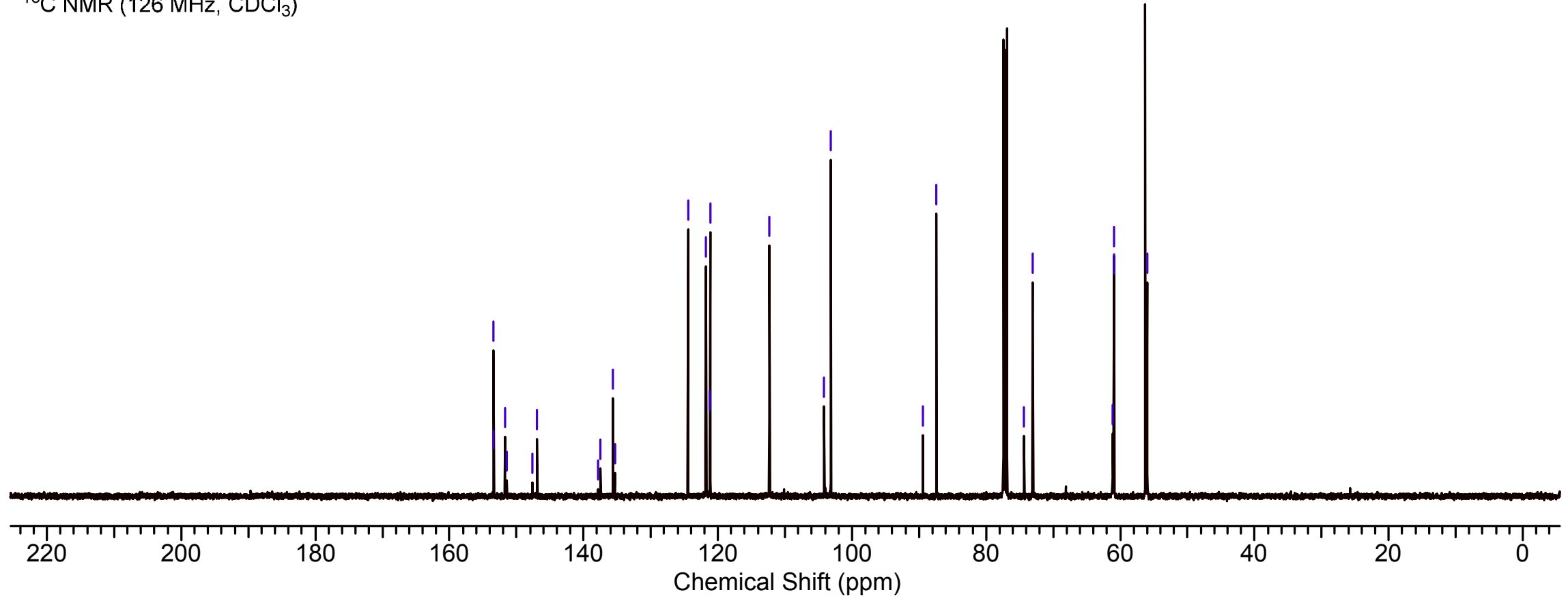




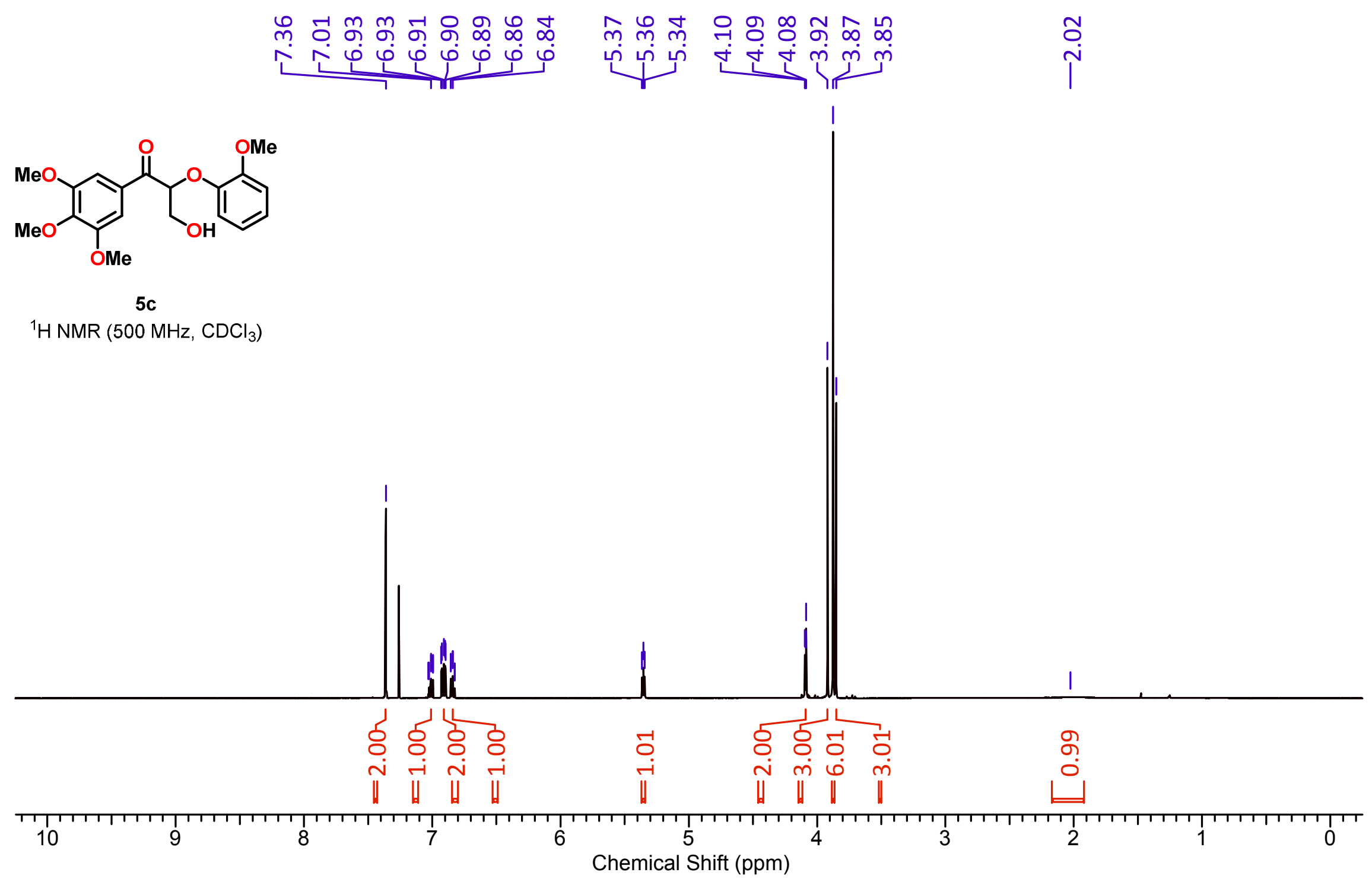




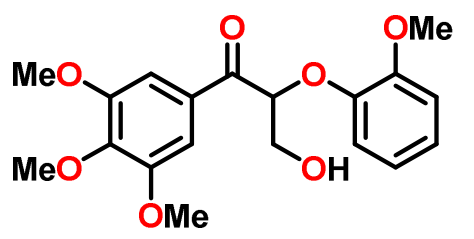

$5 \mathrm{c}$

$\left.{ }^{13} \mathrm{C} \mathrm{NMR} \mathrm{(126} \mathrm{MHz,} \mathrm{CDCl}_{3}\right)$

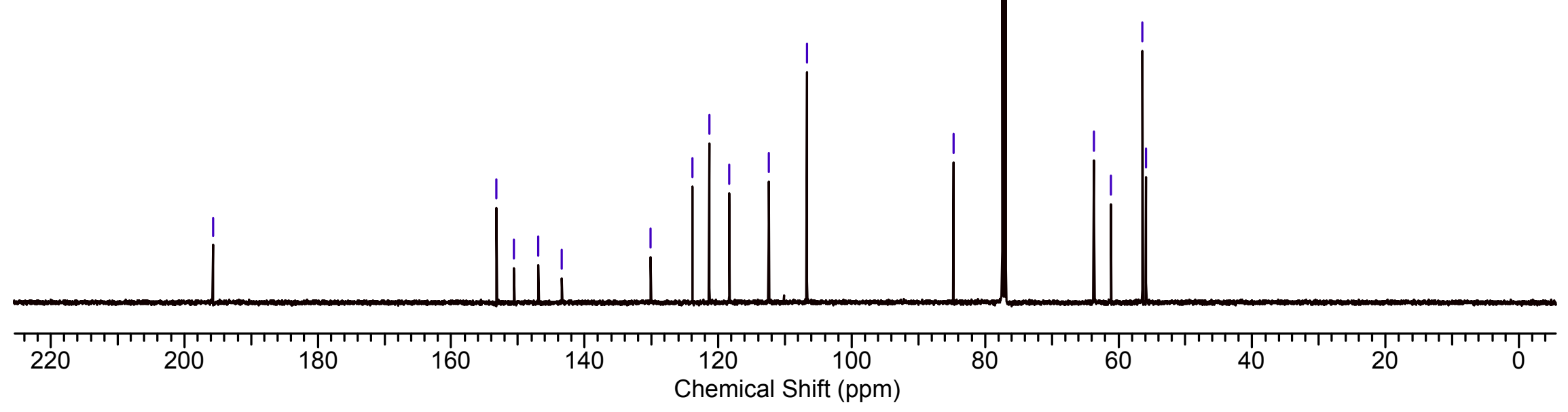


$\stackrel{\infty}{\infty}$

$\stackrel{m}{r}$

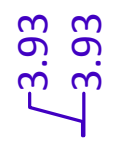

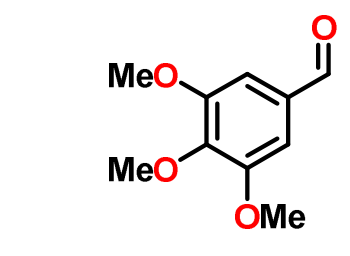

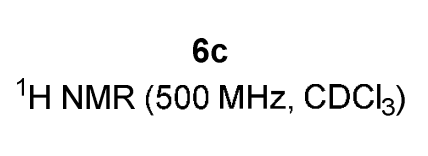

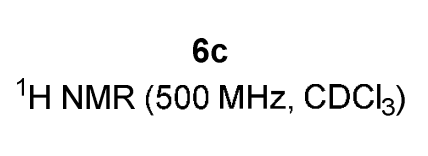

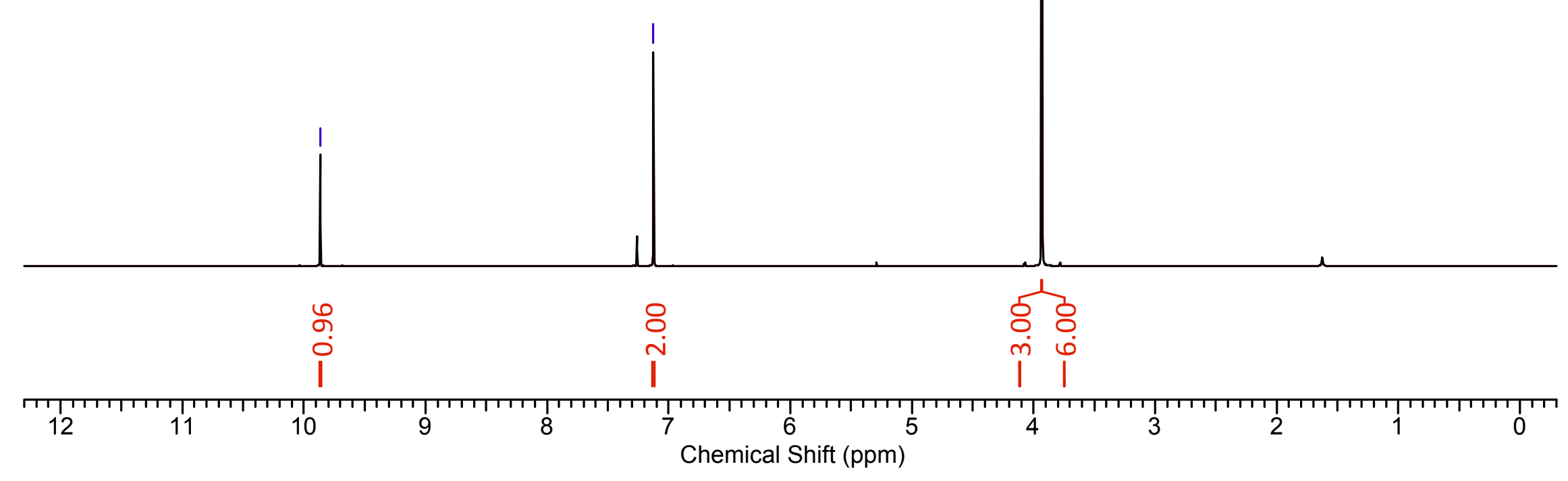

S109 


$$
\text { ำ }
$$

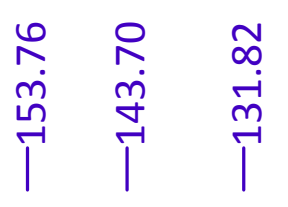

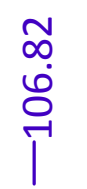

궁ㅇ

ธิن

†

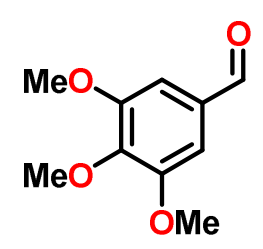

6c

${ }^{13} \mathrm{C}$ NMR (126 MHz, $\mathrm{CDCl}_{3}$ )

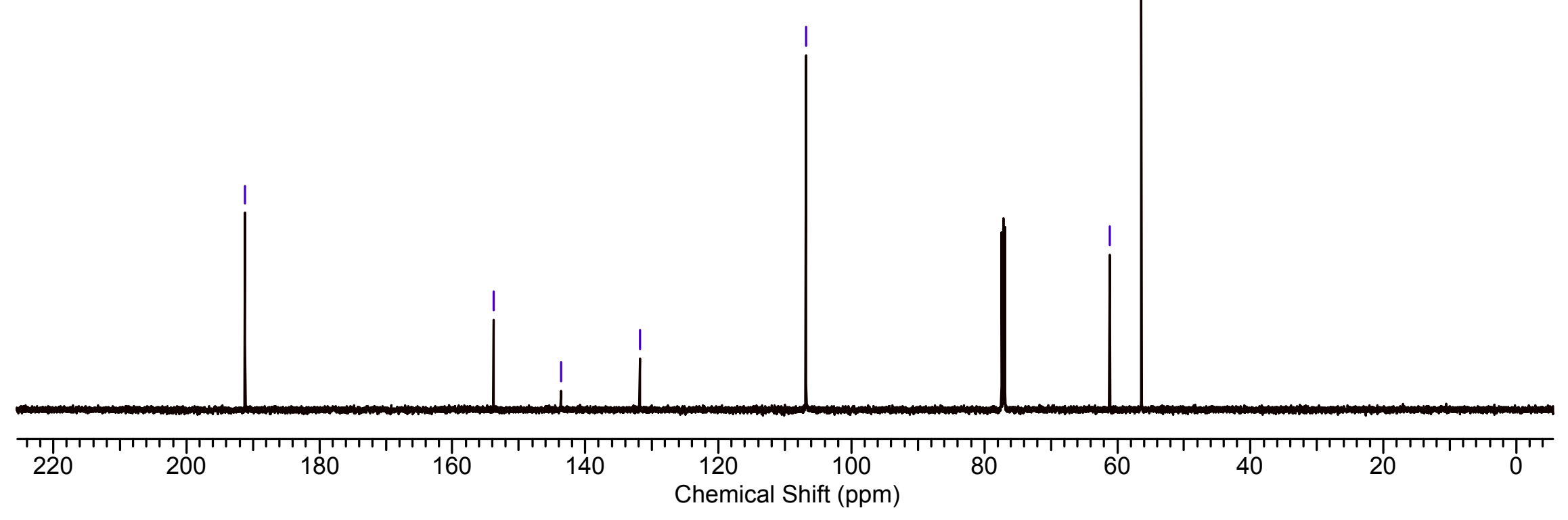




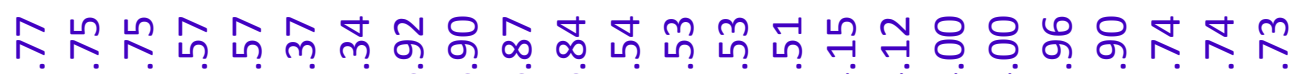

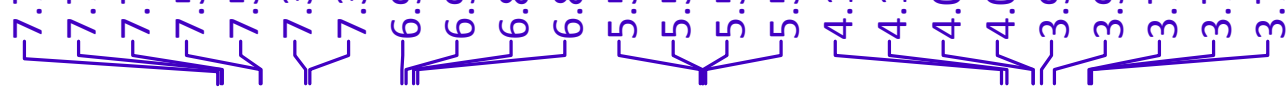

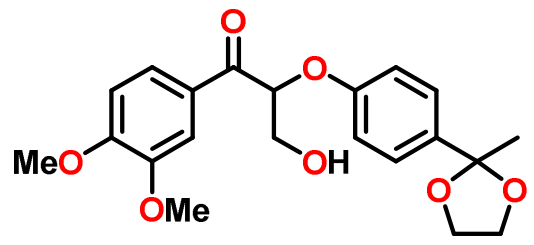

${ }^{1} \mathrm{H} \mathrm{NMR}\left(400 \mathrm{MHz}, \mathrm{CDCl}_{3}\right)$

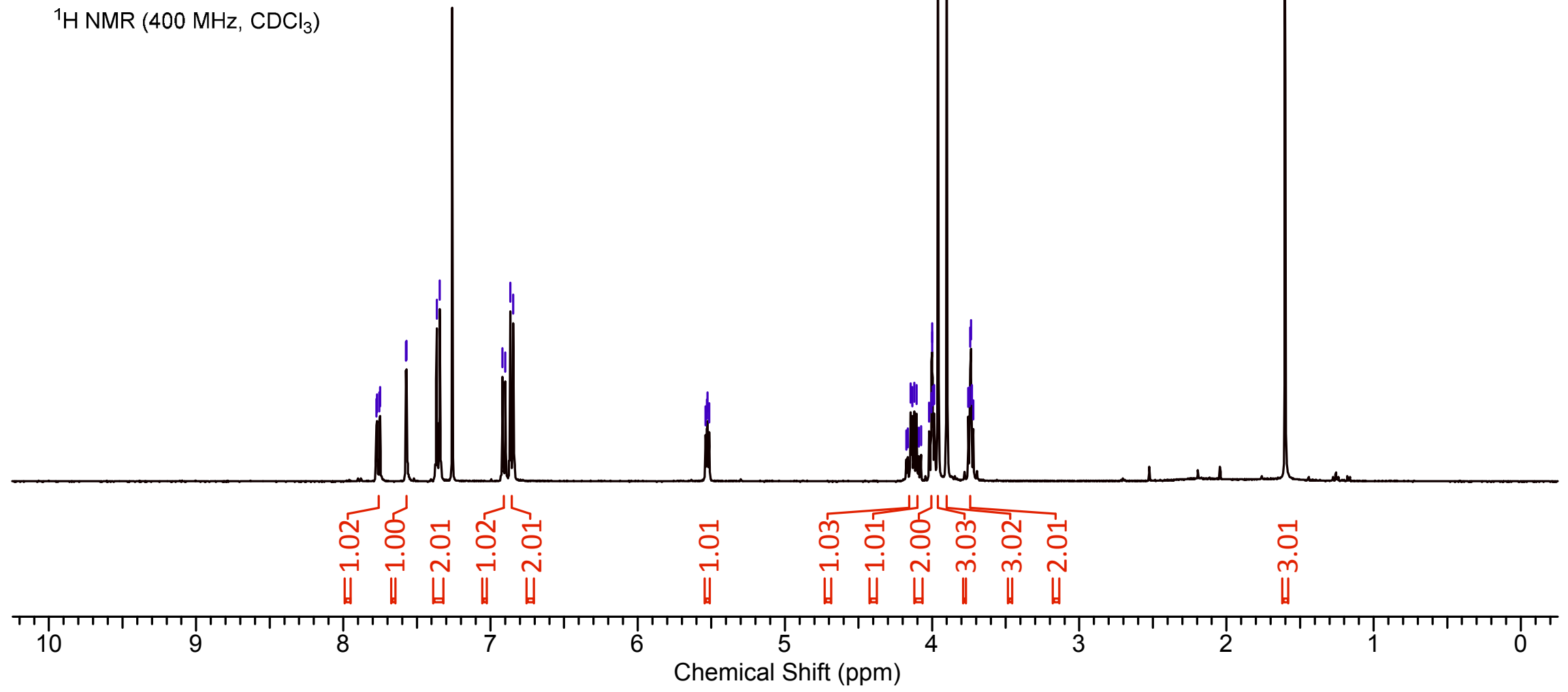




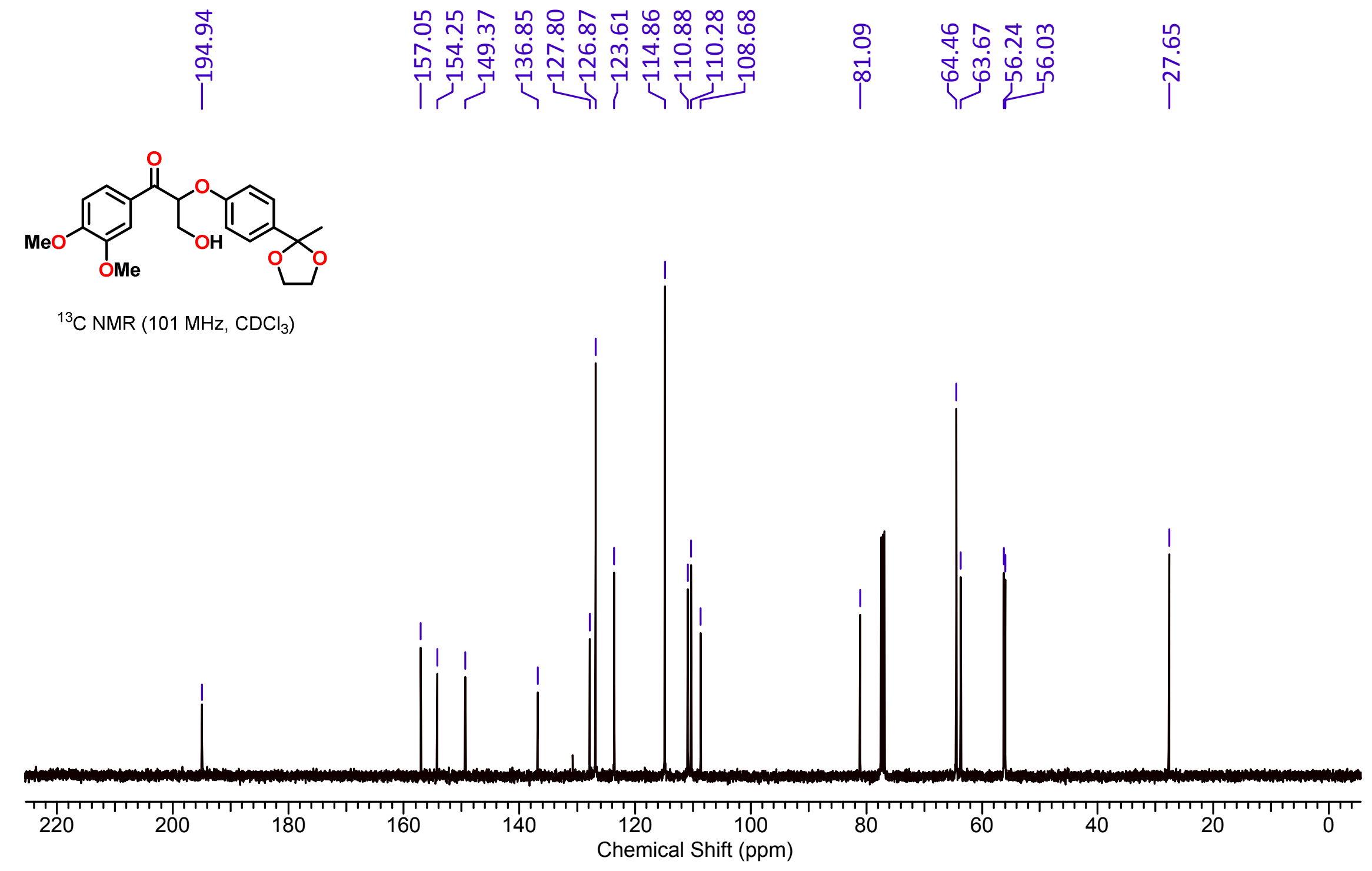




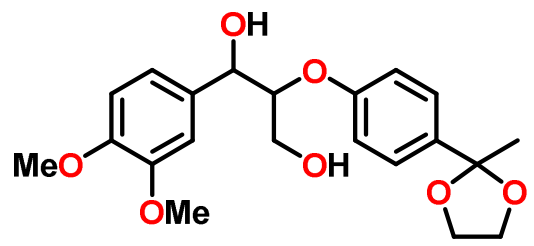

${ }^{1} \mathrm{H} \mathrm{NMR}\left(500 \mathrm{MHz}, \mathrm{CDCl}_{3}\right)$

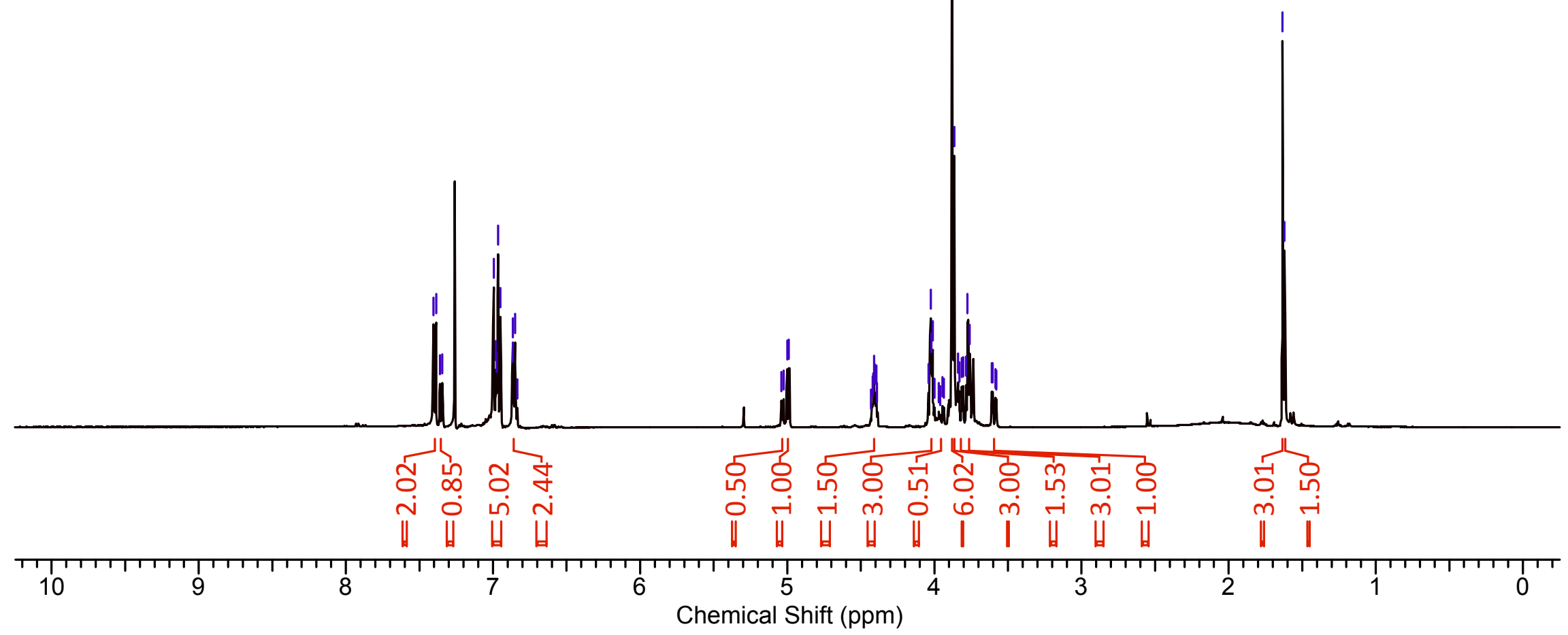




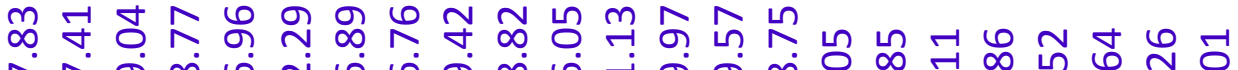

ஸें 守守

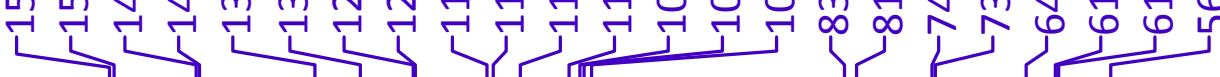

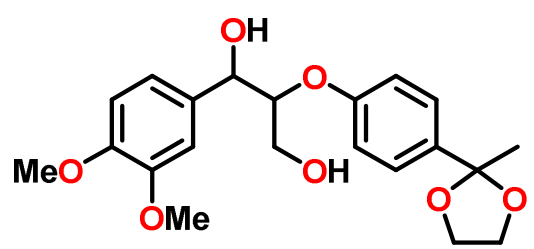

${ }^{13} \mathrm{C} \mathrm{NMR}\left(126 \mathrm{MHz}, \mathrm{CDCl}_{3}\right)$

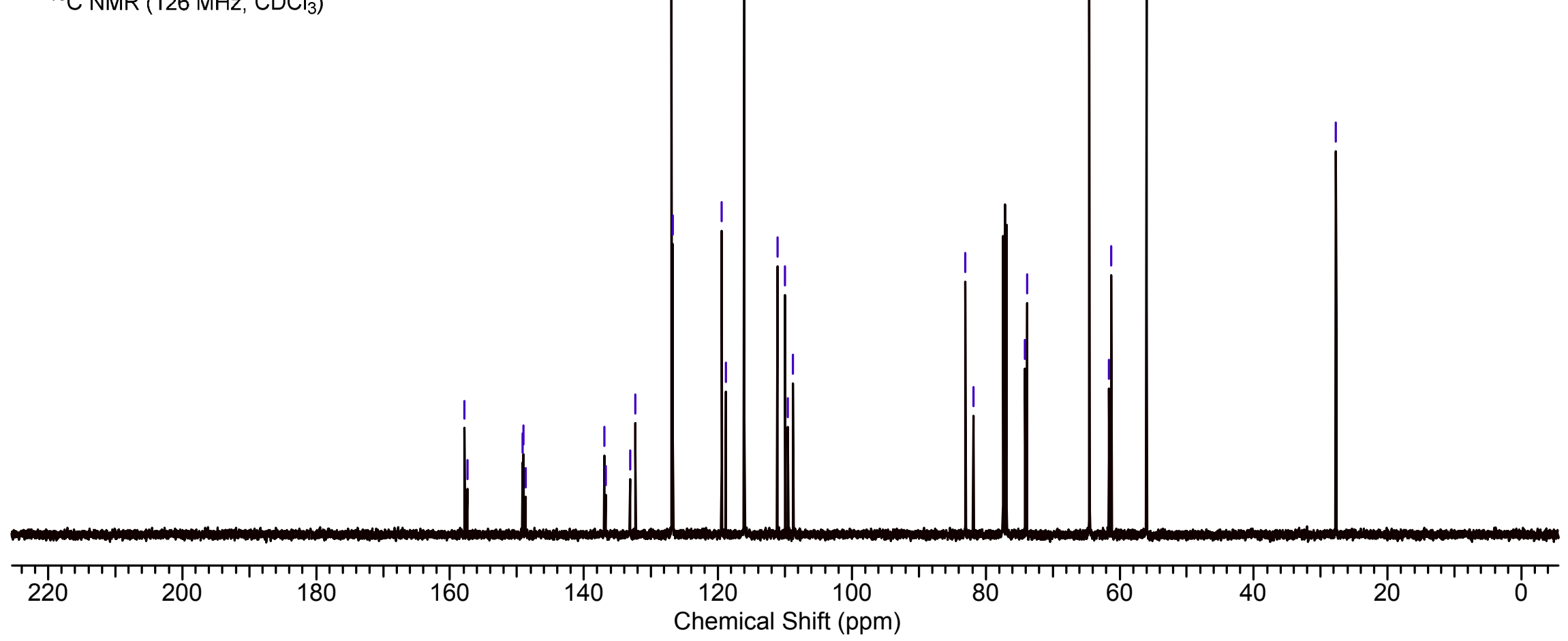




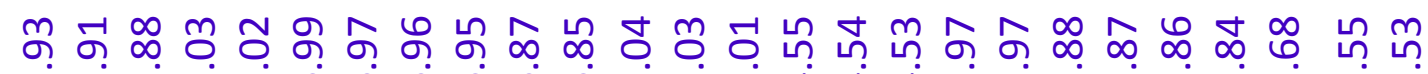

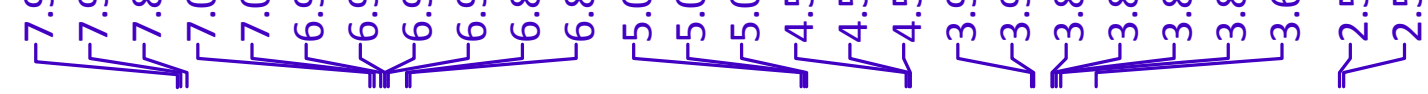

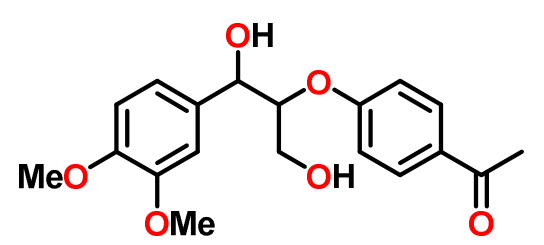

4d

${ }^{1} \mathrm{H}$ NMR $\left(500 \mathrm{MHz}, \mathrm{CDCl}_{3}\right)$

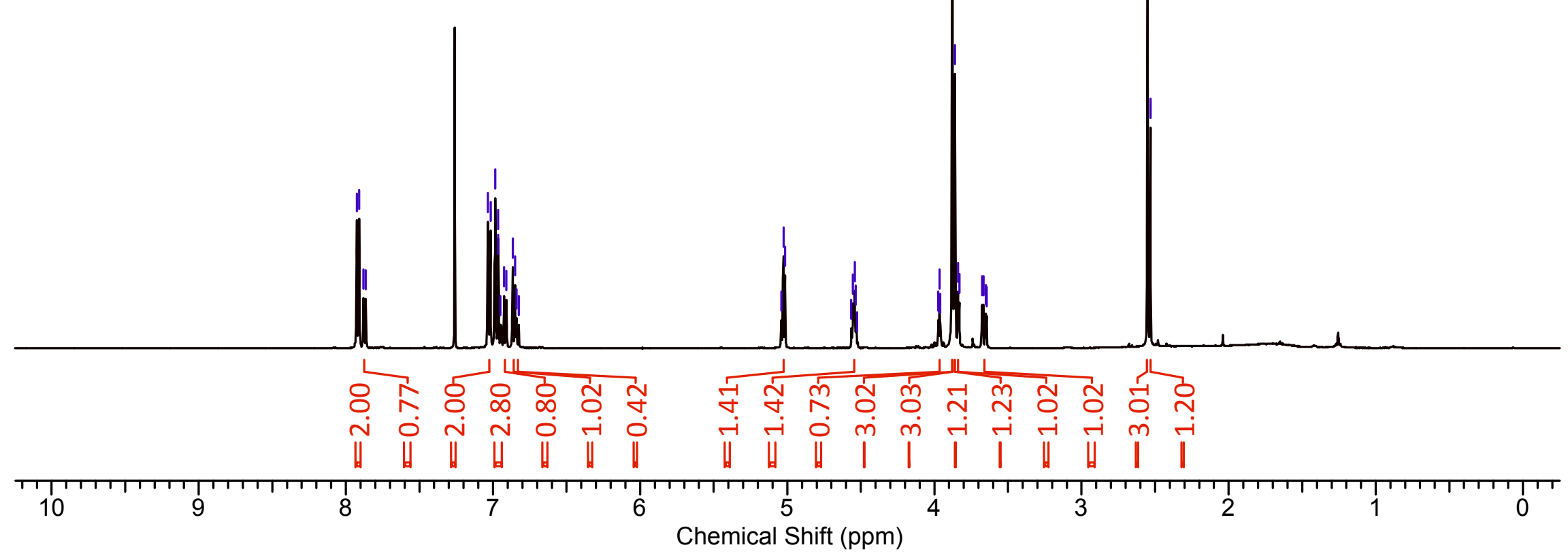




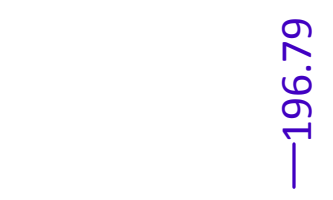

ป

ก

북

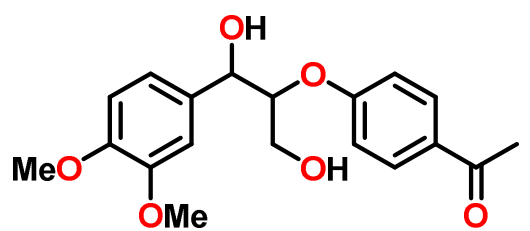

$4 d$

${ }^{13} \mathrm{C} \mathrm{NMR}\left(126 \mathrm{MHz}, \mathrm{CDCl}_{3}\right)$

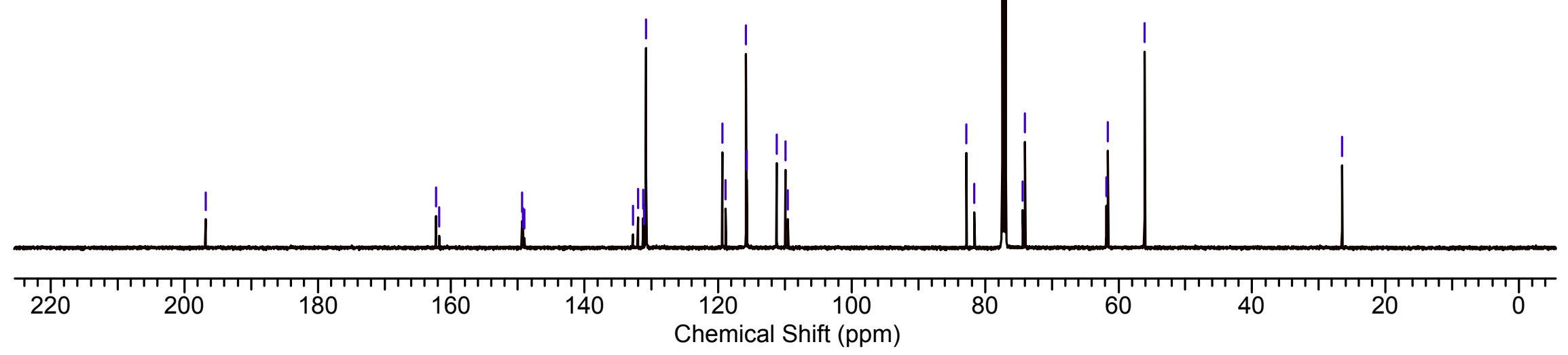




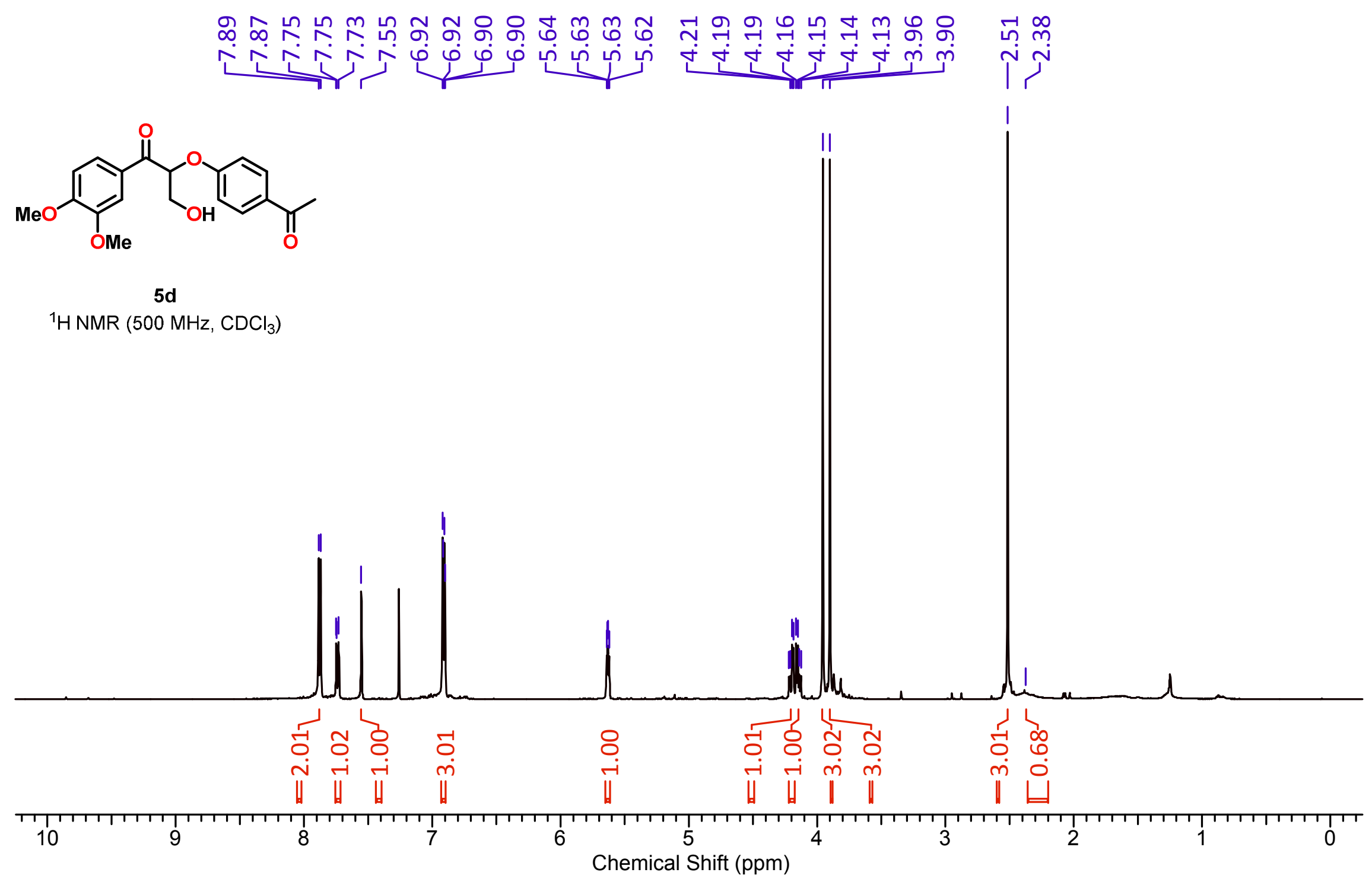



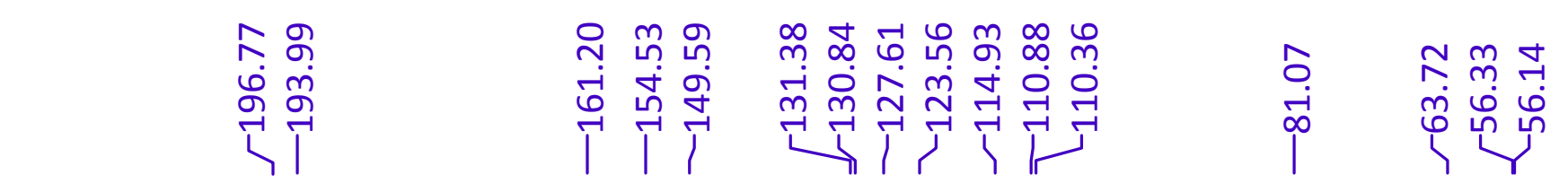

†ัণ

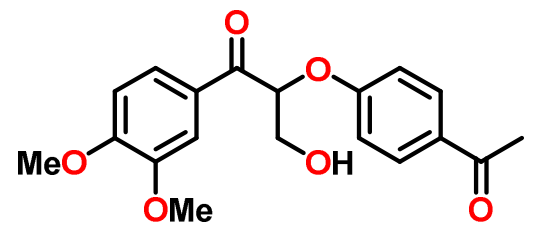

$5 d$

$\left.{ }^{13} \mathrm{C} \mathrm{NMR} \mathrm{(126} \mathrm{MHz,} \mathrm{CDCl}_{3}\right)$

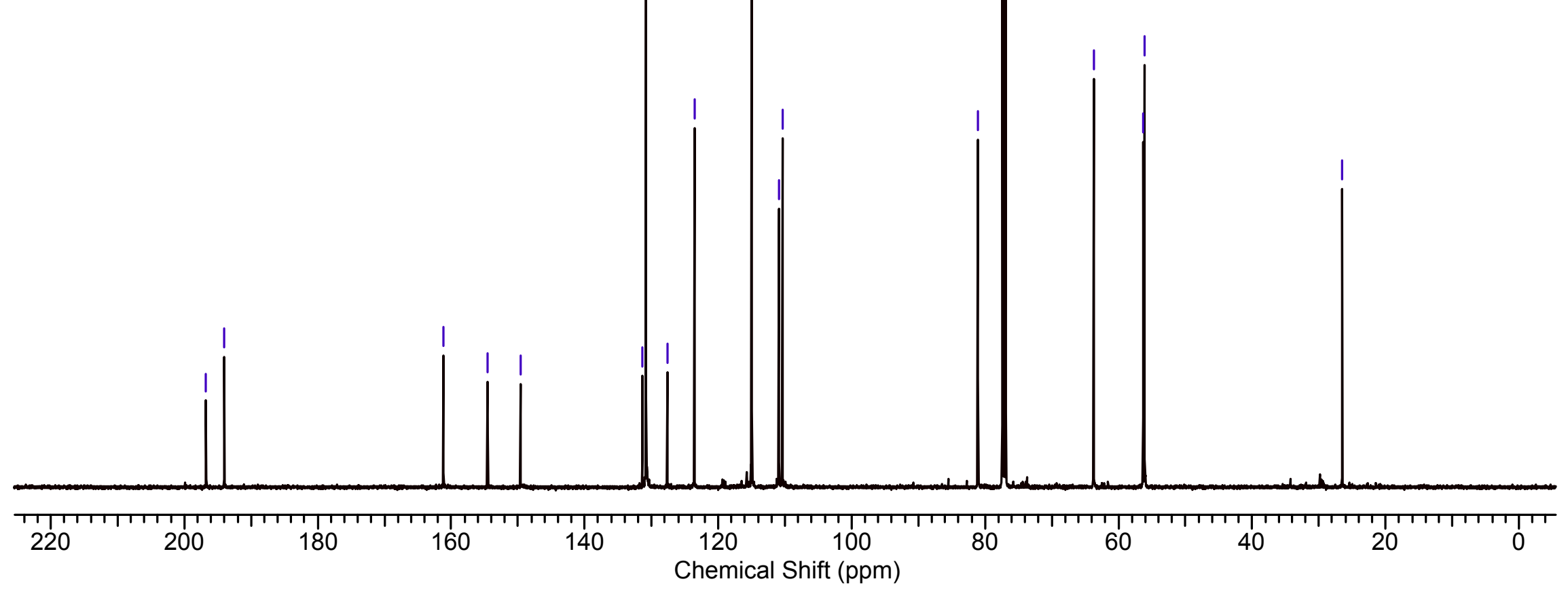



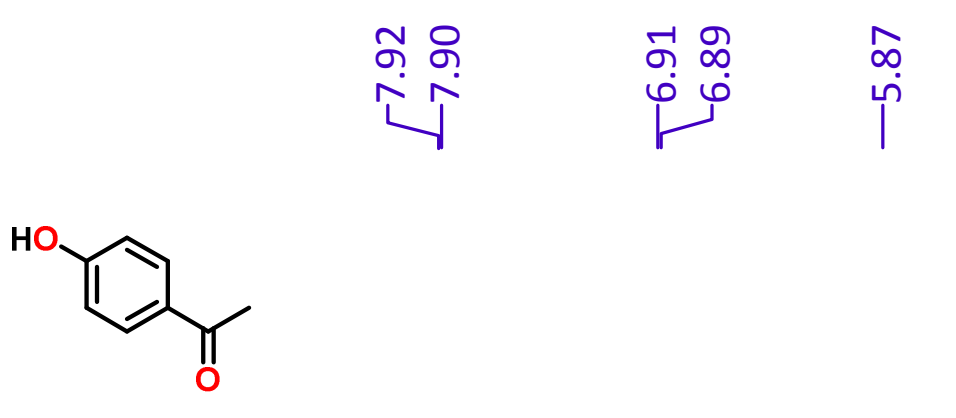

$$
7
$$

${ }^{1} \mathrm{H}$ NMR $\left(500 \mathrm{MHz}, \mathrm{CDCl}_{3}\right)$

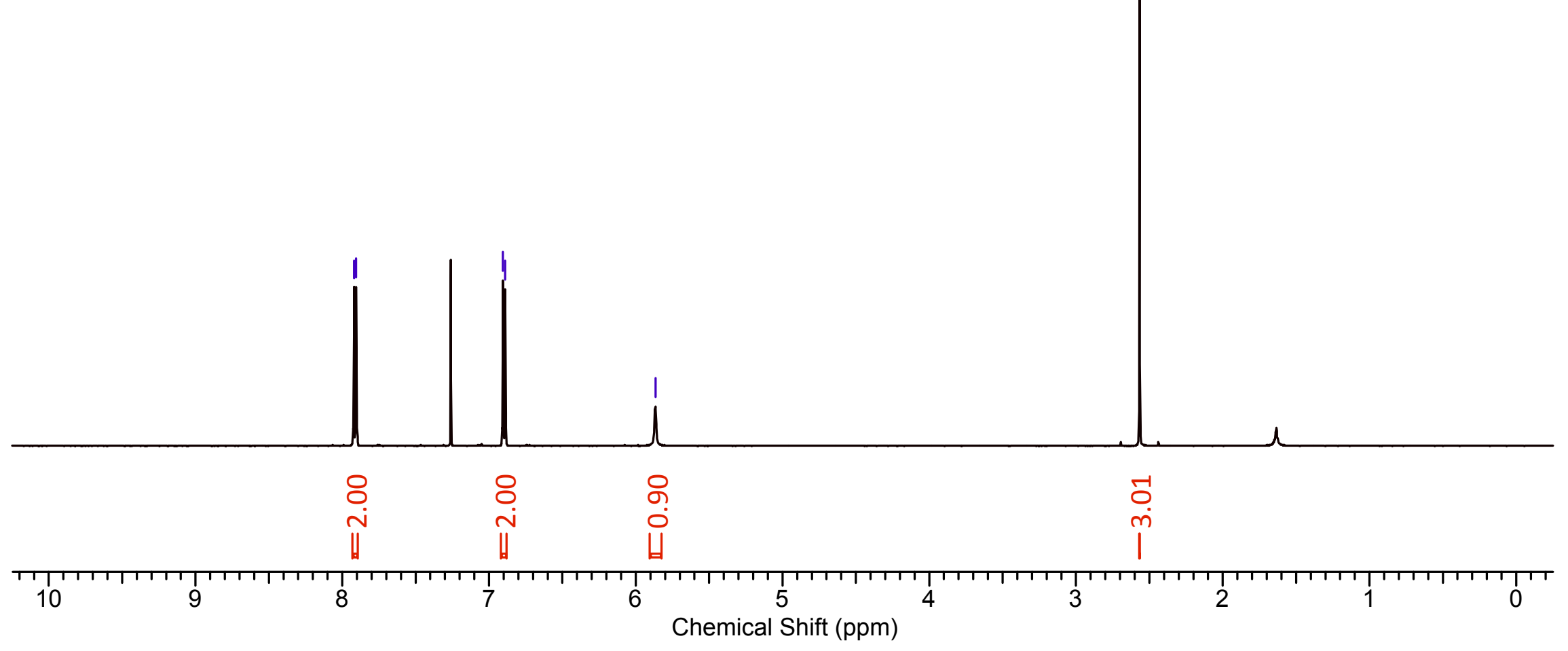




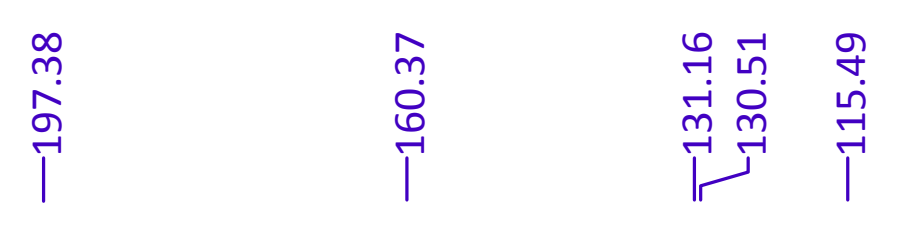

†

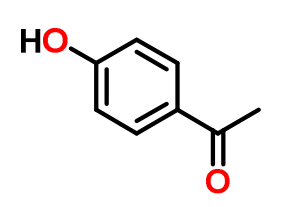

7

$\left.{ }^{13} \mathrm{C} \mathrm{NMR} \mathrm{(126} \mathrm{MHz,} \mathrm{CDCl}_{3}\right)$

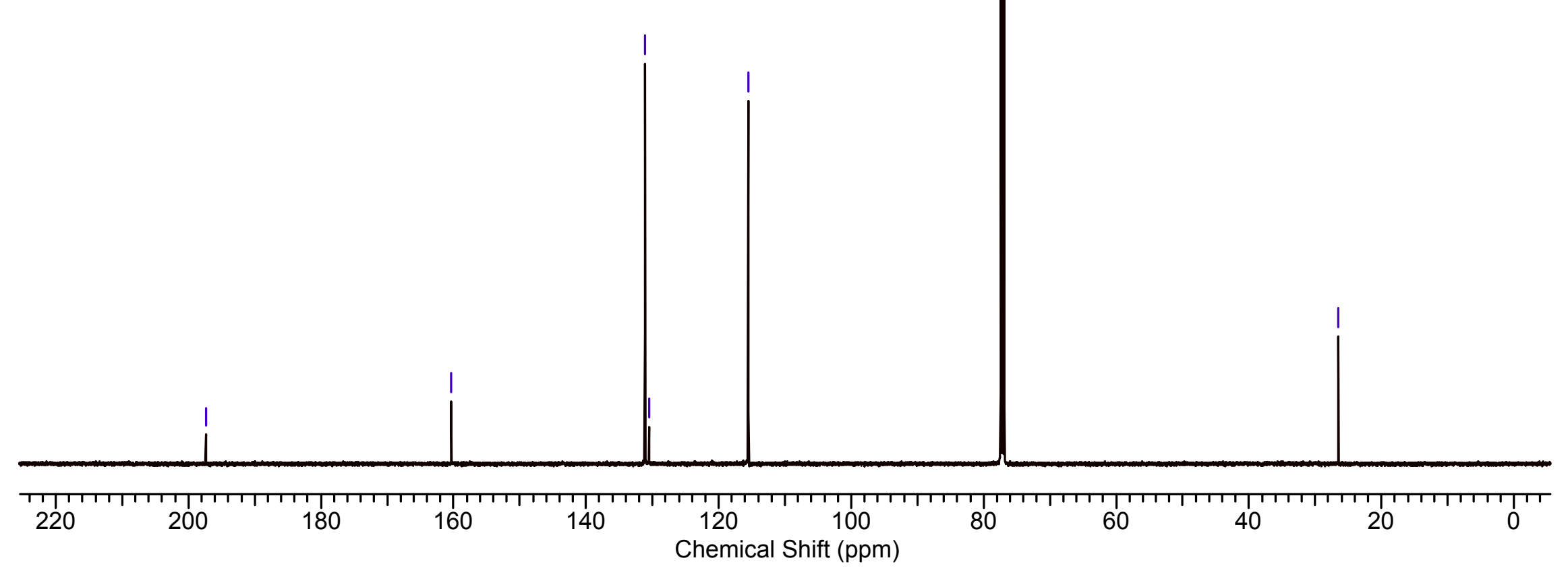




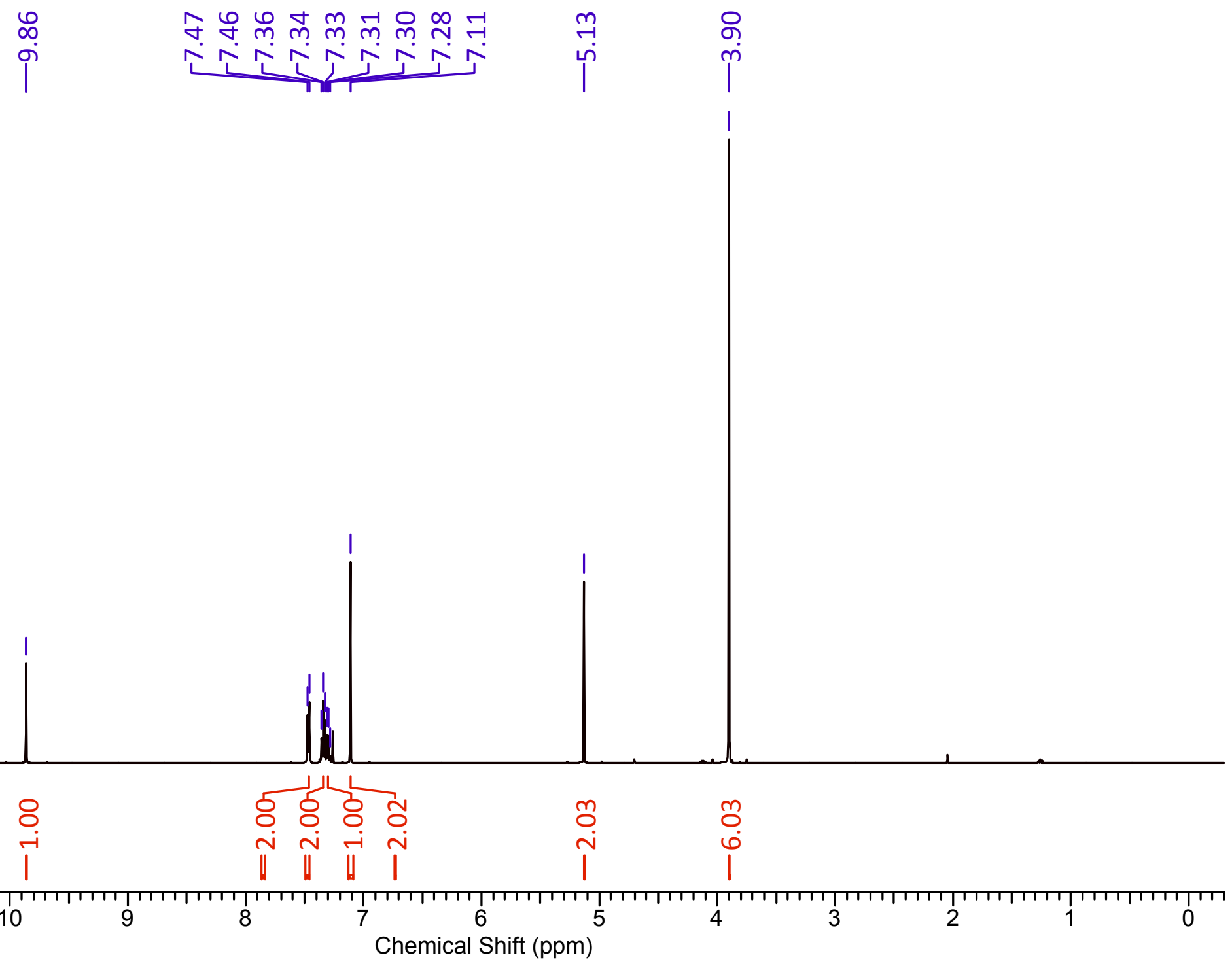



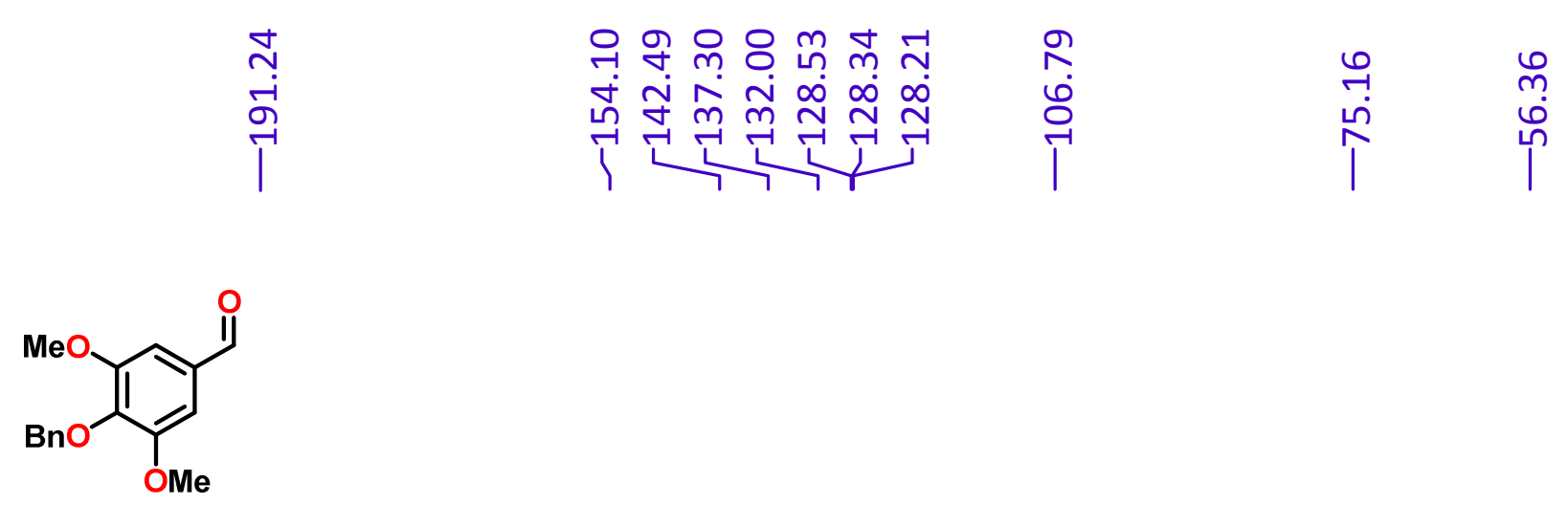

$\left.{ }^{13} \mathrm{C} \mathrm{NMR} \mathrm{(126} \mathrm{MHz,} \mathrm{CDCl}_{3}\right)$

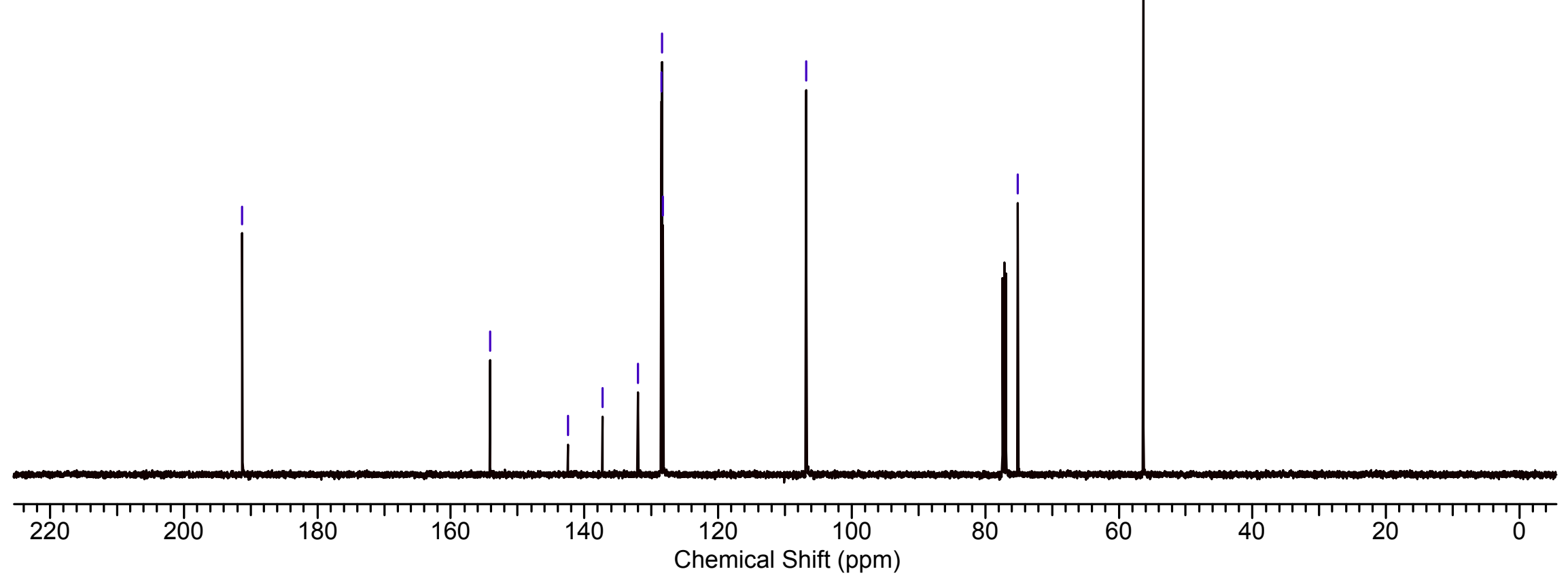




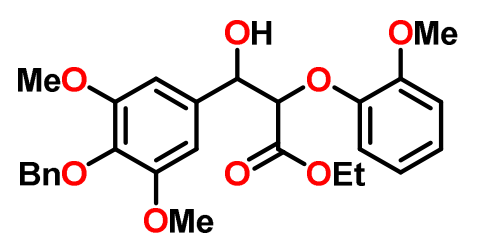

${ }^{1} \mathrm{H} \mathrm{NMR}\left(500 \mathrm{MHz}, \mathrm{CDCl}_{3}\right)$

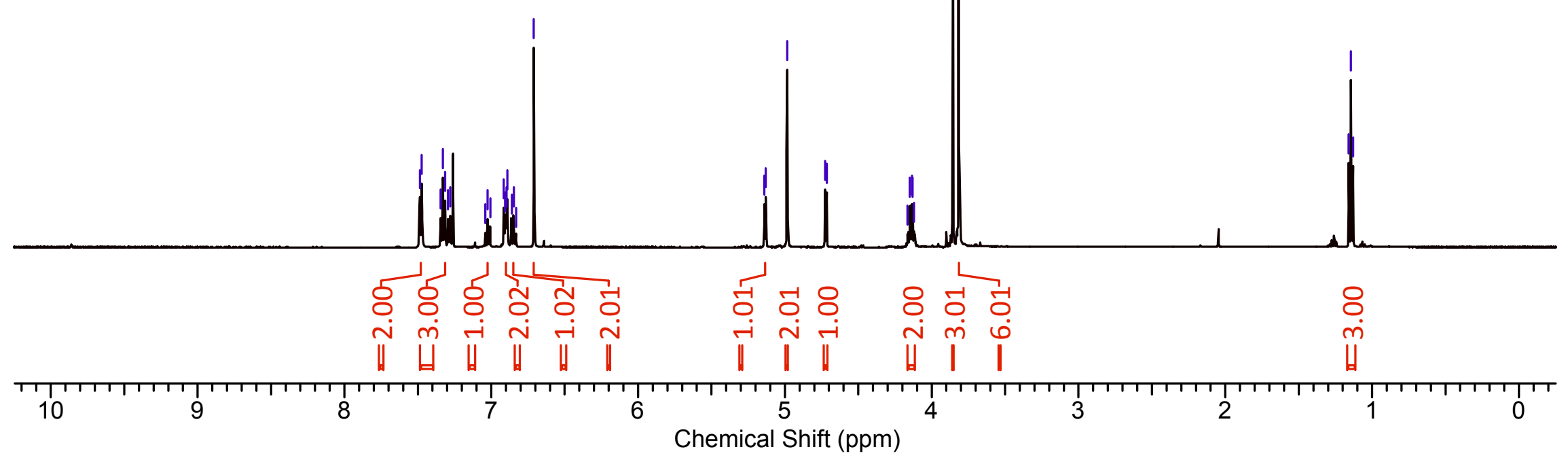



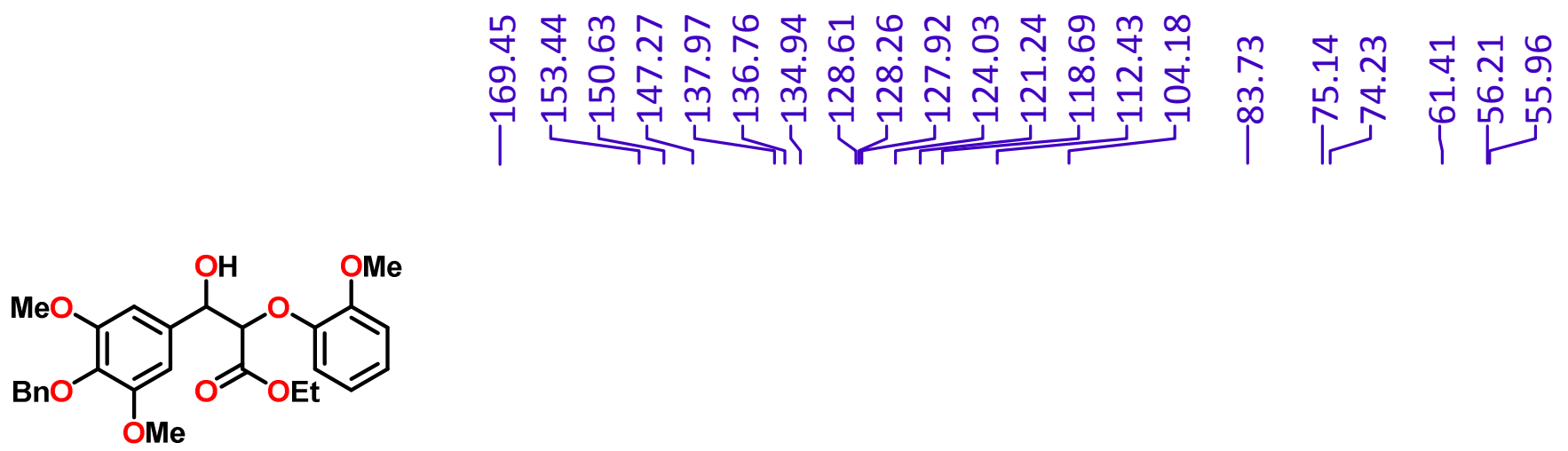

$\left.{ }^{13} \mathrm{C} \mathrm{NMR} \mathrm{(126} \mathrm{MHz,} \mathrm{CDCl}_{3}\right)$

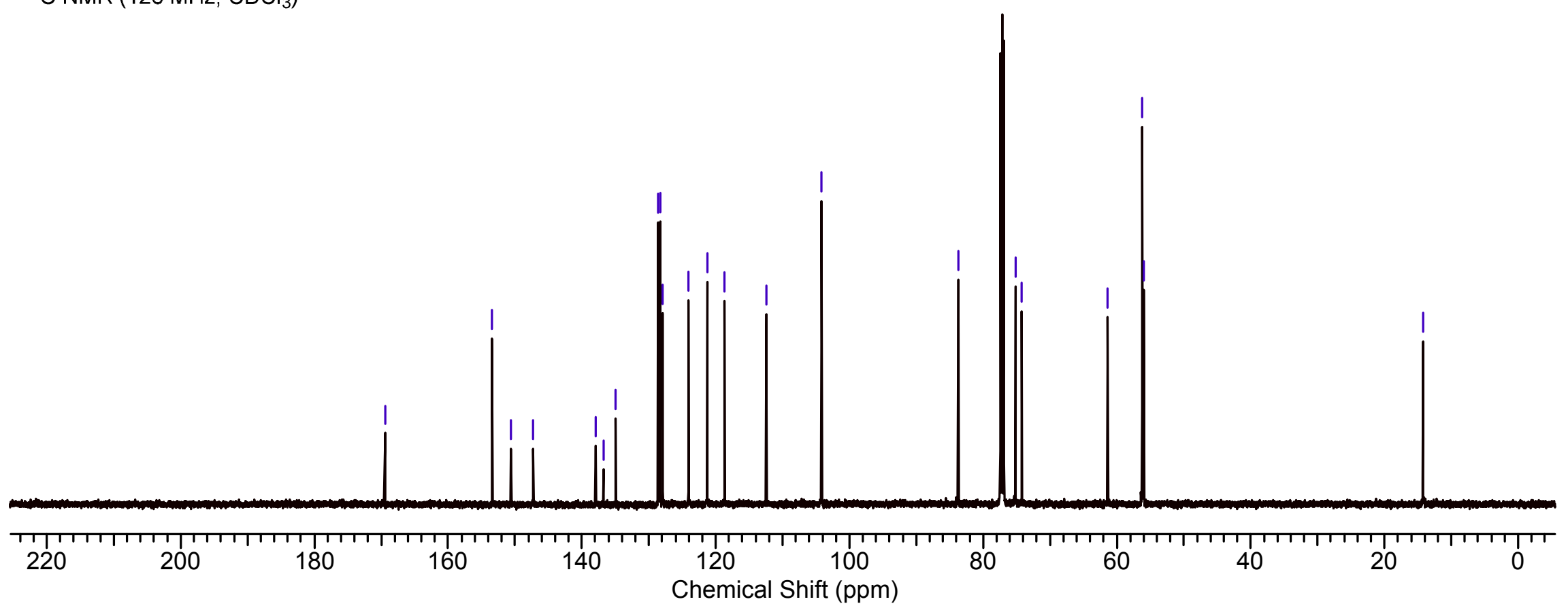




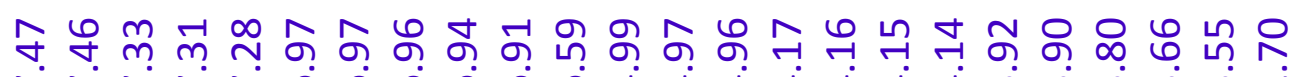

论行

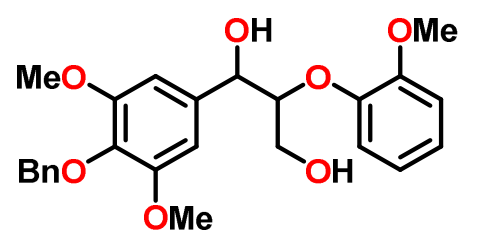

${ }^{1} \mathrm{H} \mathrm{NMR}\left(500 \mathrm{MHz}, \mathrm{CDCl}_{3}\right)$

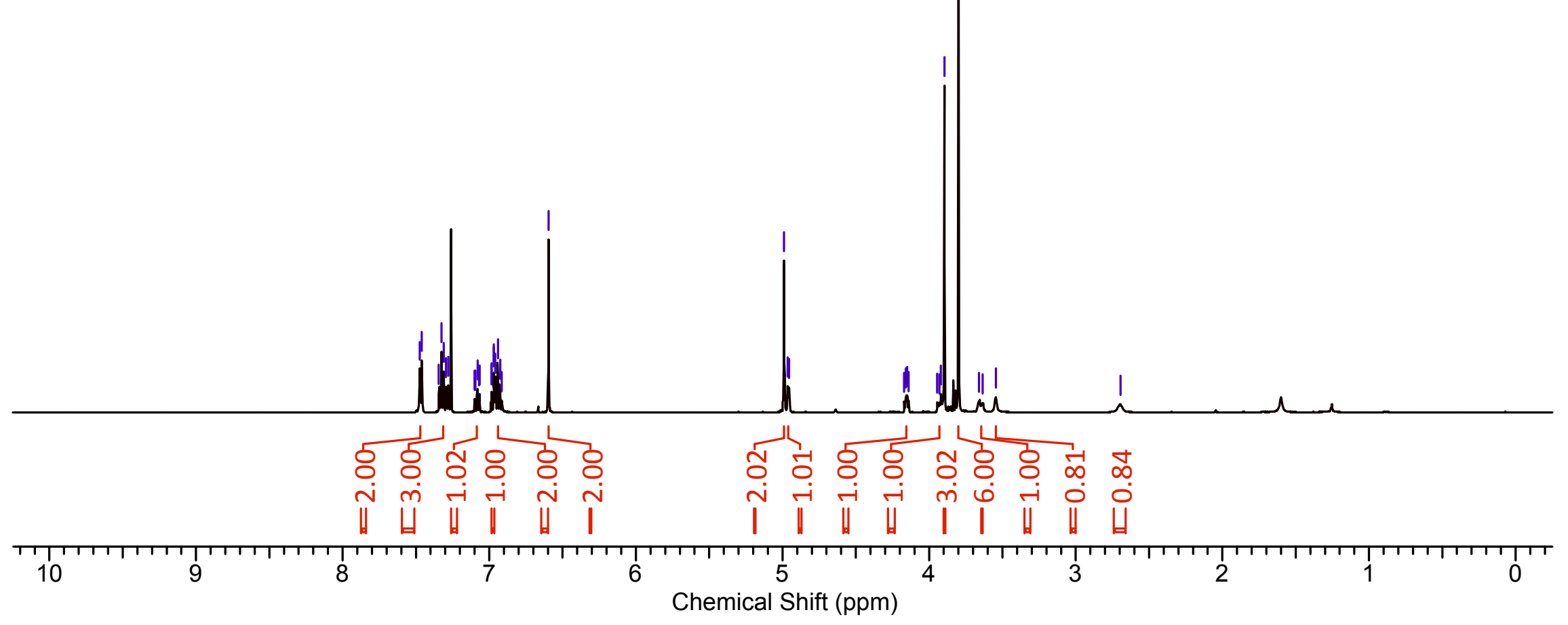



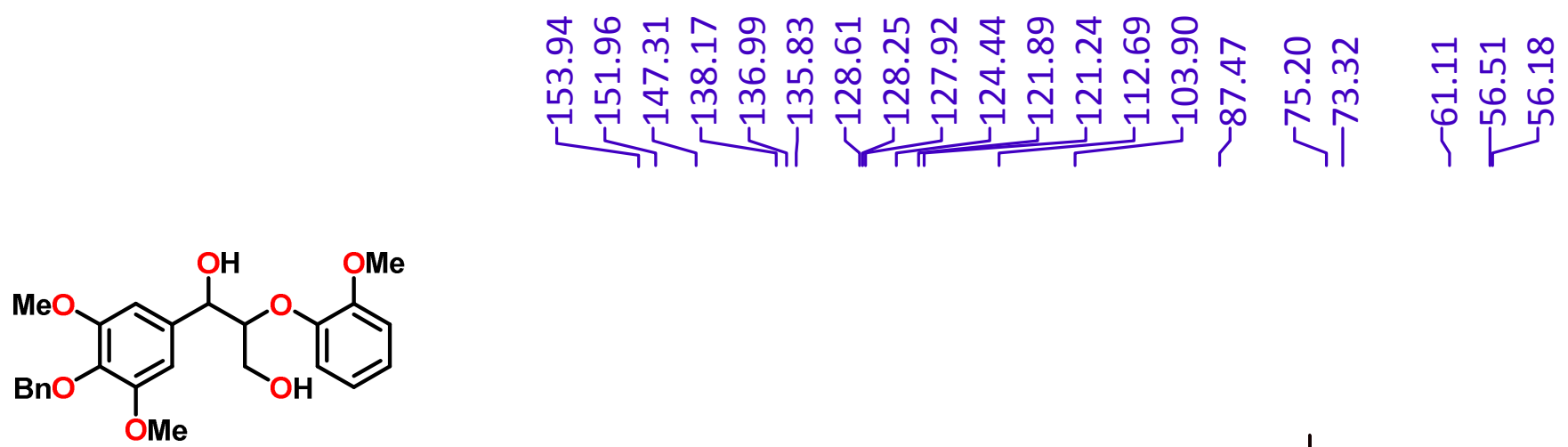

${ }^{13} \mathrm{C}$ NMR $\left(126 \mathrm{MHz}, \mathrm{CDCl}_{3}\right)$

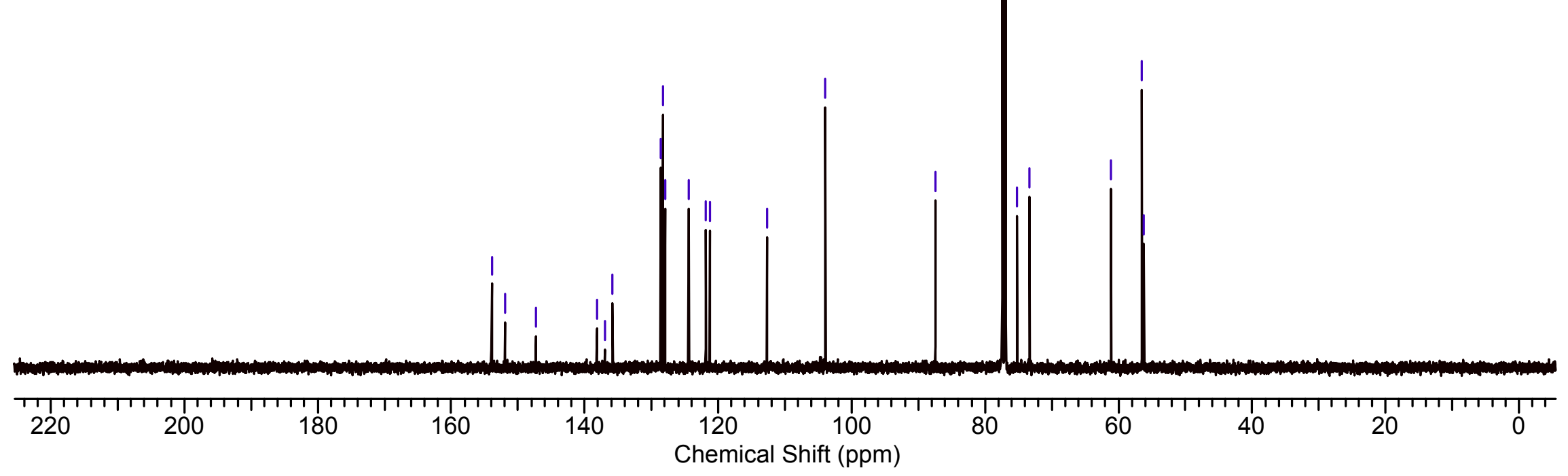


નૅ

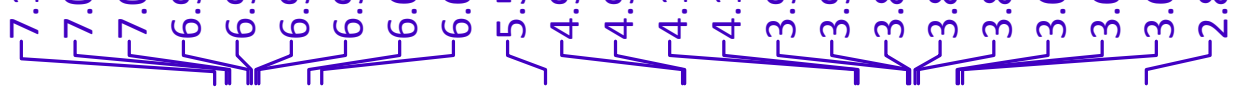

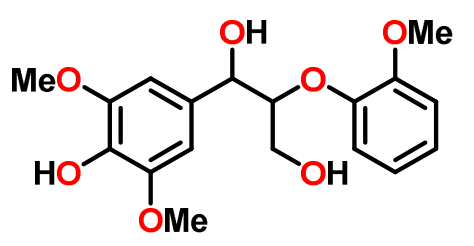

4 e

${ }^{1} \mathrm{H} \mathrm{NMR}\left(500 \mathrm{MHz}, \mathrm{CDCl}_{3}\right)$

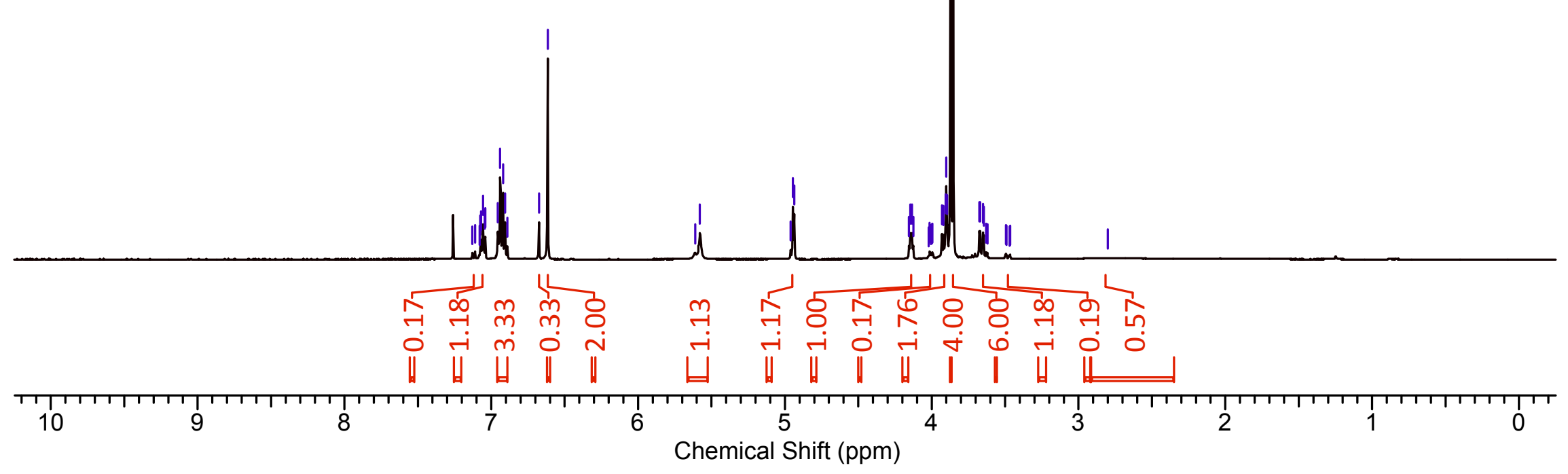




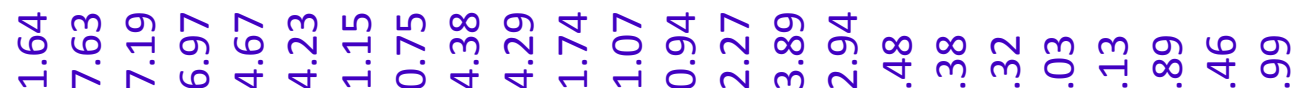

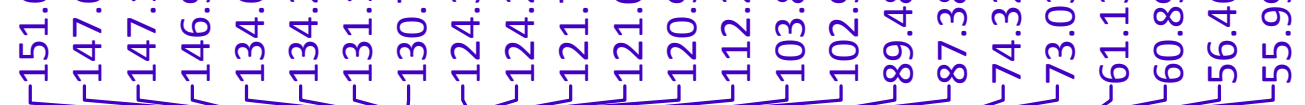

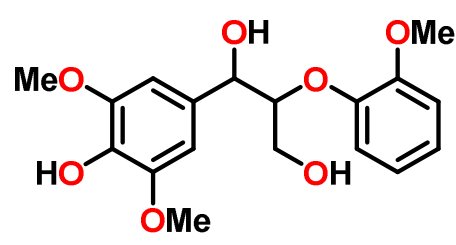

$4 e$

${ }^{13} \mathrm{C} \mathrm{NMR}\left(126 \mathrm{MHz}, \mathrm{CDCl}_{3}\right)$

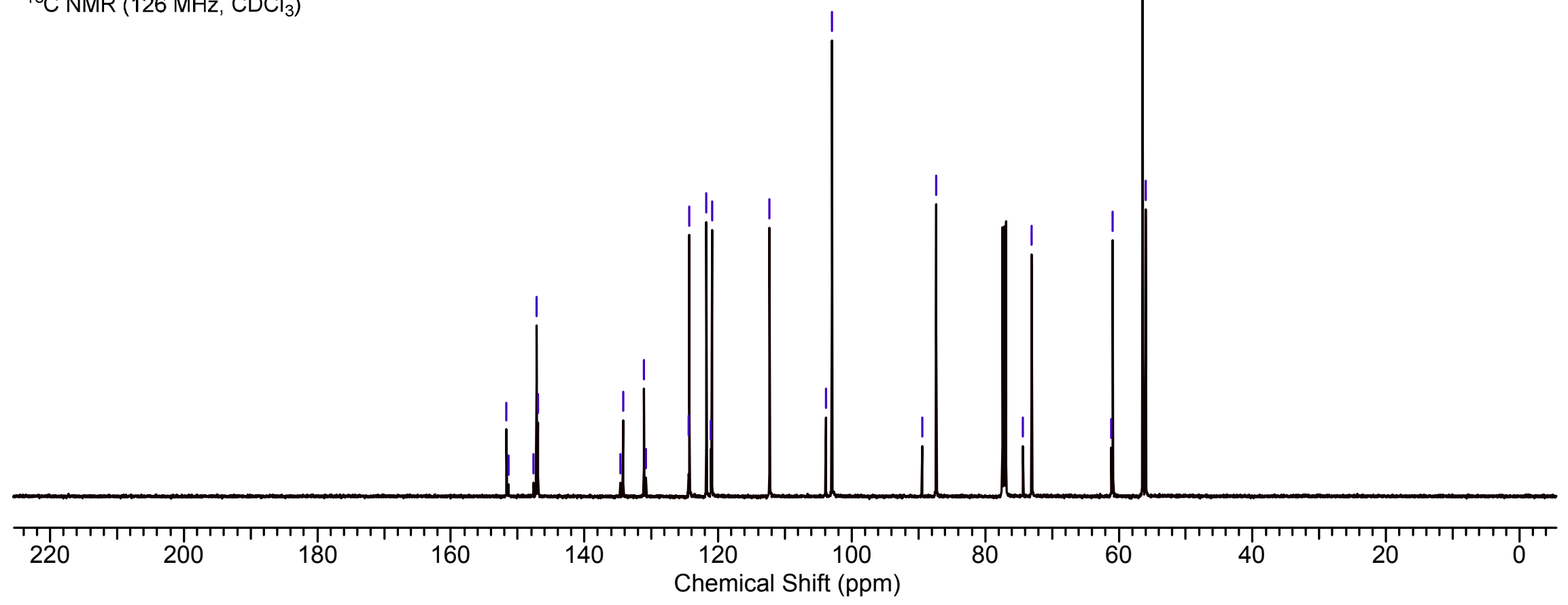



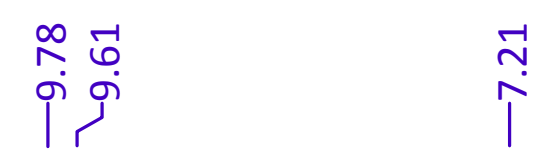

$\underset{\infty}{\infty}$

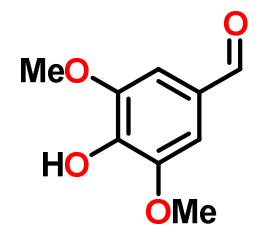

6d

${ }^{1} \mathrm{H}$ NMR $\left(500 \mathrm{MHz}\right.$, DMSO- $\left.d_{6}\right)$

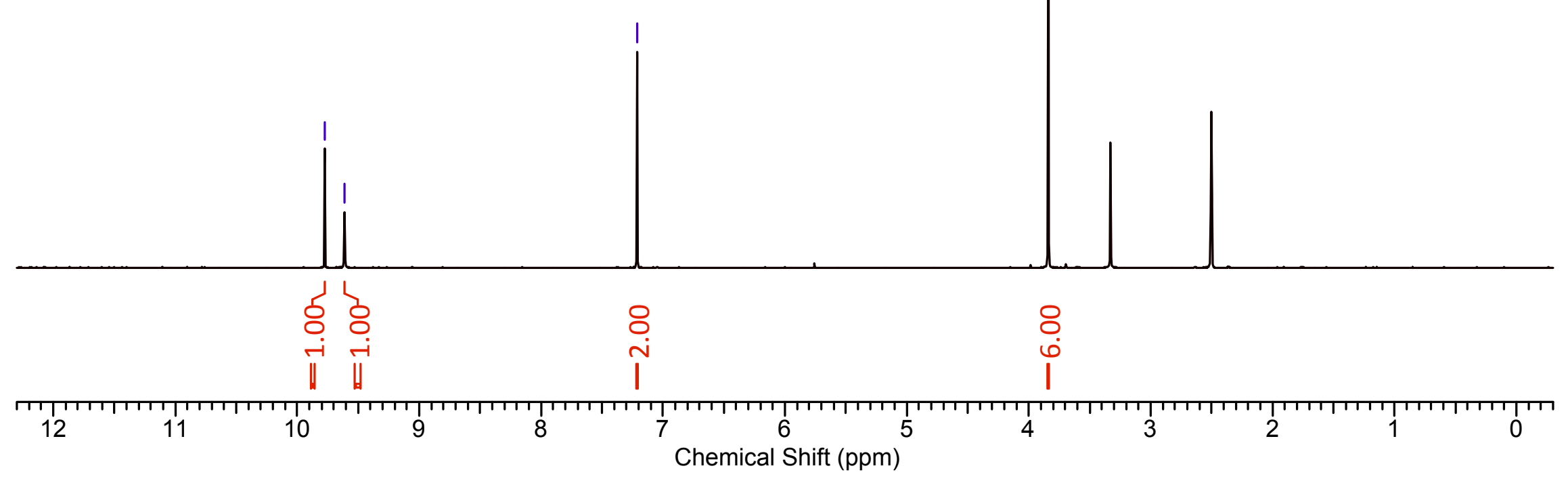



ำ

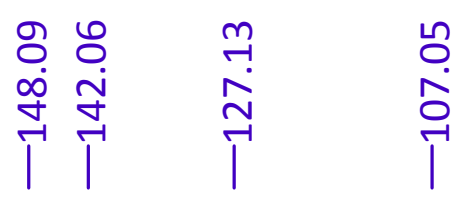
0
0
0

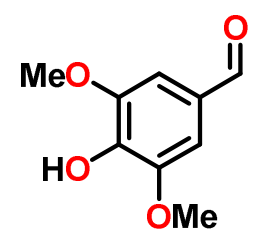

6d

${ }^{13} \mathrm{C}$ NMR $\left(126 \mathrm{MHz}\right.$, DMSO- $\left.d_{6}\right)$

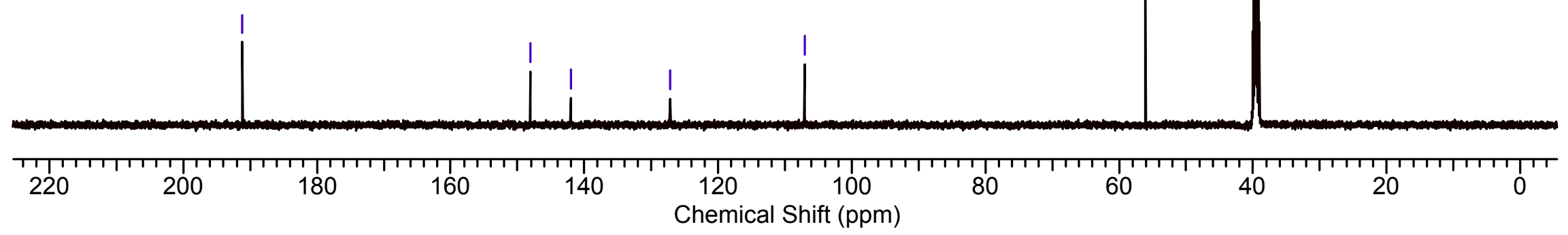




\section{Supporting References}

(S1) Galkin, M. V.; Sawadjoon, S.; Rohde, V.; Dawange, M.; Samec, J. S. M. ChemCatChem 2014, 6, $179-184$.

(S2) Picart, P.; Müller, C.; Mottweiler, J.; Wiermans, L.; Bolm, C.; Domínguez de María, P.; Schallmey, A. ChemSusChem, 2014, 7, 3164-3171.

(S3) Nichols, J. M.; Bishop, L. M.; Bergman, R. G.; Ellman, J. A. J. Am. Chem. Soc. 2010, 132, 1255412555.

(S4) Hurrell, L.; Johnston, L. J.; Mathivanan, N.; Vong, D. Can. J. Chem. 1993, 71, 1340-1348.

(S5) Rahimi, A.; Azarpira, A.; Kim, H.; Ralph, J.; Stahl, S. S. J. Am. Chem. Soc. 2013, 135, 6415-6418.

(S6) Ono, F.; Takenaka, H.; Fujikawa, T.; Mori, M.; Sato, T. Synthesis 2009, 8, 1318-1322.

(S7) Nguyen, J. D.; Matsuura, B. S.; Stephenson, C. R. J. J. Am. Chem. Soc. 2014, 136, 1218-1221.

(S8) Lim, S. H.; Nahm, K.; Ra, C. S.; Cho, D. W.; Yoon, U. C.; Latham, J. A.; Dunaway-Mariano, D.; Mariano, P. S. J. Org. Chem. 2013, 78, 9431-9443.

(S9) Zhang, G.; Wang, Y.; Wen, X.; Ding, C.; Li, Y. Chem. Commun. 2012, 48, 2979-2981.

(S10) Jiménez, F.; del Carmen Cruz, M.; Zúñiga, C.; Martínez, M. A.; Chamorro, G.; Díaz, F.; Tamariz, J. Med. Chem. Res. 2010, 19, 33-57.

(S11) Cho, D. W.; Parthasarathi, R.; Pimentel, A. S.; Maestas, G. D.; Park, H. J.; Yoon, U. C.; Dunaway-Mariano, D.; Gnanakaran, S.; Langan, P.; Mariano, P. S. J. Org. Chem. 2010, 75, $6549-6562$.

(S12) Buendia, J.; Mottweiler, J.; Bolm, C. Chem. Eur. J. 2011, 17, 13877-13882.

(S13) Lancefield, C. S.; Ojo, O. S.; Tran, F.; Westwood, N. J. Angew. Chem. Int. Ed. 2015, 54, 258262.

(S14) Chen, C.; Liu, B.; Chen, W. Synthesis 2013, 45, 3387-3391.

(S15) Jeena, V.; Robinson, R. S. Chem. Commun. 2012, 48, 299-301.

(S16) Gooßen, L. J.; Khan, B. A.; Fett, T.; Treu, M. Adv. Synth. Catal. 2010, 352, 2166-2170. 
(S17) Amancha, P. K.; Liu, H.-J.; Ly, T. W.; Shia, K.-S. Eur. J. Org. Chem. 2010, 3473-3480.

(S18) Kim, H.; Ralph, J.; Lu, F.; Pilate, G.; Leplé, J.-C.; Pollet, B.; Lapierre, C. J. Biol. Chem. 2002, 277, 47412-47419.

(S19) Pardini, V. L.; Smith, C. Z.; Utley, J. H. P.; Vargas, R. R.; Viertler, H. J. Org. Chem. 1991, 56, $7305-7313$.

(S20) Hanson, S. K.; Wu, R.; Silks, L. A. Angew. Chem. Int. Ed. 2012, 51, 3410-3413.

(S21) Yi, B.; Hu, L.; Mei, W.; Zhou, K.; Wang, H.; Luo, Y.; Wei, X.; Dai H. Molecules 2010, 16, 1015710167.

(S22) Stern, O.; Volmer, M. Physik. Zeitschr. 1919, 20, 183-188.

(S23) Lowry, M. S.; Goldsmith, J. I.; Slinker, J. D.; Rohl, R.; Pascal, Jr., R. A.; Malliaras, G. G.; Bernhard, S. Chem. Mater. 2005, 17, 5712-5719.

(S24) (a) Widegren, J. A.; Finke, R. G. J. Mol. Catal. A: Chem. 2003, 198, 317-341. (b) Crabtree, R. H. Chem. Rev. 2011, 112, 1536-1554. 